\title{
THERMODYNAMIC MODELING OF THE SRS EVAPORATORS: PART I. THE 2H AND 2F SYSTEMS (U)
}

C. M. Jantzen, J. E. Laurinat, and K.G. Brown

April 4, 2002

TTP \#: SR-1-9-WT-31, Subtask A.2-2

Approved by:

W.L. Tamosaitis, Research Manager

Waste Processing Technology

Westinghouse Savannah River Company

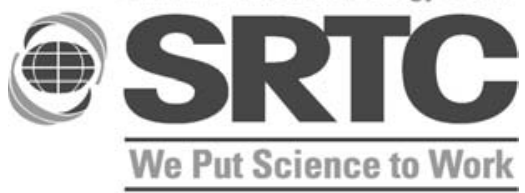

PREPARED FOR THE U.S. DEPARTMENT OF ENERGY UNDER CONTRACT NO. DE-AC09-96SR18500 
This document was prepared in conjunction with work accomplished under Contract No. DE-AC09-96SR18500 with the U. S. Department of Energy.

\section{DISCLAIMER}

This report was prepared as an account of work sponsored by an agency of the United States Government. Neither the United States Government nor any agency thereof, nor any of their employees, makes any warranty, express or implied, or assumes any legal liability or responsibility for the accuracy, completeness, or usefulness of any information, apparatus, product or process disclosed, or represents that its use would not infringe privately owned rights. Reference herein to any specific commercial product, process or service by trade name, trademark, manufacturer, or otherwise does not necessarily constitute or imply its endorsement, recommendation, or favoring by the United States Government or any agency thereof. The views and opinions of authors expressed herein do not necessarily state or reflect those of the United States Government or any agency thereof.

This report has been reproduced directly from the best available copy.

Available for sale to the public, in paper, from: U.S. Department of Commerce, National Technical Information Service, 5285 Port Royal Road, Springfield, VA 22161, phone: (800) 553-6847, fax: (703) 605-6900

email: orders@ ntis.fedworld.gov

online ordering: http://www.ntis.gov/support/index.html

Available electronically at http://www.osti.gov/bridge

Available for a processing fee to U.S. Department of Energy and its contractors, in paper, from: U.S. Department of Energy, Office of Scientific and Technical Information, P.O. Box 62, Oak Ridge, TN 37831-0062,

phone: (865)576-8401,

fax: (865)576-5728

email: $\underline{\text { reports@ adonis.osti.gov }}$ 
WSRC-TR-2000-00293, Rev. 1

WSRC-TR-2000-00293, Rev. 1

Distribution Category: Unlimited

Keywords: Evaporator, activity diagrams, zeolite

Retention: Permanent

\section{THERMODYNAMIC MODELING OF THE SRS EVAPORATORS: PART I. THE 2H AND 2F SYSTEMS (U)}

C. M. Jantzen, J. E. Laurinat, and K.G. Brown

Publication Date: April 4, 2002

Westinghouse Savannah River Company

Savannah River Site

Aiken, SC 29808
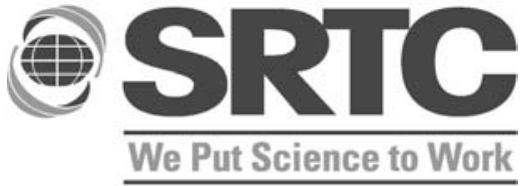

PREPARED FOR THE U.S. DEPARTMENT OF ENERGY UNDER CONTRACT NO. DE-AC09-96SR18500 


\section{Approvals}

C. M. Jantzen, Author, Immobilization Technology

Date

J. E. Laurinat, Author, Actinide Technology

Date

K.G. Brown, Author, Immobilization Technology

Date

M. E. Denham, Technical Reviewer, Environ. Sci. \& Technology Date

$\overline{\text { D.T. Hobbs, Technical Reviewer, Waste Processing Technology }}$

Date

J. F. Ortaldo, Technical Reviewer, WD Engineering

Date

J. L. England, Technical Reviewer, CST Engineering

Date

R.H. Spires, Manager, Immobilization Technology

Date

A. M. Murray, Manager, Actinide Technology

Date

W.L. Tamosaitis, Manager, Waste Processing Technology

Date 


\section{WSRC-TR-2000-00293, Rev. 1}

\section{EXECUTIVE SUMMARY}

Accumulations of two solid phases (a nitrated aluminosilicate, known as nitrated cancrinite and/or nitrated sodalite depending on the crystal structure and the number of attached water molecules, e.g. $\mathrm{Na}_{8} \mathrm{Al}_{6} \mathrm{Si}_{6} \mathrm{O}_{24}\left(\mathrm{NO}_{3}\right)_{2} \bullet 4 \mathrm{H}_{2} \mathrm{O}$, and sodium diuranate, $\mathrm{Na}_{2} \mathrm{U}_{2} \mathrm{O}_{7}$ ) have occurred in the Savannah River Site (SRS) 2H-Evaporator system since late 1996. The aluminosilicate scale deposits caused the SRS 2H-Evaporator to become completely inoperable in October 1999. Accumulation of the sodium diuranate phase, which appears to have simultaneously precipitated with the aluminosilicate phase, has caused criticality concerns in the $2 \mathrm{H}$-Evaporator. Analysis of the deposits indicated that amorphous aluminate phase may be involved in causing the deposits to form and adhere. A mechanism by which crystalline $\mathrm{Al}(\mathrm{OH})_{3}$ was found adhering to the walls of waste tanks in the SRS M-Area is suggested. The evaporator has been cleaned. A method of controlling the process chemistry is developed in this study to prevent the formation of aluminosilicate deposits in the future.

Reactive oxides, soluble silicates, and soluble aluminates in caustic solution can combine to form a sodium aluminosilicate (NAS) hydrogel at ambient temperature when the solution stoichiometry of the constituent aluminate and silicate species is $\sim 1: 1$. The hydrogel converts to Zeolite- $\mathrm{A}\left(\mathrm{Na}_{12} \mathrm{Al}_{12} \mathrm{Si}_{12} \mathrm{O}_{48} \bullet 27 \mathrm{H}_{2} \mathrm{O}\right)$ under hydrothermal conditions at elevated temperature such as the conditions existing in the SRS evaporators. It has been shown that the nitrated-cancrinite/sodalite forming in the SRS 2H-Evaporator forms from Zeolite-A. Zeolite-A and hydroxysodalite $\left(\mathrm{Na}_{8}\left[\mathrm{Al}_{6} \mathrm{Si}_{6} \mathrm{O}_{24}\right](\mathrm{OH})_{2} \bullet 1.5 \mathrm{H}_{2} \mathrm{O}\right)$ formation from a gel phase has also been observed in evaporators used in the wood pulp industry and Zeolite- $\mathrm{A} \rightarrow$ sodalite $\rightarrow$ cancrinite $\left(\left(\mathrm{Na}_{7.6} \mathrm{Al}_{6} \mathrm{Si}_{6} \mathrm{O}_{24}\left(\mathrm{CO}_{3}\right)_{1.6} \bullet 2.1 \mathrm{H}_{2} \mathrm{O}\right)\right.$ formation have been observed in the Bayer aluminum process.

The sequential transformations of $\mathrm{NAS}_{\text {gel }} \rightarrow$ Zeolite-A (cubic) $\rightarrow$ sodalite(cubic) $\rightarrow$ cancrinite (hexagonal) are densification (aging) transformations that require the saturation of the evaporator and/or tank solutions with respect to the parent NAS gel $_{\text {pel }}$ phase. Modeling the potential to form the $\mathrm{NAS}_{\text {gel }}$ phase in the feed or drop tanks, and/or in the evaporator, has been chosen because this phase is the primary phase from which all the others are derived and it is kinetically most rapid step in the formation sequence [aluminosilicate species in solution $] \rightarrow \mathrm{NAS}_{\text {gel }} \rightarrow$ Zeolite-A $\rightarrow$ sodalite $\rightarrow$ cancrinite. Indeed, experimentation at SRTC demonstrated that the nitrated-cancrinite/sodalite forming in the SRS $2 \mathrm{H}$ Evaporator forms from a Zeolite-A precursor. Modeling the denser phases, which are less soluble than the $\mathrm{NAS}_{\text {gel }}$, would unnecessarily constrict the solution chemistry range of the SRS evaporators.

Modeling of the SRS 2H- and 2F-Evaporator feed and drop tank chemistries was performed using a commercially available software package, Geochemist's Workbench (GWB). The GWB thermodynamic database is maintained by Lawrence Livermore National Laboratory (LLNL). The database contains many radioactive and some metastable phases such as hydrogels, e.g. precipitated $\mathrm{Fe}(\mathrm{OH})_{3}$, which are pertinent to the relatively short kinetic regimes during which the evaporator deposits form. The database was augmented with solubility data for $\mathrm{NaAlO}_{4}, \mathrm{Al}(\mathrm{OH})_{3}, \mathrm{AlOOH}$ developed at Hanford; 
Zeolite-A and a sodium aluminosilicate gel $\left(\mathrm{NAS}_{\mathrm{gel}}\right)$ known to form in evaporators used for processing aluminum ore via the Bayer aluminum refining process; "mixed zeolite" (a partially crystallized mixture of $\mathrm{NAS}_{\text {gel }}+$ Zeolite-A + cancrinite formed in evaporators used to process pulp and paper via the Kraft process; hydroxysodalite data generated in support of the Kraft pulp and paper process); and $\mathrm{NaNO}_{3}$. The solubility of these phases as a funciton of temperature was entered into the database at a reference 8.5 molal $\mathrm{Na}$ concentration pertinent to the evaporator solutions.

The solutions from the SRS 2H- and 2F-Evaporator systems are modeled in this study and the SRS 3H-Evaporator system is modeled in Part II of this study. Feed and drop tank data for all evaporators measured at $25^{\circ} \mathrm{C}$ were modeled at the elevated evaporator operating temperatures of $120^{\circ} \mathrm{C}$ for the SRS $2 \mathrm{H}$ - and $2 \mathrm{~F}$-Evaporators and at $140^{\circ} \mathrm{C}$ for the SRS $3 \mathrm{H}$-Evaporator. A simulated $40 \%$ evaporation was performed by basing the calculations on 600 grams of water instead of the default of 1 kilogram of water. The GWB code was validated in this complex Na-N-Si-Al-U- $\mathrm{H}_{2} \mathrm{O}$ system by also modeling data from SRS M-Area waste tanks and from experiments performed in uranyl nitrate solutions titrated with strong caustic $(\mathrm{NaOH})$. The results of the modeling validation correctly predicted the phases that had been observed to precipitate in the M-Area waste tanks and in the uranyl nitrate solutions that were near neutral when precipitation was observed.

The Variable Depth Sample (VDS) analyses discussed in this report and in Part II have shown that the feed tanks for the SRS $2 \mathrm{H}$ and $3 \mathrm{H}$-Evaporators are stratified. A colloidal layer enriched in $\mathrm{Si}, \mathrm{Fe}$, and $\mathrm{U}$ exists above the sludge that is dense and turbid. This layer is defined in this study as the "Zone of Turbidity." The ZOT does not settle well. VDS samples indicated that the ZOT had not settled in the SRS 2H-Evaporator feed tank after six weeks nor after several months of inactivity. The ZOT is likely enriched in silica colloids, which are negatively charged and repel each other (hydrophobic), prohibiting the material from settling. The VDS sample data generated by SRTC for the $2 \mathrm{H}$ and $3 \mathrm{H}$ feed tanks indicates that the ZOT is 20-24" thick. The depth of the ZOT was confirmed to be $\sim 22$ " by turbidity measurements taken in the $2 \mathrm{H}$ feed tank in March 2001.

In January 1996 the SRS 2H-Evaporator pot began operation with a new pot. The SRS $2 \mathrm{H}$ operational history can be explained in terms of the feed chemistries which varied over four different time populations. The feed chemistry time populations were based on operational records of the amount of $\mathrm{Si}(\mathrm{kgs}$.) and $\mathrm{Al}(\mathrm{kgs}$.) sent to Tank $43 \mathrm{H}$ from the Defense Waste Processing Facility (DWPF) and H-Canyon, respectively.

- High Si, low Al processing

- Moderate Si, low Al processing

- Moderate Si, moderate Al processing

- Moderate $\mathrm{Si}$, high $\mathrm{Al}$ processing

The initial fouling of the SRS 2H-Evaporator with aluminosilicates was observed during the High Si, low Al processing time regime. Initial scaling was observed in April 1997 and the Gravity Drain Line (GDL) plugged in August 1997. During this time the feed pump was in close proximity to the silica enriched ZOT until June 1997 and the DWPF recycle stream was overly enriched in silica due to uncontrolled SME carryovers which 


\section{WSRC-TR-2000-00293, Rev. 1}

contained $>50 \mathrm{wt} \%$ silica in the form of glass forming frit. The activity diagram modeling shows that the evaporator feeds were saturated with respect to the NAS gel phase and $\mathrm{Na}_{2} \mathrm{U}_{2} \mathrm{O}_{7}$. In addition, zeolite seed material was fed to the evaporator prior to the SME carryovers in the form of silica rich residues from a large scale HEME/HEPA filter dissolution demonstration performed at DWPF. Therefore, the SRS 2H-Evaporator was being fed high Si containing solutions that had seed crystals of zeolite present to initiate fouling.

Acceptable operation of the SRS 2H-Evaporator occurred during the moderate $\mathrm{Si}$, low $\mathrm{Al}$ time regime. A new feed pump had been installed at 100", well above the silica enriched ZOT. The DWPF recycle stream contained only a few SME carryovers and several of them did not contain glass forming frit. The activity diagram modeling shows that the evaporator feeds were not saturated with respect to the $\mathrm{NAS}_{\mathrm{gel}}$ phase but were saturated with respect to $\mathrm{Na}_{2} \mathrm{U}_{2} \mathrm{O}_{7}$.

The second period of fouling of the SRS 2H-Evaporator was initiated during the moderate $\mathrm{Si}$, moderate $\mathrm{Al}$ time regime. The GDL plugged for the second time and deposits were noted on the coils and walls only 2 months after this time regime began. The feed pump remained at 100", well above the silica enriched ZOT. The DWPF recycle stream contained no SME carryovers but H-Canyon started to send wastes moderately high in Al. The activity diagram modeling shows that the evaporator feeds were initially unsaturated with respect to the $\mathrm{NAS}_{\text {gel }}$ phase but became saturated with respect to this phase as the $\mathrm{Al}$ concentration in the feed increased. The evaporator solutions were saturated with respect to $\mathrm{Na}_{2} \mathrm{U}_{2} \mathrm{O}_{7}$ during the moderate $\mathrm{Al}$ time regime.

The second period of fouling of the SRS 2H-Evaporator progressively worsened during the moderate Si, high Al time regime. Significant deposits were observed on all internal surfaces of the evaporator during this time regime. The feed pump remained at 100", well above the silica enriched ZOT. The DWPF recycle stream contained no SME carryovers but $\mathrm{H}$-Canyon started to send wastes extremely high in $\mathrm{Al}$ at a very frequent rate. The activity diagram modeling shows that the evaporator feeds were saturated with respect to both the $\mathrm{NAS}_{\text {gel }}$ phase and $\mathrm{Na}_{2} \mathrm{U}_{2} \mathrm{O}_{7}$.

Activity diagram modeling of the SRS 2F-Evaporator indicates this system is not saturated with respect to aluminosilicate formation. Comparison of historic chemical data from the SRS 3H Evaporator feed tanks from 1992 to recent (post 1997) indicates that more Si-rich feeds may be fed to these systems now; this is not supported by the data for the other evaporator systems. Potential causes for these trends may include the following: (1) bad analytic data for Si (only one sample exists) in 1992 for the SRS 3Hand 2F-Evaporator feed tanks; (2) waste is no longer stored for a year before being processed so less settling occurs; (3) the practice of using alternating drop tanks, one active and one passive, is no longer viable which prevents settling from occurring; and/or (4) more frequent inter-area transfers and co-mingling of wastes.

Thermodynamic modeling using GWB included the determination of a supersaturation index, $\log \mathrm{Q} / \mathrm{K}$, for the SRS evaporator systems. A mechanistic process control algorithm was developed based on the $\log \mathrm{Q} / \mathrm{K}$ calculations to use as a tool to "qualify" feeds for the SRS evaporators and prevent aluminosilicate deposition. The saturation 


\section{WSRC-TR-2000-00293, Rev. 1}

index at the elevated evaporator temperature with a simulated $40 \%$ evaporation was regressed versus measured tank chemistries measured at $25^{\circ} \mathrm{C}$ such as $\log [\mathrm{Si}(\mathrm{M})]$, $\log [\mathrm{Al}(\mathrm{M})], \log [\mathrm{OH}(\mathrm{M})], \log [\mathrm{Na}(\mathrm{M})]$. The mechanism modeled is the equilibrium equation for the boundary on the activity diagrams that separates the tank solutions that can precipitate aluminosilicates from those that do not, e.g. the boundary between diaspore $(\mathrm{AlOOH})$ and $\mathrm{NAS}_{\mathrm{gel}}$. Since $\mathrm{Na}$ is not routinely measured in the tank farm, a simplified mechanistic model with an $\mathrm{R}^{2}$ of 0.90 was developed. Use of the simplified mechanistic model has already shown that the solubility product criteria, $[\mathrm{Al}] *[\mathrm{Si}]$ in $\mathrm{M}^{2}$ recently used to qualify feeds for the SRS 3H-Evaporator is overly conservative based on operational history of the SRS 2F-Evaporator feeds.

The following recommendations from this study should be evaluated as soon as feasible:

- Feed pumps for the SRS evaporators should be maintained at $>20$ " above the "Zone of Turbidity" which is $\sim 40 "$ above the sludge layer (distances based on depths of variable samples taken and March 2001 turbidity measurements.

- Drop tank transfer jets should be maintained at positions higher than the salt layer to avoid recycling any precipitated $\mathrm{Fe}(\mathrm{OH})_{3}$, saturated silica solutions, and/or entrained sludge solids back to the feed tank. Since silica rich feeds can supersaturate $>200 \%$, this will allow any supersaturation in the evaporator to precipitate in the cooler temperature environment of the drop tank.

- A longer term strategy for the SRS 2H-Evaporator system would be to eliminate recycle directly from the drop tank to the feed tank, e.g. recycle to a pre-feed tank, and to bring in fresh feed from a pre-feed tank that would allow any silica-rich phases added time to settle out.

- Routine analytic samples, if used for modeling, should be taken at the height of the feed pump.

- Analytic samples should not be taken within 5-6 hours of tank transfers and/or recent tank recycles.

- A more accurate Si analysis method must be implemented in the F-Area laboratory immediately.

- A minimum of three wet chemical analyses need to be made on any sample pulled from the evaporator feed tanks in order to achieve better statistical confidence.

- The process model developed in this study must be validated by SRTC using laboratory data being developed at the Pacific Northwest National Laboratory (PNNL).

- Implementation of the process model for operation of the SRS 2H-Evaporator must include a sensitivity analysis (range of applicability) in order to assure 


\section{WSRC-TR-2000-00293, Rev. 1}

that the evaporator will not process any feeds that are outside the range for which the model was developed.

- Implementation of the process model for operation of the SRS 2H-Evaporator must include incorporation of the various sources of error (model error, analytic error, concentration error, tank transfer errors, etc.) so that the level of confidence desired can be guaranteed by the final operating envelope.

- The desired confidence level for the prevention of aluminosilicate deposition must be specified by the tank farm, e.g. $>95 \%, 95 \%, 90 \%$, in order to implement the process model. 


\section{TABLE OF CONTENTS}

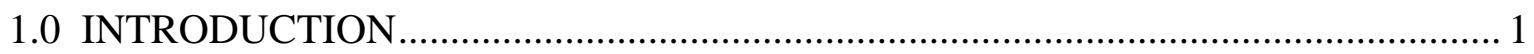

2.0 BACKGROUND....................................................................................... 2

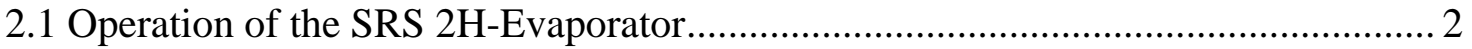

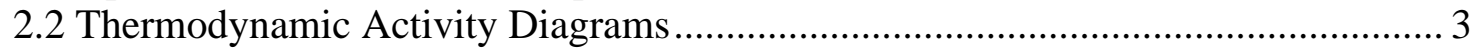

2.3 Zeolite, Sodalite, and Cancrinite Nomenclature and Paragenesis ........................... 7

2.4 Uranium Phase Paragenesis ............................................................................ 12

2.5 Amorphous Aluminate Phase Paragenesis ..................................................... 13

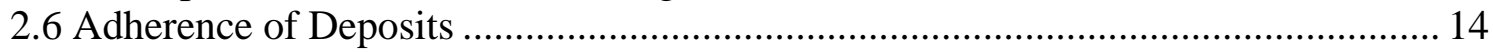

3.0 ACTIVITY DIAGRAM CALCULATIONAL APPROACH.................................. 17

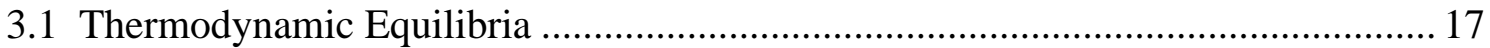

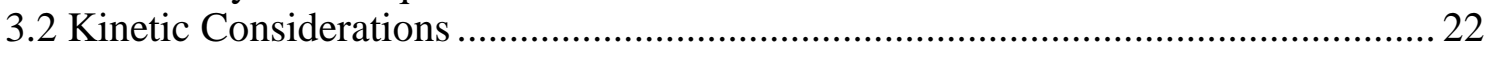

4.0 OPERATIONAL HISTORY OF THE SRS 2H-Evaporator..................................... 23

5.0 ANALYTIC DATA AVAILABLE FOR SRS 2H-Evaporator MODELING ............... 27

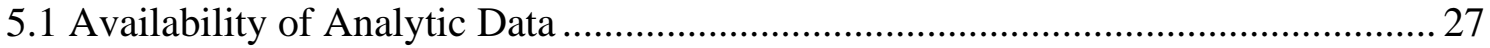

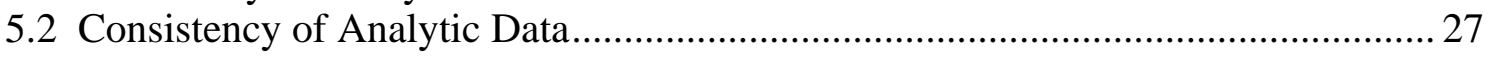

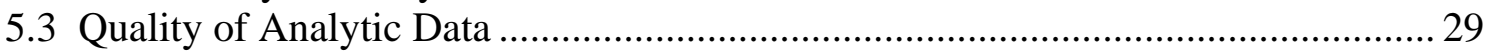

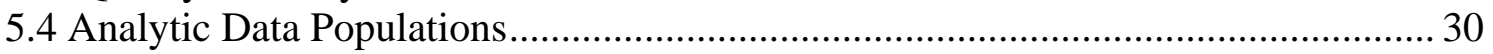

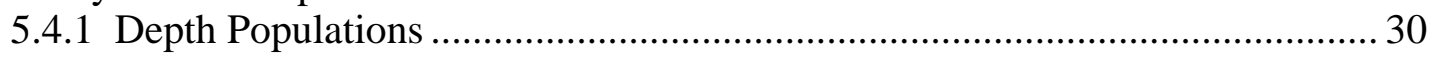

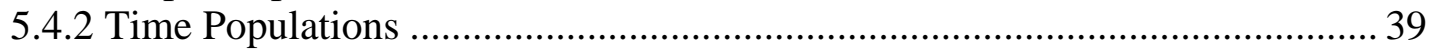

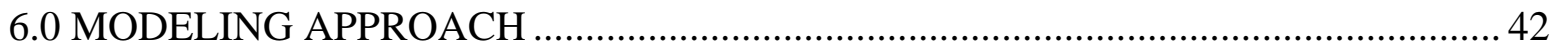

7.0 ACTIVITY DIAGRAMS FOR THE SRS 2H-Evaporator ...................................... 46

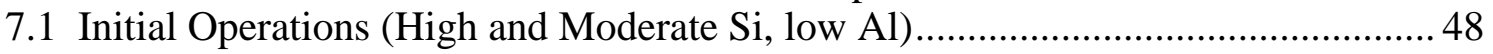

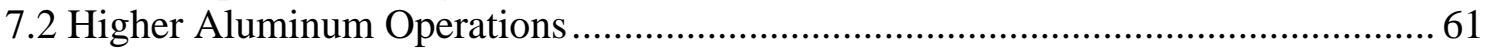

8.0 ACTIVITY DIAGRAM MODELING FOR THE SRS 2F-Evaporator....................... 72

8.1 Operation Comparison Between the SRS 2F and 2H-Evaporators ....................... 72

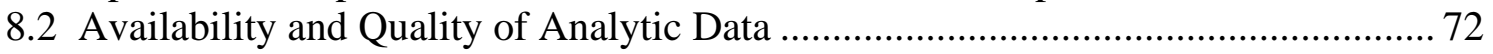

8.3 Aluminosilicate Activity Diagrams............................................................ 73

9.0 CURRENT VS. HISTORIC OPERATION OF ALL SRS EVAPORATORS ............. 82

10.0 SUPERSATURATION OF THE SRS 2H-Evaporator SYSTEM COMPARED

TO THE 3H AND 2F-Evaporator SYSTEMS ........................................................ 82

11.0 A PROCESS MODEL FOR OPERATION OF SRS EVAPORATORS....................90

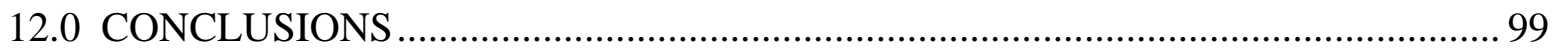

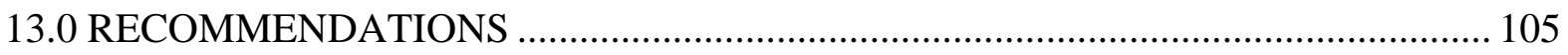


WSRC-TR-2000-00293, Rev. 1

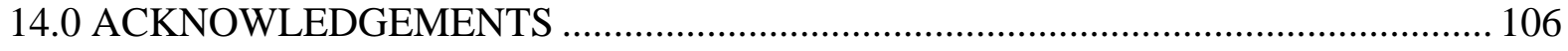

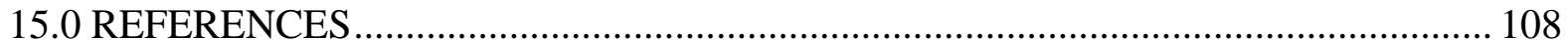

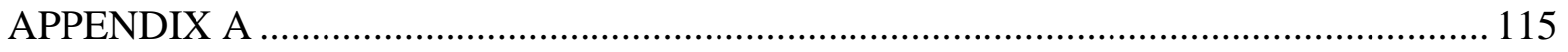

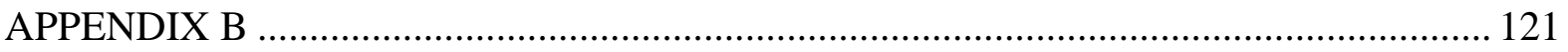

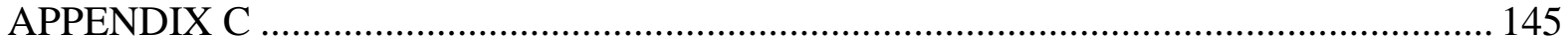

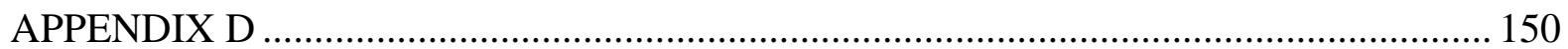




\section{WSRC-TR-2000-00293, Rev. 1}

\section{LIST OF FIGURES}

Figure 1. Part of the aluminosilicate framework in the structure of sodalite

Figure 2. Typical aging (densification) sequence of $\mathrm{NAS}_{\text {gel }} \rightarrow$ Zeolite-A $\rightarrow$ sodalite $\rightarrow$ cancrinite phases depending on the relative concentration of $\mathrm{OH}^{-}, \mathrm{Cl}^{-}$, $\mathrm{NO}_{3}$, and/or $\mathrm{CO}_{3}{ }^{=}$in the solution in contact with the $\mathrm{NAS}_{\mathrm{gel}}$ 11

Figure 3. Stepwise generation of an activity diagram for the Na-Al-Si-O-H system ......... 20

Figure 4. Time line of Si transfers in $\mathrm{kgs}$ from DWPF and Al transfers in kgs from $\mathrm{H}$-Canyon for the SRS 2H-Evaporator. 25

Figure 5. Schematic of the SRS 2H-Evaporator 32

Figure 6. Depth populations delineated in the SRS 2H-Evaporator Feed Tank (Tank 43H)

Figure 7. Pictorial diagram showing the differences between a sol, gel, and precipitate

Figure 8. Cumulative sum chart of the $\mathrm{Si}(\mathrm{kgs})$ and $\mathrm{Al}(\mathrm{kgs})$ received by the SRS 2H-Evaporator feed tank (Tank 43H)

Figure 9. Overlay of $\mathrm{Si}(\mathrm{M}) * 10000$ for the SRS $2 \mathrm{H}$-Evaporator Feed amd Drop Tanks overlain on the $\mathrm{Si}(\mathrm{kgs})$ known to be sent from DWPF to the evaporator

Figure 10. Activity diagram showing how the stability boundaries for gibbsite and diaspore change when the solubility data of Russell is substituted for the $\mathrm{Al}(\mathrm{OH})_{3}$ and $\mathrm{AlOOH}$ data in GWB

Figure 11. Relative Stability Boundaries of NAS ${ }_{\text {gel }}$ " "mixed zeolite," Zeolite-A and hydroxysodalite. 46

Figure 12. Aluminosilicate (NAS) activity diagram at $25^{\circ} \mathrm{C}$ for Tank $43 \mathrm{H}$ (feed tank) ...... 54

Figure 13. Aluminosilicate (NAS) activity diagram at $25^{\circ} \mathrm{C}$ for Tank $38 \mathrm{H}$ (drop tank) ...... 54

Figure 14. Aluminosilicate (NAS) activity diagram at $40^{\circ} \mathrm{C}$ for Tank $43 \mathrm{H}$ (feed tank) ......55

Figure 15. Aluminosilicate (NAS) activity diagram at $40^{\circ} \mathrm{C}$ for Tank $38 \mathrm{H}$ (drop tank) ...... 55

Figure 16. Aluminosilicate (NAS) activity diagram at $120^{\circ} \mathrm{C}$ for Tank $43 \mathrm{H}$ (feed tank) 
Figure 17. Aluminosilicate (NAS) activity diagram at $120^{\circ} \mathrm{C}$ for Tank $38 \mathrm{H}$ (drop tank)

Figure 18. Aluminosilicate (Mixed Zeolite) activity diagram at $120^{\circ} \mathrm{C}$ for Tank $43 \mathrm{H}$ (feed tank)

Figure 19. Aluminosilicate (Mixed Zeolite) activity diagram at $120^{\circ} \mathrm{C}$ for Tank $38 \mathrm{H}$ (drop tank)

Figure 20. Diuranate activity diagram for Tank $43 \mathrm{H}$ at $25^{\circ} \mathrm{C}$ during the low alumina (high and moderate $\mathrm{Si}$ ) time populations 58

Figure 21. Diuranate activity diagram for Tank $38 \mathrm{H}$ at $25^{\circ} \mathrm{C}$ during the low alumina (high and moderate $\mathrm{Si}$ ) time populations

Figure 22. Diuranate activity diagram for Tank $43 \mathrm{H}$ at $40^{\circ} \mathrm{C}$ during the low alumina (high and moderate $\mathrm{Si}$ ) time populations

Figure 23. Diuranate activity diagram for Tank $38 \mathrm{H}$ at $40^{\circ} \mathrm{C}$ during the low alumina (high and moderate $\mathrm{Si}$ ) time populations

Figure 24. Diuranate activity diagram for Tank $43 \mathrm{H}$ at $120^{\circ} \mathrm{C}$ during the low alumina (high and moderate $\mathrm{Si}$ ) time populations

Figure 25. Diuranate activity diagram for Tank $38 \mathrm{H}$ at $120^{\circ} \mathrm{C}$ during the low alumina (high and moderate $\mathrm{Si}$ ) time populations

Figure 26. Aluminosilicate (NAS) activity diagram at $25^{\circ} \mathrm{C}$ for Tank $43 \mathrm{H}$ during the moderate alumina and high alumina time populations.

Figure 27. Aluminosilicate (NAS) activity diagram at $25^{\circ} \mathrm{C}$ for Tank $38 \mathrm{H}$ during moderate alumina and high alumina time populations.

Figure 28. Aluminosilicate (NAS) activity diagram at $40^{\circ} \mathrm{C}$ for Tank $43 \mathrm{H}$ during the moderate alumina and high alumina time populations.

Figure 29. Aluminosilicate (NAS) activity diagram at $40^{\circ} \mathrm{C}$ for Tank $38 \mathrm{H}$ during moderate alumina and high alumina time populations.

Figure 30. Aluminosilicate (NAS) activity diagram at $120^{\circ} \mathrm{C}$ for Tank $43 \mathrm{H}$ during the moderate alumina and high alumina time populations.

Figure 31. Aluminosilicate (NAS) activity diagram at $120^{\circ} \mathrm{C}$ for Tank $38 \mathrm{H}$ during moderate alumina and high alumina time populations. 66

Figure 32. Aluminosilicate (Mixed Zeolite) activity diagram at $120^{\circ} \mathrm{C}$ for Tank $43 \mathrm{H}$ during the moderate alumina and high alumina time populations 


\section{WSRC-TR-2000-00293, Rev. 1}

Figure 33. Aluminosilicate (Mixed Zeolite) activity diagram at $120^{\circ} \mathrm{C}$ for Tank $38 \mathrm{H}$ during moderate alumina and high alumina time populations

Figure 34 . Diuranate activity diagram at $25^{\circ} \mathrm{C}$ for Tank $43 \mathrm{H}$ during the moderate alumina and high alumina time populations

Figure 35 . Diuranate activity diagram at $25^{\circ} \mathrm{C}$ for Tank $38 \mathrm{H}$ during moderate alumina and high alumina time populations

Figure 36. Diuranate activity diagram at $40^{\circ} \mathrm{C}$ for Tank $43 \mathrm{H}$ during the moderate alumina and high alumina time populations

Figure 37 . Diuranate activity diagram at $40^{\circ} \mathrm{C}$ for Tank $38 \mathrm{H}$ during moderate alumina and high alumina time populations

Figure 38. Diuranate activity diagram at $120^{\circ} \mathrm{C}$ for Tank $43 \mathrm{H}$ during the moderate alumina and high alumina time populations

Figure 39. Diuranate activity diagram at $120^{\circ} \mathrm{C}$ for Tank $38 \mathrm{H}$ during moderate alumina and high alumina time populations

Figure 40. Aluminosilicate (NAS) activity diagram at $25^{\circ} \mathrm{C}$ for the $2 \mathrm{~F}$-Evaporator feed tank (Tank 26F)

Figure 41. Aluminosilicate (NAS) activity diagram at $25^{\circ} \mathrm{C}$ for the $2 \mathrm{~F}$-Evaporator drop tank (Tank 46F.

Figure 42. Aluminosilicate (NAS) activity diagram at $40^{\circ} \mathrm{C}$ for the $2 \mathrm{~F}$-Evaporator feed tank (Tank 26F

Figure 43. Aluminosilicate (NAS) activity diagram at $40^{\circ} \mathrm{C}$ for the $2 \mathrm{~F}$-Evaporator drop tank (Tank 46F)

Figure 44. Aluminosilicate (NAS) activity diagram at $120^{\circ} \mathrm{C}$ for the $2 \mathrm{~F}$-Evaporator feed tank (Tank 26F)

Figure 45. Aluminosilicate (NAS) activity diagram at $120^{\circ} \mathrm{C}$ for the $2 \mathrm{~F}$-Evaporator drop tank (Tank 46F

Figure 46. Aluminosilicate (Mixed Zeolite) activity diagram at $120^{\circ} \mathrm{C}$ for the $2 \mathrm{~F}$ Evaporator feed tank (Tank 26F

Figure 47. Aluminosilicate (Mixed Zeolite) activity diagram at $120^{\circ} \mathrm{C}$ for the $2 \mathrm{~F}$ Evaporator drop tank (Tank 46F).

Figure 48. Comparison of 1992 historic data to current operational data for the SRS $3 \mathrm{H}, 2 \mathrm{H}$ and $2 \mathrm{~F}$-Evaporators at the tank temperature of $40^{\circ} \mathrm{C}$. 85 


\section{WSRC-TR-2000-00293, Rev. 1}

Figure 49. Potential process control model for the SRS evaporators 94

Figure 50. Simplified process control model for the SRS evaporators 95

Figure A1. Comparison of the ion activity coefficient of $\mathrm{Ca}^{2+}$.....

Figure B1. Comparison of Iler et al. Silica Solubilities with THERMO Predictions

Figure B2. Reynolds and Herting Sodium Aluminate Solubilities as a Function of Temperature and $[\mathrm{NaOH}]$.

Figure B3. Variation of the log Formation Constant for Gibbsite with $[\mathrm{Na}]$ at $70^{\circ} \mathrm{C}$

Figure B4. Variation of the log Formation Constant for Diaspore with $[\mathrm{Na}]$ at $130^{\circ} \mathrm{C}$.

Figure B5. Correlation of $\log \left(\mathrm{K}_{\mathrm{f}}\right)$ for Gibbsite as a Function of Temperature

Figure B6. Correlation of $\log \left(\mathrm{K}_{\mathrm{f}}\right)$ for Diaspore as a Function of Temperature.

Figure B7. Comparison of the Default THERMO and Russell et. al Solubility Constants for Gibbsite.

Figure B8. Comparison of the Default THERMO and Russell et. al Solubility Constants for Diaspore.

Figure B9. Ejaz and Jones Silicate Solubilities as a Function of Temperature and $[\mathrm{NaOH}]$

Figure B10.Ejaz and Jones Aluminate Solubilities as a Function of Temperature and $[\mathrm{NaOH}]$.

Figure B11.Variation of $\mathrm{NAS}_{\mathrm{gel}}$ Solubility Product with Sodium Concentration 136

Figure B12.Variation of Zeolite-A Solubility Product with Sodium Concentration 136

Figure B13.Variation of $\mathrm{NAS}_{\text {gel }}$ Solubility Product with Temperature when $[\mathrm{Na}+]=$ 8.5 molal.

Figure B14.Variation of Zeolite-A Solubility Product with Temperature when [Na+] $=8.5$ molal

Figure B15.Park and Englezos Solubility Measurements for 1.0 Molal Carbonate Solutions.

Figure B16.Park and Englezos Solubility Measurements for 0.3 Molal Carbonate Solutions. 


\section{WSRC-TR-2000-00293, Rev. 1}

Figure $\mathrm{C} 1$. Activity diagram for M-Area Tank 6 showing that the supernate was in the stability field of gibbsite when the tanks were well mixed/agitated

Figure C2. Activity diagram for M-Area Tank 8 showing that the supernate was in the stability field of gibbsite when the tanks were well mixed/agitated.

Figure C3. Activity diagram for M-Area Tank 6 showing that the sludge was in the stability field of Zeolite-A after agitation was stopped and the solids were allowed to settle.

Figure C4. Activity diagram for M-Area Tank 6 showing that the sludge was in the stability field of Zeolite-A after agitation was stopped and the solids were allowed to settle.

Figure C5. Activity diagram for M-Area Tank 6 showing that the supernates were in equilibrium with respect to $\mathrm{Na}_{2} \mathrm{U}_{2} \mathrm{O}_{7}$ when they were well mixed/agitated. This is the phase that precipitated in the sludge when the supernates were no longer agitated.

Figure C6. Activity diagram for M-Area Tank 6 showing that the supernates were in equilibrium with respect to $\mathrm{Na}_{2} \mathrm{U}_{2} \mathrm{O}_{7}$ when they were well mixed/agitated. This is the phase that precipitated in the sludge when the supernates were no longer agitated

Figure C7. X-ray diffraction pattern of precipitate from Pierce's neutralization experiment showing the identification of becquelerite/schoepite

Figure C8. Activity diagram for Pierce neutralization experiment at $25^{\circ} \mathrm{C}$ demonstrating that the solutions were in the stability field of schoepite

Figure C9. Activity diagram for Pierce neutralization experiment at $70^{\circ} \mathrm{C}$ demonstrating that the solutions were in the stability field of schoepite. 


\section{LIST OF TABLES}

Table I. Structurally Related Zeolite-A, Sodalite, and Cancrinite Group Phases............... 8

Table II. Mass Balance of Evaporator Wall and Pot Deposits.......................................... 14

Table III. Significant Events During the SRS 2H-Evaporator Operation ............................ 26

Table IV. Available Tank 43 Analytic Data Including Si for SRS 2H-Evaporator

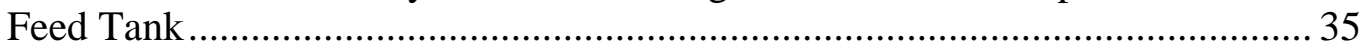

Table V. Available Tank 38 Analytic Data Including Si for SRS 2H-Evaporator

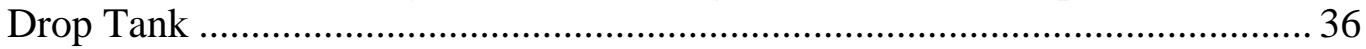

Table VI. Tank 43 Modeling Data for SRS 2H-Evaporator Feed Tank .............................. 37

Table VII. Tank 38 Modeling Data for SRS 2H-Evaporator Drop Tank ............................. 38

Table VIII.Chemically Distinct Time Populations Experienced in the SRS 2HEvaporator

Table IX. Available Tank 26F Analytic Data Including Si for SRS 2F-Evaporator

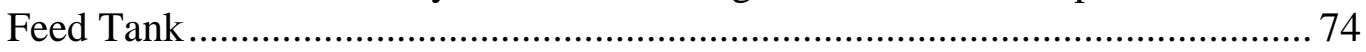

Table X. Available Tank 46F Analytic Data Including Si for SRS 2F-Evaporator Drop Tank .75

Table XI. Tank 26F Modeling Data for SRS 2F-Evaporator Feed Tank ............................ 76

Table XII. Tank 46F Modeling Data for SRS 2F-Evaporator Drop Tank ............................. 77

Table XIII.Supersaturation of 2H-Evaporator Feed Tank (Tank 43H) Solutions with Respect to Aluminosilicate Formation.

Table XIV.Supersaturation of 2H-Evaporator Drop Tank (Tank 38H) Solutions with Respect to Aluminosilicate Formation.

Table XV. Supersaturation of 2F-Evaporator Feed Tank (Tank 26F) Solutions with Respect to Aluminosilicate Formation. 88

Table XVI.Supersaturation of 2F-Evaporator Drop Tank (Tank 46F) Solutions with Respect to Aluminosilicate Formation.

Table A1. Effects Modeled in the Various Approaches to Activity Coefficient Estimation in High Ionic Strength Solutions

Table B1. Measured Silicon Solubilities and Calculated Silicon Activities at $25^{\circ} \mathrm{C}$ 123 


\section{WSRC-TR-2000-00293, Rev. 1}

Table B2. Summary of Formation Constant Calculations for the Solubility of Sodium Aluminate

Table B3. Results of Geochemist's Workbench Calculations of $\mathrm{K}_{\mathrm{f}}$ for Gibbsite ..... 128

Table B4. Results of Geochemist's Workbench Calculations of $\mathrm{K}_{\mathrm{f}}$ for Diaspore

Table B5. Comparison of Gibbsite Formation Constants Calculated in This Work with Those fromthe THERMO Database.

Table B6. Comparison of Diaspore Formation Constants Calculated in This Work with Those from the THERMO Database.

Table B7. Ejaz et al. NAS ${ }_{\text {gel }}$ Solubility Measurements

Table B8. Ejaz et al. Zeolite-A Solubility Measurements

Table B9. Extrapolated Solubilities and Formation Constants for NAS at $\left[\mathrm{Na}^{+}\right]=8.5$ molal.

Table B10.Extrapolated Solubilities and Formation Constants for Zeolite A at $\left[\mathrm{Na}^{+}\right]=$ 8.5 molal.

Table B11.Experiment Numbers and X-Ray Diffraction Identifications for Gasteiger and Frederick Solubility Data

Table B12.Gasteiger and Frederick Solubility Data

Table B13.Evaluation of Arrhenius Factor for Temperature Depedence of Mixed Zeolite Solubility.....

Table B14.Extrapolated Solubilities and Formation Constants for Mixed Zeolite at $\left[\mathrm{Na}^{+}\right]=8.5$ molal

Table B15.Park and Engelos Solubility Data.

Table B16.Extrapolated Solubilities and Formation Constants for Hydroxysodalite at $\left[\mathrm{Na}^{+}\right]=8.5$ molal

Table C1. Analytic Molar Concentrations for M-Area Tanks and Pierce Neutralization Experiment

Table C2. Molal Concentrations for M-Area Tanks and Pierce Neutralization Experiment 


\section{LIST OF ACRONYMS}

ACT-2: $\quad$ ACTivity Diagram Subroutine in GWB

ANL-W: $\quad$ Argonne National Laboratory-West

BDL: $\quad$ Below Detection Limit

DOE: $\quad$ United States Department of Energy

DWPF: $\quad$ Defense Waste Processing Facility

ESP: $\quad$ Extended Sludge Processing

GDL: Gravity Drain Line

GWB: Geochemist's Workbench Software

HAW: High Activity Waste

HEME: $\quad$ High Efficiency Mist Eliminator

HEPA: High Efficiency Particulate Air

HMW: $\quad$ Harvie-Møller-Weare Activity Coefficient Model

LLNL: $\quad$ Lawrence Livermore National Laboratory

NAS $_{\text {gel }}$ : $\quad$ Sodium Alumino-Silicate gel

PC: $\quad$ Personal Computer

PNNL: $\quad$ Pacific Northwest National Laboratory

REACT: $\quad$ Reaction Path Subroutine in GWB

RHS: $\quad$ Right Hand Side

RW-0333P: DOE Level of Quality Assurance

SME: $\quad$ Slurry Mix Evaporator

SRS: $\quad$ Savannah River Site

SRTC: $\quad$ Savannah River Technology Center

VDS: $\quad$ Variable Depth Samples

WSRC: Westinghouse Savannah River Company

XRD: $\quad$ X-Ray Diffraction

ZOT: $\quad$ Zone of Turbidity 
WSRC-TR-2000-00293, Rev. 1

This page intentionally left blank. 


\title{
THERMODYNAMIC MODELING OF THE SRS EVAPORATORS: PART I. THE 2H AND 2F SYSTEMS (U)
}

\author{
C. M. Jantzen, J. E. Laurinat, and K.G. Brown \\ Savannah River Technology Center \\ Westinghouse Savannah River Company \\ Aiken, South Carolina 29808
}

\subsection{INTRODUCTION}

Accumulations of two solid phases (a nitrated aluminosilicate that is a mixture of nitrated cancrinite, $\mathrm{Na}_{8} \mathrm{Al}_{6} \mathrm{Si}_{6} \mathrm{O}_{24}\left(\mathrm{NO}_{3}\right)_{2} \bullet 4 \mathrm{H}_{2} \mathrm{O}$, and nitrated sodalite, $\mathrm{Na}_{8} \mathrm{Al}_{6} \mathrm{Si}_{6} \mathrm{O}_{24}\left(\mathrm{NO}_{3}\right)_{2}$, precipitated with sodium diuranate, $\mathrm{Na}_{2} \mathrm{U}_{2} \mathrm{O}_{7}$ ) occurred in the Savannah River Site (SRS) 2H-Evaporator system since late 1996. ${ }^{1,2}$ The aluminosilicate scale deposits caused the evaporator to become inoperable in October 1999. Accumulations of the diuranate phase have caused criticality concerns in the SRS $2 \mathrm{H}$-Evaporator.

In this study, thermodynamically derived activity diagrams, also known as stability diagrams, are developed from historic analytic data from the SRS 2H-Evaporator system feed tank (Tank 43H) and drop tank (Tank 38H) in order to understand the tank chemistry conditions that caused the scale formation in the $2 \mathrm{H}$-Evaporator. The SRS 2F-Evaporator system, which is not precipitating aluminosilicate solids, is modeled for comparison. A simple process control model is developed based on the thermodynamic modeling of the SRS $2 \mathrm{H}$ - and 2F-Evaporator systems. The process control model is validated on the thermodynamic modeling of the SRS 3H-Evaporator system, which also is not precipitating aluminosilicate solids. Modeling of the SRS $3 \mathrm{H}$-Evaporator system is discussed in Part II of this study. ${ }^{3}$

Activity diagrams are most commonly used in electrochemistry, geochemistry and agronomy to study the effects of various aqueous species on the formation and/or dissolution of solids. Activity diagram representation can, therefore, be used to calculate if an evaporator feed tank composition lies in the formation field of an undesirable solid species. Modeling the potential for deposition of solids in the SRS $2 \mathrm{H}$ and $2 \mathrm{~F}-$

Evaporators means that activity diagrams must be calculated in the complex Na-N-Si-Al$\mathrm{U}-\mathrm{H}_{2} \mathrm{O}$ system at elevated temperatures and at high ionic strengths (I 8). Modeling accuracy is impacted by the following:

- $\quad$ quality of the chemical data available from the feed and drop tanks

- $\quad$ how representative the analytic dip samples from the feed and drop tank are of the feed entering the evaporator

- $\quad$ quality of the solubility data used from the literature 
- $\quad$ quality of the approximations that must be made to determine the activity coefficients for high ionic strength solutions.

The quality of the solubility data and the quality of the approximations that are used to model high ionic strength solutions are discussed in Appendix A and B of this study. The quality of the chemical data available for the SRS 2H- and 2F-Evaporators and the quality of the sampling is discussed this study. The quality of the chemical data for the SRS $3 \mathrm{H}-$ Evaporator is discussed in Part II of this study. ${ }^{3}$

\subsection{BACKGROUND}

\subsection{Operation of the SRS 2H-Evaporator}

For $\sim 40$ years, the SRS tank farm evaporators have run with only occasional operational problems, e.g., salt $\left(\mathrm{NaNO}_{3}\right)$ buildup has caused difficulty in draining evaporators but these deposits are water soluble and easily removed by flushing with hot water. Over the last decade several important changes have been made in the handling of wastes entering the SRS evaporators.* Prior to the middle 1990's, high activity waste was stored for $>1$ year before being processed in the evaporators so that the short-lived radionuclides could decay before waste was concentrated. This also allowed any solids or colloidal species in the wastes to settle to the bottom of the tank before being processed. When the SRS reactors shut down and wastes were less radioactive, the one-year hold strategy was no longer required.

In addition, the evaporators used to discharge to alternate drop tanks. When one drop tank was filled it was left to settle and a second drop tank was used. Any recycles to the feed tank were made from the passive drop tank and not the active drop tank. This allowed any particulates or colloids in a given drop tank to settle before being recycled to the feed tank again for further concentration. The active/passive drop tank practice had to be discontinued in the early 1990's since there was no longer enough salt drop space in the concentrate receipt tanks.

In 1997, the first inter-area waste transfers were made between the SRS H-area and the SRS F-area waste tanks for the purpose of volume reducing the waste. This allowed comingling of wastes of different chemistries. More recently, a decision was made to only concentrate the wastes in the $2 \mathrm{H}$ and $2 \mathrm{~F}$-Evaporators to a specific gravity of $1.4-1.46 \mathrm{~g} / \mathrm{ml}$ while allowing the $3 \mathrm{H}$-Evaporator to concentrate to a specific gravity of $1.6 \mathrm{~g} / \mathrm{ml}$. This practice reduces, but does not eliminate salt cake formation.

A new 2H-Evaporator pot was installed and began operating in January 1996. From mid 1996 until August 1997 the SRS 2H-Evaporator became increasingly hard to control.

When the evaporator was shut down in August 1997 for cleaning, deposits of the sodium

\footnotetext{
* Synopsis by Kent Gilbreth, Mark Mahoney, and Thomas Caldwell (May 2001)

\# HLW System Plan, Rev. 11 (March 22. 2001)

2
} 
aluminosilicate and sodium uranate phases were found in the gravity drain line (GDL). ${ }^{4}$ The GDL was pressure washed in the direction of the drop tank. The line remained clean and the evaporator showed minimal deposits on the walls or in the lines from August 1997 to June 1998. In June 1998 the GDL needed to be pressure washed a second time and deposits were observed in the evaporator cone, on the vessel walls and on the warming tubes. The GDL was pressure washed in the direction of the evaporator and in the direction of the drop tank to ensure that it was clean. Operation continued, with difficulty, from June 1998 until October 1999, when the evaporator was shut down. At this time, significant accumulations of the same deposits were found on many of the exposed surfaces of the evaporator pot.

Waste from $\mathrm{H}$-Canyon separation processes is typically rich in aluminum species when received in the $2 \mathrm{H}$-Evaporator feed tank (Tank $43 \mathrm{H})$ where it undergoes concentration of $60-70 \%$ in the evaporator. However, the newly installed $2 \mathrm{H}$-Evaporator pot received little high alumina waste from High Activity Waste (HAW) processing until April 1998. In March 1996, Tank 43H received the first radioactive transfers of a silica rich stream from the Defense Waste Processing Facility (DWPF) recycle. The relatively low salt content of the DWPF recycle stream required greater concentration $(90 \%)$ than typical $\mathrm{H}$ Canyon wastes to achieve comparable concentrated solution density. Multiple transfers of supernate from the drop tank (Tank $38 \mathrm{H}$ ) were recycled back to the feed tank (Tank $43 \mathrm{H})$ for further concentration. At some time after the silica rich DWPF transfers were received from the DWPF and mixed with the aluminum rich transfers from $2 \mathrm{H}$-Canyon separation processes, the sodium aluminosilicate began to form in the $2 \mathrm{H}$-Evaporator.

\subsection{Thermodynamic Activity Diagrams}

Activity diagrams, also known as stability diagrams, have been used for about 60 years in the electrochemical sciences. Marcell Pourbaix developed this graphical representation method in 1938 for studying the corrosion of solids in aqueous solution. The Pourbaix or $\mathrm{E}^{\circ}$ - $\mathrm{pH}$ diagrams are also used to understand the corrosion of metals in concentrated or dilute aqueous solutions, at a variety of temperatures and in oxidizing or reducing atmospheres.

Garrels, a geochemist, studied under Pourbaix and applied the activity diagram calculation approach to complex interactions between minerals and solutions of geological interest. Geochemical applications included examples whereby minerals precipitated from solution as well as examples of how minerals dissolved in various solutions. ${ }^{5,6}$ Activity diagrams are capable of predicting solubilities of solid mineral species in aqueous solutions, equilibria among different solid minerals, and equilibria among different aqueous species. The geologic systems most commonly studied are: (1) the formation or dissolution of minerals in ground water or in sea water at ambient temperatures (for this application they are often called Eh-pH diagrams), ${ }^{7}$ (2) weathering of mineral phases at ambient temperature, ${ }_{7}^{7}(3)$ formation of kaolinite and bauxite deposits from weathering of other mineral species, ${ }^{7}$ and (4) formation of ores from hydrothermal mineralizing solutions at temperatures $\leq 300^{\circ} \mathrm{C}$ and pressures deep within the earth. ${ }^{6}$ 
Activity diagrams are also used in agronomy to study aerobic and anaerobic soil chemistry: for soil applications they are commonly known as pe-pH diagrams.

Activity diagrams have been used to model the dissolution reactions of zeolites at ambient temperatures: the predicted stability of the zeolite phases has been well correlated with experimental data. ${ }^{8}$ The dissolution of zeolites in the rock at the proposed high level waste (HLW) repository in Yucca Mountain, Nevada has also been modeled and studied in terms of activity diagrams. ${ }^{9}$ It is, therefore, appropriate to use activity diagram representation to model the nitrated cancrinite/sodalite found to deposit in the SRS 2H-Evaporator, since the cancrinite/sodalite forms from a precursor zeolite phase which in turn forms from a sodium aluminosilicate (NAS) gel (see Section 2.3).

Activity diagrams can be used to thermodynamically predict both mineral phase formation and dissolution on geologic time scales. However, the formation of the $\mathrm{NAS}_{\mathrm{gel}}$ precursor to nitrated cancrinite/sodalite and sodium diuranate is kinetically rapid, occurring in a few minutes or hours (see Sections 2.3 and 2.4). This allows the thermodynamically based activity diagrams to be used as a predictive tool for the evaporator's short residence times.

In the past, activity diagrams have been calculated manually which is a tedious process. Often mainframe computers were necessary to solve the simultaneous equilibrium equations. Recently, several software applications have become available to allow the activity diagram calculations and plots to be generated on a personal computer (PC). The one used in this study is called The Geochemist's Workbench (GWB). This application is particularly well suited to the thermodynamic calculations related to the SRS evaporators. The GWB was recently used to analyze the cancrinite/sodalite and sodium diuranate solubilities and stability of the SRS 2H-Evaporator. ${ }^{3}$ The GWB software has the following attributes:

- ability to estimate activity coefficients for high ionic strength solutions such as those in the evaporator

- ability to improve the basis upon which the activity coefficients are estimated

- usage of Lawrence Livermore National Laboratory (LLNL) extensive database for minerals and aqueous species used to model the performance of waste forms in the High Level Waste (HLW) Repository

- includes sodium diuranate and aqueous uranate species as well as most aqueous aluminates and silicates

- ability to calculate the relative stability of multiple solid phases simultaneously

- ability to graphically represent the relative stability of multiple phases in terms of three parameters simultaneouly, e.g. $\mathrm{Si}, \mathrm{Al}$, and $\mathrm{pH}$ of a solution 


\section{WSRC-TR-2000-00293, Rev. 1}

- ability to perform polythermal reaction paths, e.g. reaction path can vary temperature linearly from an initial to a final value so that chemical analyses that are measured at $25^{\circ} \mathrm{C}$ can be evaluated at the elevated tank temperatures $\left(40-60^{\circ} \mathrm{C}\right)$ and elevated evaporator temperatures of $140^{\circ} \mathrm{C}$

- ability to simulate evaporation by removing a percentage of the water from the calculation, e.g. base the calculation on $0.6 \mathrm{~kg}$ of water rather than on the default of $1 \mathrm{~kg}$ of water for a simulated $40 \%$ evaporation

- ability to calculate a supersaturation index for a given solid phase expressed as a ratio of the reaction quotient (Q) over the solubility product (K), e.g. Q/K

- ability to calculate the amount of the solid phase (in $\mathrm{g}_{(\text {solid }} / \mathrm{kg}_{\text {(soln) }}$ ) that will form at the given supersaturation if precipitation to equilibrium proceeds.

Two subroutines in GWB were used to model the precipitation of solids in the complex $\mathrm{Na}-\mathrm{N}-\mathrm{Si}-\mathrm{Al}-\mathrm{U}-\mathrm{H}_{2} \mathrm{O}$ system pertinent to the SRS 2H-Evaporator; e.g. REACT and ACT2. The REACT subroutine models equilibrium states and processes of solids in equilibrium with aqueous fluids. The program calculates the following:

- equilibrium distribution of aqueous species in a fluid

- the fluid's saturation state with respect to mineral phases

- the fugacities of the gases dissolved in the fluid

During the modeling of deposition in the $2 \mathrm{H}$-Evaporator using GWB several mineral phases that were known to kinetically form on geologic time scales, but not on the time scales pertaining to the $2 \mathrm{H}$-Evaporator, the appearance of these phases were suppressed. e.g. high and low albite, montmorillonite. The ACT2 program was used to calculate and plot activity-activity diagrams for representation of the solids precipitation. The manner in which GWB calculates equilibrium $\mathrm{K}_{\mathrm{sp}}$ from solubility data and estimates activity coefficients using the Helgeson B-dot method for high ionic strength solutions such as those in the SRS evaporators is discussed in Appendix A of this report. The degree of supersaturation was developed into a process control algorithm for the operation of all of the SRS evaporators.

The GWB calculations in the complex $\mathrm{Na}-\mathrm{N}-\mathrm{Si}-\mathrm{Al}-\mathrm{U}-\mathrm{H}_{2} \mathrm{O}$ system were validated (Appendix C) by modeling two additional data sets not related to solids deposition in the SRS evaporators. The first of these was the analysis of the M-Area wastes (supernate

\footnotetext{
¥ At $25^{\circ} \mathrm{C}$, analcime, jadeite, K-feldspar, kalsilite, maximum microcline, nepheline and soddyite were suppressed. For NAS diagrams Mixed Zeolite was suppressed while for Mixed Zeolite diagrams, NAS was suppressed. In addition, Zeolite-A and Sodalite- $\mathrm{OH}$ were suppressed. At $120^{\circ} \mathrm{C}$, boehmite, dawsonite, GWB diaspore, GWB gibbsite, kalsilite, nepheline, sodalite- $\mathrm{NO}_{3}$, sodalite- $\mathrm{OH}$, and Zeolite-A were suppressed. For NAS diagrams Mixed Zeolite was suppressed while for Mixed Zeolite diagrams, NAS was suppressed.
} 


\section{WSRC-TR-2000-00293, Rev. 1}

plus sludge) from 1987 when the M-Area tanks were well agitated. ${ }^{10}$ This waste was high in alumina, silica, and sodium nitrate. The tanks were at ambient temperature. The REACT code predicted that the solutions were supersaturated with respect to Zeolite-A, hydroxysodalite, nitrated sodalite, $\mathrm{Na}_{2} \mathrm{U}_{2} \mathrm{O}_{7}$ (sodium diuranate), and $\mathrm{Al}(\mathrm{OH})_{3}$ (gibbsite). The phases identified by $\mathrm{x}$-ray diffraction to have formed in the sludge were Zeolite-A, $\mathrm{Na}_{2} \mathrm{U}_{2} \mathrm{O}_{7}$, and $\mathrm{Al}(\mathrm{OH})_{3}{ }^{10}{ }^{10}$ The second set of confirmatory data was from a study of caustic additions to a highly acidic concentrated uranyl nitrate solution. ${ }^{11}$ The REACT code indicated that a precipitate of schoepite should be in equilibrium with uranyl nitrate in solution. Pierce's solution remained acidic after he started the neutralization, but a precipitate formed that was analyzed by $\mathrm{x}$-ray diffraction to be becquerelite (PDF pattern \#29-0389) a structural isomer of schoepite $\left(\mathrm{UO}_{2} \cdot 2 \mathrm{H}_{2} \mathrm{O}\right) .{ }^{12}$ Both of these independent studies validated that GWB is calculating the activity diagrams and the reactions in this complex system correctly (Appendix C). 


\subsection{Zeolite, Sodalite, and Cancrinite Nomenclature and Paragenesis}

The type of sodalite normally found in nature has the formula $\mathrm{Na}_{8}\left[\mathrm{Al}_{6} \mathrm{Si}_{6} \mathrm{O}_{24}\right]\left(\mathrm{Cl}_{2}\right)$. The square brackets in the formula are used to delineate the alumina:silica ratio of the aluminosilicate cage structure shown in Figure 1. The cavities in the framework are occupied by two sodium and two chlorine ions. ${ }^{13}$ The formula can also be written as $\mathrm{Na}_{6}\left[\mathrm{Al}_{6} \mathrm{Si}_{6} \mathrm{O}_{24}\right] \bullet(2 \mathrm{NaCl})$ to indicate that two $\mathrm{NaCl}$ are in cavities of the cage structure while the remaining Na:Si:Al have a 1:1:1 stoichiometry. ${ }^{13}$ When the $2 \mathrm{NaCl}$ are replaced by $\mathrm{Na}_{2} \mathrm{SO}_{4}, \mathrm{Na}_{2} \mathrm{CO}_{3}, 2 \mathrm{NaNO}_{3}$, and/or $2 \mathrm{NaOH}$, the mineral and/or chemical names are as given in Table I.

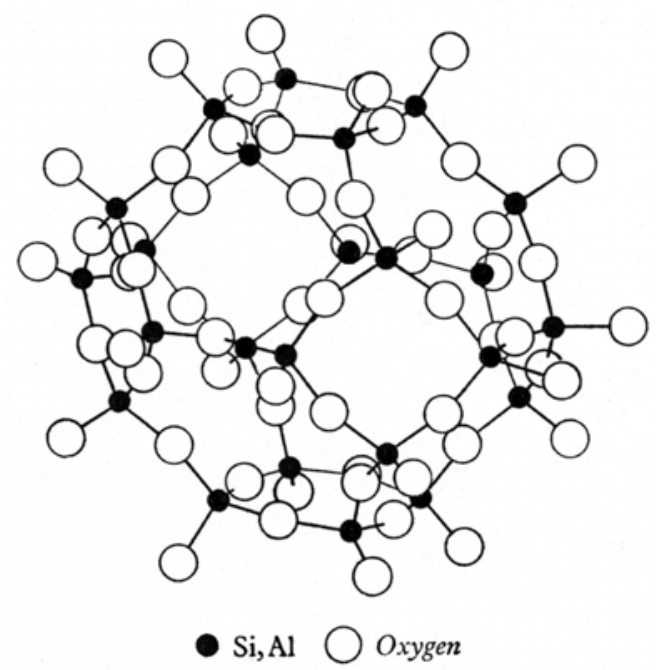

Figure 1. Part of the aluminosilicate framework in the structure of sodalite. ${ }^{13}$

Linde Zeolite-A, $\mathrm{Na}_{12}\left[\mathrm{Al}_{12} \mathrm{Si}_{12} \mathrm{O}_{48}\right] \cdot 27 \mathrm{H}_{2} \mathrm{O}$, is a phase related structurally to basic sodalite and basic nosean ${ }^{19}$ because the alumina:silica ratio of the aluminosilicate cage structure is the same as that found in the sodalites (Figure 1). Zeolite-A is a double unit cell of sodalite without the $\mathrm{NaCl}, \mathrm{Na}_{2} \mathrm{SO}_{4}, \mathrm{NaOH}$, or $\mathrm{Na}_{2} \mathrm{CO}_{3}$ groups inside the cage (Table I).

Recent work at Argonne National Laboratory-West (ANL-W) on sodalite based ${ }^{\dagger}$ waste forms containing $\mathrm{NaCl}$ found that Zeolite-A formed as a precursor to the formation of sodalite, $\mathrm{Na}_{8}\left[\mathrm{Al}_{6} \mathrm{Si}_{6} \mathrm{O}_{24}\right]\left(\mathrm{Cl}_{2}\right) .{ }^{14}$ The Zeolite-A transformed to $\mathrm{Na}_{8}\left[\mathrm{Al}_{6} \mathrm{Si}_{6} \mathrm{O}_{24}\right]\left(\mathrm{Cl}_{2}\right)$ at elevated temperature and pressure. Wilmarth ${ }^{15}$ has determined that a mixture of the nitrated sodalite and nitrated cancrinite found in the $2 \mathrm{H}$-Evaporator also forms from a Zeolite-A precursor while Frederick determined that mixtures of nitrited sodalite and cancrinite found to deposit in spent pulping liquor evaporators also formed from a Zeolite-A precursor. ${ }^{16}$ The studies by Gasteiger, Frederick, et al. ${ }^{17}$ found that a mixture of

\footnotetext{
$\dagger$ waste form is $69 \mathrm{wt} \%$ sodalite, $22 \mathrm{wt} \%$ glass, $2.4 \mathrm{wt} \% \mathrm{NaCl}, 6.7 \mathrm{wt} \%$ nepheline, and $1 \mathrm{wt} \%$ actinides
} 


\section{WSRC-TR-2000-00293, Rev. 1}

sodalite and hydroxysodalite $\left(\mathrm{Na}_{8}\left[\mathrm{Al}_{6} \mathrm{Si}_{6} \mathrm{O}_{24}\right] \mathrm{Cl}_{2}\right.$ and $\left.\mathrm{Na}_{8}\left[\mathrm{Al}_{6} \mathrm{Si}_{6} \mathrm{O}_{24}\right](\mathrm{OH})_{2}\right)$ precipitated in the $[\mathrm{Al}] /[\mathrm{Si}]$ range between 0.076 and 3 where $\mathrm{Al}(\mathrm{OH})_{4}{ }^{-}$and $\mathrm{HSiO}_{4}{ }^{3-}$ were the predominant aluminum and silicon species. These aqueous alkaline solutions had ionic strengths between 1.0 and $4.0 \mathrm{~mol} / \mathrm{kg}$ at $95^{\circ} \mathrm{C}$.

Table I. Structurally Related Zeolite-A, Sodalite,and Cancrinite Group Phases

\begin{tabular}{|c|c|c|c|c|c|}
\hline $\begin{array}{l}\text { Substitution In } \\
\text { Cage Structure }\end{array}$ & Chemical Formula & $\begin{array}{c}\text { Common or Mineral } \\
\text { Name }\end{array}$ & $\begin{array}{l}\text { Density } \\
(\mathrm{g} / \mathrm{cm} 3)\end{array}$ & $\begin{array}{c}\text { Crystal } \\
\text { Type }\end{array}$ & Ref. \\
\hline \multicolumn{6}{|l|}{ Precursor } \\
\hline NONE & $\mathrm{Na}_{12}\left[\mathrm{Al}_{12} \mathrm{Si}_{12} \mathrm{O}_{48}\right] \bullet 27 \mathrm{H}_{2} \mathrm{O}$ & Zeolite-A & $1.99^{\ddagger}$ & Cubic & 18,19 \\
\hline \multicolumn{6}{|l|}{ Sodalite Group } \\
\hline $2 \mathrm{NaCl}$ & $\mathrm{Na}_{6}\left[\mathrm{Al}_{6} \mathrm{Si}_{6} \mathrm{O}_{24}\right](2 \mathrm{NaCl})$ & Sodalite & $2.31^{*}$ & Cubic $^{*}$ & 13 \\
\hline $2 \mathrm{NaOH}$ & $\mathrm{Na}_{6}\left[\mathrm{Al}_{6} \mathrm{Si}_{6} \mathrm{O}_{24}\right](2 \mathrm{NaOH}) \bullet 1.5 \mathrm{H}_{2} \mathrm{O}$ & $\begin{array}{l}\text { Basic Sodalite or } \\
\text { Hydroxysodalite }\end{array}$ & $2.215^{* *}$ & Cubic $^{* *}$ & 19 \\
\hline $2 \mathrm{NaNO}_{3}$ & $\mathrm{Na}_{6}\left[\mathrm{Al}_{6} \mathrm{Si}_{6} \mathrm{O}_{24}\right]\left(2 \mathrm{NaNO}_{3}\right)$ & Nitrated Sodalite & 2.342 & Cubic & $\begin{array}{c}\text { PDF\#50- } \\
0248\end{array}$ \\
\hline $\mathrm{Na}_{2} \mathrm{SO}_{4}$ & $\mathrm{Na}_{6}\left[\mathrm{Al}_{6} \mathrm{Si}_{6} \mathrm{O}_{24}\right]\left(\mathrm{Na}_{2} \mathrm{SO}_{4}\right)$ & Nosean & $2.21^{\mathrm{tt}}$ & Cubic $^{\text {tt }}$ & 12 \\
\hline $\mathrm{xNaOH}+\mathrm{y} \mathrm{H}_{2} \mathrm{O}$ & $\mathrm{Na}_{6}\left[\mathrm{Al}_{6} \mathrm{Si}_{6} \mathrm{O}_{24}\right](\mathrm{xNaOH}) \bullet y \mathrm{H}_{2} \mathrm{O}$ & Basic Nosean & & & 19 \\
\hline $1-2(\mathrm{Ca}, \mathrm{Na}) \mathrm{SO}_{4}$ & $(\mathrm{Na})_{6}\left[\mathrm{Al}_{6} \mathrm{Si}_{6} \mathrm{O}_{24}\right]\left((\mathrm{Ca}, \mathrm{Na}) \mathrm{SO}_{4}\right)_{1-2}{ }^{\mathrm{t}}$ & Hauyne & $2.4^{\mathrm{t}}$ & Cubic $^{t}$ & 12 \\
\hline $\mathrm{x}(\mathrm{Ca}, \mathrm{Na})\left(\mathrm{S}, \mathrm{SO}_{4}, \mathrm{Cl}\right)$ & $(\mathrm{Ca}, \mathrm{Na})_{6}\left[\mathrm{Al}_{6} \mathrm{Si}_{6} \mathrm{O}_{24}\right]\left((\mathrm{Ca}, \mathrm{Na}) \mathrm{S}, \mathrm{SO}_{4}, \mathrm{Cl}\right)_{\mathrm{x}}{ }^{\mathrm{t}}$ & Lazurite & 2.43 & Cubic & $\begin{array}{c}\text { PDF } \\
\# 17-749\end{array}$ \\
\hline \multicolumn{6}{|c|}{ Cancrinite Group } \\
\hline $2 \mathrm{NaNO}_{3}$ & $\mathrm{Na}_{6}\left[\mathrm{Al}_{6} \mathrm{Si}_{6} \mathrm{O}_{24}\right]\left(2 \mathrm{NaNO}_{3}\right) \cdot 4 \mathrm{H}_{2} \mathrm{O}$ & Nitrated Cancrinite & 2.51 & Hexagonal & $\begin{array}{l}\text { PDF \#38- } \\
513\end{array}$ \\
\hline$(\mathrm{Na}, \mathrm{Ca}, \mathrm{K})_{2} \mathrm{CO}_{3}$ & $\begin{array}{c}(\mathrm{Na}, \mathrm{Ca}, \mathrm{K})_{6}\left[\mathrm{Al}_{6} \mathrm{Si}_{6} \mathrm{O}_{24}\right]\left((\mathrm{Na}, \mathrm{Ca}, \mathrm{K})_{2} \mathrm{CO}_{3}\right)_{1} \\
{ }_{6}^{\bullet} 2.1 \mathrm{H}_{2} \mathrm{O}\end{array}$ & Cancrinite & 2.60 & Hexagonal & $\begin{array}{l}\text { PDF \#25- } \\
776\end{array}$ \\
\hline $2(\mathrm{Na}, \mathrm{K}) \mathrm{Cl}$ & $(\mathrm{Na}, \mathrm{Ca}, \mathrm{K})_{6}\left[\mathrm{Al}_{6} \mathrm{Si}_{6} \mathrm{O}_{24}\right](2(\mathrm{Na}, \mathrm{K}) \mathrm{Cl})_{2-3}$ & Microsommite & 2.34 & Hexagonal & $\begin{array}{c}\text { PDF } \\
\# 20-743\end{array}$ \\
\hline $2(\mathrm{Na}, \mathrm{K}) \mathrm{Cl}$ & $(\mathrm{Na}, \mathrm{Ca}, \mathrm{K})_{6}\left[\mathrm{Al}_{6} \mathrm{Si}_{6} \mathrm{O}_{24}\right]\left((\mathrm{Na}, \mathrm{K})_{2} \mathrm{SO}_{4}, \mathrm{Cl}\right)_{3}$ & Davyne & 2.46 & Hexagonal & $\begin{array}{c}\text { PDF } \\
\# 20-379\end{array}$ \\
\hline $\mathrm{Na}_{2} \mathrm{CO}_{3}$ & $\mathrm{Na}_{6}\left[\mathrm{Al}_{6} \mathrm{Si}_{6} \mathrm{O}_{24}\right]\left(\mathrm{Na}_{2} \mathrm{CO}_{3}\right)$ & Natrodavyne & $\begin{array}{l}\text { Not } \\
\text { given }\end{array}$ & Hexagonal & $\begin{array}{c}\text { PDF } \\
\# 15-794\end{array}$ \\
\hline $\begin{array}{l}\mathrm{t} \\
\mathrm{tt}\end{array}$ & $\begin{array}{l}\text { PDF \#20-1087 } \\
\text { PDF \#17-538 }\end{array}$ & $\begin{array}{l}\text { PDF \# 20-495 } \\
\text { PDF \#11-401 }\end{array}$ & F \#11- & nd \#38-24 & \\
\hline
\end{tabular}

The formation of Zeolite-A is well studied and very rapid kinetically. Formation from a sodium aluminate gel (87 wt $\% \mathrm{NaAlO}_{2}$ and $13 \mathrm{wt} \% \mathrm{NaOH}$ commercially available as Alfloc) and a $1 \mathrm{M}$ colloidal silica sol (particles of $250 \AA$ ) formed well crystallized ZeoliteA (also called Zeolite Q by Barrer, et. al. ${ }^{19}$ ) at temperatures between $85-110^{\circ} \mathrm{C}$ at $\mathrm{pH}$ values $\geq 10$ in 2 or 3 hours (longer residence times were needed if the silica content of the gel increased and crystallization was more rapid in the presence of excess $\mathrm{NaOH}$ ). ${ }^{19,20}$

Zeolite-A $\left(\mathrm{Na}_{12} \mathrm{Al}_{12} \mathrm{Si}_{12} \mathrm{O}_{48} \bullet 27 \mathrm{H}_{2} \mathrm{O}\right)$ had also been found to form in the SRS M-Area waste tanks at ambient temperature. ${ }^{10}$ Zeolite was found to form preferentially in tanks with high $\mathrm{pH}(12-12.8)$ when sufficient $\mathrm{Al}(\mathrm{OH})_{3}$ was present. Since no zeolite had been used in any M-Area processes, experiments were performed ${ }^{10}$ to determine how ZeoliteA got into the tanks. These experiments demonstrated that the zeolite could form rapidly from the interaction of high surface area filter aids in the tank (perflo and diatomaceous 


\section{WSRC-TR-2000-00293, Rev. 1}

earth $\$$ ). Sodalite formed when the filter aids were placed in $6 \mathrm{M} \mathrm{NaOH}$ at room temperature for 29 hours at a $\mathrm{pH}$ of 13.73.

As indicated above the Zeolite-A structure can form (1) from a hydrogel process where the reactants are reactive oxides, soluble silicates, and soluble aluminates in a caustic solution; (2) from conversion of clay minerals (specifically kaolin and meta-kaolin) in the presence of soluble silicates and caustic; or (3) by reaction of silica sols, natural $\mathrm{SiO}_{2}$, amorphous minerals, and volcanic glass in the presence of caustic. ${ }^{3}$ The hydrogel reactions are of the type:

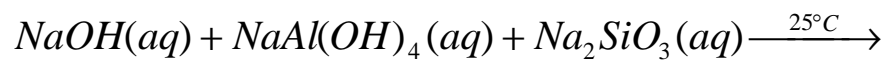

$$
\begin{aligned}
& {\left[\mathrm{Na}_{a}\left(\mathrm{AlO}_{2}\right)_{b}\left(\mathrm{SiO}_{2}\right)_{c} \bullet \mathrm{NaOH} \bullet \mathrm{H}_{2} \mathrm{O}\right]_{\text {gel }} \stackrel{25-175^{\circ} \mathrm{C}}{\text { hydrothernal }} \longrightarrow \mathrm{Na} a_{x}\left[\left(\mathrm{AlO}_{2}\right)_{x}\left(\mathrm{SiO}_{2}\right)_{y}\right] \bullet \mathrm{mH}_{2} \mathrm{O}}
\end{aligned}
$$

Zeolites are synthesized industrially using the hydrogel process shown in Equation 1. Upon mixing sodium silicate and sodium aluminate at high $\mathrm{pH}$ an amorphous sodium aluminosilicate gel phase forms which will be abbreviated as $\mathrm{NAS}_{\text {gel }}$. Transformation of the gel to the zeolite can take hours or days depending upon the synthesis conditions. Industrial synthesis of Zeolite-A involves the use of solutions with $4.0 \mathrm{M} \mathrm{NaOH}$ concentrations to keep the crystallization times short and allow effective recycling of the excess $\mathrm{NaOH}^{21}$ The dissolution of Zeolite-A has been studied by numerous investigators including Gasteiger, et. al. ${ }^{17}$ but these investigations have been at insufficiently high $\mathrm{NaOH}$ concentrations to be relevant to industrial zeolite synthesis. ${ }^{22}$ Recently, Ejaz et. al. $^{22}$ studied the solubility of Zeolite-A and its amorphous precursor $\left(\mathrm{NAS}_{\text {gel }}\right)$ in solutions between 3.0-4.4M NaOH at temperatures of $30-80^{\circ} \mathrm{C}$. The composition of the precursor gel at $\mathrm{NaOH}$ concentrations of $3-4.5 \mathrm{M}$ was determined experimentally to be $0.93 \mathrm{Na}_{2} \mathrm{O}: 1 \mathrm{Al}_{2} \mathrm{O}_{3}: 2.32 \mathrm{SiO}_{2}: 5.15 \mathrm{H}_{2} \mathrm{O}$.

Gels are amorphous as they are colloids in which the disperse phase has combined with the continuous phase to produce a semisolid material such as a jelly. ${ }^{23}$ As a gel dewaters or ages it will form a denser gel and/or a crystalline solid phase. This is independent of the route of formation of the gel. Whether the $\mathrm{NAS}_{\text {gel }}$ forms from solution via a hydrogel process or whether it forms from a sol (solid particles in liquid) ${ }^{24}$ via a sol-gel process, the aging sequence of the NAS gel $_{\text {e }}$ to denser sodalite and still denser cancrinite type species will typically follow an aging path such as that shown in Figure 2 according to Barnes, Mensah and Gerson ${ }^{25}$ and Gerson and Zheng. ${ }^{26}$ Note that the densification of the phases follows the densities given in Table I and agrees with the following literature:

- Bayer $^{19}$ and $\mathrm{Ejaz}^{22}$ found that the NAS hydrogels would transform to Zeolite-A,

\$ perflo $=\mathrm{K}_{0.08} \mathrm{Na}_{0.08} \mathrm{Al}_{0.16} \mathrm{Si}_{0.81} \mathrm{O}_{1.94}$ and diatomaceous earth $=\mathrm{K}_{0.06} \mathrm{Na}_{0.06} \mathrm{Al}_{0.18} \mathrm{Si}_{0.61} \mathrm{O}_{1.55} \bullet 0.22 \mathrm{H}_{2} \mathrm{O}$. 


\section{WSRC-TR-2000-00293, Rev. 1}

- $\quad$ Barrer $^{19}$ found that the NAS hydrogels would transform to Zeolite-A at $\mathrm{pH}$ values $>10$ in $2-3$ hours at $110^{\circ} \mathrm{C}$ (the approximate temperature of the $2 \mathrm{H}$ Evaporator),

- Buhl and Lons ${ }^{27}$ showed that nitrated sodalite and nitrated cancrinite could best be made by starting with a Zeolite-A precursor in concentrated $\mathrm{NaOH}$ at various temperatures,

- Wilmarth ${ }^{28}$ showed that the Zeolite-A forms as a precursor but the nitrated cancrinite forms on the order of $3-5$ hours at $110^{\circ} \mathrm{C}$ in simulated $2 \mathrm{H}$ Evaporator solutions,

- Gasteiger et al. ${ }^{17}$ found that basic sodalite $\mathrm{Na}_{8}\left[\mathrm{Al}_{6} \mathrm{Si}_{6} \mathrm{O}_{24}\right](\mathrm{OH})_{2} \bullet\left(1.5 \mathrm{H}_{2} \mathrm{O}\right)$ and sodalite $\left(\mathrm{Na}_{8}\left[\mathrm{Al}_{6} \mathrm{Si}_{6} \mathrm{O}_{24}\right](\mathrm{Cl})_{2}\right)$ formation was $>99 \%$ complete in 24 hours at $95^{\circ} \mathrm{C}$ and that the sodalites formed via a Zeolite-A precursor,

- Subotic, et. al. ${ }^{29}$ demonstrated that aluminosilicate gels that have a $\mathrm{Si} / \mathrm{Al}=1$ form Zeolite-A at lower $\mathrm{NaOH}$ concentrations in solution at $85^{\circ} \mathrm{C}$ which then transforms into hydroxysodalite; at higher $\mathrm{NaOH}$ concentrations the gel can transform into hydroxysodalite without the Zeolite-A precursor formation, and

- Bosnar and Subotic ${ }^{30}$ demonstrated that Zeolite-A forms from an amorphous aluminosilicate precursor $\left(1.03 \mathrm{Na}_{2} \mathrm{O}: \mathrm{Al}_{2} \mathrm{O}_{3}: 2.38 \mathrm{SiO}_{2}: 1.66 \mathrm{H}_{2} \mathrm{O}\right)$ and the Zeolite-A growth is governed by the Davies-Jones model of growth and dissolution (growth of Zeolite A from solution coupled with dissolution of the amorphous phase); growth rate decreases with increasing alkalinity.

Note that the amorphous aluminosilicate gel precursor of Ejaz ${ }^{22}$

$\left(0.93 \mathrm{Na}_{2} \mathrm{O}: 1 \mathrm{Al}_{2} \mathrm{O}_{3}: 2.32 \mathrm{SiO}_{2}: 5.15 \mathrm{H}_{2} \mathrm{O}\right)$ is very similar but not identical to that reported by Bosnar and Subotic ${ }^{30}\left(1.03 \mathrm{Na}_{2} \mathrm{O}: \mathrm{Al}_{2} \mathrm{O}_{3}: 2.38 \mathrm{SiO}_{2}: 1.66 \mathrm{H}_{2} \mathrm{O}\right)$.

It is highly unlikely that the uranium contained in the $2 \mathrm{H}$-Evaporator deposits is incorporated into the cage structure of the Zeolite-A and/or the cancrinite/sodalite phases. The ion exchange capacity of $\mathrm{Na}^{+}$in the Zeolite-A structure for large monovalent ions is minimal, e.g., $\mathrm{Cs}^{+}$and $\mathrm{Rb}^{+}$exchanged at $90^{\circ} \mathrm{C} \sim 31 \%$ and $36 \%$, respectively. ${ }^{31}$ Ion exchange with multivalent cations is limited with ions such as $\mathrm{Ba}^{2+}, \mathrm{Fe}^{2+}$, and $\mathrm{Fe}^{3+}$ exchanging but destroying the zeolite structure while large trivalent cations such as $\mathrm{Ce}^{3+}$ do not exchange at all. ${ }^{31}$ This implies that large tetra- or hexa-valent cations which are most likely tied up in uranium complexes cannot ion exchange for $\mathrm{Na}^{+}$in the Zeolite-A and/or the cancrinite/sodalite structures. In alkaline solution the uranium is more likely to be present as complexes such as $\mathrm{UO}_{2}^{2+}, \mathrm{UO}_{2}(\mathrm{OH})_{4}^{2-}$, and $\mathrm{UO}_{2}(\mathrm{OH})_{5}^{3-}$ which are too large to fit into the cage structure of the aluminosilicates. This is in agreement with the following:

- the absence of any uranium containing sodalite or cancrinite structures in nature $^{13}$ 
- the absence of uranium in the sodalite phase of the ANL-W sodalite waste form ${ }^{14}$

- the presence of a second uranium-containing phase in the X-ray spectra of the 2 H-Evaporator deposits. ${ }^{1,2,4}$

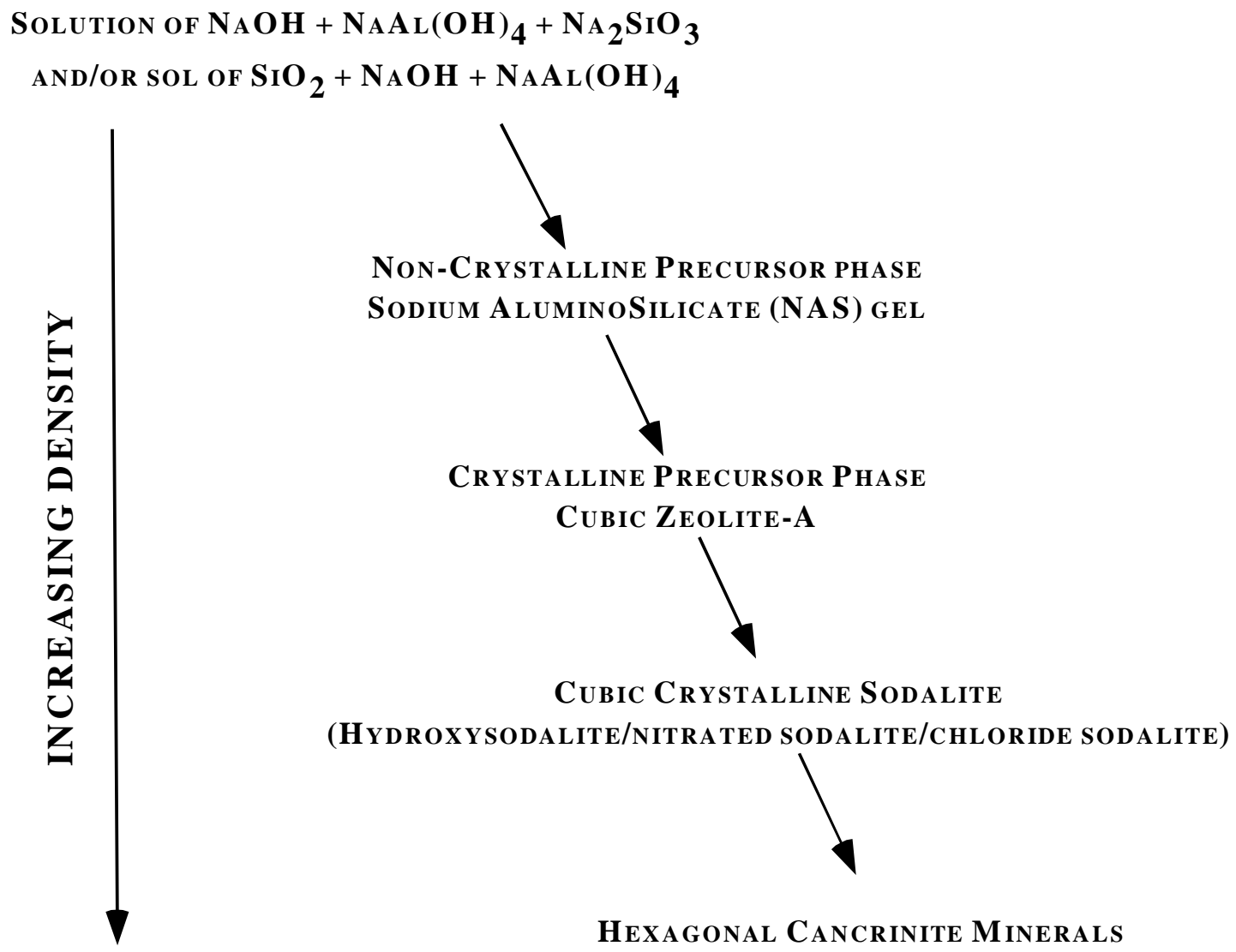

Figure 2. Typical aging (densification) sequence of $\mathrm{NAS}_{\text {gel }} \rightarrow$ Zeolite-A $\rightarrow$ sodalite $\rightarrow$ cancrinite phases depending on the relative concentration of $\mathrm{OH}^{-}, \mathrm{Cl}^{-}, \mathrm{NO}_{3}{ }^{-}$, and/or $\mathrm{CO}_{3}{ }^{=}$in the solution in contact with the $\mathrm{NAS}_{\text {gel }}$ (after Gerson, et.al.) ${ }^{25,26}$ 


\subsection{Uranium Phase Paragenesis}

The uranium-containing phase observed in the $2 \mathrm{H}$-Evaporator is sodium diuranate $\left(\mathrm{Na}_{2} \mathrm{U}_{2} \mathrm{O}_{7}\right)$. Sodium diuranate can form readily from mixtures of $0.1 \mathrm{~N}$ uranyl nitrate and $\mathrm{NaOH}$ at room temperature in time frames of $<24$ hours. The ratio of the Na:U in the polyuranate phase that forms is a function of $\mathrm{pH}$ of the solution and the length of time that the $\mathrm{Na}$ has to diffuse into the crystal structure. ${ }^{32}$ Specifically, when $\mathrm{NaOH}$ was added to dilute solutions of uranyl nitrate, the first species to form was a polymerized ion of the form $\left[\mathrm{UO}_{2}\left(\mathrm{UO}_{3} \mathrm{H}_{2} \mathrm{O}\right)_{\mathrm{n}}\right]^{++}$, followed by precipitation of a nitrated uranate phase with a polymer chain of $\left[\left(\mathrm{UO}_{3} \mathrm{H}_{2} \mathrm{O}\right)_{5} \mathrm{~N}_{2} \mathrm{O}_{5}\right]$ at $\mathrm{pH}$ of $4 .{ }^{32}$ As the solution $\mathrm{pH}$ increases with increasing $\mathrm{NaOH}, \mathrm{Na}_{2} \mathrm{O}$ replaces the $\mathrm{N}_{2} \mathrm{O}_{5}$ in the polymer chain forming $\left[\left(\mathrm{UO}_{3} \mathrm{H}_{2} \mathrm{O}\right)_{\mathrm{n}} \mathrm{Na}_{2} \mathrm{O}\right]$ where $\mathrm{n}$ changes from 16 at low $\mathrm{pH}$ values to 5 at higher $\mathrm{pH}$ values. Longer contact with the $\mathrm{NaOH}$ rich solution at high $\mathrm{pH}$ causes $\mathrm{n}$ to become $\leq 3$ causing a change in the crystal structure. At $\mathrm{n}=2$ the final stable $\mathrm{Na}_{2} \mathrm{U}_{2} \mathrm{O}_{7} \cdot 2 \mathrm{H}_{2} \mathrm{O}$ composition is formed. Similar results were observed when reactive $\mathrm{UO}_{3}$ was treated with $\mathrm{NaOH}$ at $50^{\circ} \mathrm{C}$ and $75^{\circ} \mathrm{C} .{ }^{33}$ It should be noted that in both of these studies ${ }^{32,33}$ the $\mathrm{Na}_{2} \mathrm{U}_{2} \mathrm{O}_{7}$ precipitates were very small and suspended in the $\mathrm{NaOH}$ solutions, i.e., the precipitates had to be centrifuged in order to be examined. Finely dispersed sodium diuranate phases were found to form readily at $25^{\circ} \mathrm{C}$ in about 10-60 minutes, ${ }^{32}$ reaching equilibrium in about 5 days. 34

Hobbs and Karraker ${ }^{35}$ studied the precipitation of $\mathrm{Na}_{2} \mathrm{U}_{2} \mathrm{O}_{7}$ in simulated evaporator solutions under simulated evaporator conditions. The precipitates that formed had particle size ranges between $3.3 \mu \mathrm{m}$ and $60 \mu \mathrm{m}$ for unsaturated solutions and $2.3 \mu \mathrm{m}$ to $13 \mu \mathrm{m}$ for supersaturated solutions. The studies indicated that $\mathrm{Na}_{2} \mathrm{U}_{2} \mathrm{O}_{7}$ would precipitate under evaporator conditions and might accumulate depending on particle size, mixing, and equipment geometry. The accumulation of $\mathrm{Na}_{2} \mathrm{U}_{2} \mathrm{O}_{7}$ with the nitrated zeolite in the $2 \mathrm{H}$-Evaporator is likely caused by surface attraction. Precipitation of uranium and not other salts (e.g. sodium sulfate, sodium carbonate, etc) would be expected, as the solubility of uranium is much lower than that of the other salt components.

$\$ \quad$ Note that the equilibrium constant can be calculated for reactions of the type given in Equations 2, 5, and 7 from the relationship $\Delta \mathrm{G}^{\circ}=-\mathrm{RT} \ln \mathrm{K}_{\text {eq }}$, where $\mathrm{R}$ is the gas constant $\left(1.987 \times 10^{-3}\right.$

$\mathrm{kcal} / \mathrm{mol} / \mathrm{K}$ ), $\mathrm{T}=$ degrees Kelvin, and $\Delta \mathrm{G}^{\circ}=\sum \Delta \mathrm{G}_{\mathrm{f} \text { (products) }}-\sum \Delta \mathrm{G}_{\mathrm{f} \text { (reac tan ts) }}$. 


\subsection{Amorphous Aluminate Phase Paragenesis}

Two crystalline phases, a sodium aluminosilicate and a sodium diuranate were identified in the SRS 2H-Evaporator. These phases were found in the SRS 2H-Evaporator pot, ${ }^{1}$ in the gravity drain line (GDL), ${ }^{4}$ and on the evaporator pot walls. ${ }^{2}$ Wilmarth chemically analyzed the deposits forming in the $\operatorname{pot}^{1}$ and on the walls. ${ }^{4}$ There was insufficient sample from the GDL to perform a complete chemical analysis. A mass balance was performed in this study (Table II) of the chemical analyses for the evaporator pot and wall deposits. The mass balance was performed to determine (1) the relative amounts of the nitrated sodalite and the sodium diuranate phases and (2) to determine if other amorphous species were present in these deposits. The latter was needed (1) to understand the equilibria between crystalline and amorphous deposits in order to represent them properly on the activity diagrams and (2) to determine if $\mathrm{Al}(\mathrm{OH})_{3}$ could be present and be related to the deposition of deposits on the evaporator walls, e.g., deposition of $\mathrm{Al}(\mathrm{OH})_{3}$ adhering to the walls of the M-Area sludge tanks, which had previously been documented. ${ }^{10}$

All of the data presented in the Wilmarth studies as $\mathrm{mg} / \mathrm{L}$ were converted to element wt\%. All of the elemental uranium was speciated as $\mathrm{Na}_{2} \mathrm{U}_{2} \mathrm{O}_{7}$ on a molar basis and then converted back into sodium uranate on a wt $\%$ basis (A model calculation is given in Appendix D.) A corresponding amount of $\mathrm{Na}(\mathrm{wt} \%)$ was removed from the total amount of elemental $\mathrm{Na}(\mathrm{wt} \%$ ) available to all other phases present. Ideally, the amount of nitrated cancrinite $\left.\left(\mathrm{Na}_{8} \mathrm{Al}_{6} \mathrm{Si}_{6} \mathrm{O}_{24}\left(\mathrm{NO}_{3}\right)_{2}\right) \bullet 4 \mathrm{H}_{2} \mathrm{O}\right)$ should have been calculated from the analyzed nitrate concentration but $\mathrm{NO}_{3}{ }^{-}$analyses had not been performed. If the amount of nitrated cancrinite $\left(\mathrm{Na}_{8} \mathrm{Al}_{6} \mathrm{Si}_{6} \mathrm{O}_{24}\left(\mathrm{NO}_{3}\right)_{2}\right) \bullet 4 \mathrm{H}_{2} \mathrm{O}$ was calculated based on the $\mathrm{Na}$ (wt\%) remaining after speciation with $\mathrm{Na}_{2} \mathrm{U}_{2} \mathrm{O}_{7}$, then there was a significant deficit of $\mathrm{SiO}_{2}$. The amount of nitrated cancrinite was, therefore, calculated based on the amount of Si (wt\%). This left an excess of two elements, $\mathrm{Al}(\mathrm{wt} \%)$ and $\mathrm{Na}(\mathrm{wt} \%)$ in which could be speciated as $\mathrm{NaAlO}_{2}$ if the two elements were present in equilvalent molar concentrations. However, the two elements were not present in equivalent molar concentrations so the $\mathrm{Al}(\mathrm{wt} \%)$ was speciated as amorphous $\mathrm{Al}(\mathrm{OH})_{3}$ and the $\mathrm{Na}(\mathrm{wt} \%)$ as $\mathrm{NaOH}$.

The sums of the mass balance varied from 72.69 to 130.75 with one analysis (Wall sample \#3) totaling to approximately $100 \%$. This indicated that some of the analyses were biased high and some were biased low in $\mathrm{Al}$ and $\mathrm{Si}$, while one was fairly accurate and totaled to almost $100 \%$. Sums of $100 \pm 5 \mathrm{wt} \%$ are considered accurate for a mass balance calculation. ${ }^{39}$ Assuming that the analytic biases were either a weighing or dilution error affecting the entire analysis provided the basis for normalizing the wt $\%$ of each phase (Table II). Once the mass balances of the six samples are normalized it becomes apparent that each sample contained $\sim 25 \mathrm{wt} \%$ amorphous $\mathrm{Al}(\mathrm{OH})_{3}$ and $62-68$ $\mathrm{wt} \%$ nitrated sodalite/cancrinite. The mass balance also showed that there was approximately twice the amount of $\mathrm{Na}_{2} \mathrm{U}_{2} \mathrm{O}_{7}$ in the evaporator pot than on the walls. The mass balance indicated that the critical equilibrium to be modeled is that between $\mathrm{Al}(\mathrm{OH})_{3}$ (gibbsite) and the nitrated sodalite/cancrinite. 
Table II. Mass Balance of Evaporator Wall and Pot Deposits

\begin{tabular}{|c|c|c|c|c|c|c|}
\hline SPECIES (wt\%) & $\begin{array}{c}\text { Wall } \\
\# 1\end{array}$ & $\begin{array}{c}\text { Wall } \\
\# 2\end{array}$ & $\begin{array}{c}\text { Wall } \\
\# 3\end{array}$ & $\begin{array}{c}\text { Pot } \\
\# 1\end{array}$ & $\begin{array}{c}\text { Pot } \\
\# 2\end{array}$ & $\begin{array}{c}\text { Pot } \\
\# 3\end{array}$ \\
\hline \multicolumn{7}{|l|}{ Raw Analyses } \\
\hline $\mathrm{Al}(\mathrm{OH})_{3}$ & 31.28 & 31.51 & 22.87 & 17.45 & 16.98 & 17.68 \\
\hline $\mathrm{NaOH}$ & 0.58 & 0.60 & 0.54 & 0.61 & 0.53 & 0.58 \\
\hline $\mathrm{Na}_{2} \mathrm{U}_{2} \mathrm{O}_{7}$ & 7.86 & 7.86 & 7.73 & 9.07 & 9.52 & 9.49 \\
\hline $\mathrm{Na}_{8} \mathrm{Al}_{6} \mathrm{Si}_{6} \mathrm{O}_{24}\left(\mathrm{NO}_{3}\right)_{2} \bullet 4 \mathrm{H}_{2} \mathrm{O}$ & 88.30 & 90.81 & 66.72 & 45.90 & 45.67 & 46.28 \\
\hline SUM & 127.99 & 130.75 & 97.83 & 73.01 & 72.69 & 74.01 \\
\hline \multicolumn{7}{|l|}{ Normalized Analyses } \\
\hline $\mathrm{Al}(\mathrm{OH})_{3}$ & 24.43 & 24.09 & 23.37 & 23.89 & 23.36 & 23.88 \\
\hline $\mathrm{NaOH}$ & 0.45 & 0.46 & 0.55 & 0.84 & 0.73 & 0.78 \\
\hline $\mathrm{Na}_{2} \mathrm{U}_{2} \mathrm{O}_{7}$ & 6.14 & 6.01 & 7.90 & 12.42 & 13.09 & 12.82 \\
\hline $\mathrm{Na}_{8} \mathrm{Al}_{6} \mathrm{Si}_{6} \mathrm{O}_{24}\left(\mathrm{NO}_{3}\right)_{2} \bullet 4 \mathrm{H}_{2} \mathrm{O}$ & 68.97 & 69.44 & 68.18 & 62.85 & 62.82 & 62.52 \\
\hline SUM & 100.00 & 100.00 & 100.00 & 100.00 & 100.00 & 100.00 \\
\hline
\end{tabular}

The choice of $\mathrm{Al}(\mathrm{OH})_{3}$ (gibbsite) as the most likely alumina phase in the SRS $2 \mathrm{H}$ Evaporator deposits was based on the similarity of the evaporator chemistry to the chemistry in the M-Area waste tanks. ${ }^{10}$ The M-Area supernate chemistry was very similar to the evaporator supernates, e.g. high in $\mathrm{Al}^{3+}, \mathrm{U}^{6+}$ and $\mathrm{Si}^{4+}$, and $\mathrm{NaNO}_{3}$. Tank $\mathrm{pH}$ values were in the 9.6-12.9 range, somewhat lower than the evaporator supernates. The M-Area slurries, aged in the tanks for $\sim 10$ years at ambient temperatures, precipitated crystalline $\mathrm{Al}(\mathrm{OH})_{3}$ (gibbsite), $\mathrm{Na}_{2} \mathrm{U}_{2} \mathrm{O}_{7}$, and Zeolite- $\mathrm{A}\left(\mathrm{Na}_{12} \mathrm{Al}_{12} \mathrm{Si}_{12} \mathrm{O}_{48} \bullet 27 \mathrm{H}_{2} \mathrm{O}\right)$ when constant agitation was stopped. These solid phases are the same phases found to precipitate in the SRS 2H-Evaporator. In addition, Gasteiger et. al. ${ }^{17}$ found excess $\mathrm{Al}$ in their $\mathrm{Na}_{8}\left[\mathrm{Al}_{6} \mathrm{Si}_{6} \mathrm{O}_{24}\right]\left(\mathrm{Cl}_{2}\right)$ sodalite deposits by chemical analysis when the $[\mathrm{Al}] /[\mathrm{Si}]$ ratio was $\sim 250$. Since there were no additional crystalline species identified by x-ray diffraction other than the sodalite, it was hypothesized that amorphous $\mathrm{Al}(\mathrm{OH})_{3}$ had formed along with the sodalite. This was also in agreement with previous work by Breuer et al. ${ }^{40}$, who formed both sodalite $\left.\mathrm{Na}_{8}\left[\mathrm{Al}_{6} \mathrm{Si}_{6} \mathrm{O}_{24}\right]\left(\mathrm{Cl}_{2}\right)\right)$ and crystalline gibbsite $\left(\mathrm{Al}(\mathrm{OH})_{3}\right)$ at high $[\mathrm{Al}] /[\mathrm{Si}]$ ratios. The mass balance could also have been performed assuming amorphous $\mathrm{AlOOH}$ (diaspore) which is the stable species predicted to form at $120^{\circ} \mathrm{C}$.

\subsection{Adherence of Deposits}

Solid oxides in aqueous solutions are generally electrically charged, as may be observed most directly in electrophoresis experiments. The charge is attributed to one of two indistinguishable mechanisms: (a) amphoteric dissociation of surface $\mathrm{MOH}$ groups and/or (b) adsorption of metal hydroxo complexes derived from the hydrolysis products of material dissolved from the solid oxide. ${ }^{41}$ Particles with diameters less than about $1 \mu \mathrm{m}$ $\left(10^{-6} \mathrm{~m}\right.$ or $\left.1000 \AA\right)$ have a significant percentage of their atoms at particle surfaces. At such sizes and smaller (in the colloidal range, $10^{-8}$ to $10^{-5} \mathrm{~m}$ ) particles have important 14 


\section{WSRC-TR-2000-00293, Rev. 1}

surface properties, whereas larger particles generally do not. Such surface properties can (1) increase the solubilities of small particles, (2) cause the particles to remain in stable suspension (sols), and (3) give the particles a significant unsatisfied surface charge that is related to their colloidal behavior. This surface charge also makes the particles potential sorbents for dissolved species in water. It should be noted that most amorphous silica

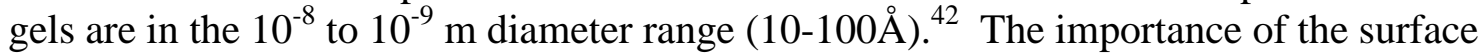
properties of a given weight of colloid or precipitate in solution increases in proportion to the surface area of that material and to its surface charge (or site) density, i.e., the number of charged sites per unit area or weight. Amorphous silica gels have estimated surface areas of 53,292 $\mathrm{m}^{2} / \mathrm{g}$ while $\mathrm{Al}(\mathrm{OH})_{3}$ (gibbsite) has an estimated surface area of only 120

$\mathrm{m}^{2} / \mathrm{g}$. ${ }^{42}$ Silica gel and $\mathrm{Al}(\mathrm{OH})_{3}$ (gibbsite) have equivalent surface-site densities of 4.5-12 sites $/ \mathrm{nm}^{2}$ and 2 to 12 sites $/ \mathrm{nm}^{2}$, respectively. ${ }^{42}$

While the sodium diuranate $\left(\mathrm{Na}_{2} \mathrm{U}_{2} \mathrm{O}_{7}\right)$ phase is associated with the sodalite precipitation in the SRS 2H-Evaporator deposits, there is no evidence that uranium is trapped within the sodalite cage structure (see Section 2.3, last paragraph). There is some evidence from the research at $\mathrm{ANL}-\mathrm{W}$ that $\mathrm{UO}_{2}$ and $\mathrm{PuO}_{2}$ species are attracted to the surface of the zeolite(sodalite) phase in their waste form, but not incorporated into the zeolite(sodalite) structure. ${ }^{14}$ Silicate mineral surfaces usually ${ }^{41}$ have a negative surface charge (zeta potential) in basic solutions while uranium colloids of $70 \AA^{43}$ have a positive surface charge. It may even be likely that the sodalite or the precursor gel adsorbs the polymerized $\left[\mathrm{UO}_{2}\left(\mathrm{UO}_{3} \mathrm{H}_{2} \mathrm{O}\right)_{\mathrm{n}}\right]^{++}$chains (precursors to the more stable $\left.\mathrm{Na}_{2} \mathrm{U}_{2} \mathrm{O}_{7}\right)$ as surface complexes. ${ }^{44,45}$ This suggests that the uranate phase may flocculate together with the zeolite phase due to either zeta potential forces which cause the two separate phases to be attracted to each other or due to adsorption of surface complexes,. Alternatively, the $\mathrm{Na}_{2} \mathrm{U}_{2} \mathrm{O}_{7}$ phase may just be carried along with the copious amounts of sodalite being formed.

One mechanism by which the deposits may adhere to the evaporator walls can be hypothesized based on the findings of $\mathrm{Al}(\mathrm{OH})_{3}$ (gibbsite) deposits in the 304L stainless steel tanks in M-Area after the tanks were emptied. ${ }^{10}$ As pointed out in Section 2.5, the chemistry of the M-Area supernate and the SRS 2H-Evaporator supernates are very similar, high $\mathrm{Al}^{3+}$, high $\mathrm{NaNO}_{3}$, high $\mathrm{Si}^{4+}$, and $\sim 6 \mathrm{wt} \% \mathrm{U}^{6+}$. Most M-Area tank $\mathrm{pH}$ values were in the $11 \pm 0.5$ range. All of the same phases that precipitated from the supernate into the M-Area sludge are the same phases currently forming in the SRS $2 \mathrm{H}$ Evaporator: $\mathrm{Al}(\mathrm{OH})_{3}$ (gibbsite), $\mathrm{Na}_{2} \mathrm{U}_{2} \mathrm{O}_{7}$, and Zeolite- $\mathrm{A}\left(\mathrm{Na}_{12} \mathrm{Al}_{12} \mathrm{Si}_{12} \mathrm{O}_{48} \cdot 27 \mathrm{H}_{2} \mathrm{O}\right)$. In the $\mathrm{M}$-Area tanks the $\mathrm{Al}(\mathrm{OH})_{3}$ had crystallized into gibbsite (long residence times at low temperature) while in the evaporator the aluminate phase appears to be amorphous (short residence times at higher temperatures). The only M-Area tanks that did not precipitate were two tanks in which the $\mathrm{pH}$ stayed between 8 and 9 in conjunction with the fact that the $\mathrm{Al}$ concentration in these two tanks was 4-5 times lower than in all the other tanks.

When the M-Area tanks were emptied, deposits were found attached to the tank wall. The tanks were rinsed with a 35,000 psi water jet but a thin film of the deposits was still attached to the tank wall. The adherent film from the M-Area tanks was analyzed by XRD. The major component was $\mathrm{Al}(\mathrm{OH})_{3}$ (gibbsite). The XRD spectra also showed minor quantities of $\mathrm{NaNO}_{3}$ and magnetite $\left(\mathrm{FeO} \cdot \mathrm{Fe}_{2} \mathrm{O}_{3}\right)$. The findings of an iron oxide in 


\section{WSRC-TR-2000-00293, Rev. 1}

the XRD spectra indicated that the analyzed film contained alumina from the waste and Fe reaction products from oxidation of the metallic iron in the steel. The tenacity of the deposits to the tank wall indicated that the $\mathrm{Al}(\mathrm{OH})_{3}$ was very strongly bonded to the steel.

Adherent bonding of films and deposits can result from electrostatic attractions between different chemical compounds. The chemical bonding of dissolved solids in an aqueous environment to a solid surface can also be related to the zeta potential of the different compounds. ${ }^{42}$ As the tank walls $\left(\mathrm{Fe}^{\circ}\right)$ react with water and nitrate compounds in the waste, the metal in the surface layer of the tank wall gets oxidized to $\mathrm{Fe}^{2+}$, as $\mathrm{Fe}(\mathrm{OH})^{+}$, $\mathrm{Fe}(\mathrm{OH})_{2}$, or $\mathrm{FeO}$ or even ferrihydrite $\left(\mathrm{Fe}(\mathrm{OH})_{3} \bullet n \mathrm{H}_{2} \mathrm{O}\right)$. $\mathrm{Fe}(\mathrm{OH})_{2}$ or ferrihydrite are the most likely species present in the highly caustic aqueous tank environment. The zeta potential of an oxidized layer on the tank wall would always be positive if the oxidized layer were either $\mathrm{Fe}(\mathrm{OH})_{2}$ at $\mathrm{pH}$ values of $\geq 11.8^{41}$ or ferrihydrite at $\mathrm{pH}$ values $>8.0 .{ }^{42}$ The zeta potential (surface charge of $\mathrm{Al}(\mathrm{OH})_{3}$ would always have been negative above $\mathrm{pH}$ of 9.0. The opposite electrical charges of the $\mathrm{Al}(\mathrm{OH})_{3}$ and the ferrihydrate cause them to chemically bond. ${ }^{46}$

The SRS 2H-Evaporator deposits analyzed by Wilmarth all contained small concentrations of $\mathrm{Fe}$. The following points summarize the results of the analysis:

- $\quad$ The GDL sample contained $1.47 \mathrm{~g} / \mathrm{L} \mathrm{Fe}$ when dissolved. ${ }^{4}$

- The Evaporator wall deposits showed Fe was present in the SEM/EDAX analysis. Upon chemical dissolution, it was determined that ${ }^{2}$

- the ratio of $\mathrm{Fe} / \mathrm{Al}$ on an element wt $\%$ basis was an order of magnitude higher for the SRS $2 \mathrm{H}$-Evaporator $(0.55 / 7.92=0.07)$ wall than for the M-Area film $(0.25 / 54.3=0.005)$

- $\quad$ all of the evaporator deposits are enriched in $\mathrm{Al}(\mathrm{OH})_{3}$ over the amount needed to form the nitrated cancrinite (see Table III)

- There is about the same amount of Fe in the evaporator pot deposits as in the evaporator wall deposits $(\mathrm{Fe} / \mathrm{Al}$ element $\mathrm{wt} \%=0.48 / 5.88=0.08)$

- When the evaporator wall deposits were dissolved in nitric acid, crystalline magnetite $\left(\mathrm{Fe}_{3} \mathrm{O}_{4}\right)$ was found to have survived the acid dissolution.

- the same iron-containing phase observed in the M-Area sludge tank film. ${ }^{46}$

this iron containing oxide phase is not the commonly observed $\mathrm{Fe}(\mathrm{OH})_{3}$ found in HLW sludge

This evidence suggests that an amorphous $\mathrm{Al}(\mathrm{OH})_{3}$ component may play a role in the adherence of the aluminosilicate scale deposits. This is likely a direct function of the high surface-site densities of the silica (4.5-12 sites $\left./ \mathrm{nm}^{2}\right)$ and the $\mathrm{Al}(\mathrm{OH})_{3}\left(2\right.$ to 12 sites $\left./ \mathrm{nm}^{2}\right)$, as well as the high surface area of amorphous silica gels $\left(53,292 \mathrm{~m}^{2} / \mathrm{g}\right)$ and ferrihydrite $\left(250,306 \mathrm{~m}^{2} / \mathrm{g}\right)$ compared to crystalline $\mathrm{Al}(\mathrm{OH})_{3}$ (gibbsite; $\left.120 \mathrm{~m}^{2} / \mathrm{g}\right){ }^{42}$ 


\subsection{ACTIVITY DIAGRAM CALCULATIONAL APPROACH}

\subsection{Thermodynamic Equilibria}

The equilibria among minerals and aqueous species can be described in terms of any combination of variables that can be used to interconnect them in a balanced chemical reaction. This can include activities of dissolved molecular species or ions in aqueous solution. ${ }^{7}$ In order to represent the stability of silicate or other mineral species in natural complex environments, stability or activity diagrams are often employed. For silicate minerals the stability is usually dependent on the activity of silica, the activity of other components in the solution, and the activity of the $\mathrm{H}^{+}$ion $(\mathrm{pH})$ in the solution. While $\mathrm{a}_{\mathrm{OH}^{-}}$could be used in place of $\mathrm{a}_{\mathrm{H}^{+}}$, the $\mathrm{pH}$ is a more convenient variable. ${ }^{47}$ The equilibria on activity diagrams are conventionally expressed as $\mathrm{a}_{\mathrm{H}^{+}}\left(\mathrm{a}_{\mathrm{OH}^{-}}\right.$is converted to $a_{\mathrm{H}^{+}}$through the use of the equilibrium constant for water). ${ }^{47}$ Therefore, most activity diagrams are represented by ratios of log activity of a cation divided by the $\log \mathrm{a}_{\mathrm{H}^{+}}$, e.g., $\log \left(\right.$ activity $\mathrm{Na}^{+}$/ activity $\mathrm{H}^{+}$), on the ordinate versus $\log$ activity of $\mathrm{SiO}_{2}$ (aq) on the abscissa, where $\mathrm{SiO}_{2}$ (aq) denotes aqueous $\mathrm{SiO}_{2} \equiv \mathrm{H}_{4} \mathrm{SiO}_{4}$.

First a reversible reaction is written among the thermodynamic components of the solution and solid phases of interest and their dissociated counterparts. For example, the equilibrium between $\mathrm{NaAlSi}_{2} \mathrm{O}_{6} \cdot \mathrm{H}_{2} \mathrm{O}$ (analcime) and $\mathrm{Al}(\mathrm{OH})_{3}$ (gibbsite) can be expressed by the reaction:

$$
\underset{\text { analcime }}{\mathrm{NaAlSi}_{2} \mathrm{O}_{6} \bullet \mathrm{H}_{2} \mathrm{O}(\mathrm{s})}+4 \mathrm{H}_{2} \mathrm{O}+\mathrm{H}^{+} \rightarrow \mathrm{Na}^{+}+2 \mathrm{H}_{4} \mathrm{SiO}_{4}+\mathrm{Al}(\mathrm{OH})_{3}(s)
$$

The equilibrium constant of reaction [2] can be written as

$$
\mathrm{K}_{(2)}=\frac{\left[\mathrm{a}_{\mathrm{H}_{4} \mathrm{SiO}_{4}}\right]^{2}\left[\mathrm{a}_{\mathrm{Na}^{+}}\right]}{\left[\mathrm{a}_{\mathrm{H}^{+}}\right]}
$$

where $\mathrm{K}_{(2)}$ is the equilibrium constant of reaction [2], $\mathrm{a}_{\mathrm{i}}$ is the activity of dissolved species $\mathrm{i}, \mathrm{a}_{\mathrm{H}_{2} \mathrm{O}}=1$, and $\mathrm{a}_{\text {solid }}=1$ (for gibbsite and analcime). The equilibrium can be rewritten as:

$$
\log \left(\mathrm{a}_{\mathrm{Na}^{+}} / \mathrm{a}_{\mathrm{H}^{+}}\right)=\left(\log \mathrm{K}_{(2)}-2 \log \mathrm{a}_{\mathrm{H}_{4} \mathrm{SiO}_{4}}\right)
$$

By substituting a measured or a calculated ${ }^{\ddagger}$ value of $\mathrm{K}_{(2)}$ into Equation [4] and plotting this equation on an activity diagram with the axes $\log \left(\mathrm{a}_{\mathrm{Na}^{+}} / \mathrm{a}_{\mathrm{H}^{+}}\right)$vs. $\log _{\mathrm{H}_{4} \mathrm{SiO}_{4}}, \mathrm{a}$ 


\section{WSRC-TR-2000-00293, Rev. 1}

boundary line can be drawn representing the equilibrium boundary between analcime and gibbsite (see Figure 3a) .

The relationship between other alkali silicates phases and the aqueous solution can be described in terms of the same axes, $\log \left(\mathrm{a}_{\mathrm{Na}^{+}} / \mathrm{a}_{\mathrm{H}^{+}}\right)$vs. $\log _{\mathrm{H}_{4} \mathrm{SiO}_{4}}$, and overlain on Figure 3a. For example, one can add the stability boundary between $\mathrm{NaAlSiO}_{4}$ (nepheline) and analcime onto Figure 3a:

$$
\underset{\text { analcime }}{\mathrm{NaAlSi}_{2} \mathrm{O}_{6}} \bullet \mathrm{H}_{2} \mathrm{O}+\mathrm{H}_{2} \mathrm{O} \rightarrow \underset{\text { nepheline }}{\mathrm{NaAlSiO}_{4}}+\mathrm{H}_{4} \mathrm{SiO}_{4}
$$

where $\mathrm{K}_{(5)}$ is the equilibrium constant of reaction [5]. This can be rewritten as:

$$
\log \mathrm{K}_{(5)}=\log \mathrm{a}_{\mathrm{H}_{4} \mathrm{SiO}_{4}}
$$

which plots as a vertical line parallel to the $\log \left(\mathrm{a}_{\mathrm{Na}^{+}} / \mathrm{a}_{\mathrm{H}^{+}}\right)$axis since it is dependent only on $\log _{\mathrm{H}_{4} \mathrm{SiO}_{4}}$,i.e., a solution will be in equilibrium with either nepheline or analcime solely based on silicic acid activity. Figure $3 b$ represents the activity diagram in the Na-Al-Si$\mathrm{O}-\mathrm{H}$ system with the addition of the analcime-nepheline stability boundary.

Analcime is not stable in the silica undersaturated region of the nepheline-analcime boundary (to the left of this boundary), so the boundary between nepheline and gibbsite must also be calculated:

$$
\underset{\text { nepheline }}{\mathrm{NaAlSiO}_{4}}+3 \mathrm{H}_{2} \mathrm{O}+\mathrm{H}^{+} \rightarrow \mathrm{Na}^{+}+\mathrm{H}_{4} \mathrm{SiO}_{4}+\underset{\text { gibbsite }}{\mathrm{Al}(\mathrm{OH})_{3}}
$$

for which the equilibrium constant is:

$$
\mathrm{K}_{(7)}=\frac{\left[\mathrm{a}_{\mathrm{H}_{4} \mathrm{SiO}_{4}}\right]\left[\mathrm{a}_{\mathrm{Na}^{+}}\right]}{\left[\mathrm{a}_{\mathrm{H}^{+}}\right]}
$$

which can be rewritten as:

$$
\log \left(\mathrm{a}_{\mathrm{Na}^{+}} / \mathrm{a}_{\mathrm{H}^{+}}\right)=\left(\log \mathrm{K}_{(7)}-\log \mathrm{a}_{\mathrm{H}_{4} \mathrm{SiO}_{4}}\right)
$$

Figure $3 \mathrm{c}$ represents the activity diagram in the $\mathrm{Na}-\mathrm{Al}-\mathrm{Si}-\mathrm{O}-\mathrm{H}$ system with the additional equilibrium boundaries between nepheline and gibbsite superimposed. The additional equilibrium boundaries between the mineral phases gibbsite-paragonite, analcimeparagonite, paragonite-Na-beidellite, $\mathrm{Na}$-beidellite-gibbsite, and Na-beidellite-analcime for the Na-Al-Si-O-H system are overlain on Figure $3 \mathrm{~d}$.

The activities are related to the concentrations by the relationship given in Equation 10. 


\section{WSRC-TR-2000-00293, Rev. 1}

$$
\mathrm{a}_{\mathrm{i}}=\gamma_{\mathrm{i}} \mathrm{m}_{\mathrm{i}}
$$

where $a_{i}$ is the activity of the $i^{\text {th }}$ component, $m_{i}$ is the concentration of the $i^{\text {th }}$ component, and $\gamma_{i}$ is the activity coefficient of the $i^{\text {th }}$ component. Since the phase boundaries defined by Equations [4], [6], and [9] are dependent on the concentrations of all the species in each reaction, the positions of these boundaries change as the solution concentrations and ionic strengths of the solutions being modeled vary. 


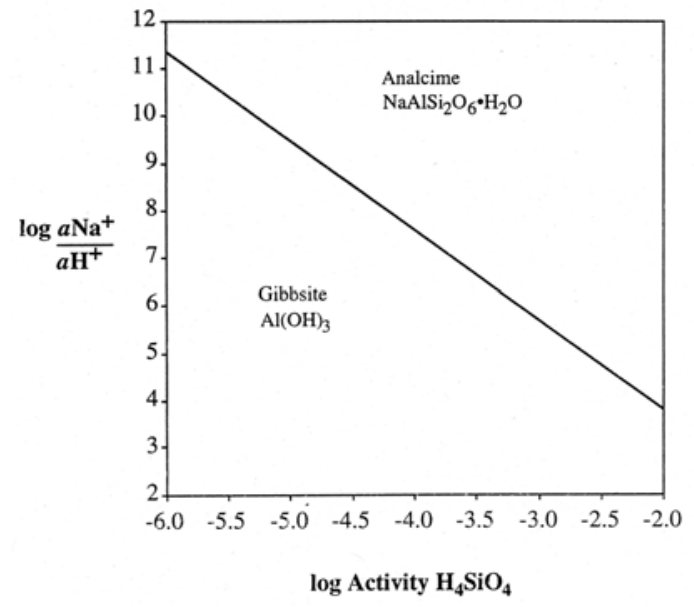

a. Stability boundary between analcime and gibbsite.

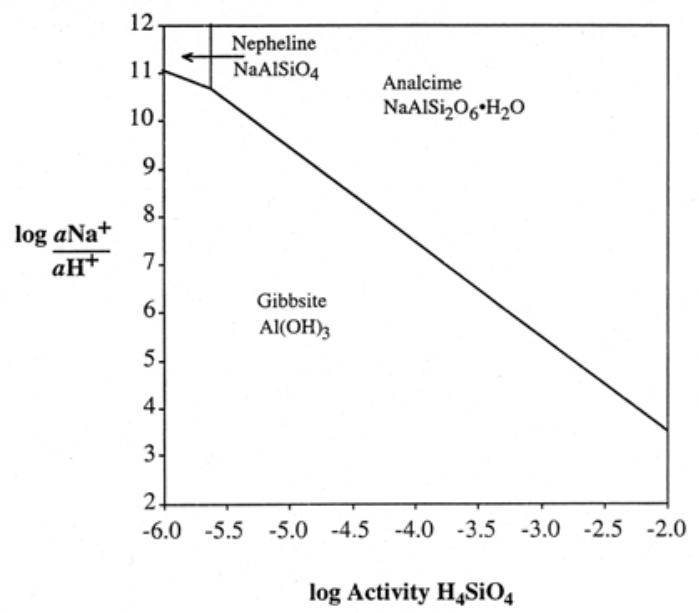

c. Stability boundary between nepheline and gibbsite.

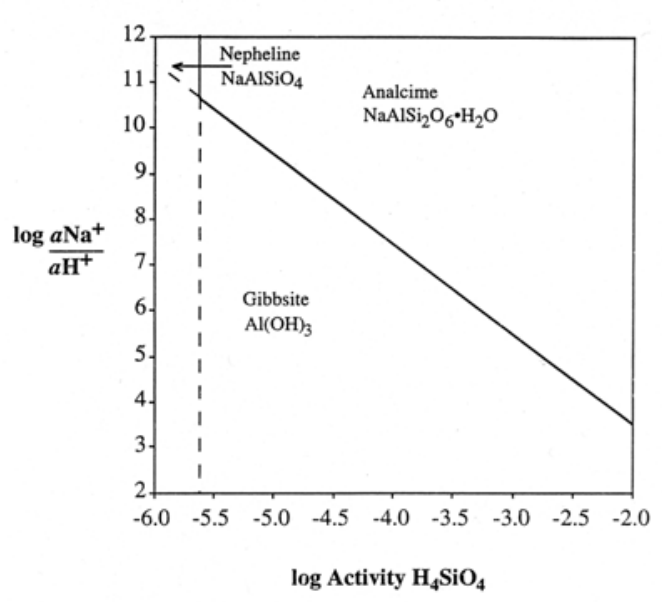

b. Stability boundary between analcime and nepheline.

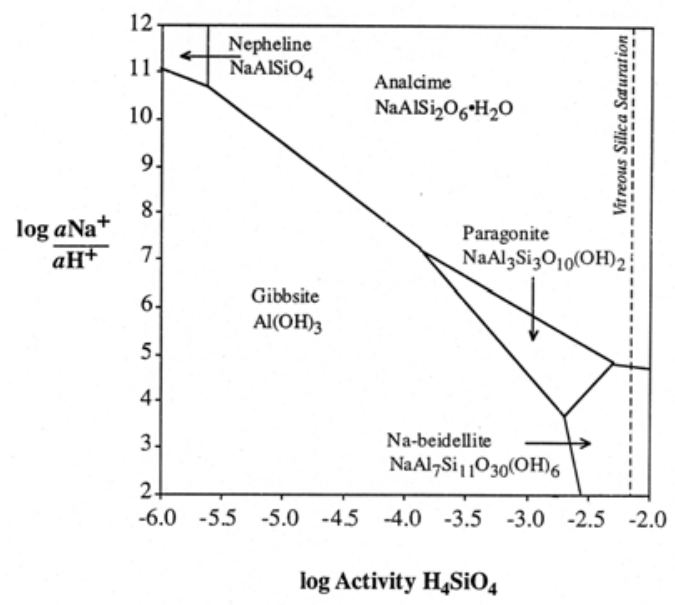

d. Multiple stability boundaries for nepheline, analcime, gibbsite, paragonite and Na-bediellite

Figure 3. Stepwise generation of an activity diagram for the Na-Al-Si-O-H system. 


\section{WSRC-TR-2000-00293, Rev. 1}

In order to relate the activities to the molal concentrations $\left(\mathrm{m}_{\mathrm{i}}\right)$ of species in the evaporator, the evaporator feed tank, and/or the evaporator drop tank, one must be able to calculate the activity coefficient $\left(\gamma_{i}\right)$ through the relationship shown in Equation 10. For dilute solutions, the Debye-Huckel equation is used to estimate activity coefficients $\left(\gamma_{i}\right)$. $^{7}$ 42 The Debye-Huckel equation assumes that ion interactions are purely Coulombic, that ion size does not vary with ionic strength, and that ions of the same sign do not interact. ${ }^{42}$ For high ionic strength solutions ( $\mathrm{I}=2$ to $6 \mathrm{~mol} / \mathrm{kg}$ ) the high density of ions in solution can lead to binary interactions between species of like charge and ternary interactions between three or more ions, some of which will be of like sign. In such systems some ions must be touching, and dilute solution concepts do not apply.

The Geochemist's Workbench has three subroutines which estimate the activity coefficients in different manners. The most accurate model for high ionic strength solutions up to $6 \mathrm{~mol} / \mathrm{kg}$ is the Pitzer model. The Pitzer model takes into account the short-range electrostatic interactions in concentrated solutions ${ }^{42}$ and a term for triple ion interactions (virial coefficients). The Geochemist's Workbench (GWB) has a subroutine containing virial coefficients for hydroxides, sulfates, carbonates, bromides, chlorides, and borates of $\mathrm{Ca}, \mathrm{Fe}, \mathrm{K}, \mathrm{Li}, \mathrm{Mn}, \mathrm{Mg}, \mathrm{Na}$, and $\mathrm{Sr}$ developed over the temperature range $0^{\circ} \mathrm{C}$ to $300^{\circ} \mathrm{C}$. This subroutine does not contain virial coefficients for aluminosilicates or uranates. Virial coefficients developed by the Pitzer methodology for the aluminosilicates and uranates can be added to GWB when these become available.

Geochemist's Workbench (GWB) also contains a subroutine for calculating activity coefficients from virial coefficients developed using the Harvie-Møller-Weare (H-M-W) methodology $\mathrm{y}^{48}$ for sulfates, chlorides, carbonates and hydroxides of $\mathrm{Ca}, \mathrm{K}, \mathrm{Mg}$, and $\mathrm{Na}$. This subroutine contains coefficients derived for only one temperature, $25^{\circ} \mathrm{C}$. This subroutine does not contain virial coefficients for aluminosilicates or uranates.

The B-dot $\left(\mathrm{B}^{*}\right)$ method of Helgeson, ${ }^{49}$ embedded in The Geochemist's Workbench (GWB) software, can be used as a general method to calculate activity coefficients and activities in a consistent manner for all species including uranates and aluminosilicates. The $\mathrm{B}^{\bullet}$ function, as modified by Helgeson, ${ }^{49}$ includes a parameter for the distance of closest approach of the ions in solution as defined by Pitzer and Brewer. ${ }^{50}$ A discussion of the Helgeson ${ }^{49}$ methodology to other methods used for high ionic strength solutions is given in Appendix A.

In order to minimize the dependence of the modeling on the activity coefficient estimation, the solubility and/or extrapolated solubility of the $\mathrm{NAS}_{\text {gel }}$, the mixed zeolite, Zeolite-A, hydroxysodalite, gibbsite, and $\mathrm{NaAlO}_{2}$ at 8.5 molal $\mathrm{Na}$ were used as input to GWB. The nature of the extrapolation from lower Na molality to 8.5 molality is discussed in Appendix B. 


\section{WSRC-TR-2000-00293, Rev. 1}

\subsection{Kinetic Considerations}

Evaluation of complex mineral equilibria makes it possible to construct activity diagrams for the wide range of solution conditions that exist in the SRS evaporators and waste tanks. Overlaying solution compositions on a diagram such as Figure $3 \mathrm{~d}$ allows one to determine if a waste solution is in the stability field of a given mineral phase, which may cause that mineral to precipitate if the kinetics are favorable.

For mixed zeolite species composed of nitrated cancrinite $\left(\mathrm{Na}_{8} \mathrm{Al}_{6} \mathrm{Si}_{6} \mathrm{O}_{24}\left(\mathrm{NO}_{3}\right)_{2}\right) \bullet 4 \mathrm{H}_{2} \mathrm{O}$, forming from a Zeolite-A precursor, Wilmarth ${ }^{51}$ has shown that the kinetics are on the order of 3-5 hours at $110^{\circ} \mathrm{C}$ (the approximate temperature of the SRS 2H-Evaporator.

Jantzen ${ }^{10}$ has shown that Zeolite $\mathrm{A}\left(\mathrm{Na}_{12}\left[\mathrm{Al}_{12} \mathrm{Si}_{12} \mathrm{O}_{48}\right] \bullet 27 \mathrm{H}_{2} \mathrm{O}\right)$ can form in $\sim 29$ hours at ambient temperatures while the Linde zeolite process calls for formation in 2-3 hours at temperatures of $85-110^{\circ} \mathrm{C} .{ }^{19}$ Gasteiger et al. ${ }^{17}$ found that basic sodalite $\left(\mathrm{Na}_{8}\left[\mathrm{Al}_{6} \mathrm{Si}_{6} \mathrm{O}_{24}\right](\mathrm{OH})_{2} \bullet 1.5 \mathrm{H}_{2} \mathrm{O}\right)$ and sodalite $\left(\mathrm{Na}_{8}\left[\mathrm{Al}_{6} \mathrm{Si}_{6} \mathrm{O}_{24}\right](\mathrm{Cl})_{2}\right)$ formation was $>99 \%$ complete in 24 hours at $95^{\circ} \mathrm{C}$. Mattus, et. al. ${ }^{52}$ demonstrated that crystallization of zeolite phases from the solution/gel occurred within 14 minutes at the evaporator operating temperature of $130^{\circ} \mathrm{C}$.

Likewise, finely dispersed sodium diuranate phases were found to form readily at $25^{\circ} \mathrm{C}$ in about 10-60 minutes, ${ }^{32}$ reaching equilibrium in about 5 days. ${ }^{53}$ Since the reactions that form the sodalite and sodium diuranate deposits in the SRS 2H-Evaporator are relatively fast kinetically, the equilibrium activity diagrams (normally applicable on geologic time scales) are useful models for understanding and modeling the mineral scale deposits forming under evaporator conditions.

In order to model the precipitation of aluminosilicates in the SRS 2H-Evaporator, an assumption was made to model only the phases that could form kinetically in the short evaporator residence time, e.g. 5-9 hours. Since the aluminosilicates form via the aging sequence (a chain of reactions as shown in Figure 2), a steady-state approximation was made and the steady-state "equilibrium" of the kinetically most rapid forming aluminosilicate phase, the $\mathrm{NAS}_{\mathrm{gel}}$, was modeled. The steady-state approximation assumes that during most of the reaction critical to the deposition of the NAS $\mathrm{Sel}_{\text {gel }}$ that the concentration of this intermediate may be considered essentially constant. This approximation is particularly good when the intermediates are very reactive. ${ }^{54}$ This approximation allows equilibrium thermodynamics to be applied to a phase such as the $\mathrm{NAS}_{\text {gel }}$ even though it eventually ages to another more stable phase with time in the tanks. 


\subsection{OPERATIONAL HISTORY OF THE SRS 2H-Evaporator}

The SRS 2H-Evaporator feed tank is Tank $43 \mathrm{H}$ and the drop tank is Tank $38 \mathrm{H}$. A summary of the significant events during the January 1996 to October 1999 operation of the SRS 2H-Evaporator is given in Table III. The receipt of high Si containing wastes (in $\mathrm{kgs}$ ) from DWPF* and the receipt of high $\mathrm{Al}$ containing wastes (in $\mathrm{kgs}$ ) from $\mathrm{H}$-Canyon ${ }^{55}$ is shown in Figure 4. The periods of normal operation are indicated by solid arrows while dashed ones indicate the periods of difficult operation, including line pluggages and scaling of aluminosilicate deposits.

The current SRS 2H-Evaporator pot was installed prior to DWPF startup. The SRS 2HEvaporator began receiving DWPF recycle from non-radioactive Qualification runs on January 31, 1996. These DWPF wastes had been accumulating in the SRS 2HEvaporator feed tank (Tank 43H) since December 22, 1995. In February and March 1996, the SRS 2H-Evaporator feed tank received HEME/HEPA digest residues from a non-radioactive full scale digestion demonstration performed at DWPF. These residues were an aluminosilicate gel that contained zeolite seed crystals as noted during laboratory bench scale studies. ${ }^{56}$

In March 1996 the SRS 2H-Evaporator began to be fed some of the first radioactive wastes from DWPF processing (Table III) which consisted of some glass making frit as carryover from the melter off-gas system. In December 1996 the SRS 2H-Evaporator feed tank received several large carryovers of $70 \mathrm{wt} \%$ frit and $30 \mathrm{wt} \%$ waste from the Slurry Mix Evaporator (SME), a process tank preceding the DWPF melter. Subsequently, several moderate SME carryovers were received during February and March 1997 (Table III and Figure 4). After two months of large to moderate SME carryovers, the first evidence of scaling was observed in the SRS 2H-Evaporator system (April 25, 1997; see Table III). During the time period when copious amounts of DWPF frit rich in silicon were being fed to the SRS 2H-Evaporator feed tank from the SME carryovers, the feed pump was at a height of 65 " from the bottom of the tank, only $~ 12$ " above the top of the sludge layer at 53" (Figure 5).

On June 16, 1997 a new feed pump was installed at a height of 100" from the bottom of the tank or $~ 50$ " above the sludge layer. About 2 months after the new feed pump was installed which corresponded to 4 months after the first evidence of scaling was observed, the gravity drain line (GDL) plugged. Inspection of the evaporator demonstrated that there were deposits on the internal sections of the evaporator as well. Nitrated sodalite/cancrinite deposits were identified as the cause. The GDL was cleaned by water flushing in the direction of the drop tank (Tank 38H). Some deposits were still visible in on the walls of the line during the inspection.

The SRS 2H-Evaporator ran well for about a year, from August 1997 until the GDL plugged again in June 1998 (Figure 4). During this time period there was one small SME carryover in September 1997 (Figure 4) that was sent to Tank 22 and not to the SRS 2H-

\footnotetext{
‡ Spreadsheet supplied by Jeff Gillam
} 


\section{WSRC-TR-2000-00293, Rev. 1}

Evaporator feed tank and one SME carryover in November 1997 that contained only sludge and no frit. Neither of these SME carryovers would have impacted the SRS $2 \mathrm{H}$ Evaporator. The November 1997 SME carryover was the last SME carryover experienced by the DWPF (Figure 4).

Inspections of the SRS 2H-Evaporator lift jumpers during the year of acceptable operation (August 1997-June 1998) did not show any deposits in January 1997 or March 1998. In April $1998 \mathrm{H}$-Canyon started sending moderate amounts of $\mathrm{Al}$ (shown in kgs in Figure 4) to the SRS 2H-Evaporator. Within 2 months of the initiation of these higher concentrations of Al waste, the GDL plugged again.

The GDL was cleaned again in June 1998, this time by pressure washing in the direction of the drop tank and back into the evaporator pot. An inspection of the evaporator pot 4 days after the pressure washing indicated that the liquid in the evaporator pot was very turbid, even the lift line could not be observed.

The moderate Al containing wastes from H-Canyon continued from April 4, 1998 to about December 4, 1998. Inspection of the evaporator pot during that time (June and September 1998) indicated that deposits had formed on the warming coils and vessel walls but that the deposits were not excessive. In late December 1998, the SRS 2HEvaporator began receiving copious amounts of $\mathrm{Al}$ (shown in $\mathrm{kgs}$ in Figure 4) from $\mathrm{H}$ Canyon. Inspection of the pot in January 1998 (one month after these high Al transfers from H-Canyon were received) showed a significant buildup of scale material that appeared to coat all the internal equipment in the evaporator. Erratic operation continued with as many as 90 flushes of the GDL, demister, lift line and pot per month until the SRS 2H-Evaporator shut down in October 1999 (Table III).

The SRS 2H-Evaporator feed tank (Tank $43 \mathrm{H})$ received multiple recycles of supernate from the drop tank (Tank $38 \mathrm{H})$ on about a monthly basis and occasional transfers from Tanks 22 and 42. Tank $43 \mathrm{H}$ has about 53" of sludge at the bottom (Figure 5). The transfer pump to the evaporator is currently located at a height of 100" from the bottom of the tank. The level of the supernate varies depending on the volume of a given transfer into the tank.

Tank $38 \mathrm{H}$, the drop tank has no significant sludge accumulation at the bottom. It has a transfer jet that is located 248" above the bottom of the tank (Figure 5) and a salt layer at 261" above the bottom of the tank.

The $2 \mathrm{H}$-Evaporator had routinely been operated at $\sim 120^{\circ} \mathrm{C}$ from 1996 to 1999 . Tanks $43 \mathrm{H}$ and $38 \mathrm{H}$ have been at a nominal temperature of $\sim 40^{\circ} \mathrm{C}$. 
WSRC-TR-2000-00293, Rev. 1

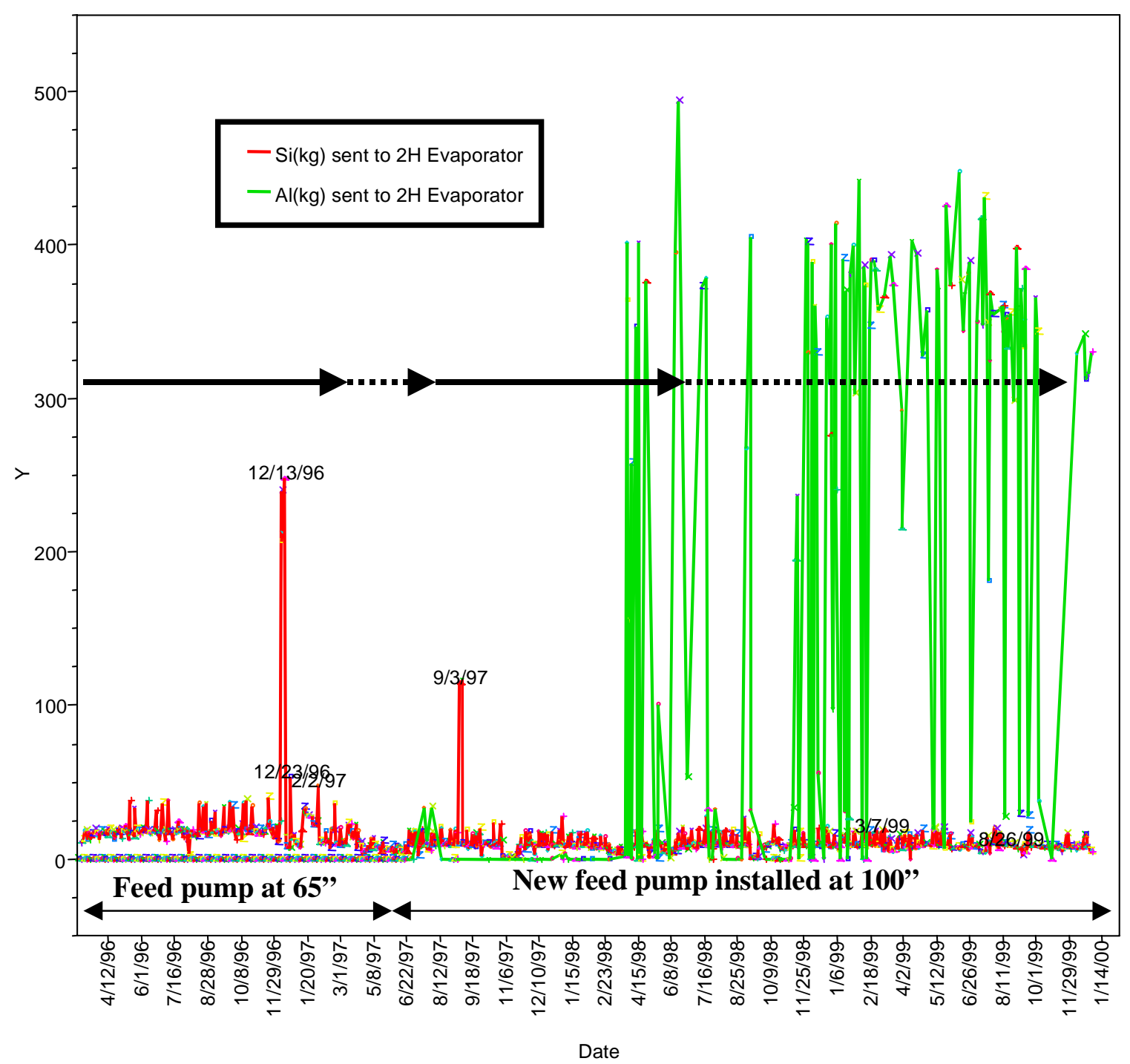

Figure 4. Time line of Si transfers in kgs from DWPF and Al transfers in kgs from HCanyon for the SRS 2H-Evaporator. Superimposed are solid arrows indicating time periods when the evaporator was operating without scale being observed and without plugging. The dashed arrows indicate operating times when scale was observed and/or plugging was occurring. 
WSRC-TR-2000-00293, Rev. 1

Table III. Significant Events During the SRS 2H-Evaporator Operation

\begin{tabular}{|c|c|c|}
\hline Date & Event & Deposition \\
\hline $1 / 31 / 96$ & $\begin{array}{l}\text { New evaporator pot first receives feed (DWPF recycle } \\
\text { from non radioactive Qualification runs that had been } \\
\text { accumulating in T43 since } 12 / 22 / 95 \text { ). Feed pump at } \\
65 \text { "above bottom of T43 near sludge surface }\end{array}$ & \\
\hline $\begin{array}{l}2 / 25 / 96 \\
\text { and } 3 / 18 / 96\end{array}$ & $\begin{array}{l}\text { HEME/HEPA digest solutions fed to evaporator which } \\
\text { included a gel phase containing zeolite seeds }\end{array}$ & \\
\hline $3 / 07 / 96$ & $1^{\text {st }}$ radioactive transfers to T43 from DWPF & \\
\hline $5 / 09 / 96$ & $\begin{array}{l}\text { T43 "top layer" samples contain whitish solids that are } \\
\text { aluminosilicates }\end{array}$ & \\
\hline $\begin{array}{l}12 / 9 / 96 \text { and } \\
12 / 23 / 96\end{array}$ & $\begin{array}{l}\text { Large Slurry Mix Evaporator (SME) carryovers from } \\
\text { DWPF containing glass frit }\end{array}$ & \\
\hline $\begin{array}{l}2 / 20 / 97 \text { to } \\
3 / 20 / 97\end{array}$ & $\begin{array}{l}\text { Several moderate (SME) carryovers from DWPF } \\
\text { containing glass frit }\end{array}$ & \\
\hline $4 / 25 / 97$ & & $\begin{array}{l}\text { First evidence of } \\
\text { scaling }\end{array}$ \\
\hline $6 / 16 / 97$ & New feed pump installed at 100" from T43 floor & \\
\hline $8 / 23 / 97$ & $\begin{array}{l}\text { GDL cleaned and flushed in direction of drop tank (T38); } \\
\text { some deposits still on walls noted in 8/27/97 inspection }\end{array}$ & $\begin{array}{l}\text { Lots of Deposits in } \\
\text { Evaporator; GDL } \\
\text { plugged }\end{array}$ \\
\hline 9/3/97 & Small SME carryover containing glass frit & \\
\hline $11 / 26 / 97$ & Small SME carryover - does not contain glass frit & \\
\hline $126 / 97$ & Inspection of lift jumper (10’) & $\begin{array}{l}\text { No significant } \\
\text { deposits }\end{array}$ \\
\hline $3 / 19 / 98$ & Inspection of lift jumper shows & $\begin{array}{l}\text { No significant } \\
\text { deposits }\end{array}$ \\
\hline $\begin{array}{l}4 / 4 / 98- \\
12 / 4 / 98\end{array}$ & Moderate $\mathrm{Al}$ receipt from $\mathrm{H}$-Canyon & \\
\hline $6 / 15 / 98$ & $\begin{array}{l}\text { GDL cleaned and pressure washed in direction of drop } \\
\text { tank (T38) and back into evaporator pot }\end{array}$ & GDL plugged \\
\hline $6 / 19 / 98$ & $\begin{array}{l}\text { Pot inspection demonstrates that liquid in evaporator is } \\
\text { very turbid - lift line not visible }\end{array}$ & \\
\hline $\begin{array}{l}6 / 26 / 98 \\
\text { and } \\
9 / 9 / 98\end{array}$ & Inspection of pot & $\begin{array}{l}\text { Deposits on } \\
\text { warming coils and } \\
\text { vessel walls but not } \\
\text { excessive }\end{array}$ \\
\hline $12 / 98-10 / 99$ & Large $\mathrm{Al}$ receipt from $\mathrm{H}$-Canyon & \\
\hline $1 / 18 / 99$ & Inspection of pot & $\begin{array}{l}\text { Significant buildup } \\
\text { of scale material on } \\
\text { all internal equip- } \\
\text { ment in evaporator }\end{array}$ \\
\hline $7 / 99-10 / 99$ & 90 flushes of GDL, demisters, lift line and pot in a month & \\
\hline $10 / 99$ & Evaporator shut down & \\
\hline
\end{tabular}




\subsection{ANALYTIC DATA AVAILABLE FOR SRS 2H-Evaporator MODELING}

\subsection{Availability of Analytic Data}

A compilation of molar chemical analyses for Tanks 43 and 38 appears in Table IV and Table V. There were sparse and incomplete data in the tank farm historic records. Specifically there were no Si analyses available for the feed tank (Tank 43H) and drop tank compositions between November 1992 and May 1997. Data for several cations were missing from the tank farm historic records, most notably $\mathrm{Fe}$ and $\mathrm{Si}$. The Fe analyses were added into Table IV using data from Wilmarth. ${ }^{57}$ The Si numbers estimated are discussed below when the data from several composite samples representative of dip samples taken from January 1995 to December 1996 are discussed. Conversely, Wilmarth ${ }^{57}$ did not analyze for the cation $\mathrm{K}^{+}$nor several anions, e.g. $\mathrm{Cl}, \mathrm{CO}_{3}^{2-}, \mathrm{F}^{-}, \mathrm{NO}_{2}^{-}$, $\mathrm{NO}_{3}^{-}, \mathrm{OH}^{-}, \mathrm{PO}_{4}^{3-}, \mathrm{SO}_{4}^{2}$. The anion and $\mathrm{K}$ analyses shown in yellow in Table IV and Table $\mathrm{V}$ were averaged from the data provided in the tank farm records.

In addition, several composite samples had been analyzed by Wilmarth et. al. ${ }^{4}$ for Tanks 43 and Tank $38 \mathrm{H}$. These composite samples included material collected for the period from January 1995 through December 1996. These sample analyses were used to fill in missing data in Table IV and Table V for this time period (see yellow shading). While the composite dip samples indicate that the Si concentrations should be in the $1.78 \mathrm{E}-03 \mathrm{M}$ range, it is more likely that the $\mathrm{Si}$ values sent to the SRS $2 \mathrm{H}$-Evaporator were much higher since the feed pump was at a height of 65 " in the tank during this time period, e.g. the feed pump would have seen elevated $\mathrm{Si}$ levels as discussed in Section 4.4.1. The Si numbers for February 1996 to May 1997 were, therefore, estimated from the Wilmarth ${ }^{57}$ analysis taken at 64" in Tank $43 \mathrm{H}$ on January $2000^{\ddagger}$ since the SRS $2 \mathrm{H}$-Evaporator feed pump was at a height of 65 " from the initiation of feed from Tank $43 \mathrm{H}$ to the new evaporator pot in January 1996 until a new feed pump was installed at 100" from the tank bottom on June 16, 1997. Basing the Si estimations on the January 2000 sample analysis is probably conservative since this sample had been taken after Tank $43 \mathrm{H}$ had settled and clarified for 6 weeks. The value probably represents the minimum concentration of Si that entered the SRS 2H-Evaporator while the feed pump was at a height of 65 ”.

\subsection{Consistency of Analytic Data}

In order to use the chemical analyses compiled in Table IV and Table V for modeling, the data had to be made internally consistent, e.g., anion and cation charges had to be balanced. In balancing charges, it was assumed that the $\mathrm{Na}^{+}$molarities were more accurate than the anion molarities. If the sum of the anion charges differed significantly from the sum of the cation charges, molarities of the three principal anions, $\mathrm{OH}^{-}, \mathrm{NO}_{3}$, and $\mathrm{NO}_{2}^{-}$, were adjusted so that these sums became equal. The measured molarities for all three principal anions were multiplied by the same factor to achieve charge neutrality.

\footnotetext{
‡ after the evaporator had been shut down
} 


\section{WSRC-TR-2000-00293, Rev. 1}

Data for which anion charges were adjusted are shaded green in Table IV and Table V. The charge balance calculations assumed that each ionic species was present in its most prevalent valence state; most importantly, $\mathrm{Al}$ was modeled as $\mathrm{Al}(\mathrm{OH})_{4}{ }^{-}$.

In order to account for the effect of temperature on solution densities so that the data in Table IV and Table V could be evaluated at different temperatures, molar concentrations were converted to molalities (Table VI and Table VII). The molalities are based on calculated solution densities (Equation 11a). ${ }^{7}$ The solution densities were calculated from a calculated $\mathrm{Na}^{+}$molarity, $\left[\mathrm{Na}^{+}\right]_{\text {calc }}$, using Equation $11 \mathrm{~b}$ derived by Walker and Coleman $^{58}$ for H-Canyon waste solutions at $25^{\circ} \mathrm{C}$.

$$
m=M\left(\frac{\text { weight solution }}{(\text { weight solution }- \text { total weight solutes })}\right)\left(\frac{1}{\text { density }_{\text {calc }}}\right)
$$

where $\mathrm{m}=$ molality

$$
\mathrm{M}=\text { molarity }
$$

$$
\begin{aligned}
& \text { weight solutes }=\frac{\text { dissolved solids }(\mathrm{g} / \mathrm{L})}{1000 \mathrm{~L}} \\
& \qquad \begin{array}{c}
\mathrm{Al}(\mathrm{OH})_{4}^{-}+\mathrm{Cl}^{-}+\mathrm{CO}_{3}^{-2}+\mathrm{C}_{2} \mathrm{O}_{4}^{-2}+\mathrm{F}^{-}+\mathrm{NO}_{2}^{-}+\mathrm{NO}_{3}^{-} \\
\text {dissolved solids }=+\mathrm{OH}^{-}+\mathrm{PO}_{4}^{-3}+\mathrm{SO}_{4}^{-2}+\mathrm{Fe}(\mathrm{OH})_{4}^{-}+\mathrm{K}^{+}+\mathrm{H}_{2} \mathrm{SiO}_{4}^{-2}+ \\
\mathrm{UO}_{2}(\mathrm{OH})_{\frac{7}{3}}+\left[\mathrm{Na}_{\text {calc }}^{+}\right]
\end{array} \\
& \text {density }_{\text {calc }} \equiv \rho=1.0133+0.040469\left[\left.\mathrm{Na}^{+}\right|_{\text {calc }}\right.
\end{aligned}
$$

where $\rho$ is the solution density in $\mathrm{g} / \mathrm{cm}^{3}$ and $\left[\mathrm{Na}^{+}\right]_{\text {calc }}$ is the calculated molar $\mathrm{Na}^{+}$ concentration from Equation 11c.

$$
\begin{aligned}
& \mathrm{Na}_{\text {calc }}^{+}=\mathrm{NaAl}(\mathrm{OH})_{4}+\mathrm{NaCl}+\mathrm{Na}_{2} \mathrm{CO}_{3}+\mathrm{Na}_{2} \mathrm{C}_{2} \mathrm{O}_{4}+\mathrm{NaF}+ \\
& \mathrm{NaNO}_{2}+\mathrm{NaNO}_{3}+\mathrm{NaOH}+\mathrm{Na}_{3} \mathrm{PO}_{4}+\mathrm{Na}_{2} \mathrm{SO}_{4}+\mathrm{NaFe}(\mathrm{OH})_{4}^{-} \\
& -\mathrm{KOH}+\mathrm{Na}_{2} \mathrm{H}_{2} \mathrm{SiO}_{4}+\mathrm{Na}\left(\mathrm{UO}_{2}\right)_{3}(\mathrm{OH})_{7}
\end{aligned}
$$

The molal contributions from $\mathrm{CO}_{3}$ and $\mathrm{C}_{2} \mathrm{O}_{4}$ were summed as a total $\mathrm{CO}_{3}$ contribution while the $\mathrm{NO}_{2}$ and $\mathrm{NO}_{3}$ were summed as a $\mathrm{NO}_{3 \text { since }}$ Geochemist's Workbench can only accommodate one carbon and one nitrogen species at a time. 


\section{WSRC-TR-2000-00293, Rev. 1}

\subsection{Quality of Analytic Data}

The SRTC and the F-area laboratory both analyzed samples taken in February 2000 and October 2000 from Tank 43H (see Table IV). Note that the F-area laboratory sample for February 21, 2000 was a surface dip sample and the reported Si concentration is $1.00 \mathrm{E}$ 03M (28 ppm). The SRTC laboratory analyzed a sample taken about a month earlier (January 16, 2000) and the analysis indicated 3.08E-03M ( 86 ppm). ${ }^{57}$ At this time, SRTC was not using the improved silica analysis methodology discussed below.

In October 2000, the F-area laboratory analyzed a dip sample and the $\mathrm{Si}$ analyses were reported as 3.00E-03M (84ppm; see Table IV) while SRTC measured a lower concentration in the supernate, e.g. between 1.08E-03 ( 30ppm) to $1.6 \mathrm{E}-03(\sim 45 \mathrm{ppm})$ at the feed pump height of $\sim 100$ " and 2.00E-03 ( 56ppm) at a height of 201" in the tank (see Figure 9$),{ }^{59}$ using the improved silica analysis methodology discussed below.

Based on the above data and the data presented in Part II of this study, ${ }^{3}$ it appears that the F-area laboratory Si analyses are biased high. Part of the error is due to nonrepresentative sampling and part is due to analytic detection limits. The SRTC and the Farea laboratory both dilute the original sample in order to handle the radioactive samples safely in a radioactive hood and match the $\mathrm{Na}$ concentration range to the instrument range. The F-area laboratory uses two dilutions, one $21 \mathrm{X}$ and one $10 \mathrm{X}$. If the instrument detection limit is in the $0.2 \mathrm{ppm}$ range for $\mathrm{Si}$ in the $4 \mathrm{M} \mathrm{HNO}_{3}$ solutions analyzed, $\neq$ then 210 times the detection limit $(210 \times 0.2 \mathrm{ppm})$ would give a minimum detection limit of $42 \mathrm{ppm}$ for $\mathrm{Si}$ in an undiluted sample. Since measurements made at or near the detection limit can be in error by 100-300\%, the repeated measurement of Si values at or about 80$85 \mathrm{ppm}$ in an undiluted sample indicates that the F-area laboratory is biased high by about $2 \mathrm{X}$ when the concentrations of $\mathrm{Si}$ in the undiluted sample are in the 30-55 ppm range or $>3 \mathrm{X}$ when the concentrations are $<30 \mathrm{ppm}$ ( see Part II of this study ${ }^{3}$ ).

The F-area laboratory takes a small pipette sample of a large volume of diluted aliquot that contains $\mathrm{Si}$ in solution and colloidal $\mathrm{Si}$. The $\mathrm{Si}$ in solution is homogeneously distributed and hence "representative." The colloidal Si is not homogeneously distributed in the solution. Since the Inductively Coupled Plasma Spectrometer atomizes both the Si in solution and the colloidal Si, any inhomogeneities in the diluted sample can lead to inaccurate and non-reproducible $\mathrm{Si}$ analyses providing that the total Si concentration is above the detection limit of the instrument. Because of these complexities, SRTC has developed a method by which the entire diluted sample is filtered so that the total amount of Si (both soluble and colloidal) can be more accurately determined. A liter of solution is filtered. The filtrate, representing the soluble silica, is homogeneous and can be accurately measured by ICP. The colloidal silica on the filter paper is dissolved and measured separately. The two are added together for a final total silica analysis that is representative of an entire liter of sample ${ }^{57}$ rather than a few milliliters of solution. The quality of this method is discussed in Part II where there are more available H-area tank data to make comparisons between the F-area laboratory and the SRTC methodology. Recently, Coleman ${ }^{60}$ has tested a spectro-photometric method from the 1920's that uses

¥ Mark Jones (F-Area Laboratory on April 5, 2001) 


\section{WSRC-TR-2000-00293, Rev. 1}

molybdic acid to analyze simultaneously for the monosilicic acid in solution, the polysilicic acids in solution, and colloidal silica. Coleman's analyses have verified Wilmarth's analytic results.

The majority of Si data shown in Table IV and Table V are from the F-area laboratory. This data and the interpretation of this data used to generate activity diagrams must be used with caution since the analyses have been shown to be biased high.

\subsection{Analytic Data Populations}

\subsubsection{Depth Populations}

The chemical data for Tank $43 \mathrm{H}$ given in Table IVand Figure 6 were taken at various times and at various depths within the tank. The chemistry of the sample reported to have been taken 3" above of the sludge layer in January/February 2000, at a height of 64", was distinctly different than the chemistry of the remaining supernate samples higher in the tank. ${ }^{57}$ Notably, Al, Fe, Si, U, and Mn concentrations were very elevated indicating that 61-64" was about the level of the sludge layer (Figure 6). Wilmarth and Peterson's report $^{57}$ indicates that this sample was brown and viscous and contained considerable sludge solids. It should be noted that these samples had been taken after Tank $43 \mathrm{H}$ had settled for 6 weeks.

In October 2000 samples were also taken from Tank $43 \mathrm{H}$ that were reported to be $~ 14$ " above the sludge layer. ${ }^{59}$ While the SRS $2 \mathrm{H}$-Evaporator had not been operational since October 1999, discharges of $\mathrm{H}$-canyon waste had been made to Tank $43 \mathrm{H} . \neq$ The height of the sludge layer was determined to be $\sim 52$ " by turbidity measurements made on March 6, 2001 and a turbid layer was encountered at $~ 70 "$ (Figure 6). ${ }^{59}$ The chemical data in reference 59 and Figure 6 exhibit higher than normal Al, Si, Fe, U, and $\mathrm{Mn}$ in the samples taken at 66" and 72" above the bottom of the tank indicating that the sludge layer may be higher than the 52" level determined by the turbidity probe or that the turbid region contains high concentrations of unsettled sludge components. For example the $U$ concentrations observed in or at the sludge surface in January/February 2000 after the tank had settled for 6 weeks are $\sim 5 \mathrm{X}$ higher than the $\mathrm{U}$ concentrations noted in the turbid zone during the October 4, 2000 sampling.

The depth population between the surface of the sludge (52-64") and 24" above the sludge layer is defined as the "Zone of Turbidity (ZOT)." The turbidity probe measurements taken in Tank $43 \mathrm{H}$ indicate that the ZOT is $\sim 18$ " in this tank while the analysis of the VDS samples from Tank 32 (see Part II of this study ${ }^{3}$ ) indicate a depth of 20". The chemistry of the solutions in the ZOT can be affected by the following:

- $\quad$ turbulent eddies of sludge stirred up during recycles/flushes

\footnotetext{
\$ Kent Gilbreath personal communication (May 2001) 30
} 


\section{WSRC-TR-2000-00293, Rev. 1}

- frequency of flushes and recycles

- influence from feed pump turbulence during transfers out of the tank and into the evaporator

- potential for silica rich sol accumulation layer, a layer which will not settle because silica sols are hydrophobic and silica colloids repel each other ${ }^{61}$ and remain suspended for long periods of time (see Figure 7). 


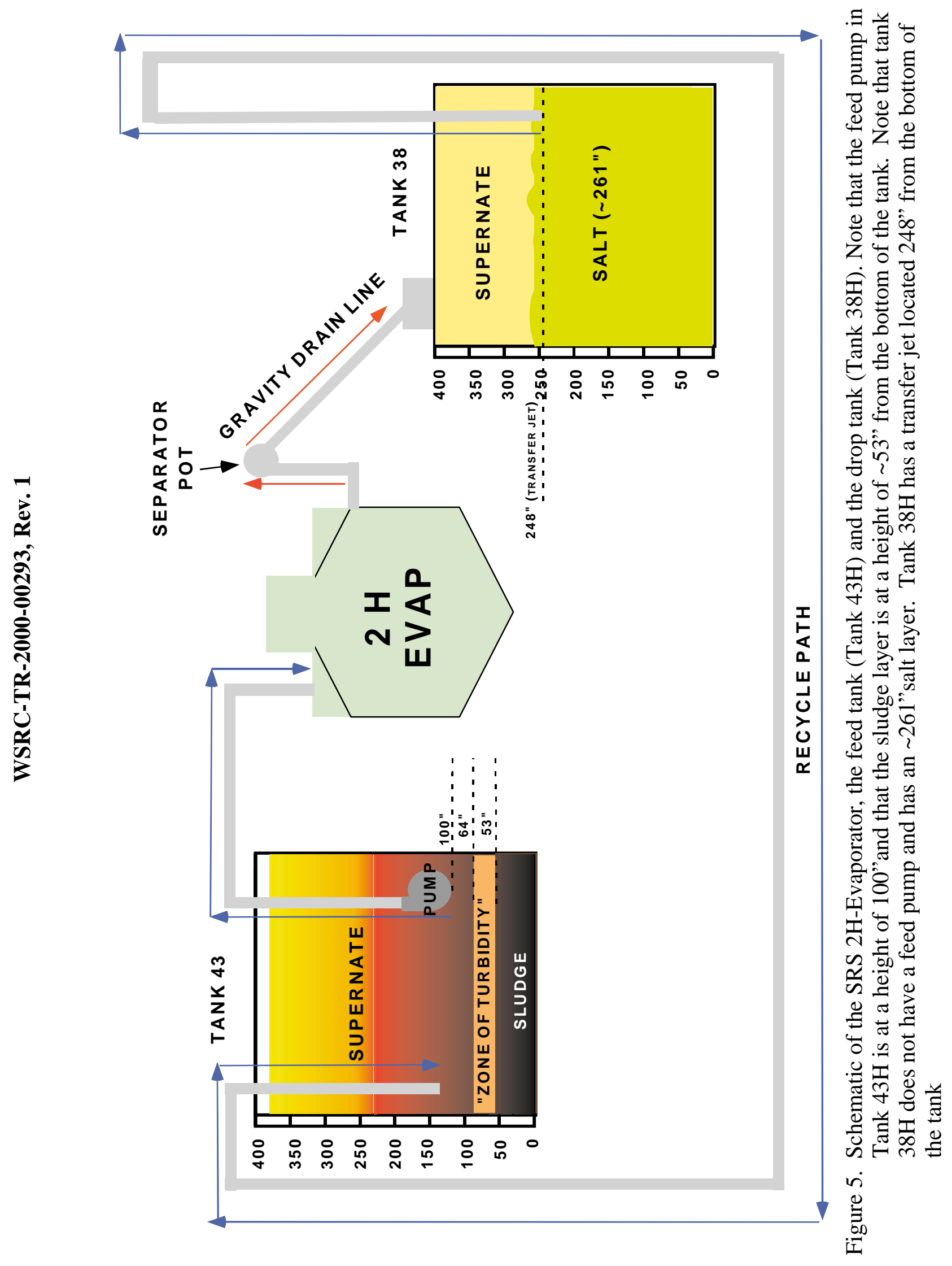


Samples Taken January 16 to February 2, 2000

(After 6 Weeks of Settling and Supernate Had Clarified)

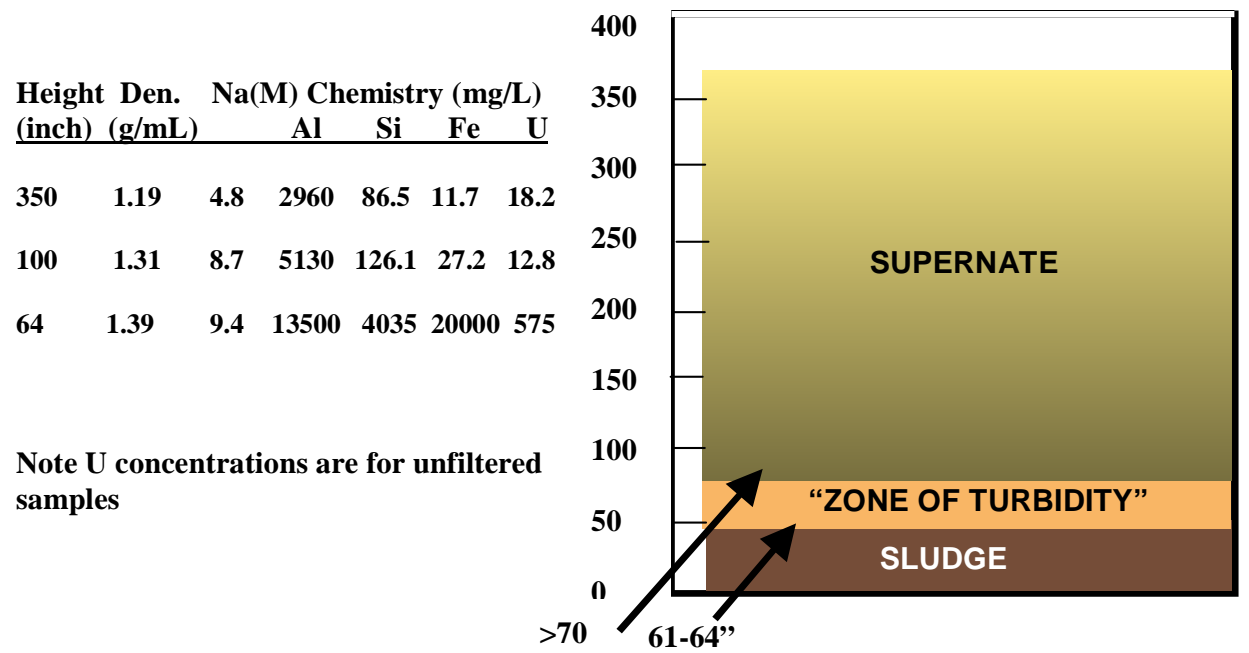

Samples Taken October 4, 2000

Turbidity Measurements Made on March 6, 2001

Height Den. Na(M) Chemistry (mg/L) (inch) $(\mathrm{g} / \mathrm{mL}) \quad \mathrm{Al} \quad \mathrm{Si} \quad \mathrm{Fe} \quad \mathrm{U}$

$\begin{array}{lllllll}201 & 1.22 & 4.3 & 0.10 & 56.1 & 9.0 & 1.6\end{array}$

$101 \quad 1.33 * 2.9 * \quad 0.06 * 37.7 * 5.2 * 2.0$

$86 \quad 1.19 * 2.7 * \quad 0.06 * 54.3 * 9.6 * 8.1$

$\begin{array}{lllllll}72 & 1.38 & 7.4 & 0.28 & 1440 & 20500 & 127\end{array}$

$\begin{array}{lllllll}66 & 1.38 & 7.7 & 0.27 & 1200 & 17600 & 144\end{array}$

* average of 2 samples

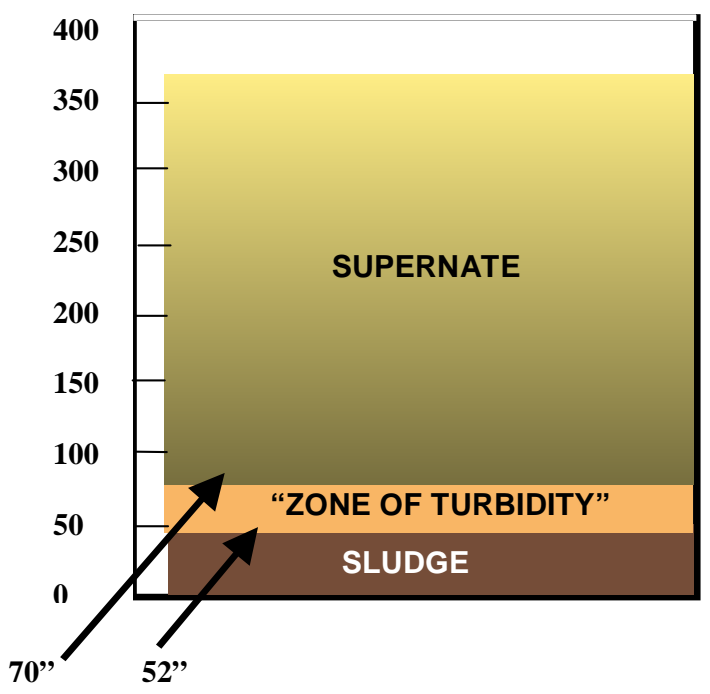

Figure 6. Depth populations delineated in the SRS 2H-Evaporator Feed Tank (Tank $43 \mathrm{H})$. Data in upper figure from Wilmarth and Peterson ${ }^{57}$. Data in lower figure from Wilmarth. 
Since the Tank $43 \mathrm{H}$ feed pump, currently located at a height of 100 ", could not process liquid from the 64", 66", or 72" heights, these samples were not used in modeling. However, the Si concentrations from the January/February 2000 data were used in modeling the SRS 2H-Evaporator chemistry during the January 1996 to June 1997 time period when the Tank 43H feed pump was at a height of 64", at the top of the sludge and/or in the "Zone of Turbidity" that is rich in Al, Si, Fe, Mn, and U (Figure 6).

The chemistry of the supernate at and above the feed pump also appears different (Figure 6). The Si, Al, and Fe are higher at the 100" height than at the 201" (October 2000) or a 350 " height (January/February 2000). However, there are only two VDS samples available for modeling during the operational period of the SRS 2H-Evaporator (HTF-028 from the feed tank and HTF 030 from the drop tank). ${ }^{4}$ The exact heights of these two VDS samples are not known, so the VDS population was not modeled. Only the surface dip sample population was modeled for the SRS $2 \mathrm{H}$-Evaporator feed tank and the drop tank (Table IV and Table V).

SOL

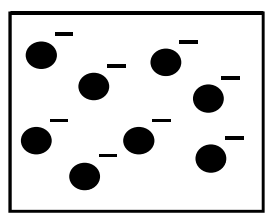

GEL

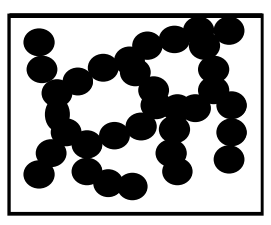

AMORPHOUS PRECIPITATE

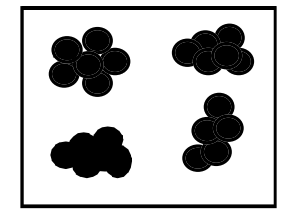

CRYSTALLINE PRECIPITATE

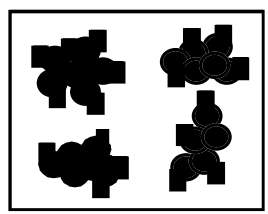

Figure 7. Pictorial diagram showing the differences between a sol, gel, and precipitate (after references 61 and 62) 


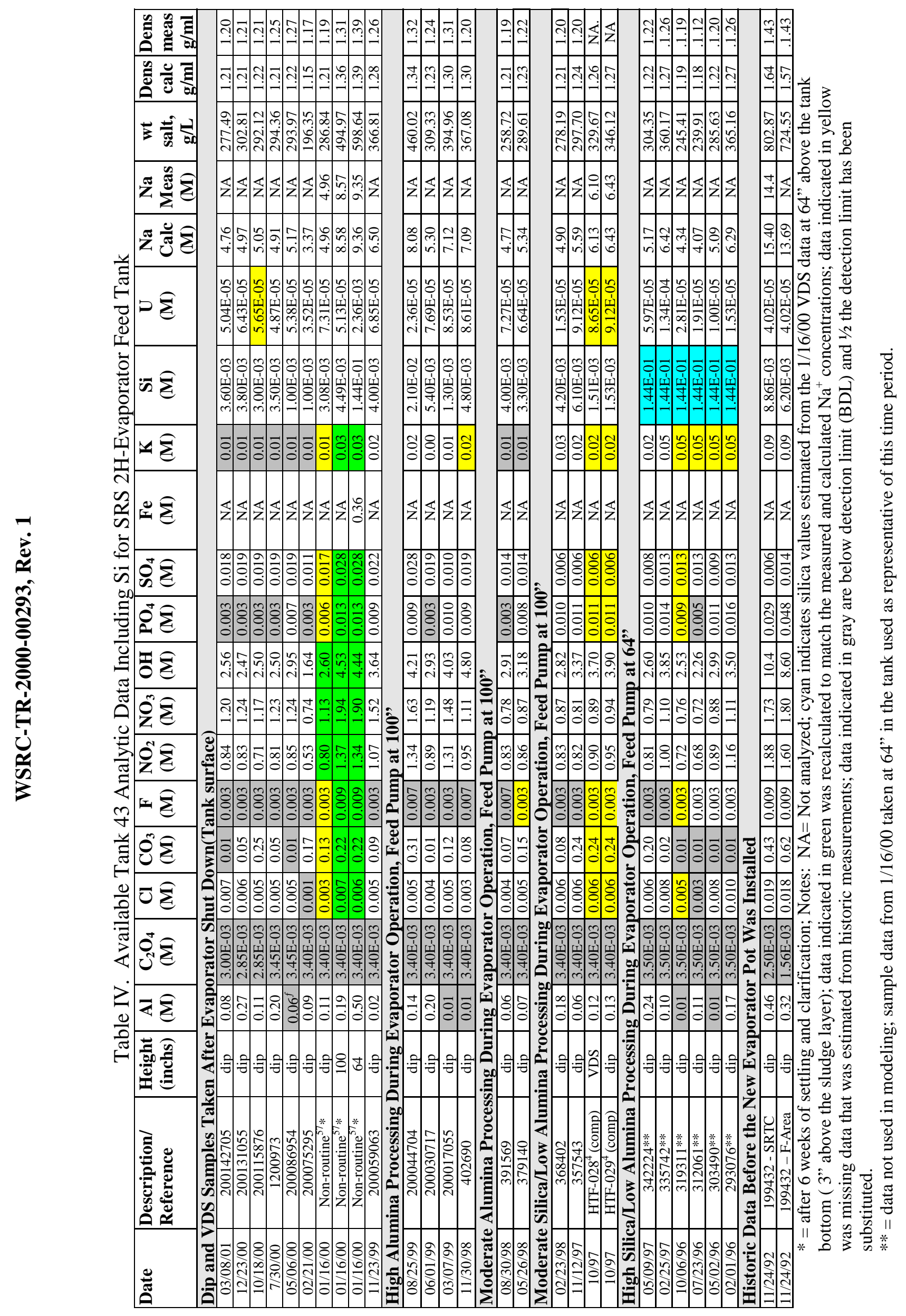




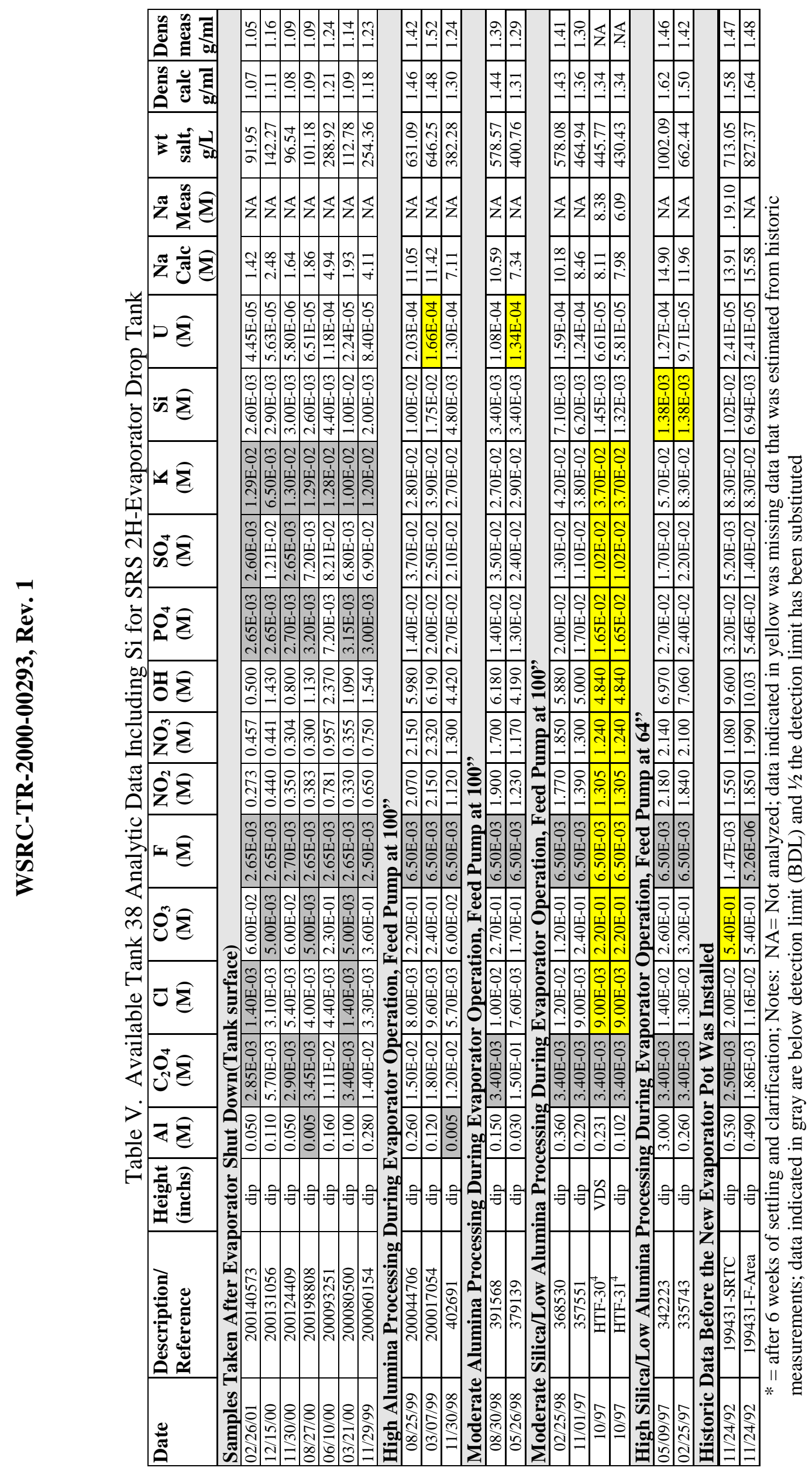




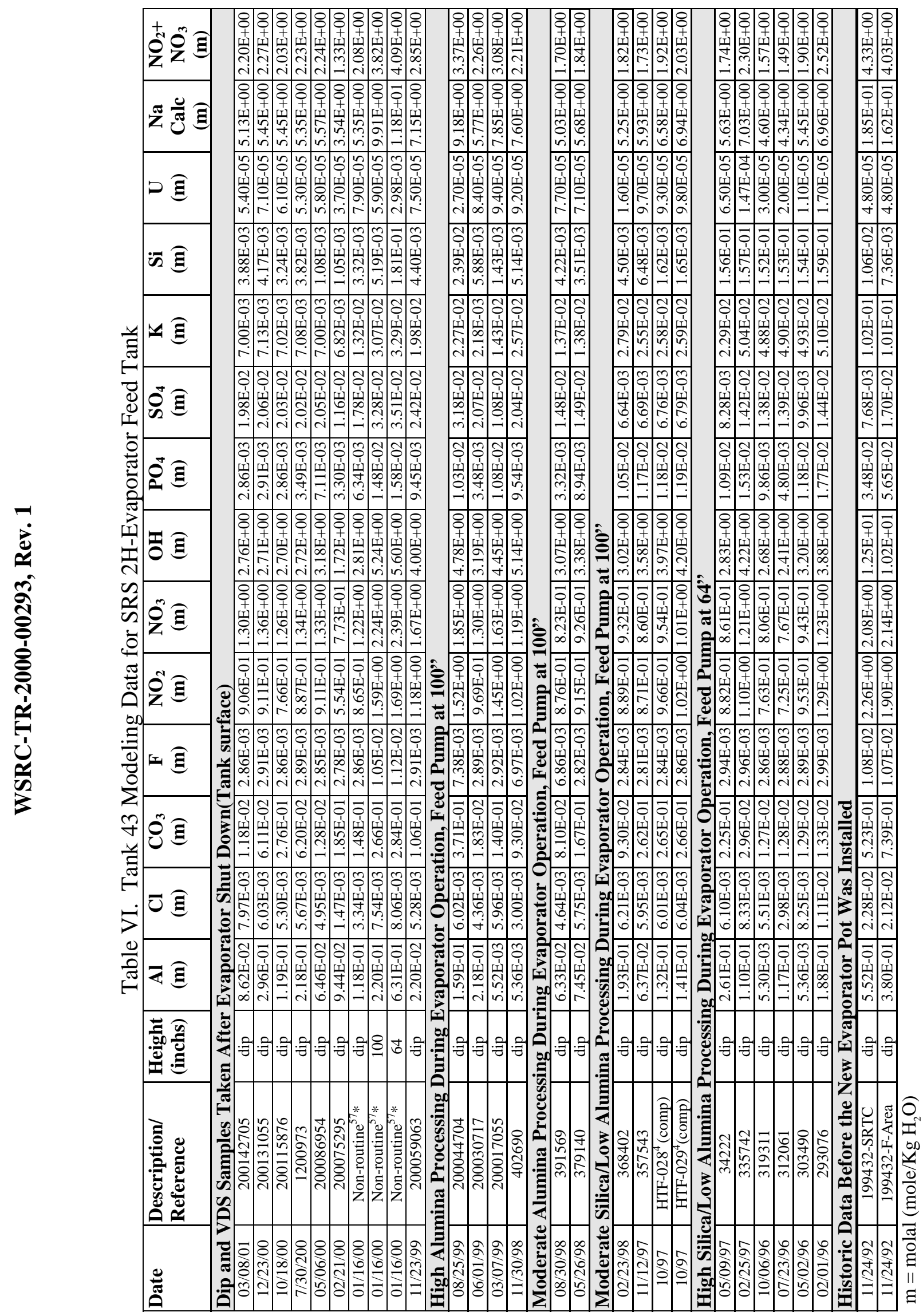




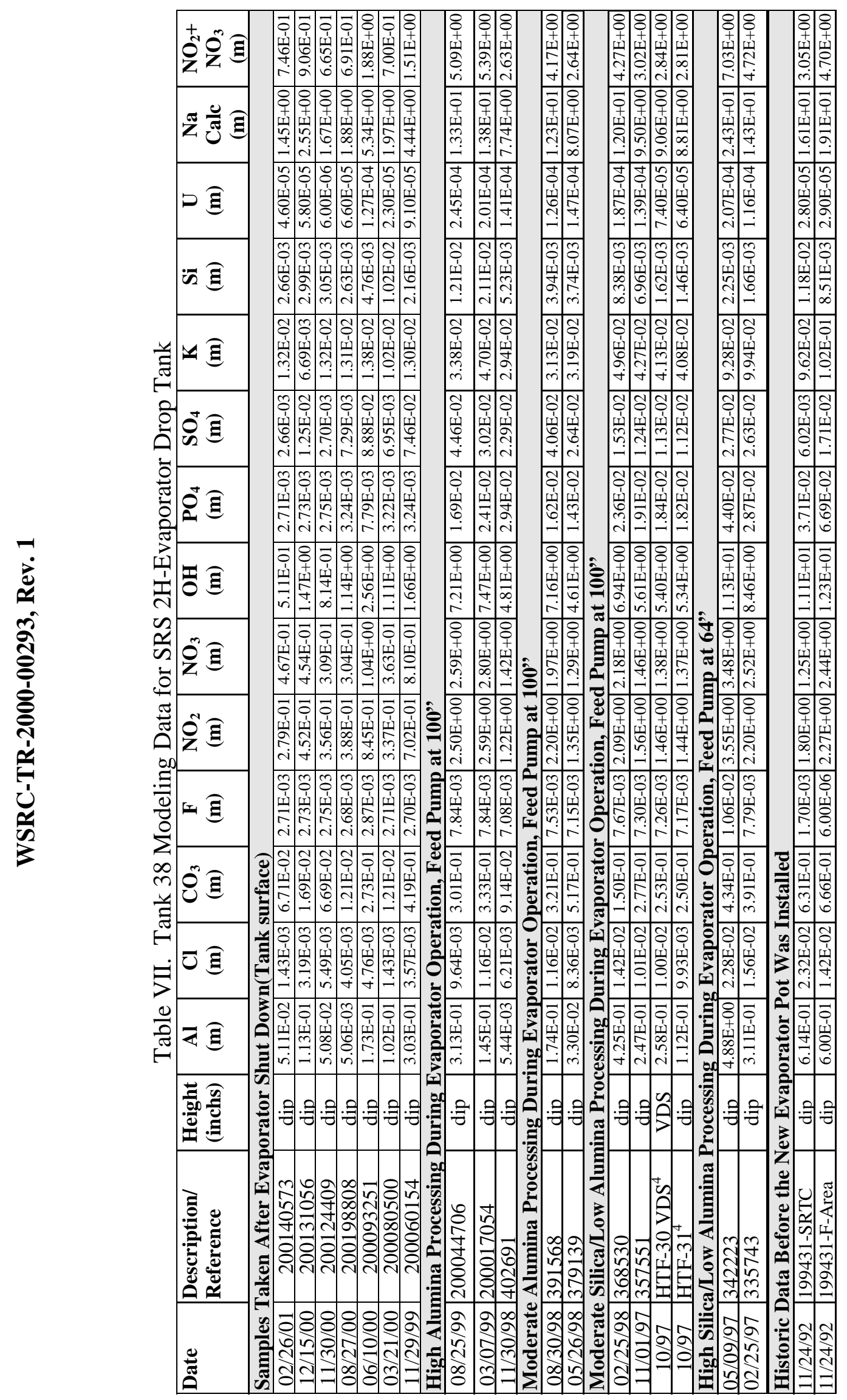

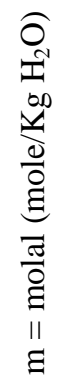




\section{WSRC-TR-2000-00293, Rev. 1}

\subsubsection{Time Populations}

The SRS 2H-Evaporator saw chemically diverse feed streams during the operational period between startup (January 1996) and shutdown (October 1999) as shown graphically in Figure 4. Since Figure 4 is based on the calculated amount of Si and Al in kilograms that was sent by DWPF and H-Canyon, respectively, an attempt was made to delineate distinct chemically diverse time populations. The cumulative sum chart shown in Figure 8 was constructed from the same data used to generate Figure 4 . The Si transfers from the DWPF that went to Tanks 21 and 22 are omitted for clarity since it was not clear from the operational morning reports if these solutions had been transferred back to Tank $43 \mathrm{H}$ and processed in the SRS $2 \mathrm{H}$-Evaporator.

The first time population observed is that of "high silica-low alumina" processing that is delineated between startup and the time at which the Tank $43 \mathrm{H}$ feed pump was raised out of the ZOT in June 1997. During this period there were numerous frit rich DWPF SME carryovers of large and moderate size (see Figure 4). These carryovers are responsible for the non-linear step in the Si cumulative sum curve shown in Figure 8. The Si cumulative curve is much higher than the Al cumulative sum curve. Two months after the non-linear step (April 1997) in the Si cumulative sum curve, the first deposits were observed in the SRS 2H-Evaporator (see Table III ). Two months after the high silica/low alumina processing ( 2 months after a new feed pump was installed at a level of 100") the GDL plugged (Table III).

The second time population shown in Figure 8 is that representing "moderate silica- low alumina" operations. This time period starts after the GDL was cleaned (August 1997), and defines an acceptable performance period for the SRS 2H-Evaporator. During this time period the DWPF had no SME carryovers, the feed pump had been raised to 100", and $\mathrm{H}$-canyon was sending minimum Al-rich solutions.

The third time population is defined as "moderate alumina" processing. This time population is defined by the initiation of large quantities of Al-rich solutions from $\mathrm{H}$ canyon (Figure 4) on or about April 4, 1998 by the steep break in the cumulative sum curve for Al (kgs) on Figure 8. This time population continues until November 1998 after which another steep break occurs in the cumulative sum curve for $\mathrm{Al}$ (kgs). The second GDL pluggage occurred 2 months after the "moderate alumina" processing time population was initiated. During this time flushing and pressure washing of the GDL caused many recycles from Tank $38 \mathrm{H}$ to Tank $43 \mathrm{H}$ and the evaporator pot was found to contain very turbid solutions (Table III).

The fourth time period is defined as "high alumina" operations and is defined by the break in the cumulative sum curve for $\mathrm{Al}$ (kgs) in November1998 until shutdown in October 1999. Toward the end of this time period (July to October 1999) there were as many as 90 flushes a month to maintain operation. All of the flushing caused tank agitation and solution turbidity. 
Two additional populations are modeled. These include 1992 historic data and data for the SRS 2H-Evaporator feed and drop tanks after shutdown of the SRS 2H-Evaporator. The time period after shutdown is modeled to demonstrate the current chemistry of the feed tanks and drop tanks with respect to saturation with the NAS phase. Modeling of this time period is not intended to assist with interpretation of the chemical combinations that caused the SRS 2H-Evaporator to become inoperable although it is intended to demonstrate when deposition may again occur.

Modeling time populations in the feed tank provided an average chemistry for each time period. The average chemistry is needed for modeling the phase boundaries on the activity diagrams. Once the boundaries are defined by this average chemistry, then the position of the data taken at different times can be overlain.

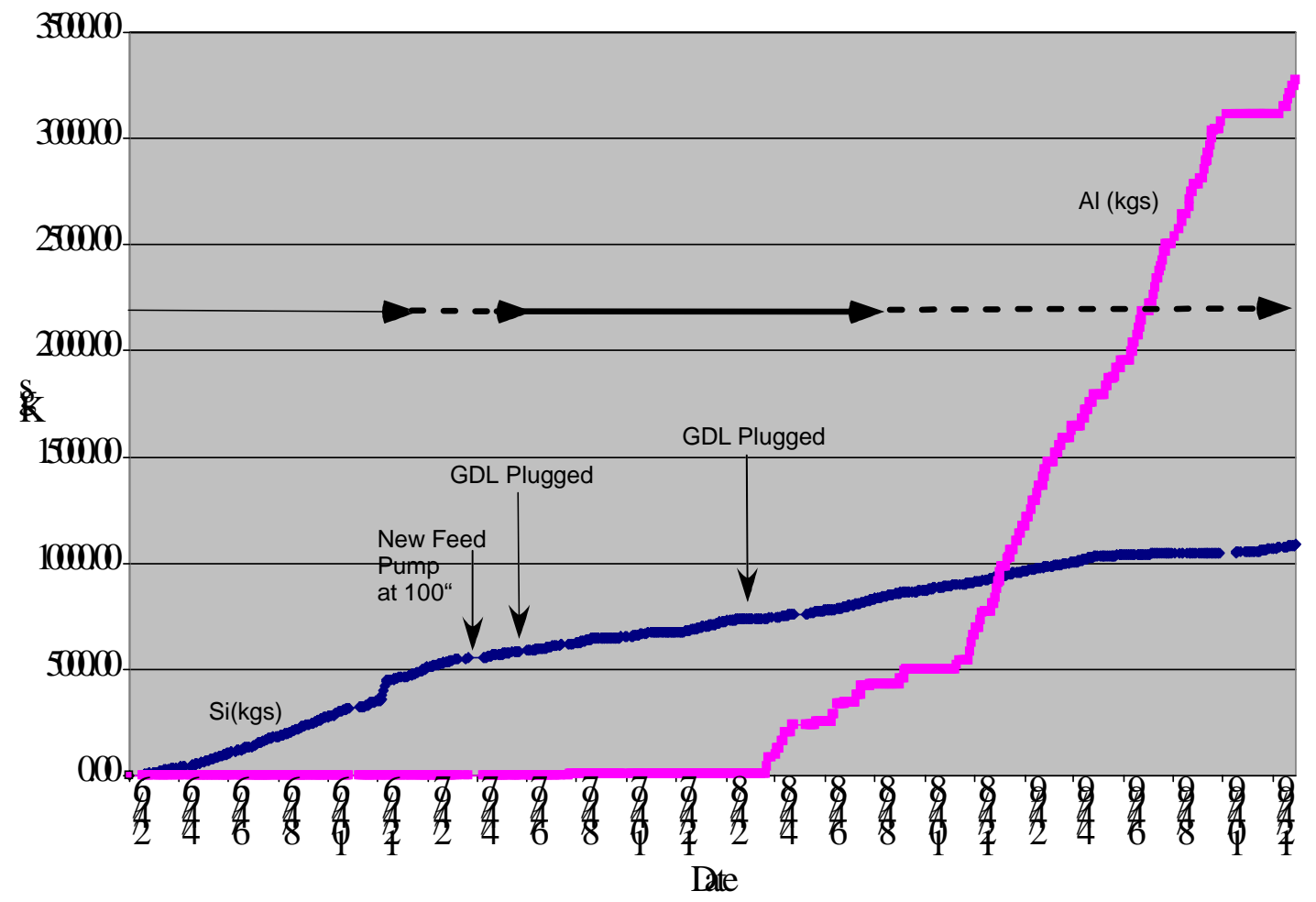

Figure 8. Cumulative sum chart of the $\mathrm{Si}(\mathrm{kgs})$ and $\mathrm{Al}(\mathrm{kgs})$ received by the SRS $2 \mathrm{H}$ Evaporator feed tank (Tank 43H). DWPF Si that was sent to Tanks 21 and Tanks 22 is omitted from this chart. Series 1 is the Si data while series 2 is the Al data. Superimposed are solid arrows indicating time periods when the evaporator was operting without scale being observed and without plugging. The dashed arrows indicate operating times when scale was observed and/or plugging was occurring. 
In order to demonstrate that turbidity due to frequent flushes and frequent recycles was important to the deposition of material in the SRS 2H-Evaporator, it is instructive to overlay the Si in kgs being sent to the evaporator from DWPF (from Figure 4) onto the measured $\mathrm{Si}(\mathrm{M})$ and $\mathrm{Al}(\mathrm{M})$ from dip samples taken in the feed and drop tanks (see Table IV and Table V). Such an overlay chart is shown in Figure 9 where the molar dip sample concentrations from Table IV and Table V have been multiplied by 10000 to show the trends more clearly. It is apparent from Figure 9 that there were large surges in $\mathrm{Si}$ concentration in the supernate in Tanks 43 and 38 at times when the DWPF was not discharging large amounts of $\mathrm{Si}$ in the form of SME carryovers. These time periods (August 1997) correspond to the time frame when the GDL was first flushed to the drop tank (Tank 38H) and (March to August 1999) when frequent flushes of the GDL, lift line and pot were occurring. This demonstrates how easily the ZOT can be perturbed and resuspend $\mathrm{Si}$ into the supernate.

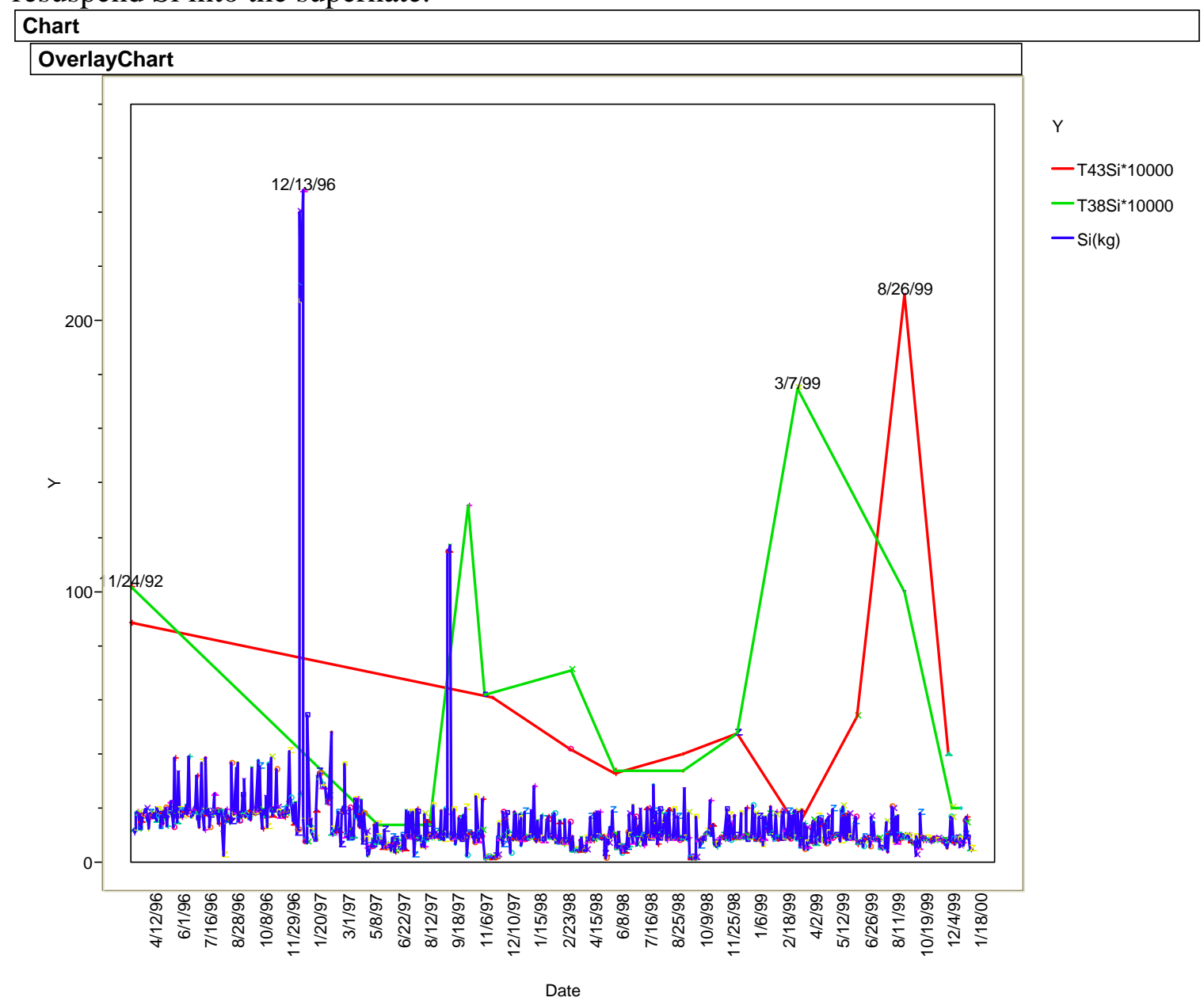

Figure 9. Overlay of $\mathrm{Si}(\mathrm{M}) * 10000$ for the SRS 2H-Evaporator Feed amd Drop Tanks overlain on the Si(kgs) known to be sent from DWPF to the evaporator. The feed tank data is indicated in red by circles, the drop tank data is indicated in green by plus symbols, and the $\mathrm{Si}$ in $\mathrm{kgs}$ is indicated in blue. 


\subsection{MODELING APPROACH}

The molar tank compositions given in Table IV and Table V were converted into molal units which are the units of preference in the GWB software. The conversion formula takes the form ${ }^{5}$

$$
\left[\mathrm{i}^{+/-}\right]_{\mathrm{m}}=\frac{\left[\mathrm{i}^{+/-}\right]_{\mathrm{M}}}{\rho-\sum \rho_{\text {solutes }}}
$$

where $\left[\mathrm{i}^{+/-}\right]_{\mathrm{M}}$ and $\left[\mathrm{i}^{+/-}\right]_{\mathrm{m}}$ are the molar and molal concentrations of ionic species $\mathrm{i}$, respectively, $\rho$ is the solution density in $\mathrm{kg} / \mathrm{L}$, and $\Sigma \rho_{\text {solutes }}$ is the sum of the partial densities of the dissolved solids. The solution density is calculated using Equation 11 in Section 5.2. For each ionic species, the partial dissolved solids density is the product of its molarity and its ionic weight in $\mathrm{g} / \mathrm{mole}$. Ionic weights for the most prevalent species in basic solutions are used. These are $\mathrm{Al}(\mathrm{OH})_{4}^{-}, \mathrm{Cl}^{-}, \mathrm{CO}_{3}{ }^{2-}, \mathrm{F}^{-}, \mathrm{NO}_{2}^{-}, \mathrm{NO}_{3}^{-}, \mathrm{OH}^{-}, \mathrm{PO}_{4}{ }^{3-}$, $\mathrm{SO}_{4}{ }^{2-}, \mathrm{Fe}(\mathrm{OH})_{4}^{-}, \mathrm{K}^{+}, \mathrm{H}_{2} \mathrm{SiO}_{4}{ }^{2-},\left(\mathrm{UO}_{2}\right)_{3}(\mathrm{OH})_{7}{ }^{-}$, and $\mathrm{Na}^{+}$. Table VI and Table VII reflect the input data in molalities used for modeling.

Activity diagrams have the ability to graphically represent two, three, or four chemical parameters simultaneously. Each axis can represent one chemical species or each axis can represent two chemical species expressed as a ratio. Aluminum hydroxyanions and uranium oxycations were chosen for the ordinate in order to more closely represent the ion pairing expected in the high ionic strength solutions ${ }^{42}$ such as the solutions that exist in the evaporator. For the SRS evaporator modeling a ratio of hydroxyanions or oxycations divided by $\mathrm{H}^{+}$is expressed on the ordinate and a single species on the abscissa. This allows the effects of three chemical species on the phase stability to be diagramed simultaneously although all chemical species from Table VI and Table VII are entered during modeling. All solid phases are indicated in regular text on the activity/stability diagrams. All aqueous species are indicated in italics on the activity/stability diagrams.

In order to plot the stability fields of the aluminosilicate species, a representation of the activity $\mathrm{Al}(\mathrm{OH})_{4}^{-} / \mathrm{H}^{+}$was chosen for the ordinate and the activity of aqueous silica on the abscissa. The hydroxyanion $\mathrm{Al}(\mathrm{OH})_{4}^{-}$was chosen instead of $\mathrm{Al}^{3+}$ as the stable aqueous species present in the evaporator tank supernates at $\mathrm{pH}$ values of $13-14 . \mathrm{H}^{+}$was used to represent the $\mathrm{pH}$ effects. This representation was chosen because the stability of most aluminosilicates in the presence of aluminum in solution is a function of the amount of silica in solution and the $\mathrm{pH}$. The choice of aqueous silica activity as the abscissa variable follows standard practice used in geochemical literature.

In order to plot the stability fields of the uranates, a representation of the activity of $\mathrm{UO}_{2}^{++} / \mathrm{H}^{+}$was chosen for the ordinate and the activity of $\mathrm{CO}_{2}(\mathrm{aq})$ was chosen as the abscissa. The oxycation, $\mathrm{UO}_{2}^{++}$term, was chosen instead of the $\mathrm{U}^{4+}$ term as the most stable aqueous species to be present in the evaporator tank supernates at high $\mathrm{pH}$ in the absence of high carbonate. The $\mathrm{U}^{4+}$ is the basis species in GWB and all hexavalent uranium $\left(\mathrm{U}^{6+}\right)$ species are either oxycations like $\mathrm{UO}_{2}{ }^{++}$or hydroxyanions like 


\section{WSRC-TR-2000-00293, Rev. 1}

$\left(\mathrm{UO}_{2}\right)_{3}(\mathrm{OH})_{7}{ }^{-}$. The $\mathrm{H}^{+}$term was chosen to represent the $\mathrm{pH}$ effects. This representation was chosen as the stability of most sodium uranates in the presence of uranium is a function of the amount of carbonate in solution and the $\mathrm{pH}$. To ensure that the correct oxidation state of uranium was used throughout the modeling, the redox state of the system was controlled by swapping $\mathrm{O}_{2}$ (gas) for the GWB default $\mathrm{O}_{2}$ (aqueous) and setting the $\mathrm{O}_{2}$ (gas) fugacity at that of air, e.g. $0.21 \mathrm{~atm}$.

Data for the solubility of sodium diuranate $\left(\mathrm{Na}_{2} \mathrm{U}_{2} \mathrm{O}_{7}\right)$ as a function of temperature was already in the GWB database. However, there is limited solubility data for amorphous $\mathrm{SiO}_{2}$ and $\mathrm{Al}(\mathrm{OH})_{3}$ in very basic high ionic strength solutions such as those in the SRS $2 \mathrm{H}-$ Evaporator. Comparison with available $\mathrm{SiO}_{2}$ solubility data in the literature showed that the solubility data used in GWB appears to adequately represent amorphous $\mathrm{SiO}_{2}$ equilibria in basic pH. GWB has the mononuclear silicate species $\mathrm{H}_{4} \mathrm{SiO}_{4}$ called $\mathrm{SiO}_{2}(\mathrm{aq})$, $\mathrm{H}_{3} \mathrm{SiO}_{4}^{-}$and $\mathrm{H}_{2} \mathrm{SiO}_{4}^{2-}$ of which the $\mathrm{H}_{2} \mathrm{SiO}_{4}^{2-}$ species is the most prevalent at $\mathrm{pH}$ values $>13$. $^{63} \mathrm{GWB}$ also contains the two most abundant ${ }^{64,63}$ polynuclear silicate species, the tetrameric $\mathrm{H}_{4}\left(\mathrm{H}_{2} \mathrm{SiO}_{4}\right)_{4}^{4-}$ and $\mathrm{H}_{6}\left(\mathrm{H}_{2} \mathrm{SiO}_{4}\right)_{4}{ }^{2-}$ of which the tetrameric $\mathrm{H}_{4}\left(\mathrm{H}_{2} \mathrm{SiO}_{4}\right)_{4}^{4-}$ is the most prevalent species at $\mathrm{pH}$ values $>13$. ${ }^{63}$ Polynuclear $\mathrm{Si}(\mathrm{IV})$ species are only significant at $\mathrm{pH}>10$ and a total dissolved Si concentrations larger than $10^{-3} \mathrm{M}^{65}$ In addition, the significance of the polynuclear $\mathrm{Si}(\mathrm{IV})$ species tends to decrease with increasing temperature. $^{66}$ Since the SRS $2 \mathrm{H}$-Evaporator Si concentrations are $\sim 10^{-3} \mathrm{M}$ concentration range (Table IV and Table V) and the polynuclear Si(IV) species are of minimal importance at the elevated evaporator operating temperatures, the absence of the remaining polynuclear $\mathrm{Si}(\mathrm{IV})$ species in the GWB database is not considered to significantly impact the modeling. This is discussed in more detail in Appendix B.

Examination of the gibbsite solubility data in GWB with that in the literature indicated that Russell's ${ }^{67}$ solubility data at a sodium molality of 8.5 would be more appropriate for modeling at the high ionic strength of the SRS evaporators. The Russel solubility data for gibbsite (alpha aluminum oxide trihydrate) and diaspore (alpha aluminum oxide monohydrate) was added to GWB database and designated as "gibbsite-M" and "diaspore-M" to distinguish these modified aluminum hydroxides from the gibbsite and diaspore solubility already in GWB. The Russel gibbsite-M and diaspore-M were used for modeling the SRS 2H-Evaporator solutions. Figure 10 demonstrates how the usage of gibbsite-M and diaspore-M from Russel impacts the activity diagram representation.

The data for the solubility of $\mathrm{NaAlO}_{2}$ and $\mathrm{AlO}_{2}^{-2}$ of Reynolds and Herting ${ }^{68}$ were also added to GWB for completeness. Detailed descriptions of the manner in which the data were added to the GWB database appear in Appendix B.

The data of $\mathrm{Ejaz}^{22}$ for the solubility of the NAS ${ }_{\text {gel }}$ and Zeolite-A was added to the GWB database as was the data of Gasteiger ${ }^{17}$ for Zeolite-A mixed with cancrinite, hereafter referred to as "mixed zeolite." Ejaz measured solubilities by dissolving Zeolite-A and $\mathrm{NAS}_{\text {gel }}$ precipitate in 3.02, 3.32, 3.89, and 4.39 molar $\mathrm{NaOH}$ solutions. Temperatures for the Ejaz measurements were $30^{\circ} \mathrm{C}, 50^{\circ} \mathrm{C}, 65^{\circ} \mathrm{C}$, and $80^{\circ} \mathrm{C}$. At the highest temperature and concentration, the NAS solubilities decreased significantly. Ejaz attributed this 
WSRC-TR-2000-00293, Rev. 1
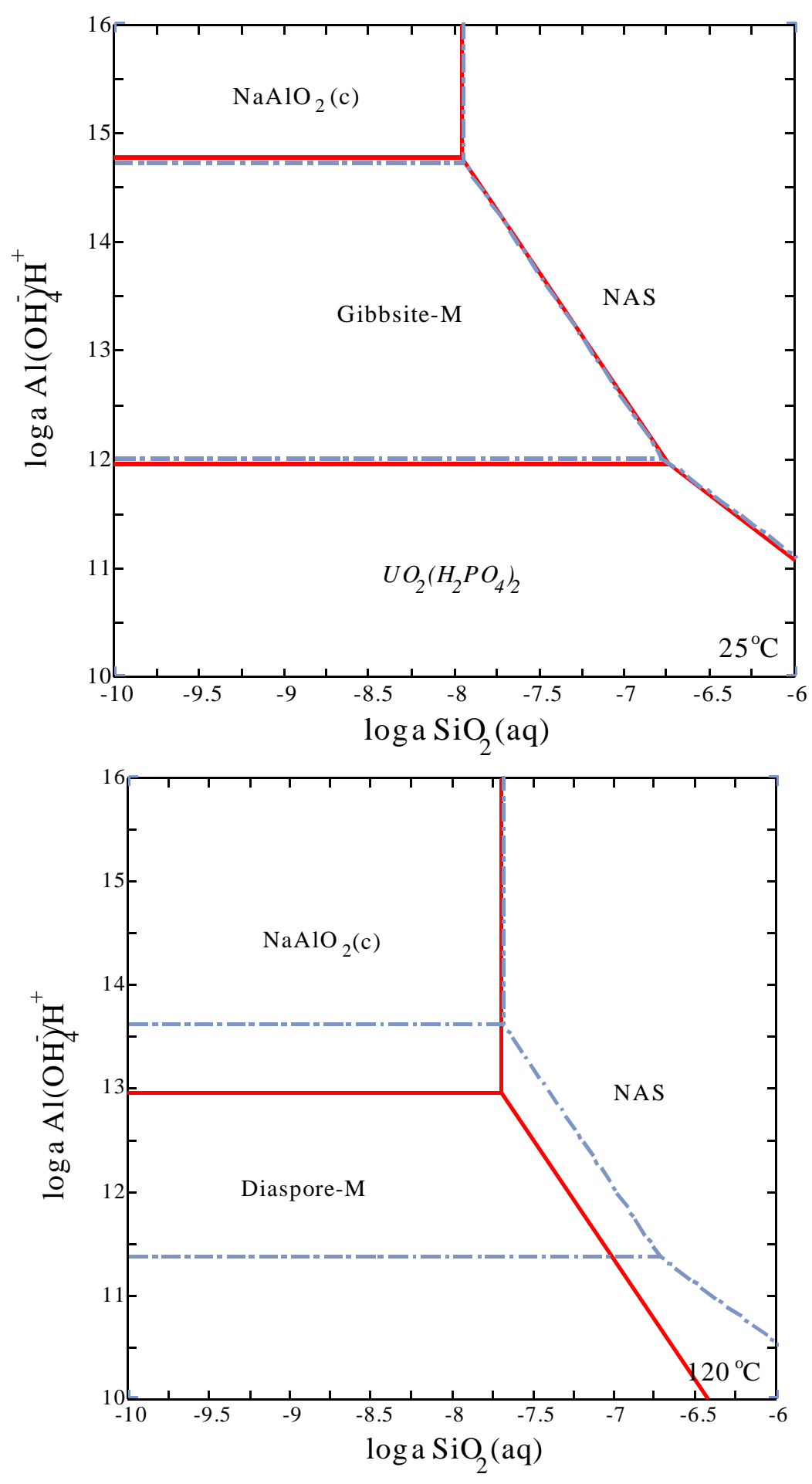

Figure 10. Activity diagram showing how the stability boundaries for gibbsite and diaspore change when the solubility data of Russell ${ }^{67}$ (bottom) measured at 8.5 molal $\mathrm{Na}$ is substituted for the $\mathrm{Al}(\mathrm{OH})_{3}$ and $\mathrm{AlOOH}$ data in $\mathrm{GWB}$ (top). 


\section{WSRC-TR-2000-00293, Rev. 1}

decrease to crystallization of zeolites from solution. Ejaz's data for the $\mathrm{NAS}_{\mathrm{gel}}$ and Zeolite-A were extrapolated to a sodium molarity of 8.5 appropriate to the SRS evaporator solutions. This extrapolation is discussed in greater detail in Appendix B.

Gasteiger measured "mixed zeolite (MZ)" solubilities by observing rates of precipitation from green liquor ${ }^{\S}$ solutions that were supersaturated with aluminates and silicates. The Gasteiger measurements were restricted to one temperature, $95^{\circ} \mathrm{C}$, so it was not possible to determine an activation energy for the variation of solubility with temperature. In the absence of this information, the measured mixed zeolite solubility at $95^{\circ} \mathrm{C}$ was combined with a weighted average of the activation energies for the $\mathrm{NAS}_{\mathrm{gel}}$ and Zeolite-A. A

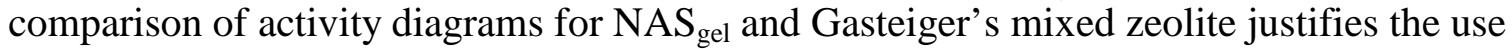
of this activation energy. This comparison showed that the $\mathrm{NAS}_{\mathrm{gel}}$ and the mixed zeolites had nearly identical aluminate and silicate solubilities at $95^{\circ} \mathrm{C}$. This suggests that the mixed zeolites in Gasteiger's tests formed from an $\mathrm{NAS}_{\text {gel }}$ precursor, which controlled the measured solubilities.

The mixed zeolite data was extrapolated to a sodium molarity of 8.5 appropriate to the SRS evaporator solutions. The extrapolation is discussed in greater detail Appendix B.

Similarly, Park and Englezos ${ }^{69}$ measured the solubility of hydroxysodalite by observing rates of precipitation from green liquor and white liquor $\S$ solutions that were supersaturated with aluminates and silicates. Park and Englezos specifically studied the effects of $\left[\mathrm{OH}^{-}\right],\left[\mathrm{CO}_{3}{ }^{2-}\right],\left[\mathrm{SO}_{4}^{2-}\right]$ and $\mathrm{Na}_{2} \mathrm{~S}$ on the precipitation of aluminosilicates in highly alkaline solutions. Their solubility measurements were ranged from 2.0 to 3.0 molal $\mathrm{NaOH}$. The hydroxysodalite data was extrapolated to a sodium molarity of 8.5 appropriate to the SRS evaporator solutions. The extrapolation is discussed in greater detail Appendix B.

The appearance/precipitation of the NAS ${ }_{\text {gel }}$ appears to be the kinetically most rapid step in the sequential formation of $\mathrm{NAS}_{\text {gel }} \rightarrow$ Zeolite-A $\rightarrow$ sodalite $\rightarrow$ cancrinite. The $\mathrm{NAS}_{\text {gel }}$ is the least dense and most soluble phase. The density and stoichiometry of the different phases causes them to have different relative solubilities and different boundary positions on an activity diagram (Figure 11). Since the operating strategy for the SRS evaporators is to avoid any potential to form nitrated sodalite/cancrinite or any of the precursor phases, modeling of the NAS phase boundary in the activity diagrams is logical, e.g. the sodalite/cancrinite cannot form unless the precursor gel forms (see discussion in Section 2.3). Modeling the evaporator chemistry in terms of supersaturation with respect to the $\mathrm{NAS}_{\text {gel }}$ phase is also appropriate because the individual phase transformations from $\mathrm{NAS}_{\text {gel }} \rightarrow$ Zeolite-A $\rightarrow$ sodalite $\rightarrow$ cancrinite are not reversible.

The first step in preparing activity diagrams is to enter the average molal concentration of the ionic species for each set of measured tank chemistries in a given depth population

$\S \quad$ "Green liquor" is a term from the pulp and paper industry that describes solutions that dissolve wood pulp. Green liquor is a basic solution that contains sodium carbonates, sodium sulfides, and a small amount of sodium sulfates.

$\S \quad$ ("White liquor" is another term from the pulp and paper industry that describes solutions that dissolve wood pulp). 
into the GWB REACT subroutine. Equilibrium with air is specified by entering the oxygen fugacity of air as a constant. This allows the oxidation states of iron, uranium, etc. to be speciated for solutions in equilibrium with air in the calculations. REACT outputs the pertinent activities of all ionic species. To account for the mineral equilibrium under supersaturated conditions, no minerals are allowed to precipitate during the REACT calculation. The activities calculated in REACT from the solution concentrations are then used in the ACT2 subroutine to calculate the activity diagrams. This ensures that individual data points from each population are plotted on the activity diagram calculated from their pooled average chemistry. This approach is discussed in Appendix B.

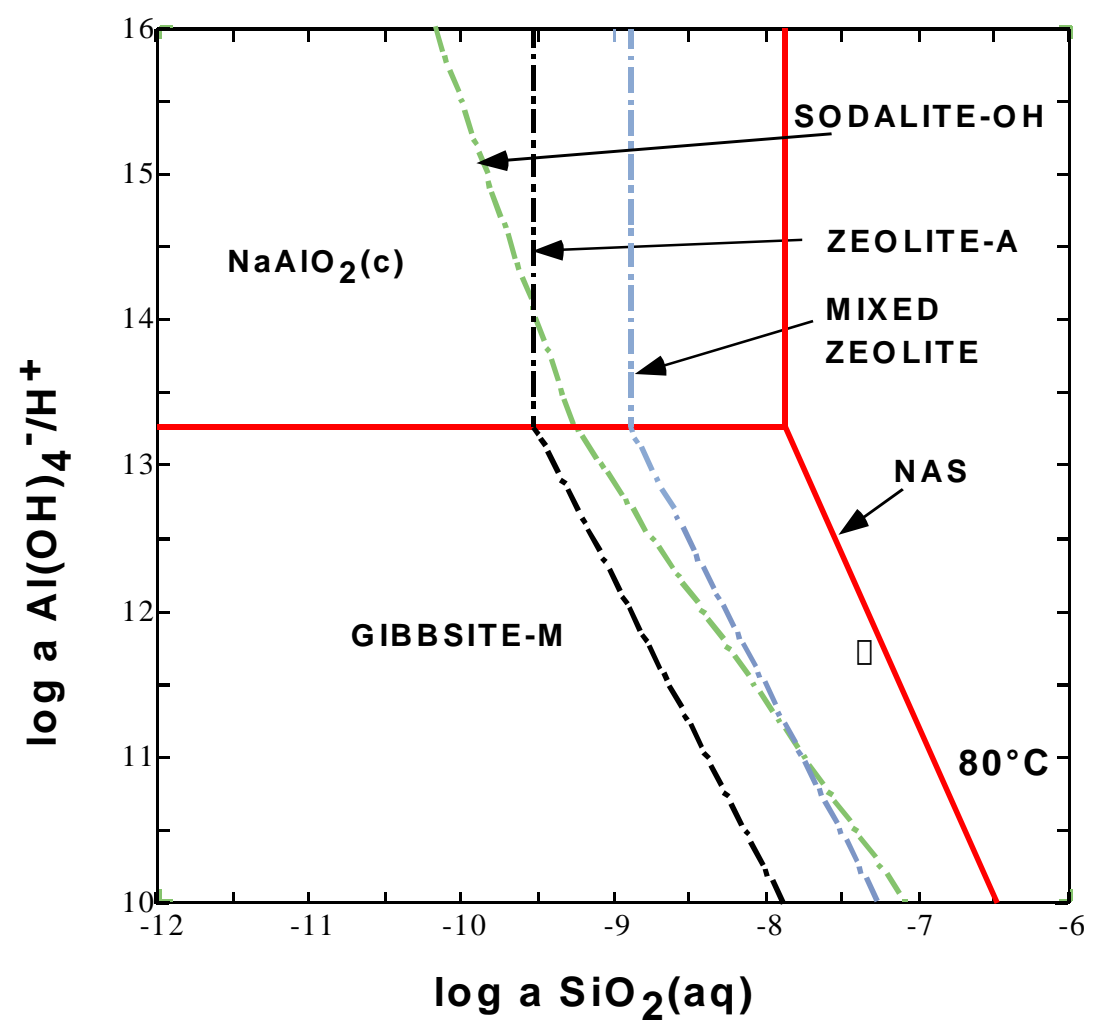

Figure 11. Relative Stability Boundaries of NAS ${ }_{\text {gel }}$, "mixed zeolite," Zeolite-A and hydroxysodalite.

\subsection{ACTIVITY DIAGRAMS FOR THE SRS 2H-Evaporator}


Activity diagrams were generated at $25^{\circ} \mathrm{C}$, which represents the temperature at which the tank solutions were analyzed. In order to evaluate the solution equilibria at the elevated temperature $\left(40^{\circ} \mathrm{C}\right)$ of the feed and drop tanks, the solution temperature was incrementally increased, using the polythermal reaction option in GWB. Separate calculations were performed to generate activity diagrams at the estimated evaporator temperature of $120^{\circ} \mathrm{C}$. For operation of the SRS $2 \mathrm{H}$-Evaporator, in which little to no salt precipitates, the target density is between $1.4-1.45 \mathrm{~g} / \mathrm{cm}^{3}$. Historically, during receipt of DWPF recycle, the density of the SRS $2 \mathrm{H}$-Evaporator solutions was in the $1.2-1.3 \mathrm{~g} / \mathrm{cm}^{3}$ range.

The aluminosilicate and uranium activity diagrams will be discussed in terms of the time populations defined in Figure 8 and Table VIII. Each diagram within a given time population will be described at $25^{\circ} \mathrm{C}, 40^{\circ} \mathrm{C}$, and $120^{\circ} \mathrm{C}$. These three temperatures represent the temperature at which the tank solutions were analyzed, the temperature at which the tank solutions were sampled, and the temperature that the solutions experienced when fed to the SRS 2H-Evaporator.

Table VIII. Chemically Distinct Time Populations Experienced in the SRS 2HEvaporator

\begin{tabular}{|l|l|l|l|}
\hline Feed Chemistry & Characteristics & Time Population & $\begin{array}{l}\text { Evaporator } \\
\text { Operation }\end{array}$ \\
\hline High Si, low Al & $\begin{array}{l}\text { Frequent large } \\
\text { DWPF SME } \\
\text { carryovers, little Al } \\
\text { from H-Canyon }\end{array}$ & $\begin{array}{l}\text { January 1996-June } \\
1997\end{array}$ & $\begin{array}{l}\text { New pot; operations } \\
\text { OK until first } \\
\text { evidence of scaling } \\
\text { (4/97); feed pump } \\
\text { at 64" }\end{array}$ \\
\hline Moderate Si, low Al & $\begin{array}{l}\text { Few SME } \\
\text { carryovers, some } \\
\text { without frit, little } \\
\text { Al from H-Canyon }\end{array}$ & $\begin{array}{l}\text { August 1997-March } \\
1998\end{array}$ & $\begin{array}{l}\text { New feed pump at } \\
\text { 100"; GDL plugs } \\
\text { (8/97); remaining } \\
\text { operations OK }\end{array}$ \\
\hline Moderate Al, moderate Si & $\begin{array}{l}\text { No SME } \\
\text { carryovers, } \\
\text { moderate Al from } \\
\text { H-Canyon }\end{array}$ & $\begin{array}{l}\text { April 1998- } \\
\text { December 1998 } \\
\text { time (6/98); } \\
\text { deposits on coils } \\
\text { and walls (6/98 + } \\
\text { 9/98) }\end{array}$ \\
\hline High Al, moderate Si & $\begin{array}{l}\text { No SME } \\
\text { carryovers, high Al } \\
\text { from H-Canyon }\end{array}$ & $\begin{array}{l}\text { December 1998- } \\
\text { October 1999 }\end{array}$ & $\begin{array}{l}\text { Significant deposits } \\
\text { on all internals }\end{array}$ \\
\hline
\end{tabular}

At ambient temperature the $\mathrm{NAS}_{\text {gel }}$ phase, gibbsite, $\mathrm{Al}(\mathrm{OH})_{3}$, and $\mathrm{NaAlO}_{2} \bullet 1.25 \mathrm{H}_{2} \mathrm{O}$ are the stable solid phases. Note that $\mathrm{Al}(\mathrm{OH})_{3}$ is not found to precipitate in the evaporator as the evaporator residence times are too short compared to the kinetic formation time necessary to precipitate gibbsite. However, the $\mathrm{NAS}_{\mathrm{gel}}$ is in equilibrium with $\mathrm{Al}(\mathrm{OH})_{3}$ in 


\section{WSRC-TR-2000-00293, Rev. 1}

solution and/or amorphous $\mathrm{Al}(\mathrm{OH})_{3}$. Russell's solubility data for $\mathrm{Al}(\mathrm{OH})_{3}$ was used in the modeling of the SRS $2 \mathrm{H}$-Evaporator ${ }^{67}$ rather than the $\mathrm{Al}(\mathrm{OH})_{3}$ data in $\mathrm{GWB}$. The $\mathrm{NaAlO}_{2} \bullet 1.25 \mathrm{H}_{2} \mathrm{O}$ phase is found in the SRS salt deposits, otherwise, the $\mathrm{NaAlO}_{2}$ is part of the dissolved solids in the tank solutions.

At the elevated temperatures in the evaporator, denser aluminate phases such as diaspore $(\mathrm{AlOOH})$ are stable rather than gibbsite and a mixed zeolite phase (partially crystallized with respect to sodalite/cancrinite) will likely be more stable than the $\mathrm{NAS}_{\text {gel }}$. The kinetics of diaspore formation in the evaporator are also kinetically slow and it is precluded from precipitating during the short evaporator residence times.

\subsection{Initial Operations (High and Moderate Si, low Al)}

The initial operations of the new SRS 2H-Evaporator pot is divided into two time populations, the high $\mathrm{Si}$, low $\mathrm{Al}$ and Moderate $\mathrm{Si}$, low $\mathrm{Al}$ time periods, delineated in Table VIII. These two time periods span the "low Al" operations and will be compared to the "high Al" operations in Section 6.1.2. During the high Si, low Al time regime the recently started DWPF was to have frequent large and moderate SME carryovers but there was little $\mathrm{Al}$ coming from $\mathrm{H}$-canyon although there was Al rich solutions in Tank $43 \mathrm{H}$ from previous $\mathrm{H}$-canyon campaigns. Operations were satisfactory with the new pot although the feed pump was in or near the ZOT until April 1997 when the first deposition (scaling) was observed in the evaporator pot. During the moderate $\mathrm{Si}$, low Al time regime, the DWPF had begun to control the SME carryovers and there were few to none. The $\mathrm{H}$-canyon was still sending minimum $\mathrm{Al}$ to Tank $43 \mathrm{H}$.

The phase boundaries plotted in Figure 12, Figure 14, Figure 16, and Figure 18 represent the feed tank (Tank 43H) average concentrations for the moderate Si/low Al time regime spanning between August 1997 and April 1998 (Table IV) when the new feed pump had been installed at a height of 100". The phase boundaries from the time period when the old feed pump had been at 64" in the ZOT could not be plotted since the Si numbers are silica values estimated from the January 2000 VDS sample taken at a height of 64" in the tank. The data from when the feed pump was at 64" is, therefore, overlain on the phase boundaries derived from when the feed pump was at 100". In order to perform a direct comparison of the feed tank and drop tank chemistries, the same time regimes were used to calculate the phase boundaries for the drop tank (Tank 38H) in Figure 13, Figure 15, Figure 17, and Figure 19.

At $25^{\circ} \mathrm{C}$ and $40^{\circ} \mathrm{C}$ the equations governing the equilibrium between gibbsite and $\mathrm{NaAlO}_{2}$ are the following:

\$ To generate these plots, $\mathrm{Al}(\mathrm{OH})_{4}{ }^{-} / \mathrm{H}^{+}$was swapped for the basis species $\mathrm{Al}^{3+}$ in the GWB software while $\mathrm{SiO}_{2}(\mathrm{aq})$ is a basis species. Since the basis species $\mathrm{Al}^{3+}$ and $\mathrm{SiO}_{2}(\mathrm{aq})$ have already been swapped as the ordinate and the abcissa variables, the aluminosilicate phase being modeled must be swapped for either $\mathrm{H}+, \mathrm{Na}^{+}$or $\mathrm{NO}_{3}{ }^{-}$. Hydroxysodalite and Zeolite-A do not contain nitrate groups, so only $\mathrm{Na}^{+}$and $\mathrm{H}^{+}$need to be considered for swapping. Either representation can be used 


$$
\operatorname{Gibbsite}(w)+\frac{\mathrm{Al}(\mathrm{OH})_{4}^{-}}{\mathrm{H}^{+}}+2 \mathrm{Na}^{+} \Leftrightarrow 2 \mathrm{NaAlO}_{2}(\mathrm{c})+3 \mathrm{H}_{2} \mathrm{O}
$$

For comparison, the remaining equations governing the equilibrium between the phases at $25^{\circ} \mathrm{C}$ and $40^{\circ} \mathrm{C}$ are:

between gibbsite and $\mathrm{UO}_{2}\left(\mathrm{H}_{2} \mathrm{PO}_{4}\right)_{2}$

$$
\begin{aligned}
& 6 \mathrm{UO}_{2}\left(\mathrm{H}_{2} \mathrm{PO}_{4}\right)_{2}+19 \frac{\mathrm{Al}(\mathrm{OH})_{4}^{-}}{\mathrm{H}^{+}} \Leftrightarrow 19 \operatorname{Gibbsite}(\mathrm{w})+5 \mathrm{H}_{2} \mathrm{O}+2\left(\mathrm{UO}_{2}\right)_{3}(\mathrm{OH})_{7}^{-} \\
& +12 \mathrm{PO}_{4}^{3-}
\end{aligned}
$$

between gibbsite and NAS is

$$
6 \operatorname{Gibbsite}(\mathrm{w})+13 \mathrm{H}_{2} \mathrm{O}+6 \frac{\mathrm{Al}(\mathrm{OH})_{4}^{-}}{\mathrm{H}^{+}}+14 \mathrm{SiO}_{2}(\mathrm{aq})+12 \mathrm{Na}^{+} \Leftrightarrow \mathrm{NAS}
$$

between $\mathrm{NaAlO}_{2}$ and NAS is

$$
12 \mathrm{NaAlO}_{2}(\mathrm{c})+31 \mathrm{H}_{2} \mathrm{O}+14 \mathrm{SiO}_{2}(\mathrm{aq}) \Leftrightarrow \mathrm{NAS}
$$

between $\mathrm{UO}_{2}\left(\mathrm{H}_{2} \mathrm{PO}_{4}\right)_{2}$ and NAS is

$$
\begin{aligned}
& 36 \mathrm{UO}_{2}\left(\mathrm{H}_{2} \mathrm{PO}_{4}\right)_{2}+217 \mathrm{H}_{2} \mathrm{O}+228 \frac{\mathrm{Al}(\mathrm{OH})_{4}^{-}}{\mathrm{H}^{+}}+266 \mathrm{SiO}_{2}(\mathrm{aq})+228 \mathrm{Na}^{+} \Leftrightarrow \\
& 19 \mathrm{NAS}+12\left(\mathrm{UO}_{2}\right)_{3}(\mathrm{OH})_{7}^{-}+72 \mathrm{PO}_{4}^{3-}
\end{aligned}
$$

It should be noted that the analytic data from the tank farm contained enough $\mathrm{PO}_{4}$ that a stability field for aqueous $\mathrm{UO}_{2}\left(\mathrm{H}_{2} \mathrm{PO}_{4}\right)_{2}$ appeared at low $\frac{\mathrm{Al}(\mathrm{OH})_{4}^{-}}{H^{+}}$and low $\mathrm{SiO} 2(\mathrm{aq})$, see for example Figure 10, Figure 12-Figure 15, etc. As the $\mathrm{SiO}_{2}(\mathrm{aq})$ activity increased at low $\frac{\mathrm{Al}(\mathrm{OH})_{4}^{-}}{\mathrm{H}^{+}}$the field of aqueous $\mathrm{UO}_{2}\left(\mathrm{H}_{2} \mathrm{PO}_{4}\right)_{2}$ was replaced by the field of NAS.

Dip sample data from Tanks 43 and 38 analyzed by SRTC and F-area laboratory are overlain on Figure 12 to Figure 19. The majority of the silica data available for modeling

but swapping the aluminosilicate mineral species for $\mathrm{H}^{+}$in the basis species allows the field of gibbsite, $\mathrm{Al}(\mathrm{OH})_{3}$ to be represented while swapping for $\mathrm{Na}^{+}$in the basis species allows the fields of various sodium silicates to be represented. Since the mass balance of the evaporator deposits indicated excess $\mathrm{Al}(\mathrm{OH})_{3}$ to be present, it was decided to use the representation that showed the gibbsite/aluminosilicate boundary, e.g. the pertinent aluminosilicate mineral phase was swapped for the $\mathrm{H}^{+}$basis species. This means that Equations 12-19 are balanced on NAS instead of $\mathrm{H}^{+}$and on $\mathrm{Al}(\mathrm{OH})_{4}{ }^{-} / \mathrm{H}^{+}$instead of $\mathrm{Al}^{3+}$. 


\section{WSRC-TR-2000-00293, Rev. 1}

the SRS 2H-Evaporator was from the F-Area laboratory and represents a worst case scenario since these analyses were shown to be biased high by $\sim 2 \mathrm{X}$ (Section 4.3 Part $\mathrm{I}^{3}$ ).

The dip sample data for Tank 43H, the feed tank, from 1992 to April 1998 is plotted in Figure 12 at the sample measurement temperature of $25^{\circ} \mathrm{C}$. The November $1992 \mathrm{dip}$ sample measured by SRTC is shown as a violet star while the blue square represents SRTC analysis of a composite dip sample taken over the time period January 1995 to December 1996. The data shown by the red hourglass symbol is the chemistry estimated to be representative of the feeds sent to the evaporator when the feed pump was at 64" in the ZOT (January 1996 to June 1997): the data were estimated from the analysis taken in January 2000 at a height of 64" in Tank 43H (Table IV) as discussed above. Comparison of the relative positions of the blue square and the red hourglass demonstrates that the dip sample analyses for the composite (blue square) are indicating that the feed pump was feeding Si depleted solutions to the SRS 2H-Evaporator when it was feeding Si rich feeds due to the proximity of the feed pump to the ZOT.

The Tank 43H dip sample data (black circles) represent the chemical analyses representative of the supernate, e.g. when the new feed pump was installed at a height of 100" after June 1997. The samples taken on 2/23/98 and 11/12/97 were analyzed by Farea laboratory and a composite sample, HTF-029, was analyzed by SRTC (see Table IV). Note that the sample (black circle) analyzed by SRTC in October 1997 (HTF-029) has a lower log a $\mathrm{SiO}_{2}$ (aq) than the remaining samples (black circles) analyzed by the Farea laboratory in November 1997 and February 1998.

Figure 12 demonstrates that the feed tank supernate (as evidenced by the dip sample data) was in equilibrium with respect to gibbsite in the 1992 time frame (star). After receipt of DWPF recycle at a height of 64" from the bottom of the tank (in or near the ZOT), Tank $43 \mathrm{H}$ was in local equilibrium with respect to the $\mathrm{NAS}_{\text {gel }}$ (red hourglass). From the initiation of feeding of the SRS 2H-Evaporator in January 1996, as long as the feed pump was in or near the ZOT, the evaporator feeds were saturated with respect to NAS. After the new feed pump was installed at 100" height, the feeds to the evaporator were no longer saturated with respect to NAS.

Figure 13 is a plot of the SRS 2H-Evaporator drop tank for the time periods corresponding to the feed tank chemistries shown in Figure 12. The drop tank (Tank $38 \mathrm{H}$ ) dip sample (star) was not saturated with respect to NAS in 1992. The supernate was not saturated with respect to NAS before the feed pump was raised (red diamonds) although Figure 12 demonstrates that deposition was probably occurring in the $2 \mathrm{H}$ Evaporator and/or in the GDL at this time. Note that the two samples (black circles) analyzed by SRTC in October 1997 (HTF-030 and 31) had a lower log a SiO 2 (aq) than the remaining samples (black circles) analyzed by the F-area laboratory in November 1997 and February 1998. The F-area laboratory data would indicate that the drop tank may have been just saturated with respect to NAS. However, given the high bias in the Farea laboratory results this is not likely.

Activity diagrams were generated at the nominal temperature $\left(40^{\circ} \mathrm{C}\right)$ of the SRS $2 \mathrm{H}$ Evaporator feed and drop tanks using the polythermal reaction option in GWB (Figure 14 50 


\section{WSRC-TR-2000-00293, Rev. 1}

and Figure 15). Similar to the findings in Figure 12 and Figure 13 at $25^{\circ} \mathrm{C}$, Tank $43 \mathrm{H}$ was supersaturated with respect to NAS during the high $\mathrm{Si}$ initial operations but not during the moderate Si initial operations. Tank $43 \mathrm{H}$ was also not supersaturated with respect to NAS in 1992. Indeed, the historic and moderate Si operations dip samples indicate saturation with respect to either gibbsite or $\mathrm{NaAlO}_{2}$.

Activity diagrams were generated at the elevated temperature $\left(120^{\circ} \mathrm{C}\right)$ of the SRS $2 \mathrm{H}$ Evaporator using the polythermal reaction option in GWB. The effects of elevated temperature on the relative phase stability fields are examined for solutions at a specific gravity of $\sim 1.45 \mathrm{~g} / \mathrm{cc}$, the nominal specific gravity achieved to in the $2 \mathrm{H}$-Evaporator. The effects of an additional evaporation of $40 \%$ that would yield evaporator solutions of $\sim 1.6$ specific gravity are not considered since the SRS $2 \mathrm{H}$-Evaporator never achieved these solution densities.

At the elevated temperature of $120^{\circ} \mathrm{C}$, the gibbsite phase, $\mathrm{Al}(\mathrm{OH})_{3}$ is no longer stable. The mineral diaspore $(\mathrm{AlOOH})$ is the stable alumina phase at $120^{\circ} \mathrm{C}$. The phase boundaries plotted in Figure 16 to Figure 19 represent the feed tank (Tank 43H) average concentrations for the moderate Si/low Al time regime spanning between August 1997 and April 1998 (Table IV) when the new feed pump had been installed at a height of 100". The pertinent equilibria between diaspore and NAS, diaspore and mized zeolite(MZ), $\mathrm{NaAlO}_{2}$, and $\mathrm{UO}_{2}\left(\mathrm{H}_{2} \mathrm{PO}_{4}\right)_{2}$ are:

$$
\begin{aligned}
& \text { 6Diaspore }+19 \mathrm{H}_{2} \mathrm{O}+6 \frac{\mathrm{Al}(\mathrm{OH})_{4}^{-}}{\mathrm{H}^{+}}+14 \mathrm{SiO}_{2}(\mathrm{aq})+12 \mathrm{Na}^{+} \Leftrightarrow \mathrm{NAS} \\
& 6 \text { Diaspore }+15 \mathrm{H}_{2} \mathrm{O}+6 \frac{\mathrm{Al}(\mathrm{OH})_{4}^{-}}{\mathrm{H}^{+}}+12 \mathrm{SiO}_{2}(\mathrm{aq})+12 \mathrm{Na}^{+} \Leftrightarrow \mathrm{MZ} \\
& \text { Diaspore }+\frac{\mathrm{Al}(\mathrm{OH})_{4}^{-}}{\mathrm{H}^{+}}+2 \mathrm{Na}^{+} \Leftrightarrow 2 \mathrm{NaAlO}_{2}(\mathrm{c})+2 \mathrm{H}_{2} \mathrm{O} \\
& 6 \mathrm{UO}_{2}\left(\mathrm{H}_{2} \mathrm{PO}_{4}\right)_{2}+19 \frac{\mathrm{Al}(\mathrm{OH})_{4}^{-}}{\mathrm{H}^{+}} \Leftrightarrow 19 \mathrm{Diaspore}^{+}+24 \mathrm{H}_{2} \mathrm{O}+2\left(\mathrm{UO}_{2}\right)_{3}(\mathrm{OH})_{7}^{-} \\
& +12 \mathrm{PO}_{4}^{3-}
\end{aligned}
$$

Ejaz. ${ }^{22}$ has suggested that the NAS phase may not be the stable phase at elevated temperature due to the rapid kinetics of the NAS transformation into Zeolite-A and other phases. This hypothesis was put forward by Ejaz although he did not have data to substantiate his position. A mixture of Zeolite-A and hydroxysodalite, such as that observed by Gasteiger et. al. ${ }^{17}$ at $95^{\circ} \mathrm{C}$ in evaporators in the paper and pulp industry, is more likely at $120^{\circ} \mathrm{C}$. Therefore, the activity diagrams for the SRS $2 \mathrm{H}$-Evaporator feed tank and the drop tank showing the equilibrium with $\mathrm{NAS}_{\text {gel }}$ are presented in Figure 16 and Figure 17 while the activity diagrams showing the equilibrium with the Gasteiger mixed zeolite are shown in Figure 18 and Figure 19. It should be noted that the solubility data of $\mathrm{Ejaz}^{22}$ for the $\mathrm{NAS}_{\mathrm{gel}}$ and the solubility data of Gasteiger ${ }^{17}$ are very similar and confirmatory of each other. However, each of these diagrams is based on solubility extrapolations as discussed in Appendix B, i.e. the solubility of the $\mathrm{NAS}_{\mathrm{gel}}$ has been extrapolated from the lower temperature measurements of Ejaz. ${ }^{22}$ For the mixed 


\section{WSRC-TR-2000-00293, Rev. 1}

zeolite phase of Gasteiger, ${ }^{17}$ solubility was available for only one temperature, $95^{\circ} \mathrm{C}$, and the temperature dependence of the solubility of the mixed zeolite was estimated using the activation energy of the $\mathrm{NAS}_{\mathrm{gel}}$.

At the elevated temperature of the SRS 2H-Evaporator the historic 1992 dip sample data and the dip sample data taken during the moderate silica/low alumina processing time period (Figure 16 and Figure 17) indicate that the evaporator solutions were not saturated with respect to the $\mathrm{NAS}_{\text {gel }}$ phase. This was the time period during which the feed pump was at 100" and the dip samples were representative of the solutions being fed to the evaporator. However, the feed tank (Tank $43 \mathrm{H})$ was saturated with respect to the NAS $\mathrm{Sel}_{\mathrm{g}}$ phase during the high Si initial operations when the feed pump was at or near the ZOT. Conversley, the red hourglass shown in Figure 18 and one of the red diamonds shown in Figure 19 indicate that the SRS 2H-Evaporator solutions were saturated with respect to the mixed zeolite at the evaporator temperature.

The sodium diuranate activity diagrams at $25^{\circ} \mathrm{C}$ (measurement temperature), $40^{\circ} \mathrm{C}$ (tank temperature), and $120^{\circ} \mathrm{C}$ (evaporator operating temperature) are shown in Figure 20 to Figure 25. The SRS 2H-Evaporator solutions were historically supersaturated with respect to $\mathrm{Na}_{2} \mathrm{U}_{2} \mathrm{O}_{7}$ at all temperatures modeled and continued to be supersaturated throughout the operating history of the newest SRS 2H-Evaporator pot. This was confirmed by the work of Hobbs and Karraker ${ }^{35}$, who found that fine $\mathrm{Na}_{2} \mathrm{U}_{2} \mathrm{O}_{7}$ crystalline particles persisted in all the simulated evaporator solutions they tested. This is also confirmed historically by observations of fine $\mathrm{Na}_{2} \mathrm{U}_{2} \mathrm{O}_{7}$ particulates in the evaporator drop tank samples. ${ }^{70}$ The equilibrium boundaries shown in Figure 20 to Figure 25 were calculated from the data in Table IV and Table $\mathrm{V}$ for the moderate silica low alumina operating period. The phase boundaries representing the equilibria between solid $\mathrm{Na}_{2} \mathrm{U}_{2} \mathrm{O}_{7}$ and solid Schoepite $\left(\mathrm{UO}_{3} \bullet 2 \mathrm{H}_{2} \mathrm{O}\right)$, solid $\mathrm{Na}_{2} \mathrm{U}_{2} \mathrm{O}_{7}$ and aqueous $\mathrm{NaCO}_{3}{ }^{-}$, and solid $\mathrm{Na}_{2} \mathrm{U}_{2} \mathrm{O}_{7}$ and aqueous $\mathrm{NaOH}$ are represented by the following equations:

\# To generate these plots, $\mathrm{Na}_{2} \mathrm{U}_{2} \mathrm{O}_{7}$ was swapped for the basis species $\mathrm{U}^{4+}$ in the GWB software, $\mathrm{CO}_{2}(\mathrm{aq})$ was swapped for the basis species $\mathrm{HCO}_{3}^{-}$, and $\mathrm{UO}_{2}^{++} / \mathrm{H}^{+}$was swapped for the basis species $\mathrm{H}^{+}$, and the activities of $\mathrm{Na}^{+}, \mathrm{NO}_{3}{ }^{-}, \mathrm{SiO}_{2}$ and $\mathrm{Al}(\mathrm{OH})_{4}^{-}$calculated for each tank composition in REACT were specified. This means that Equations 20-22 are balanced on $\mathrm{Na}_{2} \mathrm{U}_{2} \mathrm{O}_{7}$ instead of $\mathrm{U}^{4+}$, on $\mathrm{CO}_{2}(\mathrm{aq})$ instead of $\mathrm{HCO}_{3}$, and $\mathrm{UO}_{2}^{++} / \mathrm{H}^{+}$instead of $\mathrm{H}^{+}$. The activity diagrams were confined to minerals and aqueous species containing $\mathrm{Na}, \mathrm{U}, \mathrm{OH}$ and $\mathrm{CO}_{3}$ since these were the species of concern and the most prevalent species other than $\mathrm{Al}(\mathrm{OH})_{4}{ }^{-}$which does not participate in the formation of the uranate species. The redox state of the system during modeling is controlled by either an uncoupling command or by swapping $\mathrm{O}_{2}$ (gas) for $\mathrm{O}_{2}$ (aqueous) and setting the $\mathrm{O}_{2}$ (gas) fugacity at that of air, e.g. $0.21 \mathrm{~atm}$. 


$$
\begin{gathered}
\text { 4Schoepite }+2 \mathrm{Na}^{+} \Leftrightarrow \mathrm{Na}_{2} \mathrm{U}_{2} \mathrm{O}_{7}(\mathrm{c})+9 \mathrm{H}_{2} \mathrm{O}+2 \frac{\mathrm{UO}_{2}^{2+}}{\mathrm{H}^{+}} \\
2 \mathrm{NaCO}_{3}^{-}+\mathrm{H}_{2} \mathrm{O}+2 \frac{\mathrm{UO}_{2}^{2+}}{\mathrm{H}^{+}} \Leftrightarrow \mathrm{Na}_{2} \mathrm{U}_{2} \mathrm{O}_{7}(\mathrm{c})+2 \mathrm{CO}_{2}(\mathrm{aq}) \\
4 \mathrm{NaOH}+2 \frac{\mathrm{UO}_{2}^{2+}}{\mathrm{H}^{+}} \Leftrightarrow \mathrm{Na}_{2} \mathrm{U}_{2} \mathrm{O}_{7}(\mathrm{c})+\mathrm{H}_{2} \mathrm{O}+2 \mathrm{Na}^{+}
\end{gathered}
$$




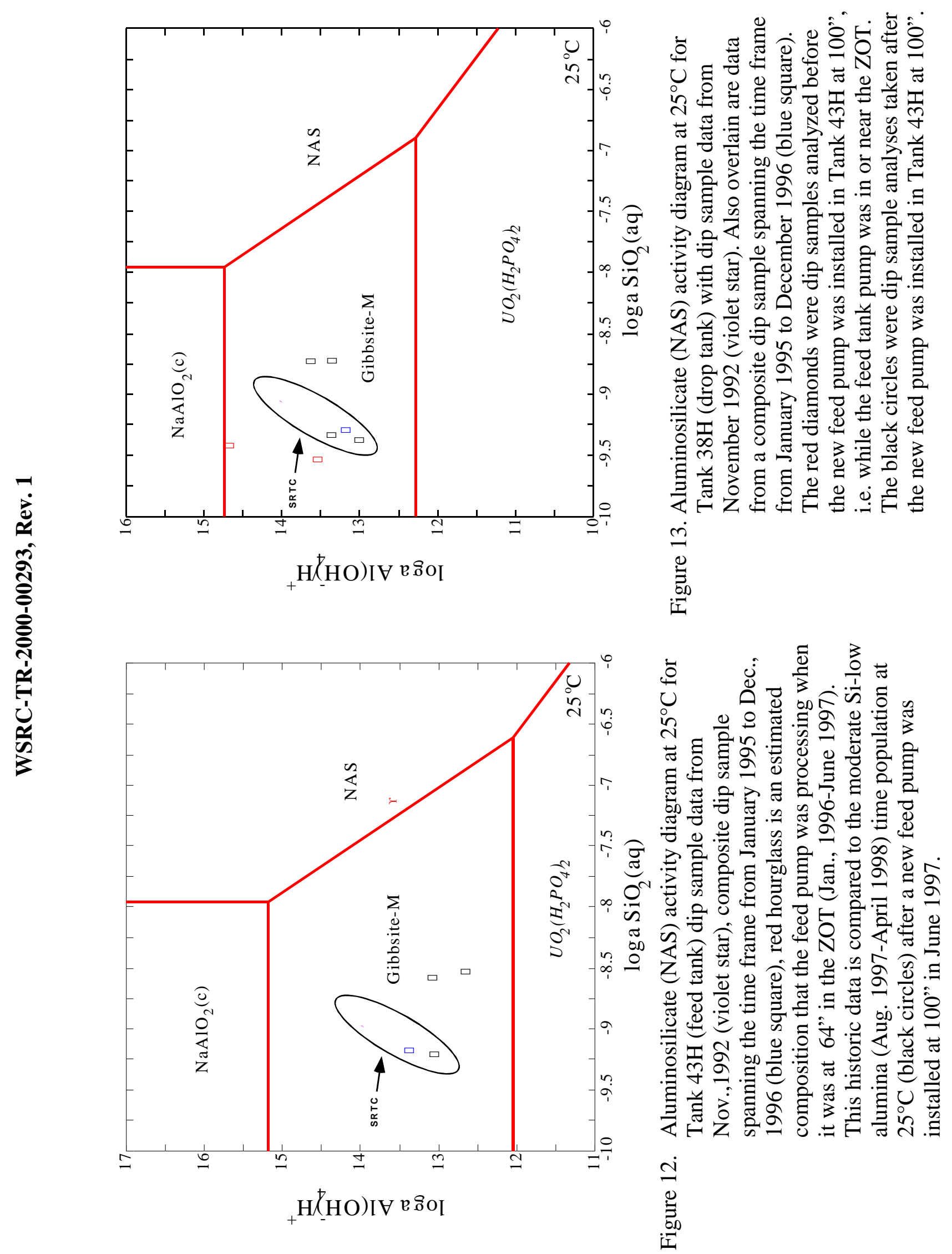



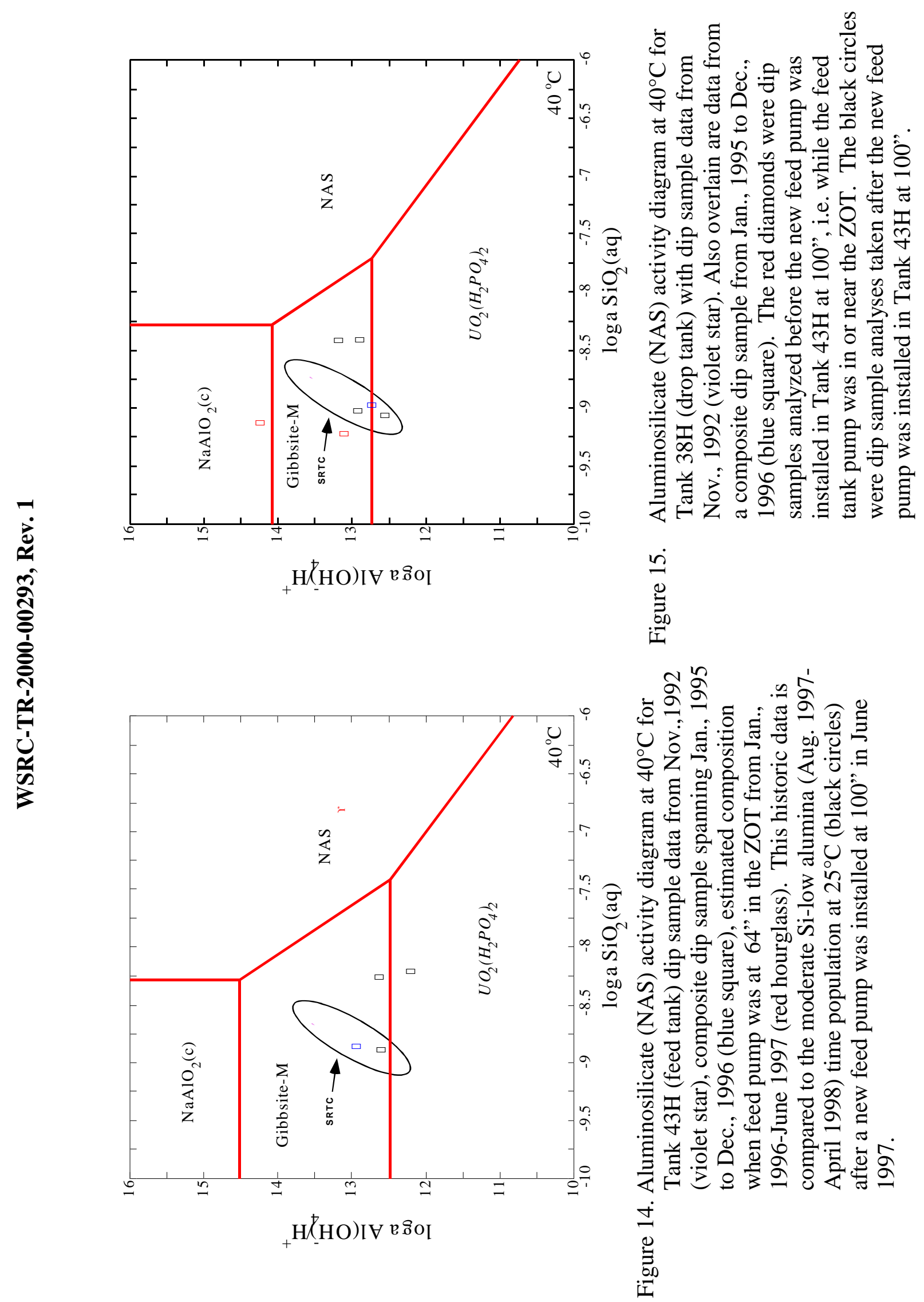


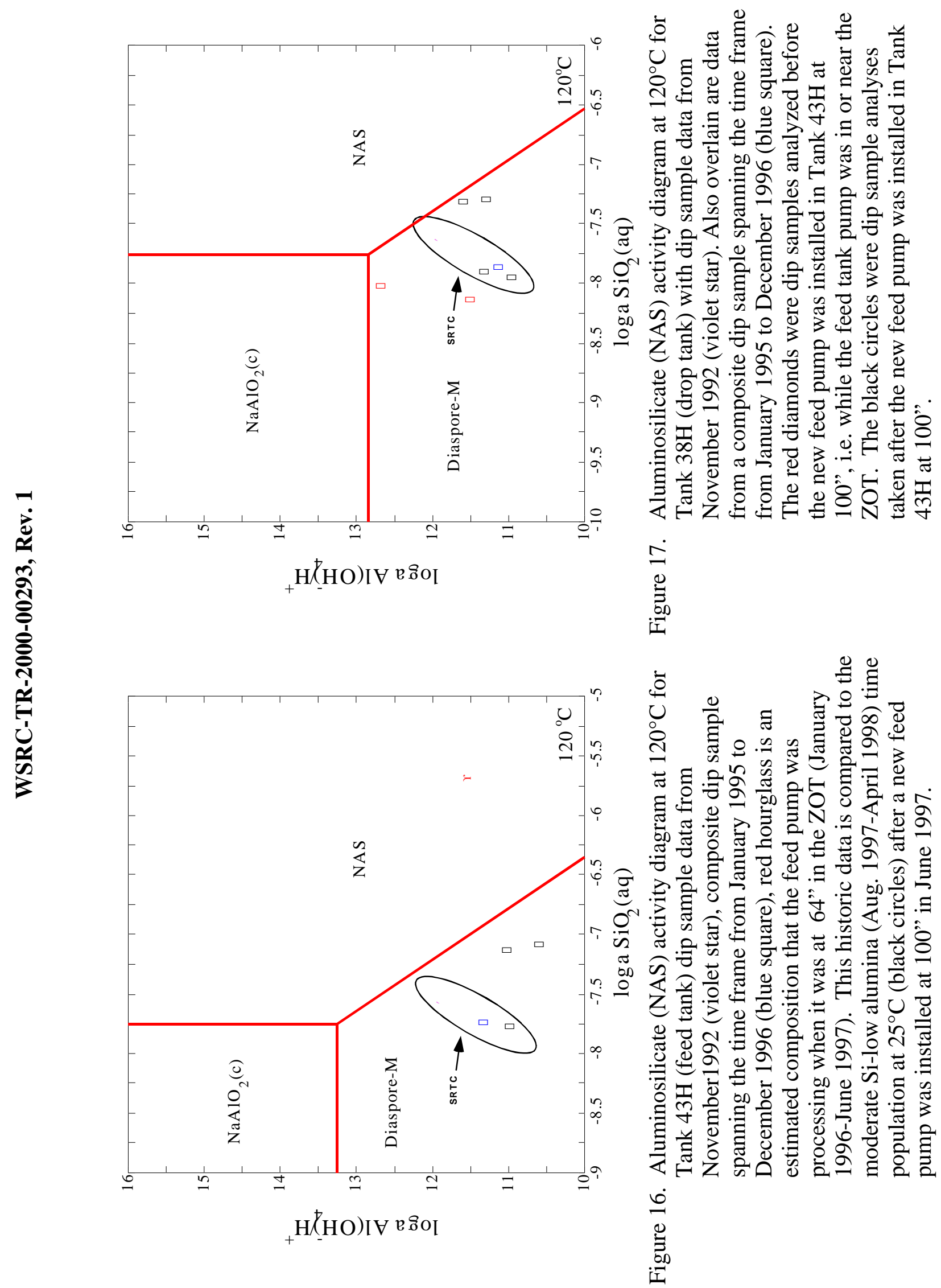




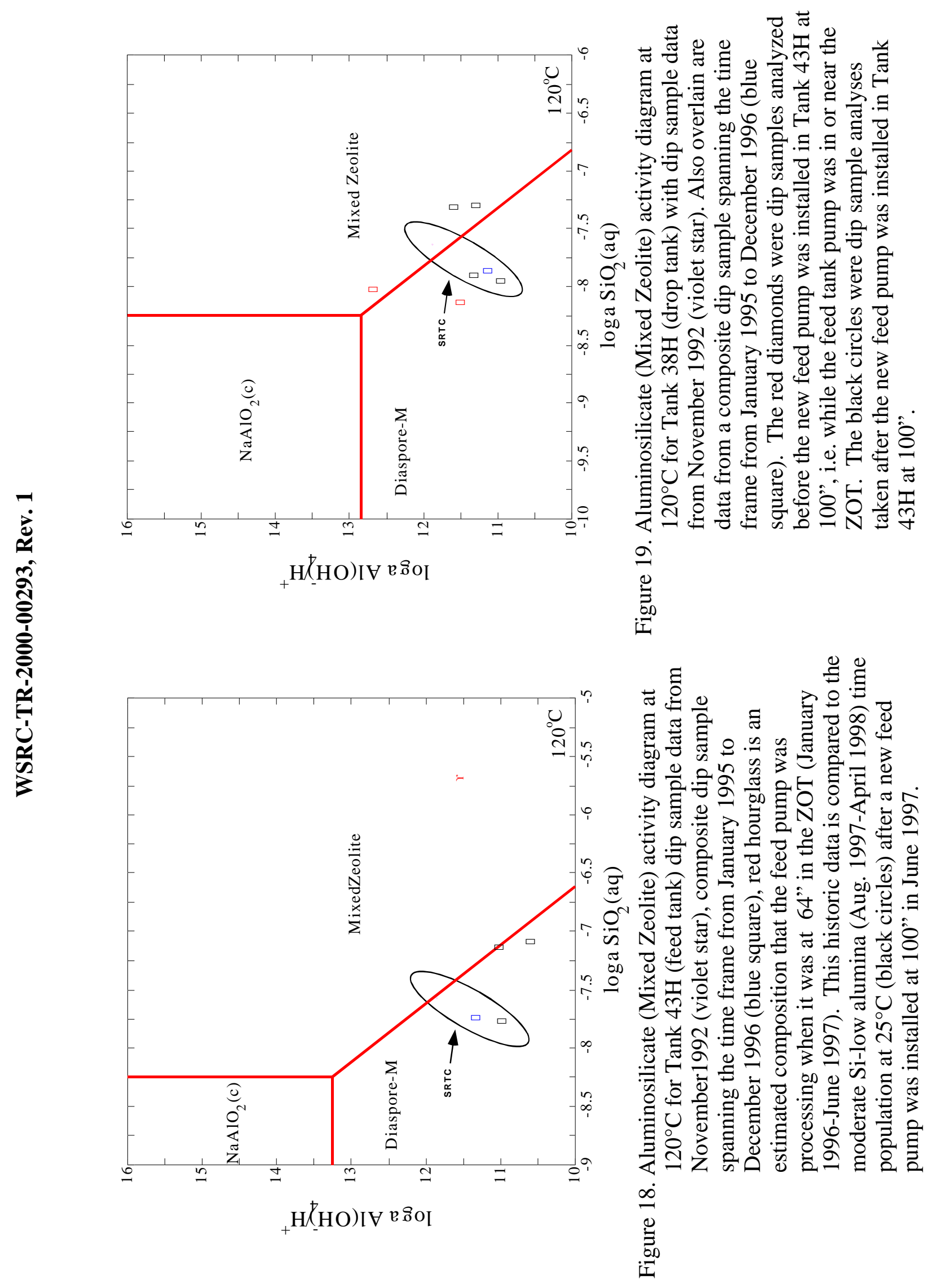



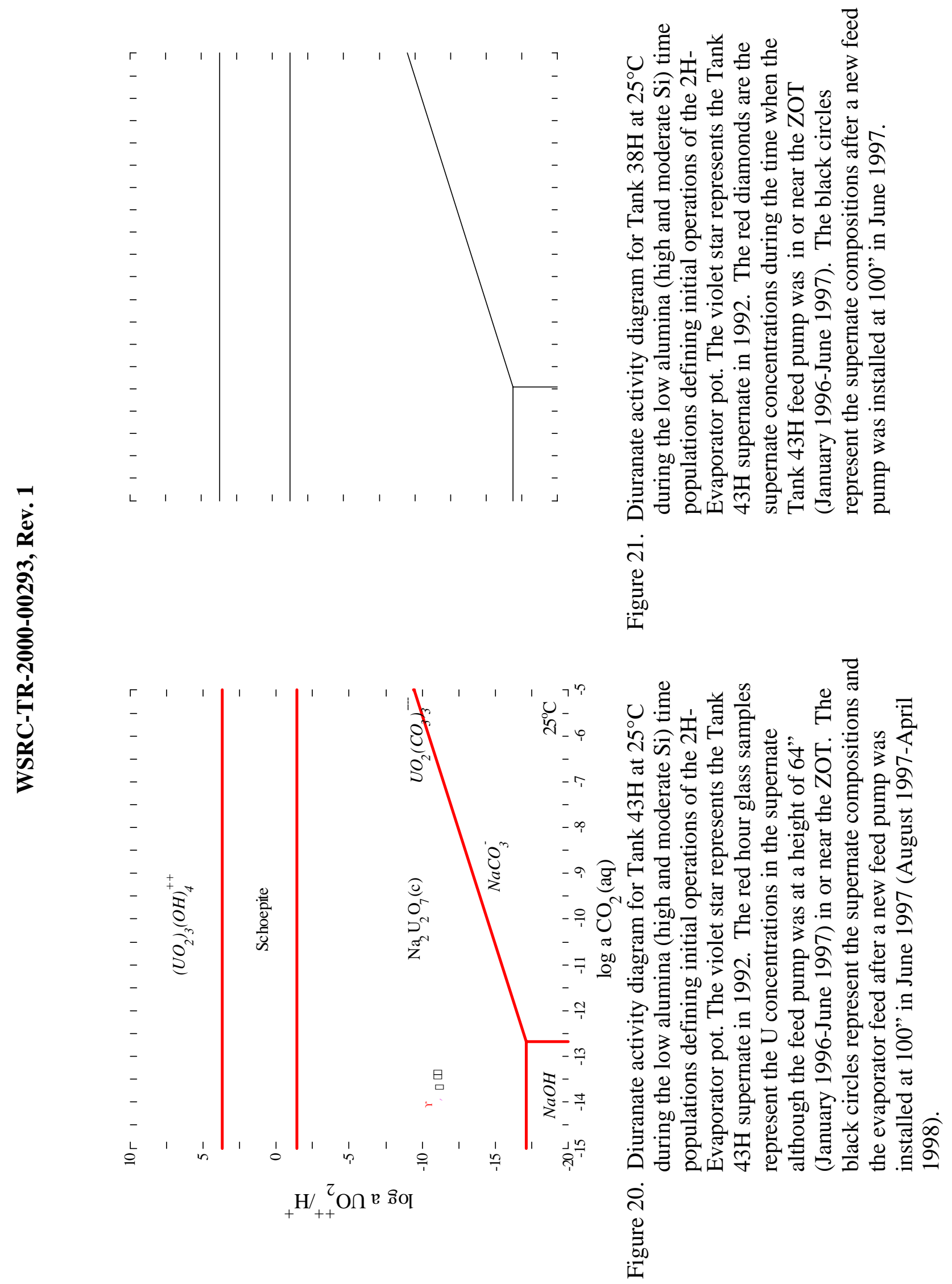

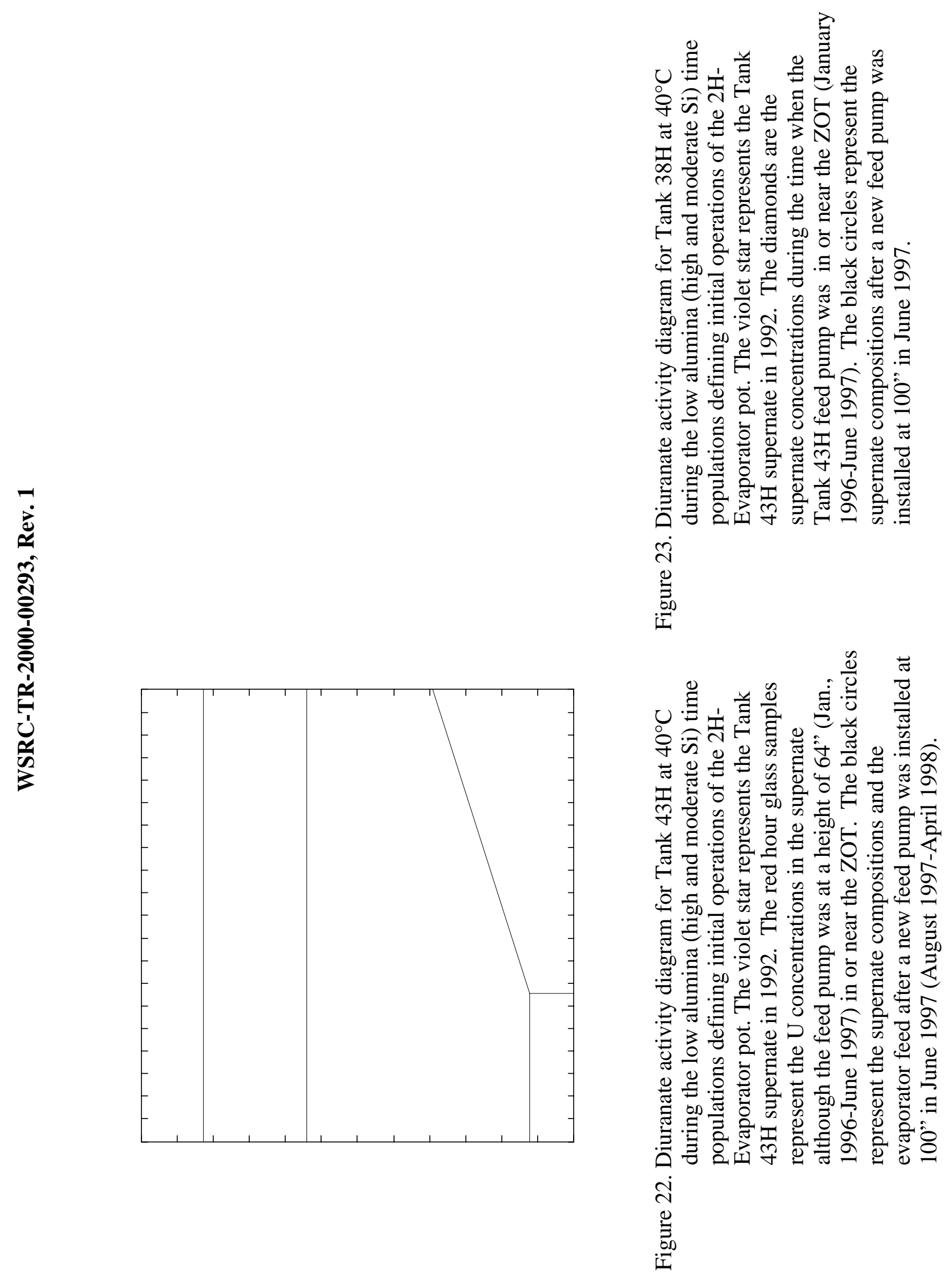

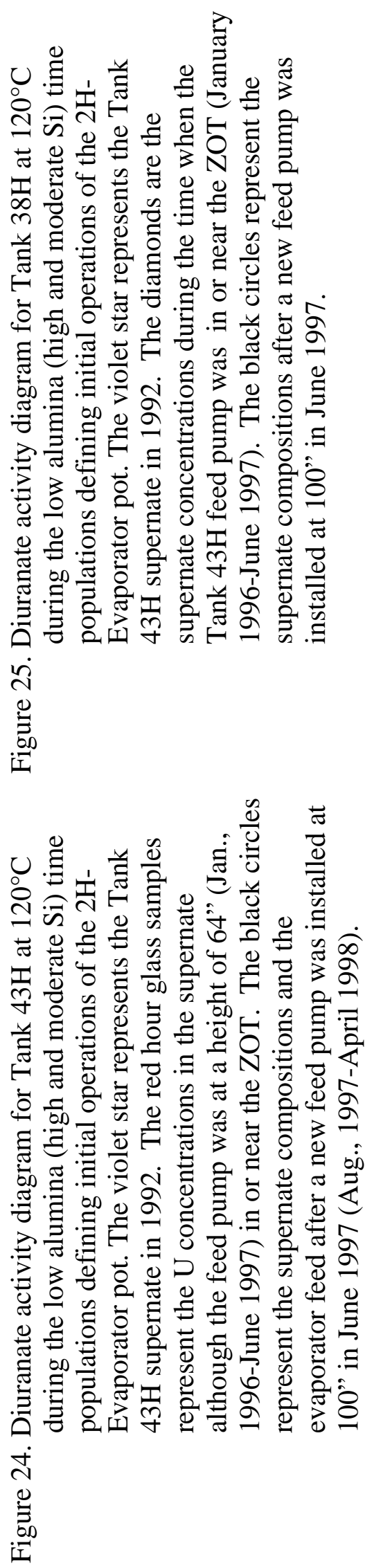


\section{WSRC-TR-2000-00293, Rev. 1}

\subsection{Higher Aluminum Operations}

The higher aluminum operations of the new SRS 2H-Evaporator pot are divided into two time populations, the "moderate Al, moderate Si" and the "high Al, moderate Si" time periods, delineated in Table VIII. These two time periods span the "higher Al" operations and will be compared to the "low Al" operations in Section 6.1.1. During the higher Al, time regimes the recently started DWPF gained control of the frequent SME carryovers but $\mathrm{H}$-canyon began to send high concentrations of $\mathrm{Al}$ rich solutions to Tank $43 \mathrm{H}$ (Figure 4 and Figure 8). Operations were only satisfactory for 2 months after the Al rich solutions began to be fed to Tank $43 \mathrm{H}$ (Table III).

The phase boundaries plotted in Figure 26, Figure 28, Figure 30, and Figure 32, represent the feed tank (Tank 43H) average concentrations for the high Al time regime spanning between November 1998 and August 1999 (Table IV). In order to perform a direct comparison of the feed tank and drop tank chemistries, the same time regime was used to calculate the phase boundaries for the drop tank (Tank 38H) in Figure 27, Figure 29, Figure 31, and Figure 33 . At $25^{\circ} \mathrm{C}$ and $40^{\circ} \mathrm{C}$ the equations governing the equilibrium between gibbsite and $\mathrm{NaAlO}_{2}$ are the same as those given in Equations 12-16.

Dip sample data from Tanks 43 and 38 analyzed by SRTC and F-area are overlain on Figure 27 to Figure 33. Dip sample data are shown for the moderate alumina time population, the high alumina time population, and the tank chemistry measured since the SRS 2H-Evaporator was shut down. Variable depth data measured by SRTC are also shown from February 2000 taken during the shutdown of the evaporator for Tank 43H. The majority of the silica data available for modeling the SRS 2H-Evaporator was from the F-Area laboratory and represents a worst case scenario since these analyses were

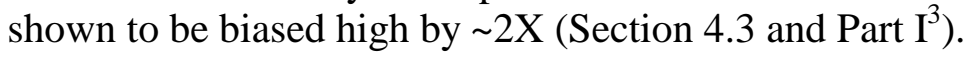

The dip sample data for Tank $43 \mathrm{H}$, the feed tank, from the moderate Al time population (March 1998 to November 1998) are plotted in Figure 26 at the sample measurement temperature of $25^{\circ} \mathrm{C}$. The data for Tank $38 \mathrm{H}$ are shown in Figure 27 for comparison at the same temperature. The moderate Al time population data are overlain and shown by the blue diamonds in both figures. During the moderate Al time population the feed and drop tanks were not supersaturated with respect to the NAS phase. The high alumina time populations are shown as black circles and span dip sample analyses from November 1998 to October 1999. Each dip sample point is labeled with a date in both figures. If the samples are examined in numerical order by date, it can be seen that the November 1998 samples in the feed tank and drop tank are not saturated with respect to the NAS phase. However, the March 1999 sample indicates that the feed tank is not saturated with respect to the NAS phase but the drop tank is. By June 1999 and August 1999 both tanks were supersaturated with respect to the NAS phase.

Activity diagrams were generated at the nominal temperature $\left(40^{\circ} \mathrm{C}\right)$ of the SRS $2 \mathrm{H}$ Evaporator feed and drop tanks using the polythermal reaction option in GWB. The Tank $43 \mathrm{H}$ and Tank $38 \mathrm{H}$ dip sample data in Figure 28 and Figure 29 at $40^{\circ} \mathrm{C}$ show the same 


\section{WSRC-TR-2000-00293, Rev. 1}

trends for the moderate and high alumina time populations as Figure 26 and Figure 27 at $25^{\circ} \mathrm{C}$.

Activity diagrams were generated at the elevated temperature $\left(120^{\circ} \mathrm{C}\right)$ of the SRS $2 \mathrm{H}-$ Evaporator using the polythermal reaction option in GWB. The effects of elevated temperature on the relative phase stability fields are examined for solutions at a specific gravity of $\sim 1.45 \mathrm{~g} / \mathrm{cc}$, the nominal specific gravity achieved to in the $2 \mathrm{H}$-Evaporator. The effects of an additional evaporation of $40 \%$ that would yield evaporator solutions of $\sim 1.6$ specific gravity are not considered since the SRS $2 \mathrm{H}$-Evaporator never achieved these solution densities.

At the elevated temperature of $120^{\circ} \mathrm{C}$, the gibbsite phase, $\mathrm{Al}(\mathrm{OH})_{3}$ is no longer stable as discussed in Section 6.1.1 and the mineral diaspore $(\mathrm{AlOOH})$ is the stable alumina phase. The phase boundaries plotted in Figure 30-Figure 33 represent the feed tank (Tank 43H) average concentrations for the same high $\mathrm{Al}$ time regime used to generate the activity diagrams at $25^{\circ} \mathrm{C}$ and $40^{\circ} \mathrm{C}$. The pertinent equilibria between diaspore and NAS, $\mathrm{NaAlO}_{2}$, and $\mathrm{UO}_{2}\left(\mathrm{H}_{2} \mathrm{PO}_{4}\right)_{2}$ are given in Equations 17-19.

As stated previously, Ejaz. ${ }^{22}$ has suggested that the NAS phase may not be the stable phase at elevated temperature due to the rapid kinetics of the NAS transformation into Zeolite-A and other phases. A mixture of Zeolite-A and hydroxysodalite, such as that observed by Gasteiger et. al. ${ }^{17}$ at $95^{\circ} \mathrm{C}$ in evaporators in the paper and pulp industry, is more likely at $120^{\circ} \mathrm{C}$. Therefore, the activity diagrams for the SRS $2 \mathrm{H}$-Evaporator feed tank and the drop tank showing the equilibrium with $\mathrm{NAS}_{\text {gel }}$ are presented in Figure 30 and Figure 31 while the activity diagrams showing the equilibrium with the Gasteiger mixed zeolite are shown in Figure 32 and Figure 33. It should be noted that the solubility data of $\mathrm{Ejaz}^{22}$ for the $\mathrm{NAS}_{\mathrm{gel}}$ and the solubility data of Gasteiger ${ }^{17}$ are very similar and confirmatory of each other. However, each of these diagrams is based on solubility extrapolations as discussed in Appendix B.

At the elevated temperature of the SRS 2H-Evaporator the dip sample data taken during the moderate alumina processing time period (Figure 30 and Figure 31) as indicated by blue diamonds show that the evaporator tank solutions were not saturated with respect to the $\mathrm{NAS}_{\mathrm{gel}}$ phase. As the alumina content continued to increase, (see the black circles), the SRS 2H-Evaporator solutions became saturated with respect to the NAS phase.

Surprisingly, a comparison of the dip sample data (green stars) taken for the SRS $2 \mathrm{H}$ Evaporator feed tank at $120^{\circ} \mathrm{C}$ (Figure 30) to the drop tank data (Figure 31) for the time period after the evaporator was shut down indicates that the feed tank is no longer supersaturated with respect to the NAS phase but the drop tank is supersaturated with respect to the NAS phase. This is confirmed by the recent VDS sample taken at 100" above the tank bottom which is also not saturated with respect to the NAS phase. This indicates that the evaporator drop tank was more supersaturated than the feed tank.

Conversely, when the mixed zeolite phase is modeled at the elevated temperature of the SRS 2H-Evaporator the dip sample data taken during the moderate alumina processing time period (Figure 32 and Figure 33) indicated by the blue diamonds, shows that the 62 


\section{WSRC-TR-2000-00293, Rev. 1}

evaporator tank solutions were just saturated with respect to the mixed zeolite phase based on the Si analyses from the F-Area Laboratory. Given that the GDL plugged for the second time and deposits were observed in the evaporator pot within two months of the initiation of the moderate alumina processing (Table III) it is likely that the evaporator feed and drop tank solutions were supersaturated with respect to the mixed zeolite. The more alumina enriched the SRS 2H-Evaporator system became (see Figure 8), the more supersaturated the solutions became with respect to the mixed zeolite as indicated by the black circles in Figure 32 and Figure 33.

The dip sample data (green stars) taken for the SRS $2 \mathrm{H}$-Evaporator feed tank at $120^{\circ} \mathrm{C}$ (Figure 32) to the drop tank data (Figure 33) for the time period after the evaporator was shut down indicates that the feed tank is no longer supersaturated with respect to the mixed zeolite phase similar to the $120^{\circ} \mathrm{C}$ modeling of the NAS phase shown in Figure 30 . However, the drop tank is supersaturated with respect to the mixed zeolite phase similar to the $120^{\circ} \mathrm{C}$ modeling of the NAS phase (compare Figure 31 to Figure 33). In addition, the 100" VDS sample in the feed tank is just saturated with respect to the mixed zeolite phase (Figure 32).

The sodium diuranate activity diagrams at $25^{\circ} \mathrm{C}$ (measurement temperature), $40^{\circ} \mathrm{C}$ (tank temperature), and $120^{\circ} \mathrm{C}$ (evaporator operating temperature) are shown in Figure 34 to Figure 39. The SRS 2H-Evaporator solutions have always been supersaturated with respect to $\mathrm{Na}_{2} \mathrm{U}_{2} \mathrm{O}_{7}$ at all temperatures modeled and continued to be supersaturated throughout the operating history of the newest SRS 2H-Evaporator pot. This was confirmed by the work of Hobbs and Karraker ${ }^{35}$, who found that fine $\mathrm{Na}_{2} \mathrm{U}_{2} \mathrm{O}_{7}$ crystalline particles persisted in all the simulated evaporator solutions they tested. This is also confirmed historically by observations of fine $\mathrm{Na}_{2} \mathrm{U}_{2} \mathrm{O}_{7}$ particulates in the reactor drop tank samples. ${ }^{70}$ The equilibrium boundaries shown in Figure 34 to Figure 39 were calculated from the data in Table IV and Table $\mathrm{V}$ for the higher alumina operating period. The phase boundaries representing the equilibria between solid $\mathrm{Na}_{2} \mathrm{U}_{2} \mathrm{O}_{7}$ and solid Schoepite $\left(\mathrm{UO}_{3} \bullet 2 \mathrm{H}_{2} \mathrm{O}\right)$, solid $\mathrm{Na}_{2} \mathrm{U}_{2} \mathrm{O}_{7}$ and aqueous $\mathrm{NaCO}_{3}{ }^{-}$, and solid $\mathrm{Na}_{2} \mathrm{U}_{2} \mathrm{O}_{7}$ and aqueous $\mathrm{NaOH}$ are represented by the Equations 20-22. 


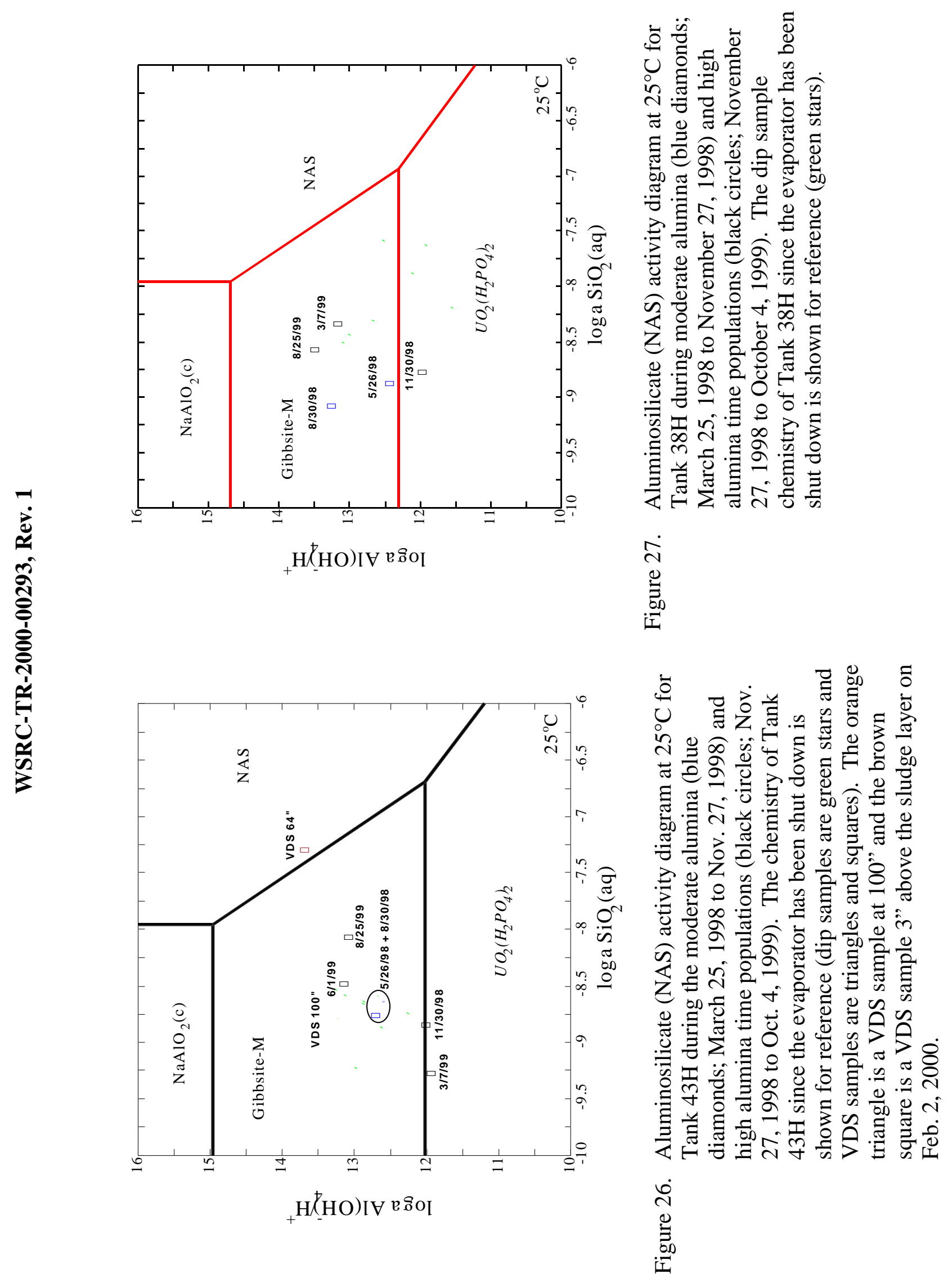




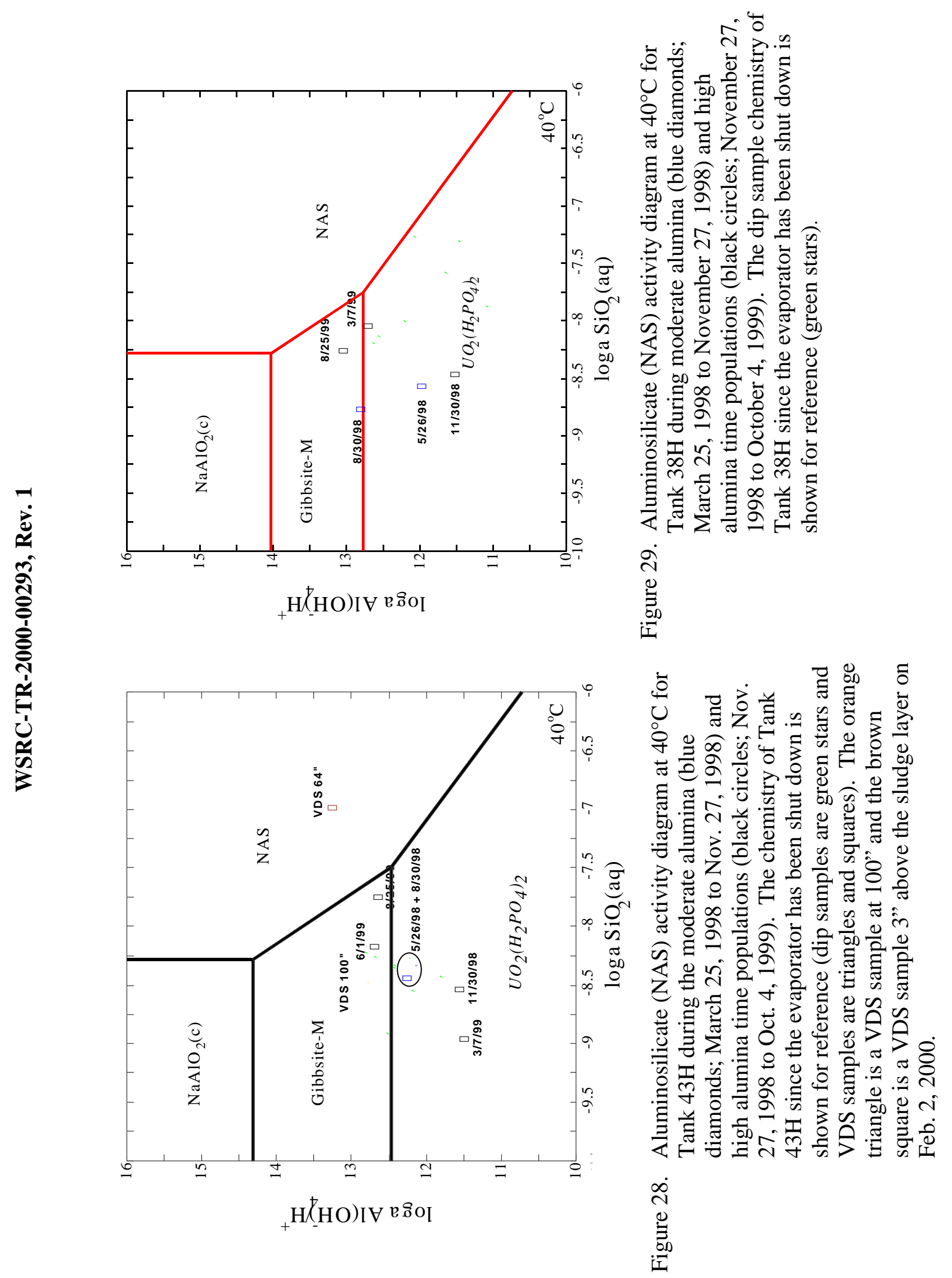




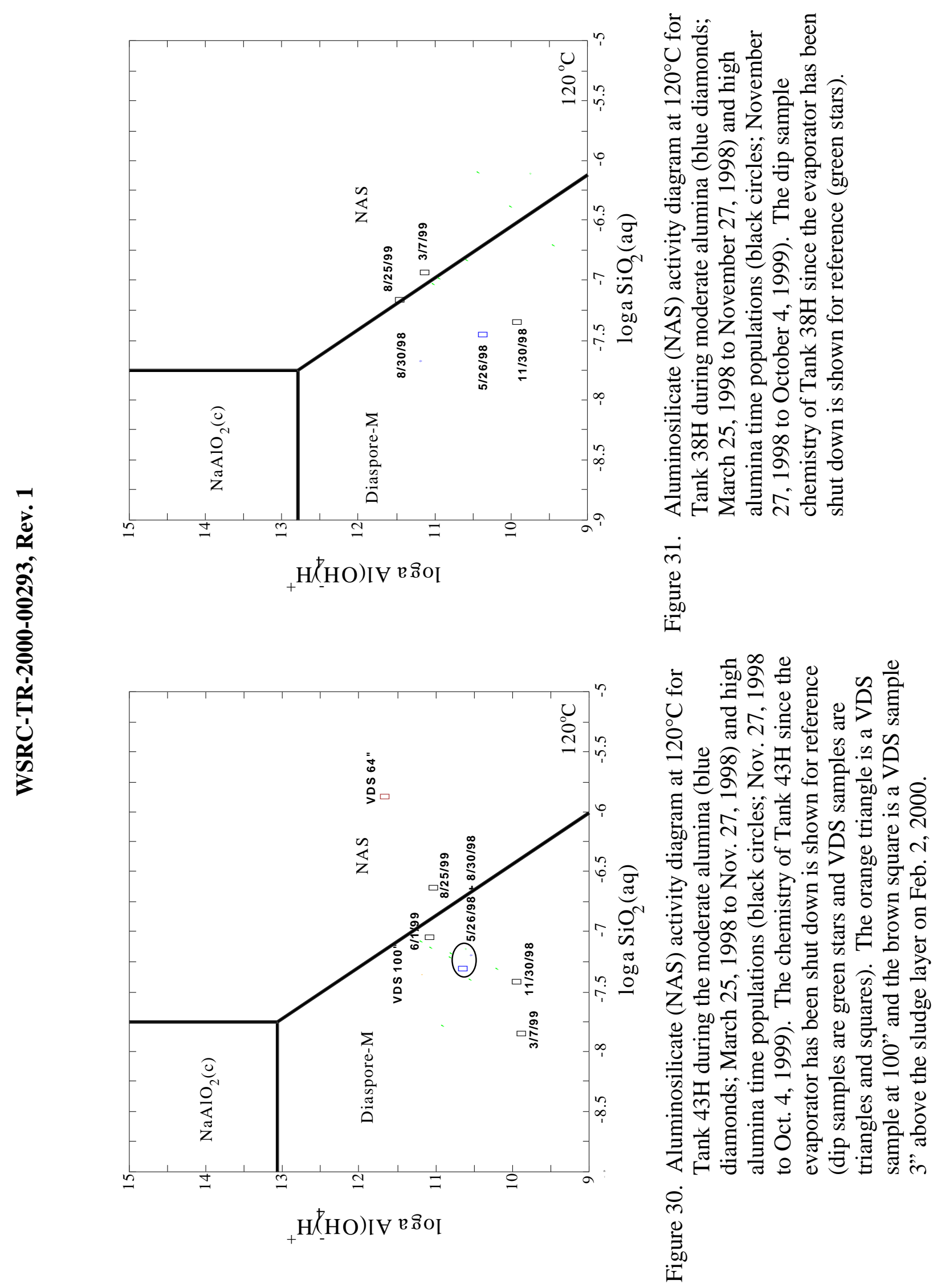



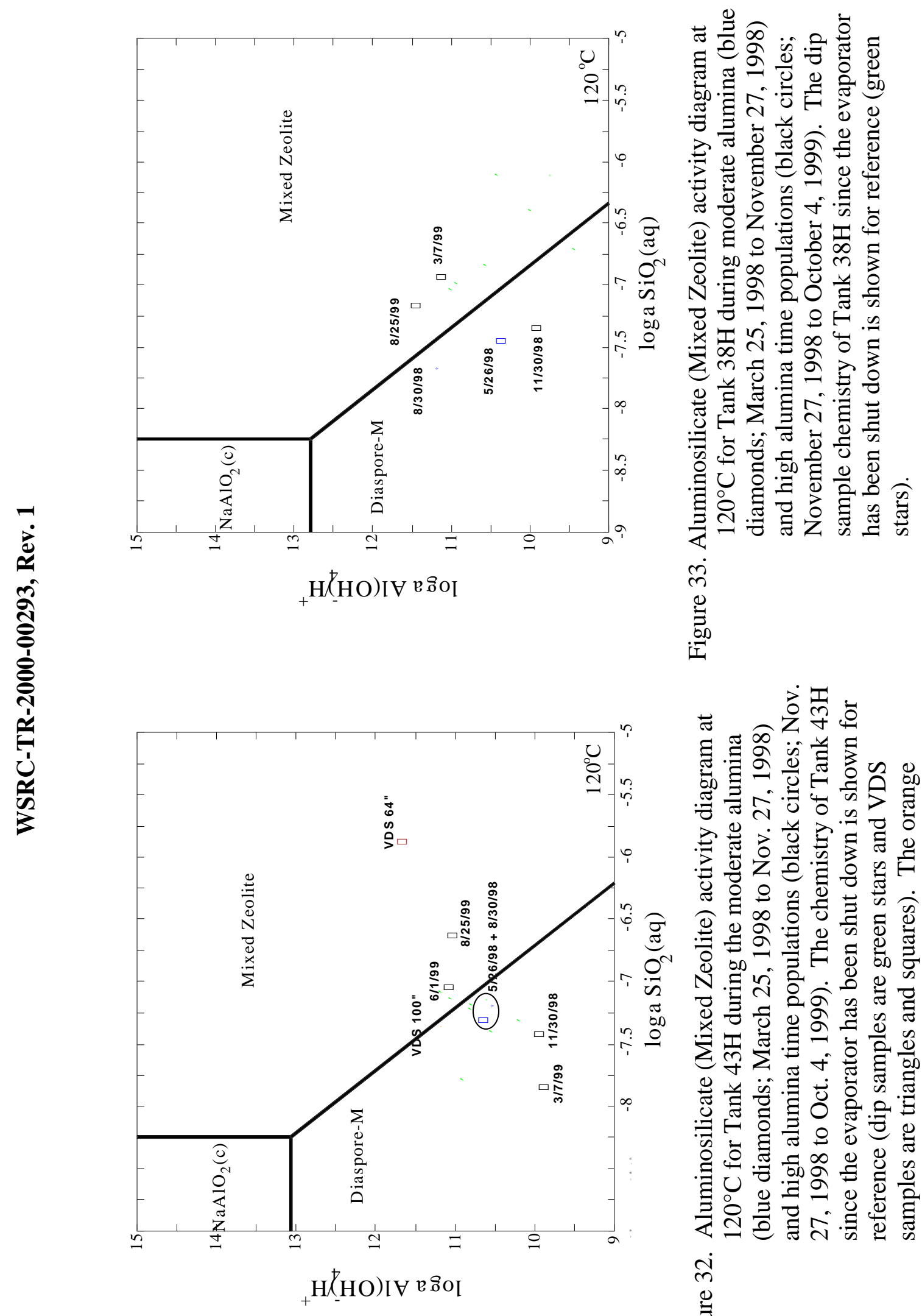

6

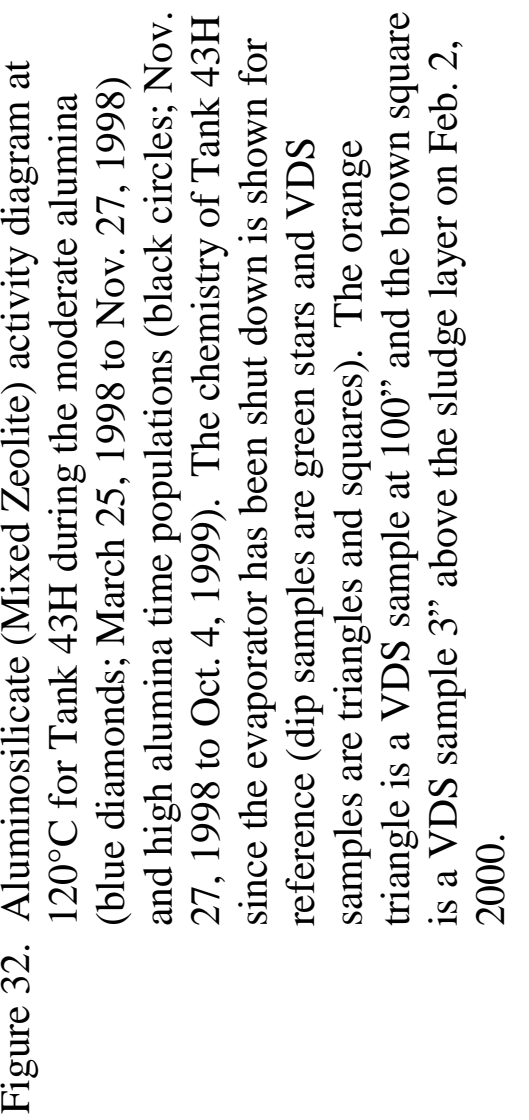




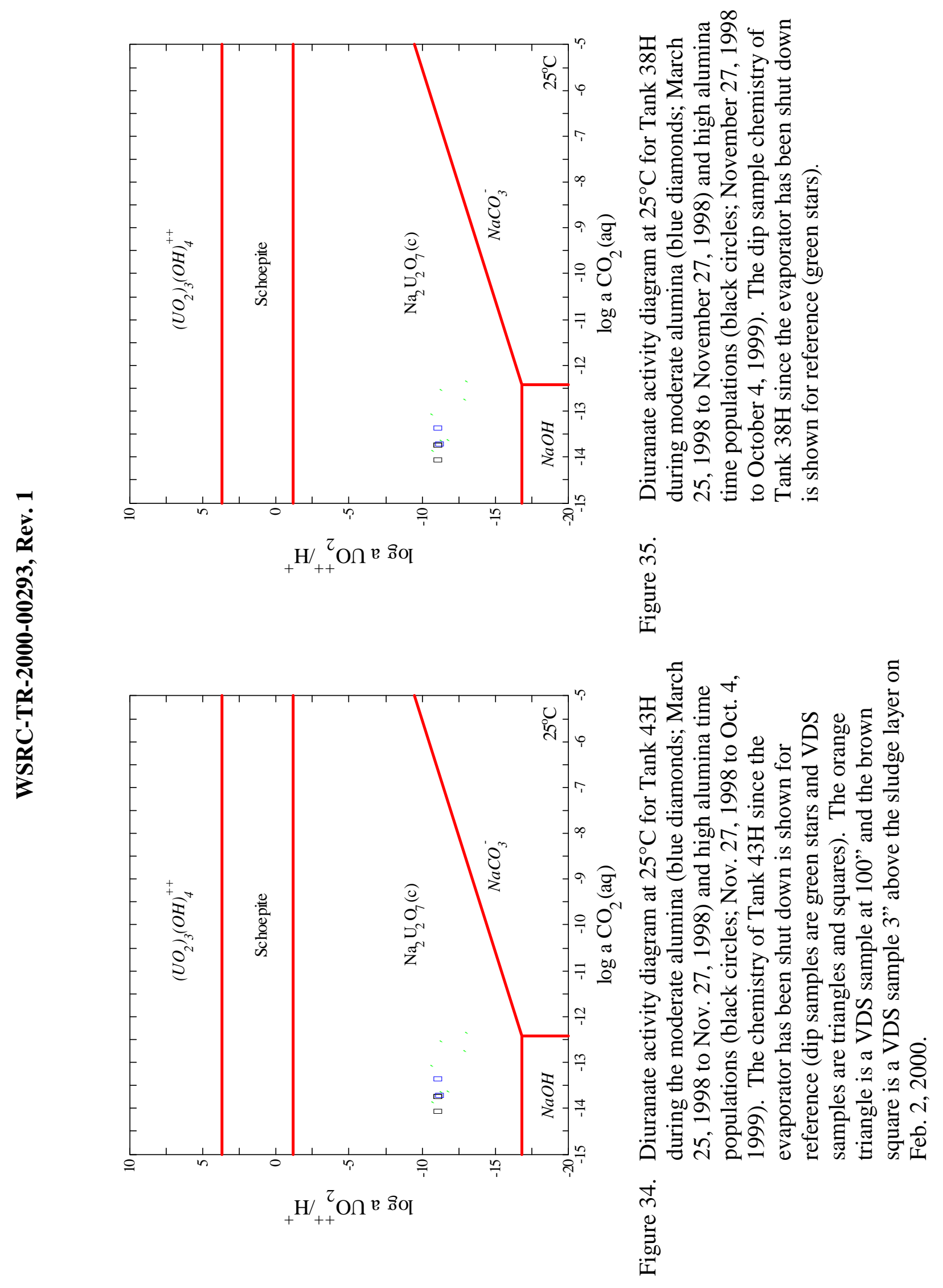




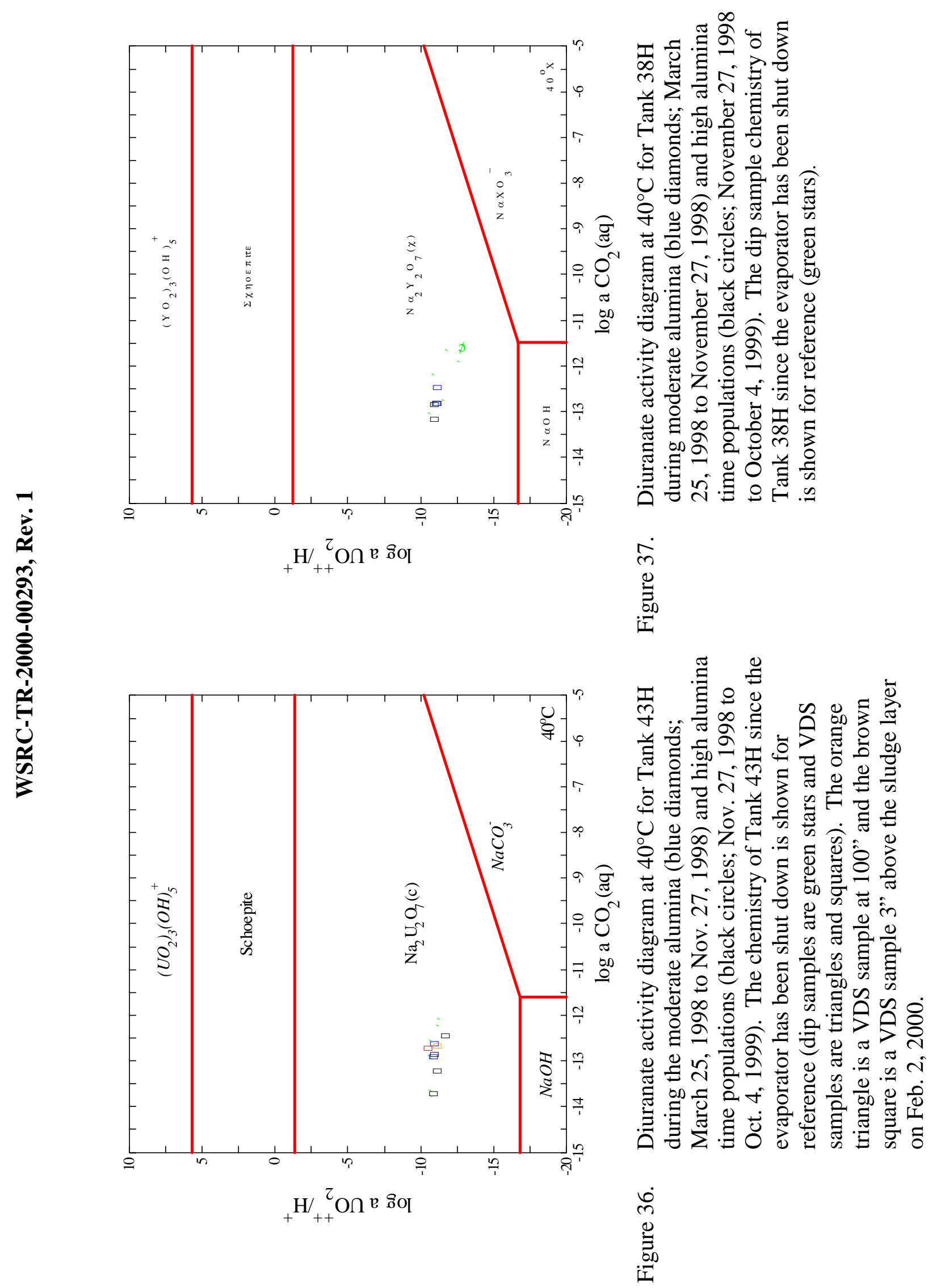




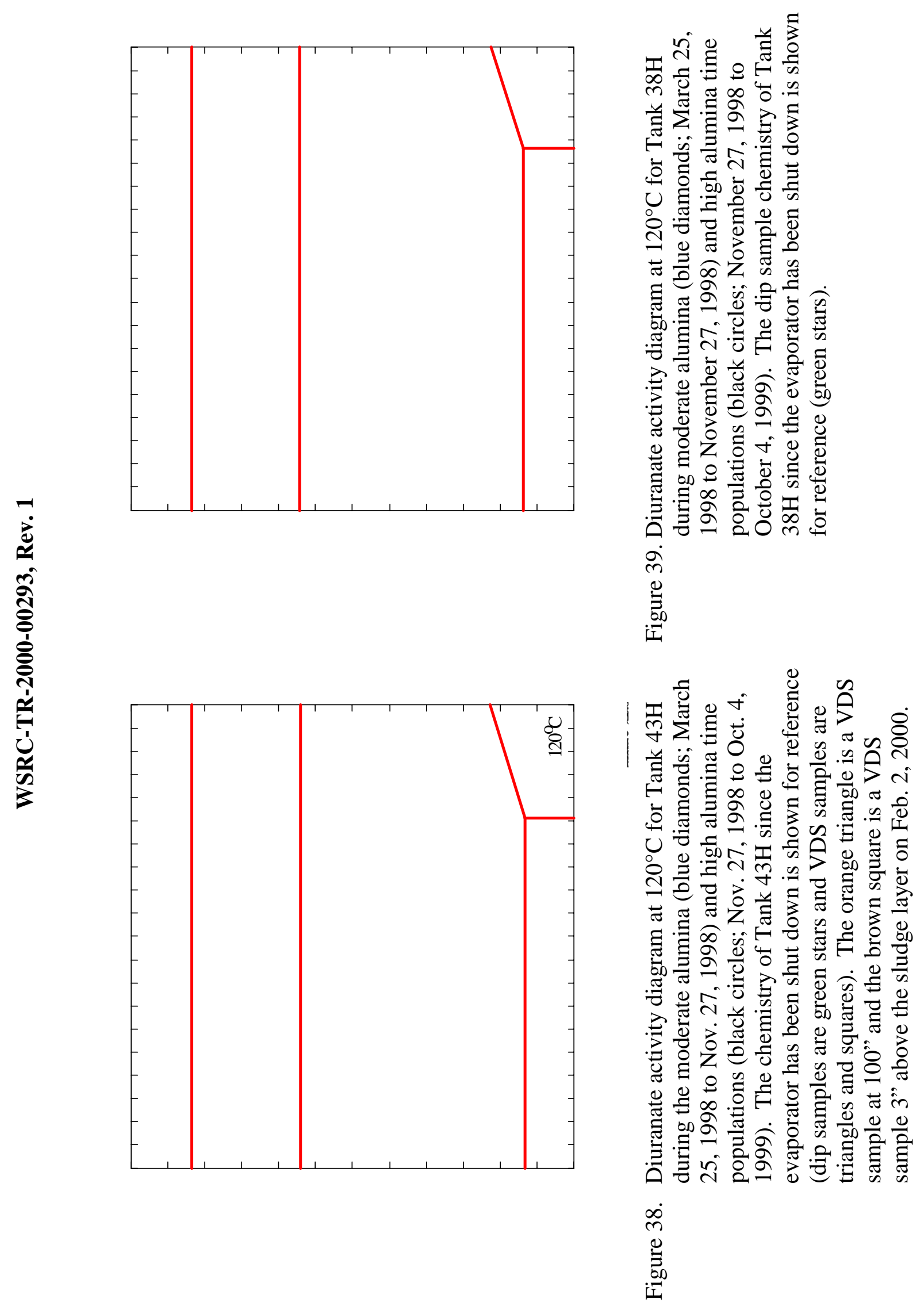


WSRC-TR-2000-00293, Rev. 1

This page intentionally left blank. 


\subsection{ACTIVITY DIAGRAM MODELING FOR THE SRS 2F-Evaporator}

\subsection{Operation Comparison Between the SRS 2F and 2H-Evaporators}

The SRS 2F-Evaporator, which has never had any difficulty with scaling and/or deposition of aluminosilicates, is of similar design to the SRS 2H-Evaporator. The SRS $2 \mathrm{~F}$-Evaporator feed tank is Tank $26 \mathrm{~F}$ and the drop tank is Tank $46 \mathrm{~F}$. The height of the sludge in Tank $26 \mathrm{~F}$ is $\sim 65$ " and the feed pump is at a height of 155 " from the bottom of the tank, a conservative 90" higher than the sludge layer and 70" higher than the ZOT. The height of the salt/sludge in Tank 46F is between 150-190" and the height of the transfer jet is $\sim 200$ " above the tank bottom. The transfer jet is, therefore, some 10-60" above the height of the salt surface in the drop tank. In addition, there are two settling tanks in front of Tank 26F, Tanks 33 and 34. Tank 33 is the tank that is currently used to accumulate fresh feed for Tank 26F. Tank 34 has not been actively used and would be considered "settled feed" if needed. The SRS 2F-Evaporator runs at $120^{\circ} \mathrm{C}$ like the SRS $2 \mathrm{H}$-Evaporator and recycles are made directly to Tank $26 \mathrm{~F}$ from Tank 46F. The SRS $2 \mathrm{~F}-$ Evaporator runs at a much higher free hydroxide content $\left(\mathrm{OH}^{-} \sim 9-10\right)$ vs. the SRS $2 \mathrm{H}-$ Evaporator $\left(\mathrm{OH}^{-} \sim 3-4\right)$.

Therefore, the SRS 2F and 2H-Evaporators have been operated differently as follows:

- the SRS 2F-Evaporator feed pump is a conservative 90" above the sludge layer vs. $\sim 47$ " in the SRS $2 \mathrm{H}$-Evaporator

- the SRS 2F-Evaporator feed pump is a conservative 70" above the ZOT vs. 27" in the SRS 2H-Evaporator

- the SRS 2F-Evaporator feed tank is fed fresh feed from a settling tank (Tank 33) while the SRS $2 \mathrm{H}$-Evaporator is directly fed from an active feed tank

- the SRS 2F-Evaporator transfer jet is 10-60" above the salt layer in the drop tank (Tank 46F) while the SRS 2H-Evaporator transfer jet is 10" below the salt layer

These differences in operation allow for more settling of any colloidal species and minimize the amount of colloidal species that can enter the SRS 2F-Evaporator.

\subsection{Availability and Quality of Analytic Data}

A compilation of molar chemical analyses for Tanks 26 and 46 appears in Table IX and Table X. There were sparse and incomplete data in the tank farm historic records. Specifically there were no Si analyses available for the feed tank (Tank 43H) and drop tank compositions between November 1992 and May 1997. Data for several cations were missing from the tank farm historic records and had to be estimated by averaging from other available historic tank data in the table. 


\section{WSRC-TR-2000-00293, Rev. 1}

The majority of the available data for Tanks 26 and 46 were analyzed by F-Area and only a few analyses measured by SRTC are available for these tanks. The SRTC analyses include a historic sample from 1992 for the feed tank (Tank 26F) and a 1995-1996 composite for both the feed tank (Tank 26F) and the drop tank (Tank 46F). One other SRTC analysis completed in 1999 is available for both the feed tank and the drop tank.

\subsection{Aluminosilicate Activity Diagrams}

The aluminosilicate activity diagrams for the SRS $2 \mathrm{~F}$-Evaporator at $25^{\circ} \mathrm{C} .40^{\circ} \mathrm{C}$, and $120^{\circ} \mathrm{C}$ are shown in Figure 40 to Figure 47 for the feed and drop tanks. The activity diagrams at the solution measurement temperature of $25^{\circ} \mathrm{C}$ (Figure 40 and Figure 41) and at the tank temperature of $40^{\circ} \mathrm{C}$ (Figure 42 and Figure 43) indicate that the feed and drop tanks are not supersaturated with respect to the $\mathrm{NAS}_{\text {gel }}$ phase. Figure 42 indicates that the SRS 2F-Evaporator system feeds were approximately the same Si content in 1992 (red triangle) than in the feeds in the 1995 to present.

At the evaporator operating temperature of $120^{\circ} \mathrm{C}$, only a few of the F-Area laboratory data points shown in Figure 44 and Figure 45 indicate that the SRS 2F-Evaporator system could be saturated with respect to the NAS $\mathrm{Sel}_{\text {gh }}$ phase. However, the F-Area laboratory data for Si has previously been shown to be biased high and should be discounted as the evaporator has not exhibited any aluminosilicate deposition. Likewise, many of the F-Area laboratory data points in Figure 46 and Figure 47 indicate that the SRS 2F-Evaporator could be saturated with respect to mixed zeolite while the SRTC analyses indicate that the system should not be saturated with respect to mixed zeolite. It is, therefore, the conclusion of this analysis that the SRS 2F-Evaporator system is not saturated with respect to either $\mathrm{NAS}_{\text {gel }}$ nor mixed zeolite at the operating temperature of $120^{\circ} \mathrm{C}$. 


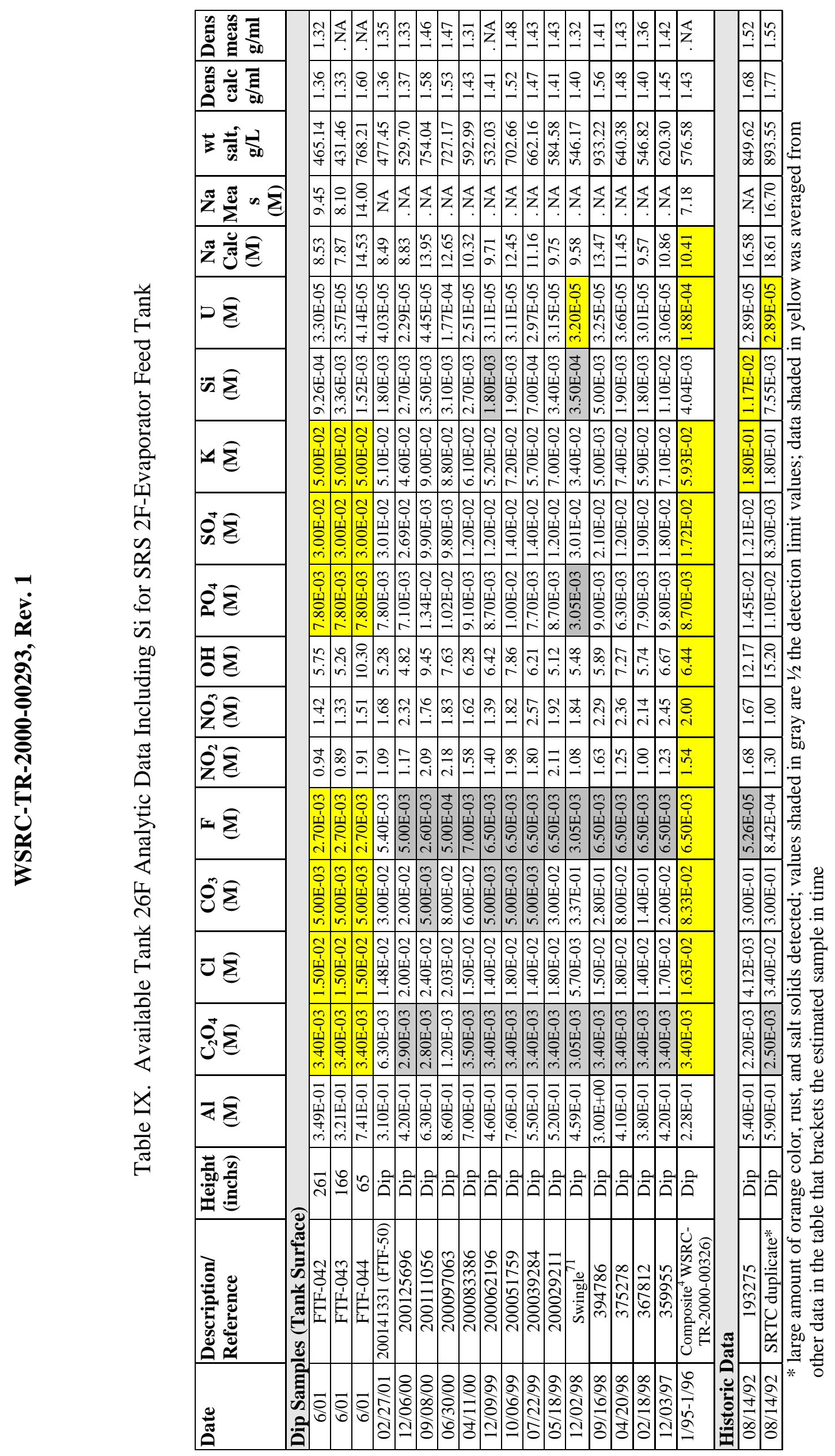




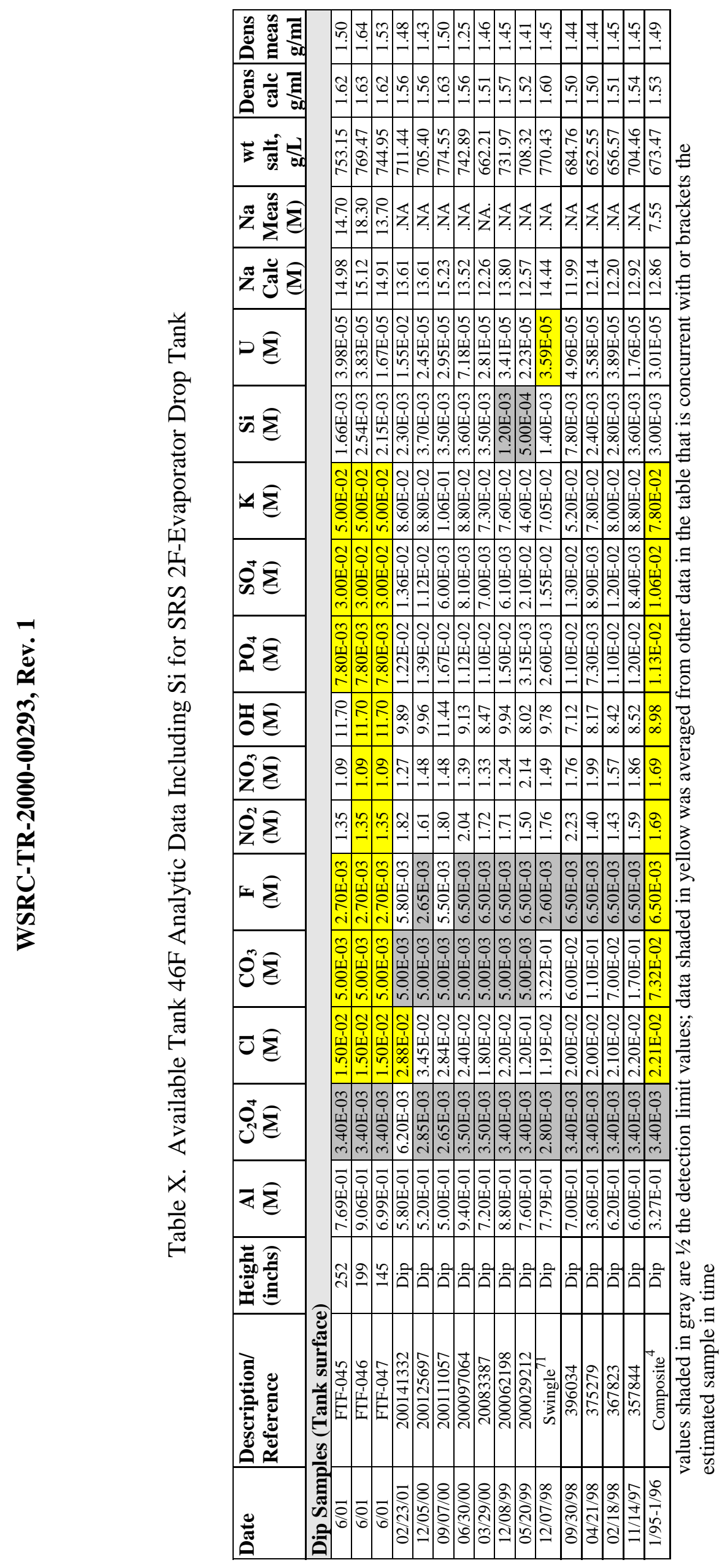




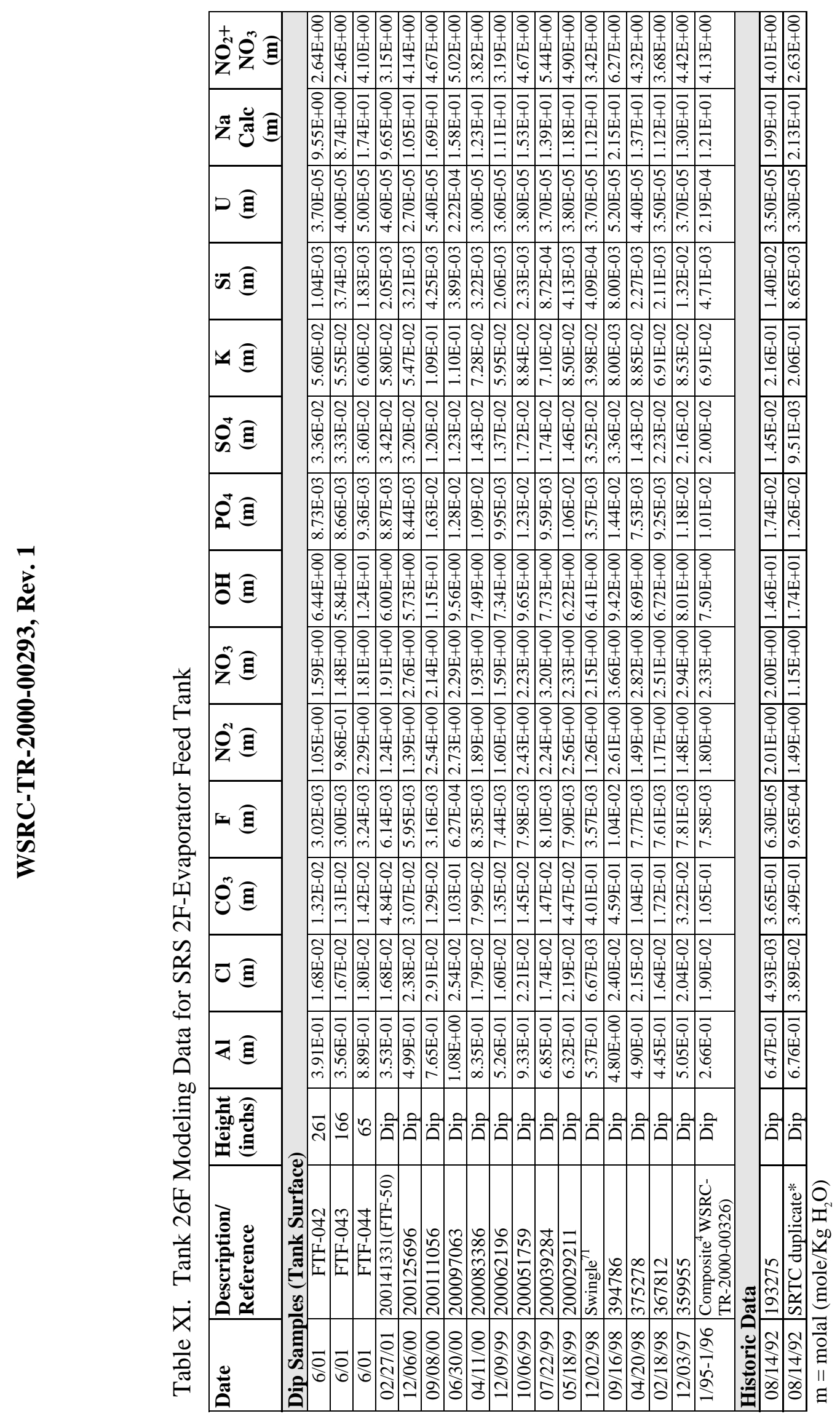




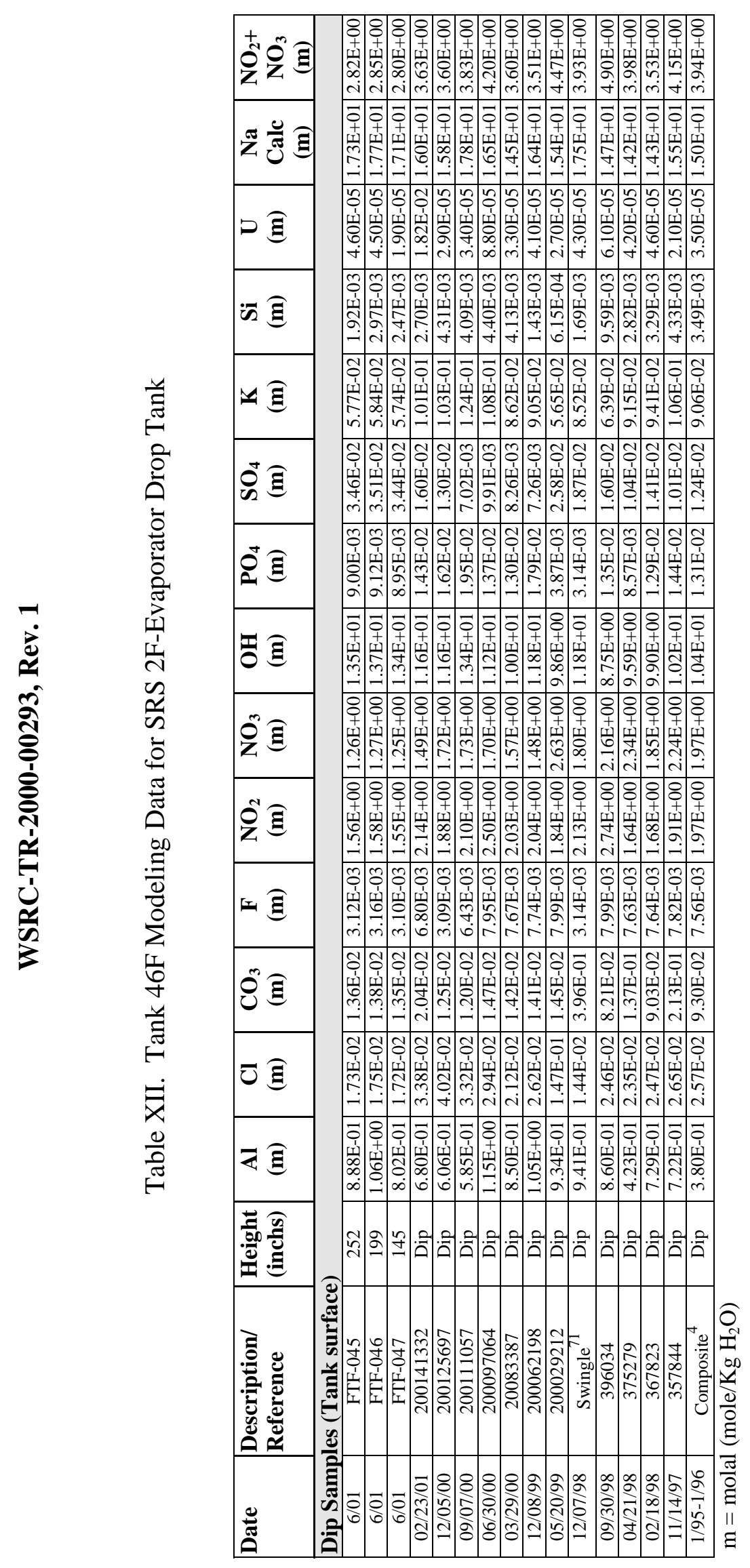

$\hat{N}$ 


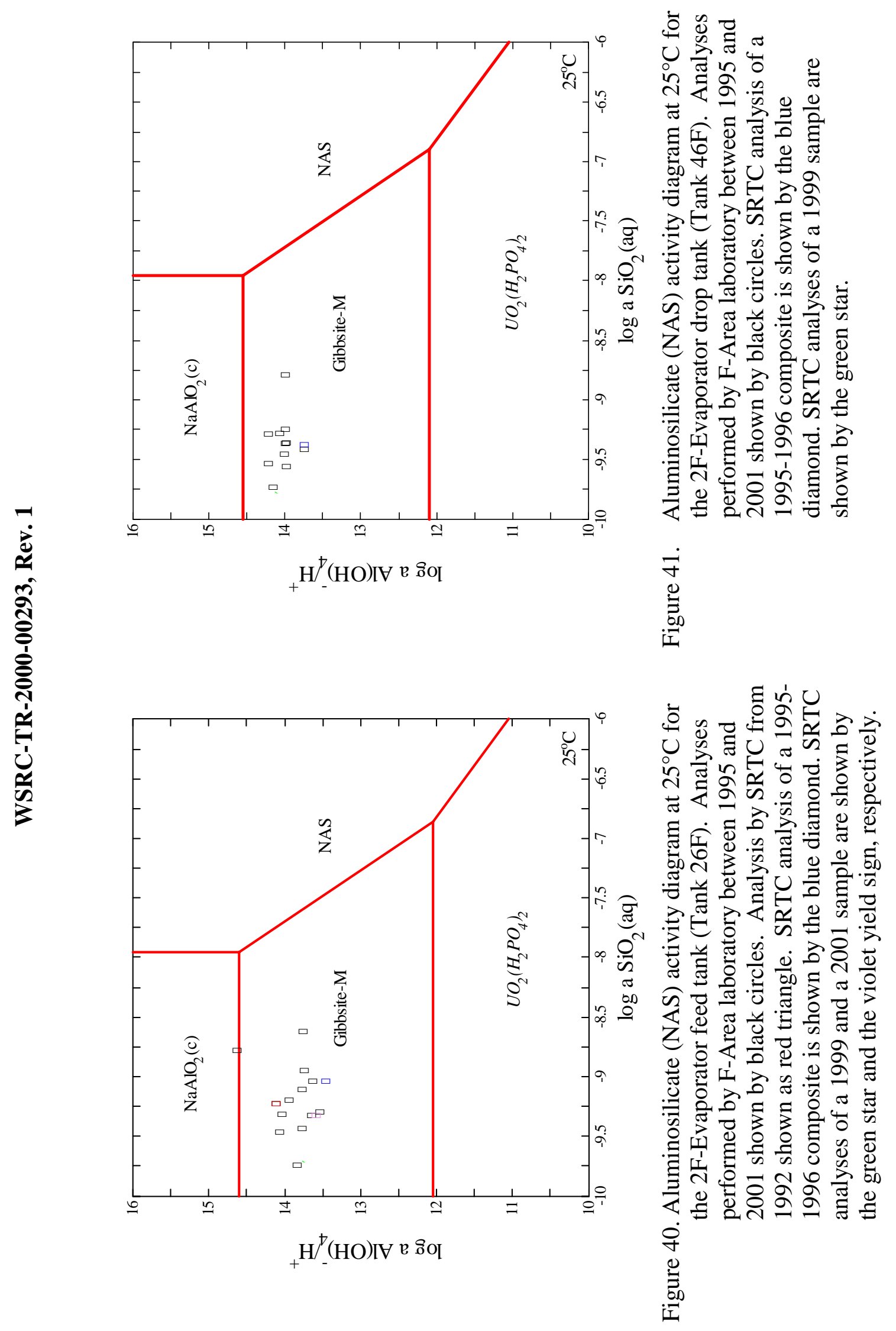




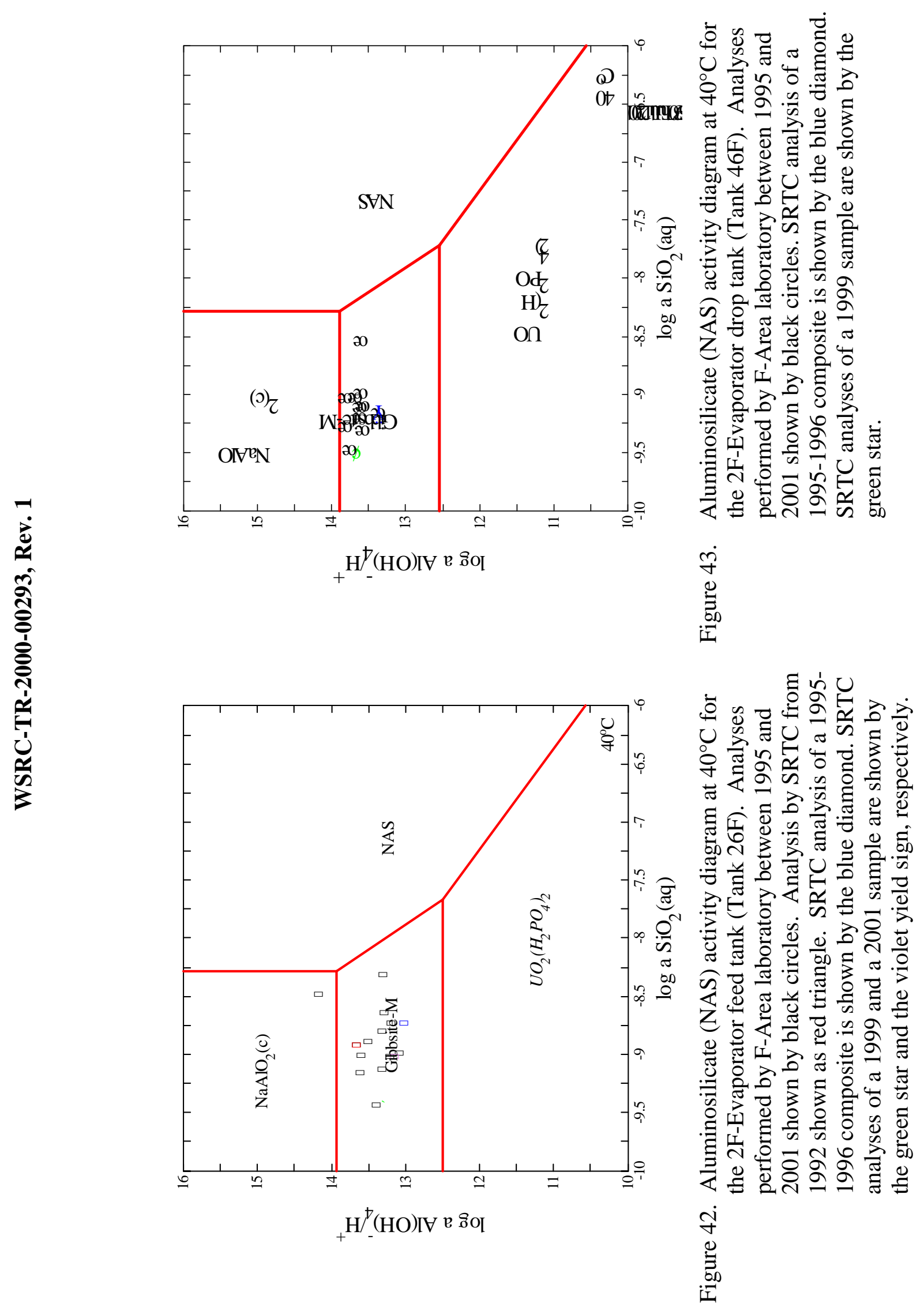




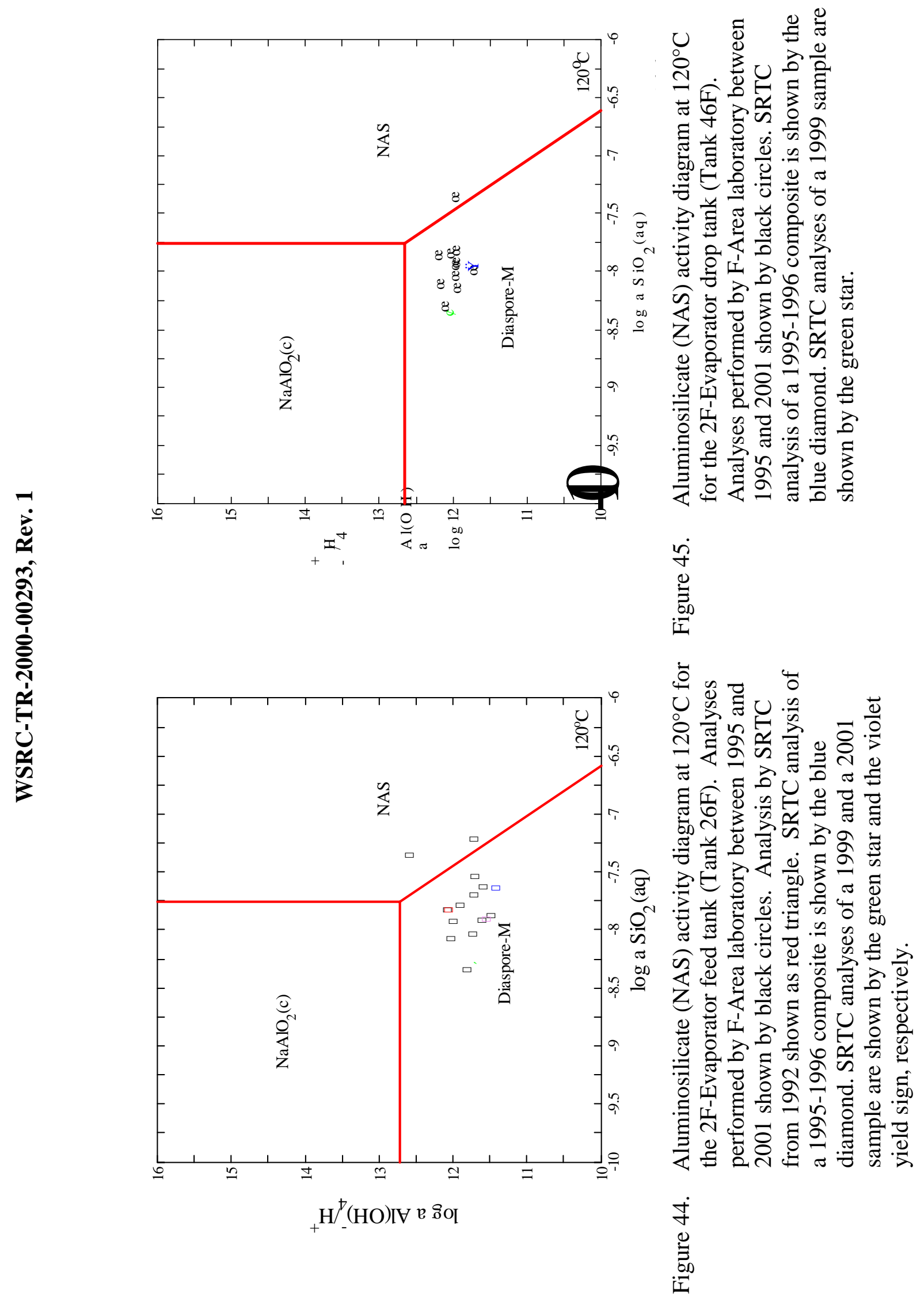




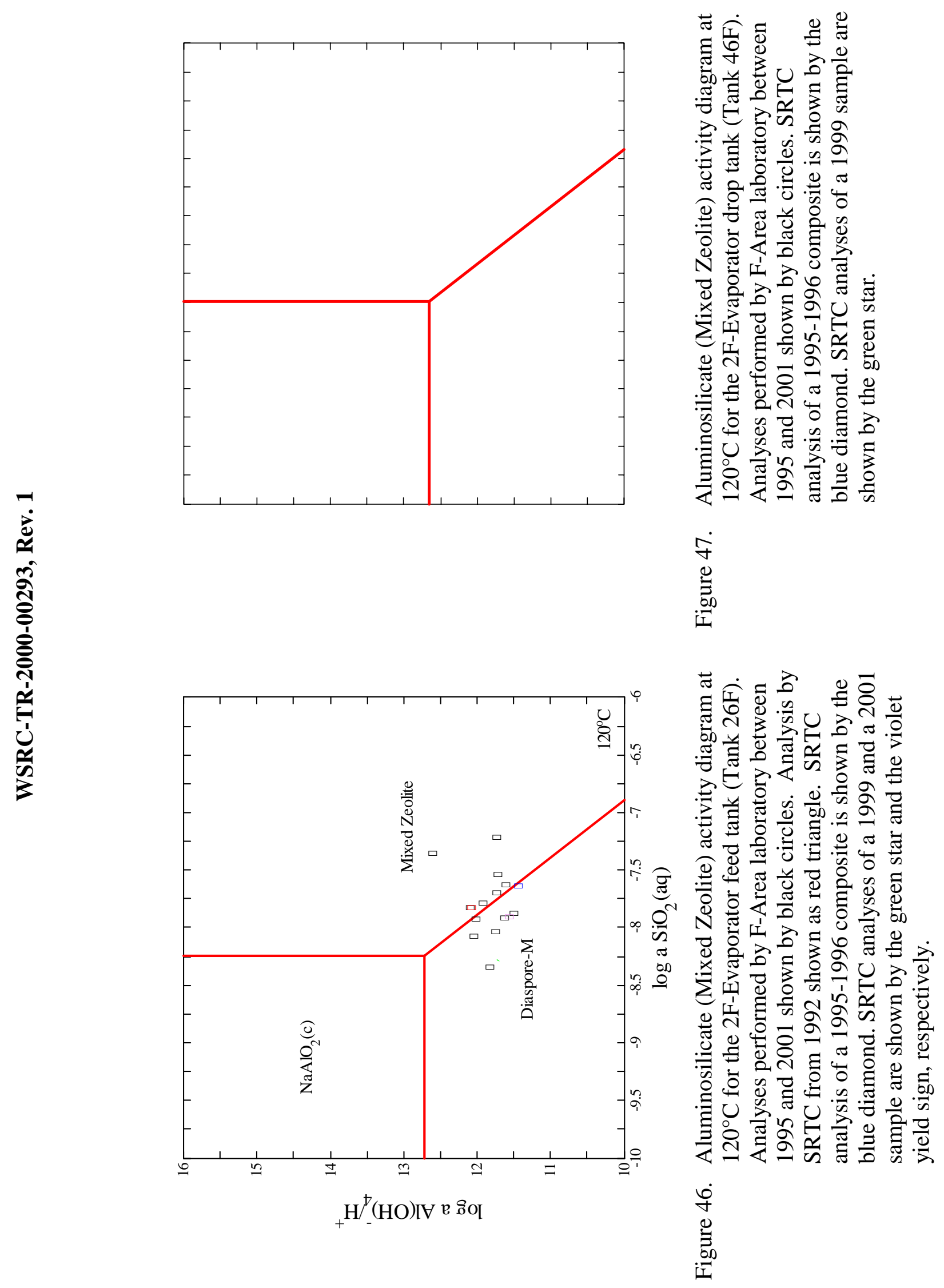




\subsection{CURRENT VS. HISTORIC OPERATION OF ALL SRS EVAPORATORS}

The historic evaporator feed tank and drop tank data is compared to the recent tank data for the SRS 3H, 2H, and 2F-Evaporator systems in Figure 48. The SRS 3H Evaporator feed tank analyses indicate that the wastes have become slightly more Si enriched since 1992 although this is not verified by the 1992 versus recent analyses of the $3 \mathrm{H}$ drop tank nor the $2 \mathrm{H}$ system tanks. Obviously, the $2 \mathrm{H}$ feed tank became more silica rich intermittently due to SME carryovers from the DWPF. More data is needed to verify if this is a trend, which should be monitored as a function of time if inter-area transfers become more frequent.

\subsection{SUPERSATURATION OF THE SRS 2H-Evaporator SYSTEM COMPARED TO THE 3H AND 2F-Evaporator SYSTEMS}

The GWB software has enabled the calculation of polythermal reaction paths at the tank temperatures $\left(\sim 40^{\circ} \mathrm{C}\right)$ and evaporator temperatures $\left(\sim 120^{\circ} \mathrm{C}\right)$. A simulated evaporation was performed by removing a percentage of the water from the calculation, e.g. the calculation was based on $0.6 \mathrm{~kg}$ of water rather than on the default of $1 \mathrm{~kg}$ of water for a simulated $40 \%$ evaporation. There are two options in the GWB software, one that suppresses all solid phase formation and calculates the supersaturation of the solid species and one that allows solid phase formation so that the amount of precipitate can be calculated. When all solid phase precipitation is suppressed, GWB calculates a supersaturation index for each solid phase expressed as a ratio of the reaction quotient (Q) over the theoretical solubility product $(\mathrm{K})$, e.g. a supersaturation index called $\mathrm{Q} / \mathrm{K}$. When solid phase precipitation is allowed, GWB calculates the amount of the solid phase that will precipitate in a $\mathrm{kg}$ of solution at equilibrium, e.g. $\mathrm{g}_{\text {(solid) }} / \mathrm{kg}_{(\text {soln) }}$. Since the short duration of the evaporator residence time causes the system to be in steady state equilibrium rather than long term equilibrium, the supersaturation index of the two primary phases most likely to form, $\mathrm{NAS}_{\text {gel }}$ and mixed zeolite, were modeled preferentially to the amount precipitated.

The GWB subroutine REACT which is used to calculate the solution activities for the activity diagrams presented in this study also calculates the degree of supersaturation of a solution with respect to all the solid phases of interest. The degree of supersaturation is expressed as the $\mathrm{Q} / \mathrm{K}$ ratio. A negative $\mathrm{Q} / \mathrm{K}$ indicates that a solution is undersaturated with respect to the aluminosilicate $\mathrm{NAS}_{\mathrm{gel}}$ and/or mixed zeolite and not likely to precipitate unless seed crystals are present. A positive number indicates supersaturation with respect to the aluminosilicate $\mathrm{NAS}_{\text {gel }}$ and/or mixed zeolite formation and a likely tendency for precipitation of that phase. Table XIII and Table XIV list the Q/K values (REACT output) for the 2H-Evaporator feed and drop tanks while Table XV and Table $\mathrm{XVI}$ list the $\mathrm{Q} / \mathrm{K}$ values for the $2 \mathrm{~F}$-Evaporator feed and drop tanks with and without a simulated $40 \%$ evaporation.

Modeling the SRS $2 \mathrm{H}$-Evaporator solutions at $120^{\circ} \mathrm{C}$ with and without simulated evaporation demonstrated that the solutions were saturated with respect to NAS and 


\section{WSRC-TR-2000-00293, Rev. 1}

mixed zeolite, e.g. feed tank mixtures had a positive $\mathrm{Q} / \mathrm{K}$ ratio in Table XIII both before and after additional evaporation, during the initial high silica/low alumina processing (February 1996 and May 1997). At this time the feed pump was at an elevation of 64" and the DWPF had just begun initial operations. These values are based on estimates of the Si concentration taken from the 64" analysis performed by Wilmarth dated 1/16/00 in Table XIII. During this time regime the DWPF had frequent SME carryovers which contained a great deal of silica rich glass forming frit. At this same time the feed pump was in or very close to the ZOT which is an enriched layer of unsettled silica colloids.

The results in Table XIII for the February 1996 to May 1997 operation of the SRS 2HEvaporator agree with the data in Figure 14 and Figure 16 which demonstrate that the tank supernates were supersaturated with respect to aluminosilicate NAS $_{\text {gel }}$ or mixed zeolite) at $120^{\circ} \mathrm{C}$ before being sent to the evaporator. The $\mathrm{Q} / \mathrm{K}$ ratios in Table XIII are in agreement with the aluminosilicate $\mathrm{K}_{\mathrm{sp}}$ determined experimentally and recently used by Wilmarth ${ }^{36,37}$ to determine the acceptability of supernates for processing in the SRS $3 \mathrm{H}$ Evaporator, e.g., if the [Al] ${ }^{*}[\mathrm{Si}]$ in $\mathrm{M}^{2}$ is in the $2 \times 10^{-4}$ to $8 \times 10^{-4}$ range then the supernates are acceptable for processing in the SRS evaporators. The values for this $\mathrm{K}_{\mathrm{sp}}$ based on room temperature chemical data are shown in Table XIII for comparison. The [Al]*[Si] in $\mathrm{M}^{2}$ of the solutions in Table XIII for the February 1996 to May 1997 time frame are in the $10^{-2}$ range, much greater that the specified $10^{-4}$ range. This indicates that the SRS $2 \mathrm{H}-$ Evaporator feeds were highly enriched in Si during this time frame. In addition, one of the first feeds to the SRS 2H-Evaporator were the HEME/HEPA digests that contained zeolite crystals which could act as seeds for precipitation.

In June 1997 the feed pump in the SRS 2H-Evaporator was raised to 100" and DWPF learned to control the SME carryovers. At the same time, the H-Canyon was sending minimal alumina rich material to the feed tank. The ensuing feed to the evaporator was less silica rich and less alumina rich as reflected in the negative $\mathrm{Q} / \mathrm{K}$ ratios (with or without simulated evaporation) in Table XIII and Table XIV from late 1997 to February 1998. During this time period the $[\mathrm{Al}]^{*}[\mathrm{Si}]$ in $\mathrm{M}^{2}$ of the feed tank remained in the $10^{-4}$ range recently used by Wilmarth ${ }^{36,37}$ to determine the acceptability of supernates for processing in the SRS 3H-Evaporator. Conversely, the solutions analyzed from the drop tank indicated that the $\mathrm{Q} / \mathrm{K}$ ratios for this time period were gradually becoming more and more positive from October1997 to February 1998. This is most apparent for the cases with simulated evaporation.

When H-Canyon began sending larger concentrations of alumina to the SRS $2 \mathrm{H}$ Evaporator feed tank during the May 1998 to August 1999 time frame, the Q/K ratios in Table XII for NAS and mixed zeolite at $120^{\circ} \mathrm{C}$ gradually became more positive based on F-area laboratory Si data. The data for the drop tank (Table XIV) indicates that the solutions exiting the evaporator were supersatured as exhibited by the drop tank $Q / K$ values for mixed zeolite in March 1999 and August 1999. The positive trend of the Q/K for the feed and drop tanks with time follows the increasing operational difficulty of the SRS 2H-Evaporator. During this time period, the [Al]*[Si] in $\mathrm{M}^{2}$ ranged from acceptable $\left(<10^{-4}\right)$ to unacceptable $\left(>10^{-4}\right)$ (see Table XIII and Table XIV). Even though the values in Table XIII are mostly negative during this time frame it must be recalled that (1) these analyses represent a "before evaporation"case, (2) the silica content at or near the feed pump could have been higher than the amount analyzed in the dip samples and (3) zeolite 


\section{WSRC-TR-2000-00293, Rev. 1}

seed material was present from the GDL, lift line, and demister flushes so that even undersaturated solutions could crystallize and cause evaporator fouling.

Table XIII indicates that the solutions in the feed tank to the SRS 2H-Evaporator since evaporator shutdown are not supersaturated with respect to NAS or zeolite before evaporation. However, with $40 \%$ evaporation there may be a tendency to precipitate as indicated by the 12/23/00 sample in Table XIII which is an analysis by the F-area laboratory. Corresponding Si analyses by Wilmarth in January 2000 at the tank surface (dip sample) and at the pump height (100") indicate that Tank $43 \mathrm{H}$ is not supersaturated with respect to either NAS or mixed zeolite. The sample at 64" is considered to be in the ZOT where NAS or mixed zeolite could easily precipitate but this material is below the zone of influence of the pump. The corresponding analyses of the SRS 2H-Evaporator drop tank (Table XIV) indicates that the drop tank is not supersaturated with respect to the NAS but may be after $40 \%$ evaporation.

The Q/K values for NAS precipitation in Table XV and Table XVI for the SRS 2FEvaporator feed and drop tanks are all negative indicating undersaturation with respect to NAS. One sample in Tank 26F with a positive Q/K (dated 12/02/98) is a detection limit value and not a real value. Table Table XV indicates that the SRS 2F-Evaporator feed $\operatorname{tank} \mathrm{Q} / \mathrm{K}$ values for mixed zeolite are positive for the data dated 5/18/99 and 6/30/00. Since this data was analyzed by the F-area laboratory, which is known to be biased high, and since the corresponding values for the $\mathrm{Q} / \mathrm{K}$ of the NAS are negative, it is unlikely that the SRS 2F System is precipitating mixed zeolite. Likewise the values of $\mathrm{Q} / \mathrm{K}$ for the drop tank (see Table XVI) are also mostly negative for NAS with or without simulated evaporation.

The data in this study indicates that the SRS 2F-Evaporator system is not supersaturated with respect to the precipitation of NAS and hence nitrated sodalite/cancrinite. Likewise, the data in Part $\mathrm{II}^{3}$ of this study shows that the SRS 3H-Evaporator system is not supersaturated with respect to the precipitation of NAS and hence nitrated sodalite/cancrinite. There is evidence in this study that the $2 \mathrm{H}$ system was supersaturated with respect to NAS and hence nitrated sodalite/cancrinite during two different time regimes. The first time regime was during initial startup of the SRS $2 \mathrm{H}$-Evaporator when the feed pump was in the ZOT (at a height of 64") and when the DWPF had multiple large SME carryovers of DWPF glass making frit in the presence of zeolite seed crystals from the HEME/HEPA filter digests processed early in the history of the SRS $2 \mathrm{H}$ Evaporator. The second time regime for the fouling of the SRS 2H-Evaporator was when DWPF had better control of the SME carryovers but H-Canyon began sending large concentrations of Al-rich feed to Tank $43 \mathrm{H}$. 
WSRC-TR-2000-00293, Rev. 1

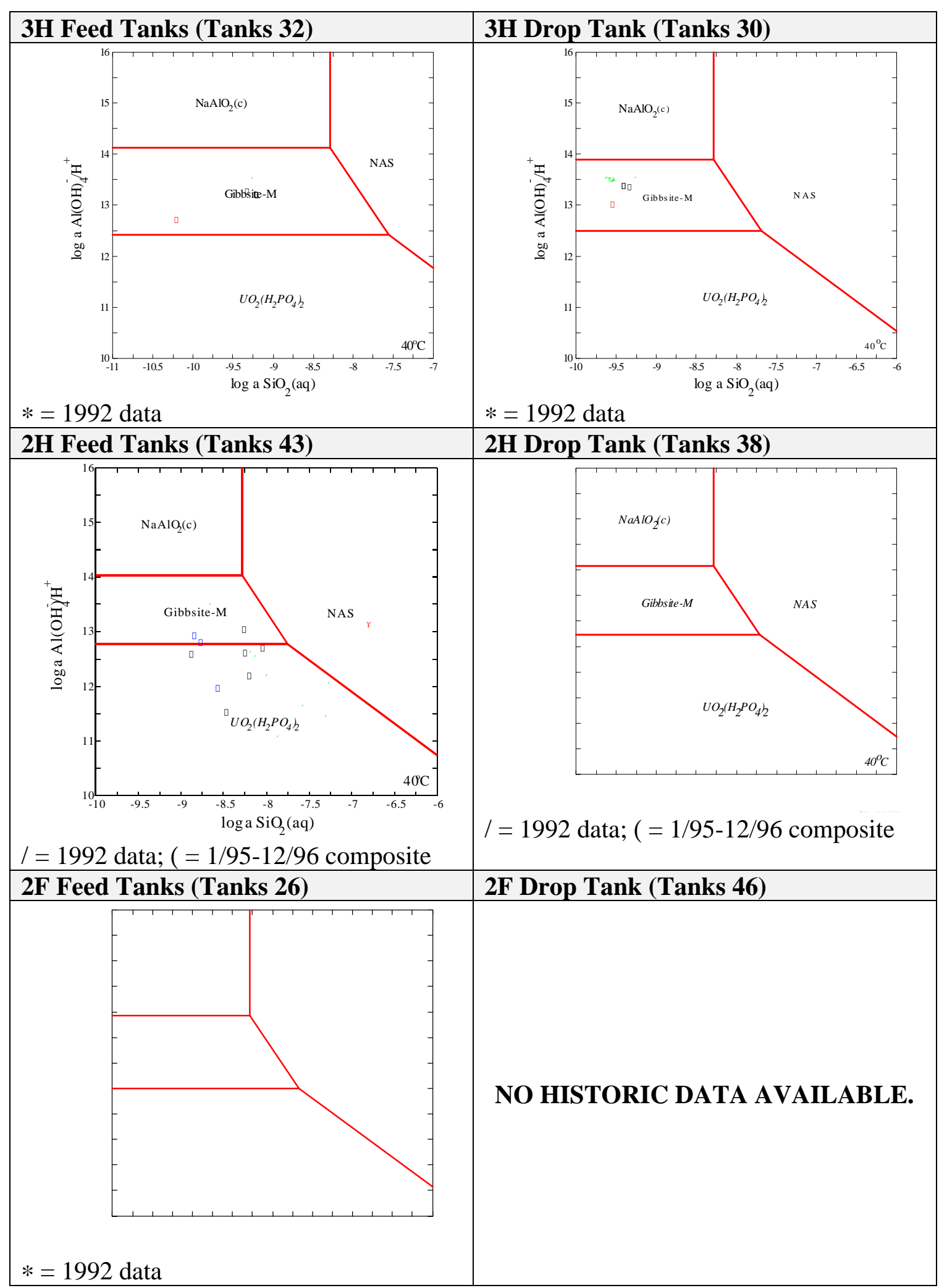

Figure 48. Comparison of 1992 historic data to current operational data for the SRS 3H, $2 \mathrm{H}$ and $2 \mathrm{~F}$-Evaporators at the tank temperature of $40^{\circ} \mathrm{C}$. 


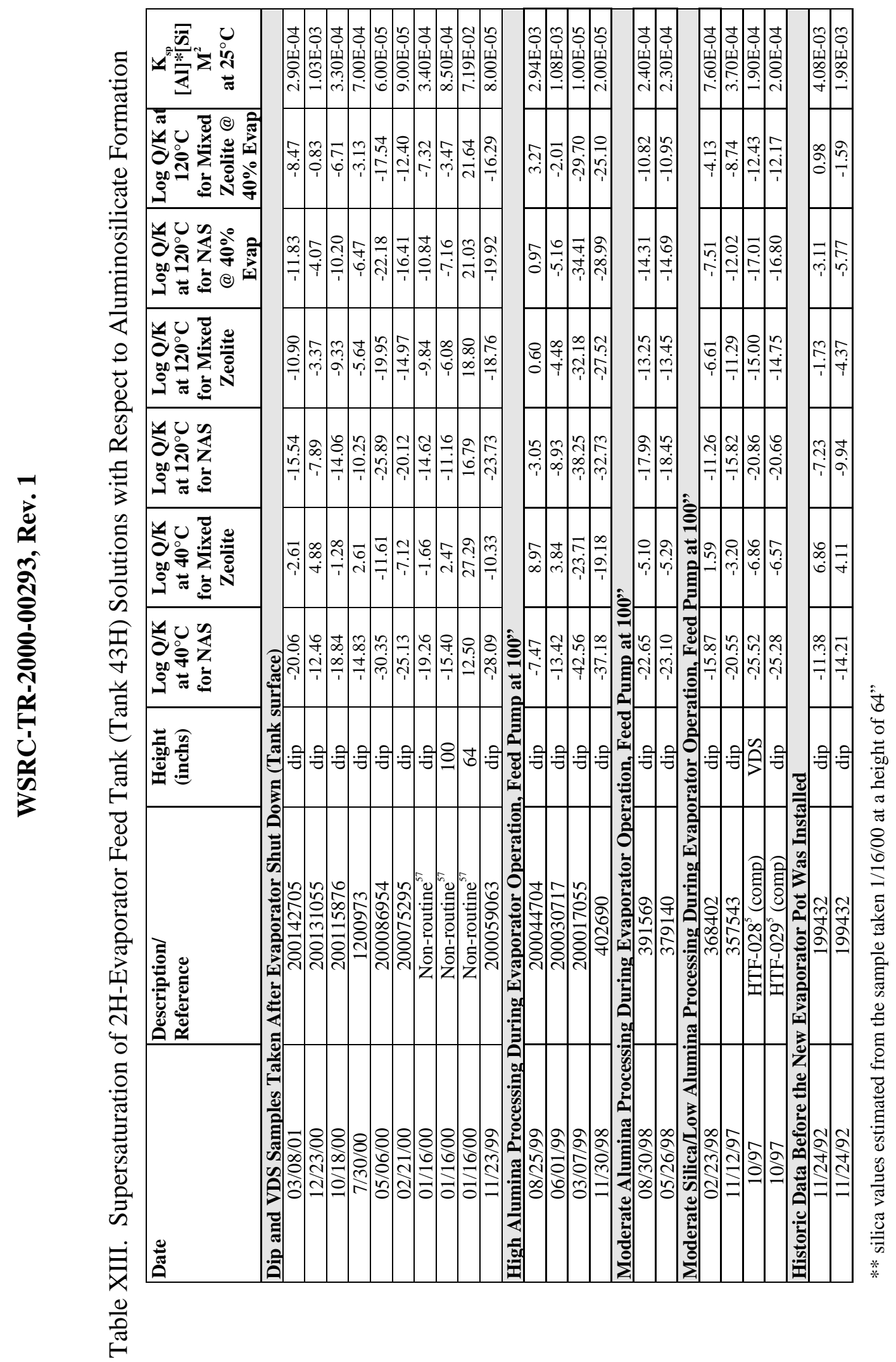

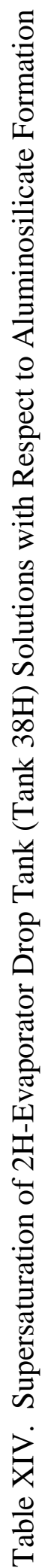




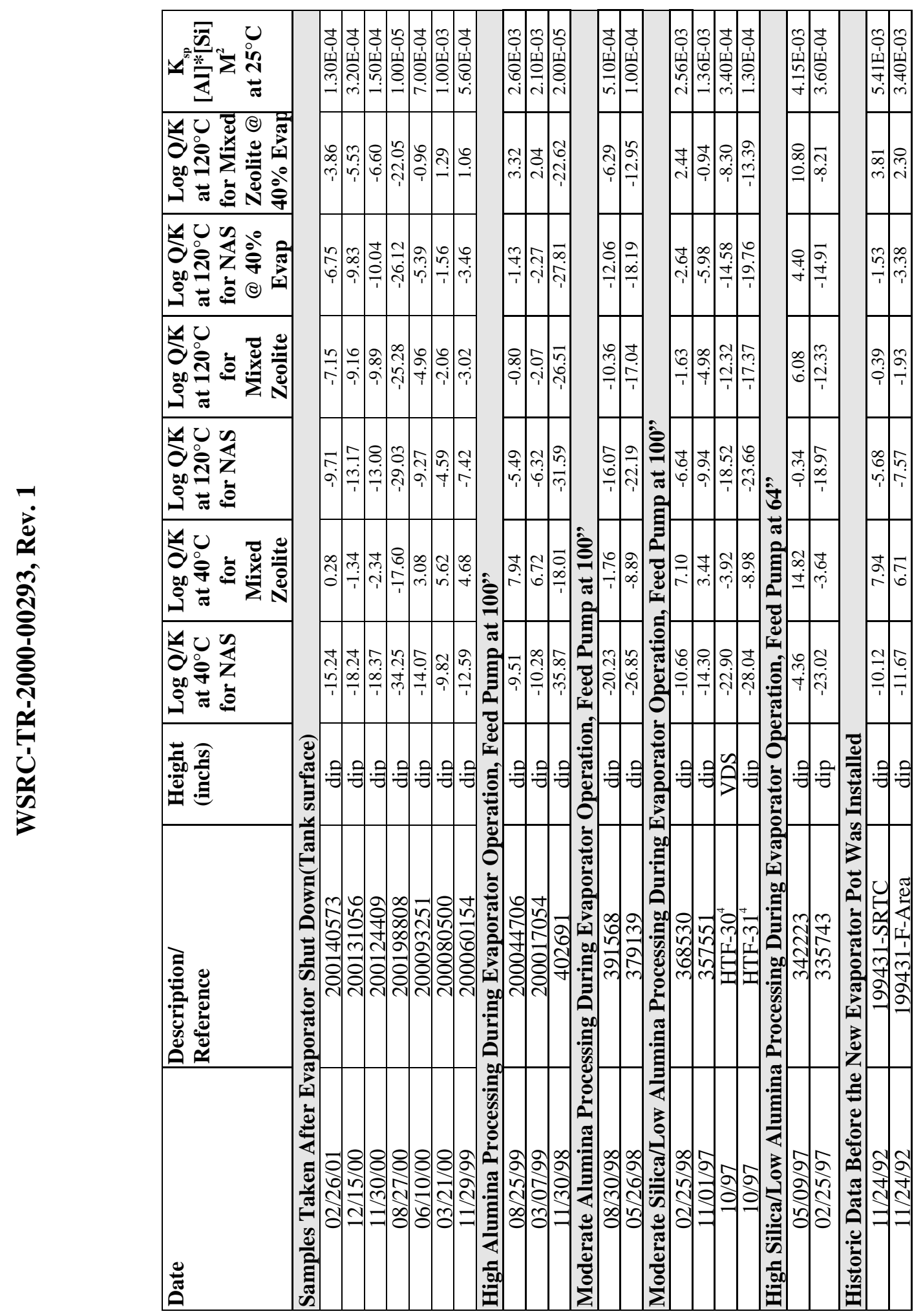




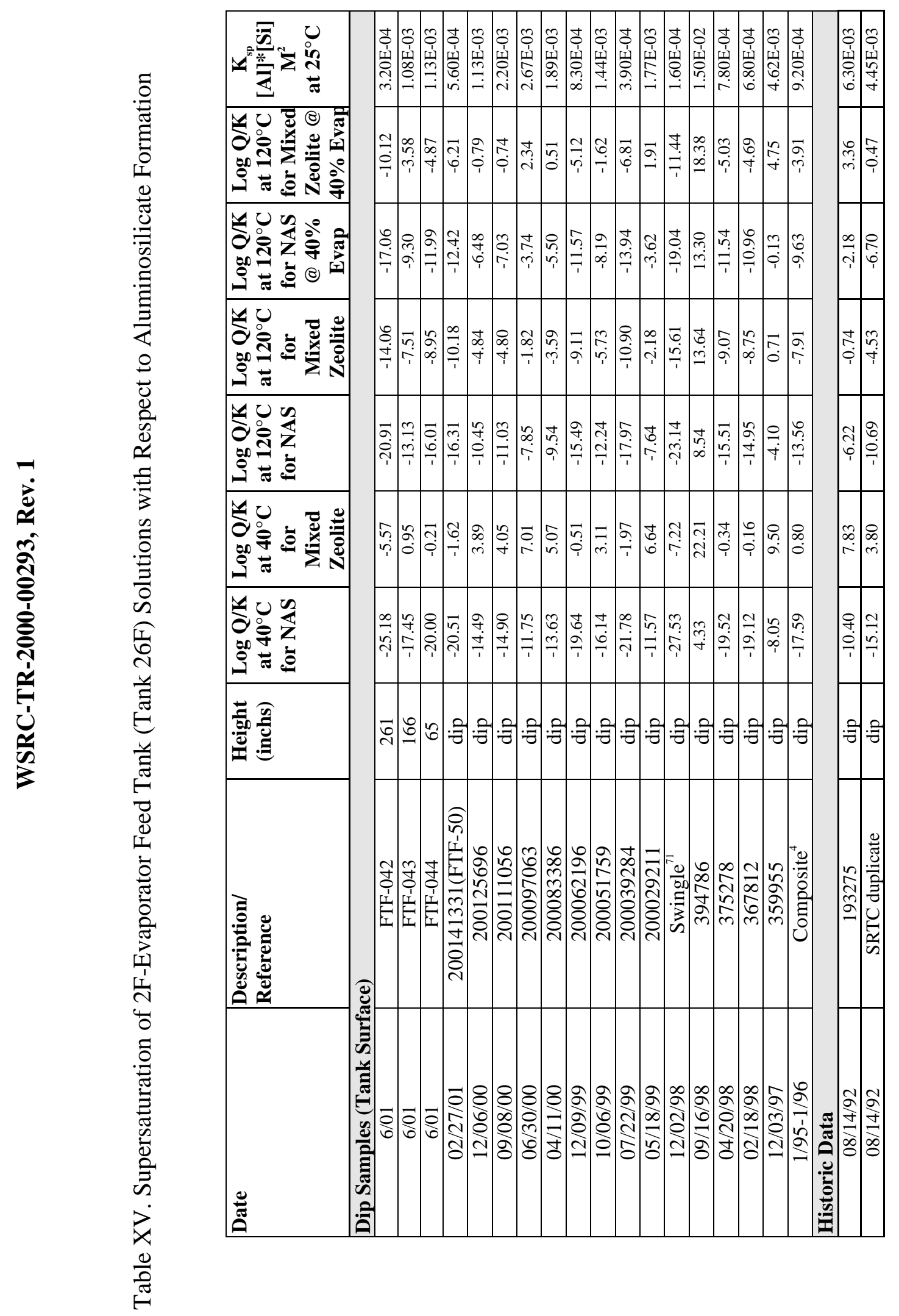




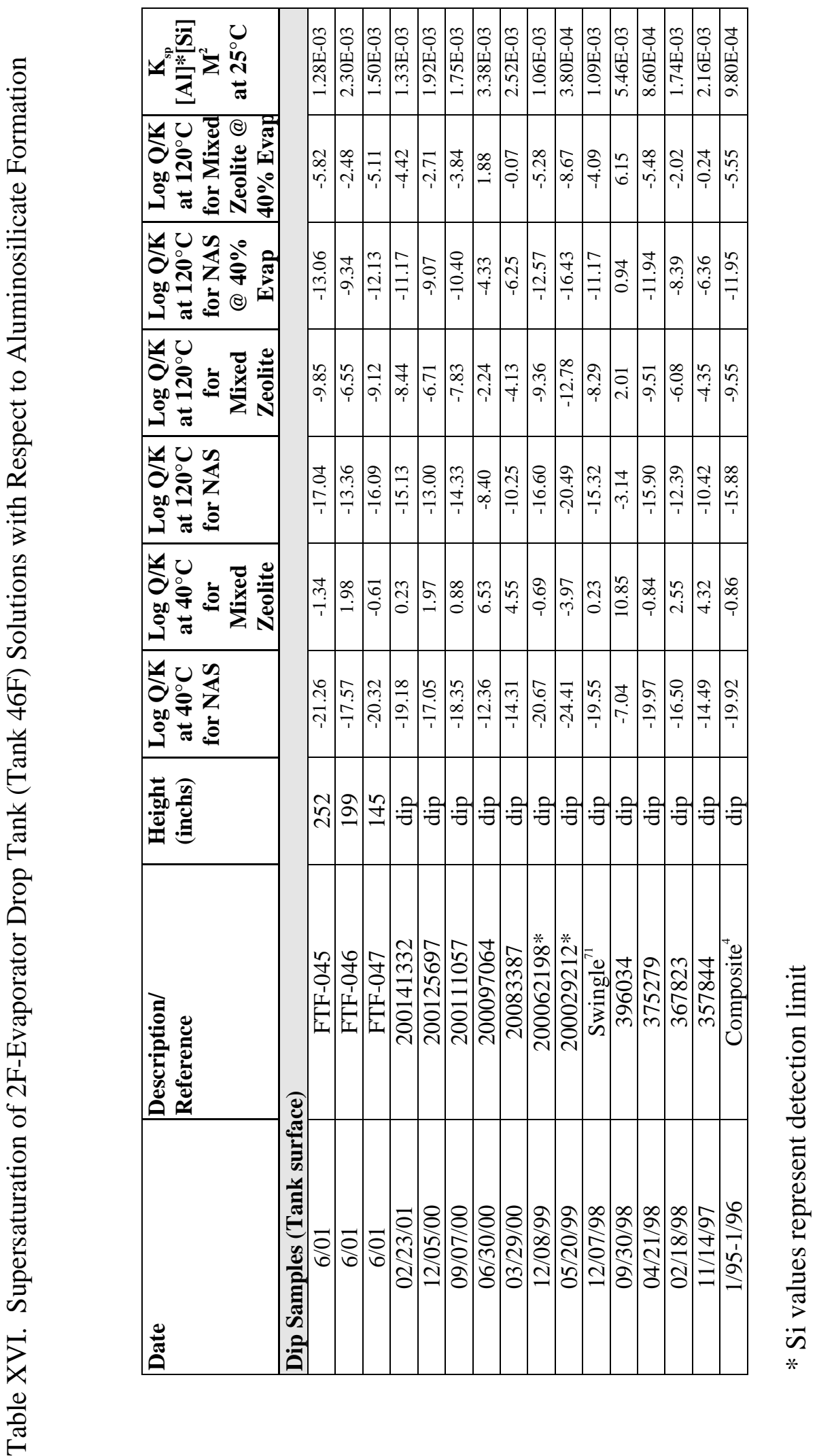




\subsection{A PROCESS MODEL FOR OPERATION OF SRS EVAPORATORS}

In order to quantify the activity boundaries into a process control model for routine operations by the SRS 2H-Evaporator and other SRS evaporators, a process control algorithm was developed based on Equation 17a. Equation 17a (reproduced below) represents the steady state equilibrium boundary on the activity diagrams which separates the field of $\mathrm{AlOOH}$ (diaspore) from the field of $\mathrm{NAS}_{\mathrm{gel}}$ at $120^{\circ} \mathrm{C}$ as presented in Section 7.1 (Figures 30 and 31).

$$
6 \text { Diaspore }+19 \mathrm{H}_{2} \mathrm{O}+6 \frac{\mathrm{Al}(\mathrm{OH})_{4}^{-}}{\mathrm{H}^{+}}+14 \mathrm{SiO}_{2}(\mathrm{aq})+12 \mathrm{Na}^{+} \Leftrightarrow \mathrm{NAS}_{\mathrm{gel}}
$$

Equation 17 a can be rewritten as

$$
\begin{aligned}
& 6 \mathrm{AlOOH}+19 \mathrm{H}_{2} \mathrm{O}+6 \mathrm{Al}(\mathrm{OH})_{4}^{-}+14 \mathrm{SiO}_{2}(\mathrm{aq})+12 \mathrm{Na}^{+} \\
& \Leftrightarrow \mathrm{Na}_{12} \mathrm{Al}_{12} \mathrm{Si}_{14} \mathrm{O}_{52} \bullet 31 \mathrm{H}_{2} \mathrm{O}+6 \mathrm{H}^{+}
\end{aligned}
$$

where the $\mathrm{NAS}_{\text {gel }}$ formula $\mathrm{Na}_{12} \mathrm{Al}_{12} \mathrm{Si}_{14} \mathrm{O}_{52} \bullet 31 \mathrm{H}_{2} \mathrm{O}$ is equivalent to $6\left(\mathrm{Na}_{2} \mathrm{O} \bullet \mathrm{Al}_{2} \mathrm{O}_{3} \cdot 2.32 \mathrm{SiO}_{2} \cdot 5.15 \mathrm{H}_{2} \mathrm{O}\right)$, the chemical composition of the $\mathrm{NAS}_{\text {gel }}$ from Ejaz. $^{23}$

The $\mathrm{K}_{\mathrm{sp}}$ for this reaction is

$$
\mathrm{K}_{\mathrm{sp}}\left(\mathrm{NAS}_{\mathrm{gel}}\right)=\frac{\left[\mathrm{NAS}_{\mathrm{gel}}\right]\left[\mathrm{H}^{+}\right]^{6}}{[\mathrm{AlOOH}]^{6}\left[\mathrm{Al}(\mathrm{OH})_{4}^{-}\right]^{6}\left[\mathrm{SiO}_{2}\right]^{14}\left[\mathrm{Na}^{+}\right]^{12}\left[\mathrm{H}_{2} \mathrm{O}\right]^{19}}
$$

Equation [24] can be further simplified since the $\mathrm{NAS}_{\text {gel }}$ in the numerator and the water in the denominator are in their standard states and equal to 1 as shown in Equation [25]

$$
\mathrm{K}_{\mathrm{sp}}\left(\mathrm{NAS}_{\mathrm{gel}}\right)=\frac{\left[\mathrm{H}^{+}\right]^{6}}{[\mathrm{AlOOH}]^{6}\left[\mathrm{Al}(\mathrm{OH})_{4}{ }^{-}\right]^{6}\left[\mathrm{SiO}_{2}\right]^{14}\left[\mathrm{Na}^{+}\right]^{12}}
$$

or in logarithmic form

$$
\begin{aligned}
& \log \mathrm{K}_{\mathrm{sp}}\left(\mathrm{NAS}_{\mathrm{gel}}\right)=6 \log \left[\mathrm{H}^{+}\right]-6 \log [\mathrm{AlOOH}]-6 \log \left[\mathrm{Al}(\mathrm{OH})_{4}{ }^{-}\right]- \\
& 14 \log \left[\mathrm{SiO}_{2}\right]-12 \log \left[\mathrm{Na}^{+}\right]
\end{aligned}
$$

Use of Equation [26] for the development of a process control algorithm would result in relying on a measurement of the $\mathrm{pH}$ which is inherently inaccurate at $\mathrm{pH}$ values of $>13$, the $\mathrm{pH}$ values reported for the SRS evaporator feeds. This is due to the inherent difficulties of measuring $\mathrm{pH}$ in very alkaline solutions with "general purpose" electrodes that are most efficient in the $\mathrm{pH}$ range of 1 to 11 . In higher $\mathrm{pH}$ solutions the hydrogen 


\section{WSRC-TR-2000-00293, Rev. 1}

ion activity is so low, and the activity of the alkali or alkaline earth ions so high, that the ordinary $\mathrm{pH}$ electrode begins to respond to the alkali or alkaline earth in solution rather than the concentration of $\left[\mathrm{H}^{+}\right]$. $^{7,72}$ For measurements of $\mathrm{pH}$ values above 11 , special "high $\mathrm{pH}$ " electrodes are recommended for accurate work. ${ }^{7}$ Since, general purpose electrodes were used for evaporator feed tank measurements the use of $\mathrm{pH}$ introduces a great deal of error into any potential process model developed based on Equation [26].

Free hydroxide is routinely measured for the SRS evaporators and it is a more accurate measurement than the $\mathrm{pH}$. Hence, Equation [23] was rewritten so that it depended on $\log \left[\mathrm{OH}^{-}\right]$. The $\mathrm{SiO}_{2}(\mathrm{aq})$ in $\mathrm{GWB}$ represents silicic acid which can be represented in hydroxide form as $\mathrm{Si}(\mathrm{OH})_{4}$. Likewise, the $\mathrm{Na}^{+}$should be expressed as $\mathrm{NaOH}$ consistent with Equation 1 and the work of Mattigod and McGrail. ${ }^{73}$

$$
\begin{aligned}
& 6 \mathrm{AlOOH}+6 \mathrm{Al}(\mathrm{OH})_{4}^{-}+14 \mathrm{Si}(\mathrm{OH})_{4}(\mathrm{aq})+12 \mathrm{NaOH} \\
& \Leftrightarrow \mathrm{Na}_{12} \mathrm{Al}_{12} \mathrm{Si}_{14} \mathrm{O}_{52} \bullet 31 \mathrm{H}_{2} \mathrm{O}+15 \mathrm{H}_{2} \mathrm{O}+6 \mathrm{OH}^{-}
\end{aligned}
$$

The $\mathrm{K}_{\mathrm{sp}}$ for this reaction is

$$
\mathrm{K}_{\mathrm{sp}}\left(\mathrm{NAS}_{\mathrm{gel}}\right)=\frac{\left[\mathrm{NAS}_{\mathrm{gel}}\right]\left[\mathrm{OH}^{-}\right]^{6}\left[\mathrm{H}_{2} \mathrm{O}\right]^{15}}{[\mathrm{AlOOH}]^{6}\left[\mathrm{Al}(\mathrm{OH})_{4}{ }^{-}\right]^{6}\left[\mathrm{Si}(\mathrm{OH})_{4}\right]^{14}[\mathrm{NaOH}]^{12}}
$$

Equation [28] can be further simplified since the $\mathrm{NAS}_{\text {gel }}$ in the numerator and the water in the denominator are in their standard states and equal to 1 as shown in Equation [29]

$$
\mathrm{K}_{\mathrm{sp}}\left(\mathrm{NAS}_{\mathrm{gel}}\right)=\frac{\left[\mathrm{OH}^{-}\right]^{6}}{[\mathrm{AlOOH}]^{6}\left[\mathrm{Al}(\mathrm{OH})_{4}{ }^{-}\right]^{6}\left[\mathrm{Si}(\mathrm{OH})_{4}\right]^{14}[\mathrm{NaOH}]^{12}}
$$

or in logarithmic form

$$
\begin{aligned}
& \log \mathrm{K}_{\mathrm{sp}}\left(\mathrm{NAS}_{\mathrm{gel}}\right)=6 \log \left[\mathrm{OH}^{-}\right]-6 \log [\mathrm{AlOOH}]-6 \log \left[\mathrm{Al}(\mathrm{OH})_{4}{ }^{-}\right]- \\
& 14 \log \left[\mathrm{Si}(\mathrm{OH})_{4}\right]-12 \log [\mathrm{NaOH}]
\end{aligned}
$$

Rewriting Equation 30 in terms of the species measured in the SRS evaporator feed tanks, e.g. $\mathrm{Al}(\mathrm{M}), \mathrm{Si}(\mathrm{M}), \mathrm{OH}(\mathrm{M})$, and $\mathrm{Na}(\mathrm{M})$, multiplying both sides by -1 , and assuming that the $\mathrm{Al}$ from $\mathrm{AlOOH}$ exists in an aqueous form because diaspore is not kinetically favored to form in the short evaporator time frames gives the following equation:

$$
\begin{aligned}
& -\log \mathrm{Q}\left(\mathrm{NAS}_{\mathrm{gel}}\right)_{25^{\circ} \mathrm{C}}=12 \log [\mathrm{Al}(\mathrm{M})]+14 \log [\mathrm{Si}(\mathrm{M})]+12 \log [\mathrm{Na}(\mathrm{M})]- \\
& 6 \log [\mathrm{OH}(\mathrm{M})]
\end{aligned}
$$

where the $\mathrm{K}_{\mathrm{sp}}\left(\mathrm{NAS}_{\mathrm{gel}}\right)_{25^{\circ} \mathrm{C}}$ is now expressed as the reaction quotient, $\mathrm{Q}\left(\mathrm{NAS} \mathrm{gel}_{\mathrm{ge}}\right)_{25^{\circ} \mathrm{C}}$, since actual tank sample data analyzed at $25^{\circ} \mathrm{C}$ is being modeled. 


\section{WSRC-TR-2000-00293, Rev. 1}

Equation 31 forms the basis for the relation of measured molar feed tank solutions at $25^{\circ} \mathrm{C}, \mathrm{Q}\left(\mathrm{NAS}_{\mathrm{gel}}\right)$, to the activity diagrams for $\mathrm{NAS}_{\mathrm{gel}}$ and to the calculated $\mathrm{Q} / \mathrm{K}$ from $\mathrm{GWB}$ at $120^{\circ} \mathrm{C}$ with $40 \%$ evaporation. This regression includes the conversion from molar concentration units to the molal concentration units used by GWB.

There were 101 data points available for relating the molar tank concentrations from Tables III, IV, VIII and IX in this study and Tables III and IV in Part I to the calculated $\mathrm{Q} / \mathrm{K}$ values in Tables XII-XV in this study and Table VII in Part I. Sixty nine samples were missing measured $\mathrm{Na}$ analyses. Regression of the remaining 32 data points gives the process control algorithm shown in Figure 49 with an adjusted $R^{2}$ of 0.80 and a root mean square error of 3.34. Most of the 32 data points were measurements made by SRTC since F-area laboratory does not routinely measure Na. The SRS 3H-Evaporator system data corresponded to operation at $\sim 140^{\circ} \mathrm{C}$ while the SRS $2 \mathrm{H}$ and $2 \mathrm{~F}$-Evaporator system data corresponded to operation at $\sim 120^{\circ} \mathrm{C}$. Regression with the corresponding temperatures indicated that the temperature was not a significant term in the model. The temperature dependence will be discussed in more detail in Part III. ${ }^{74}$ The lack of significant temperature dependence of the NAS precipitation is in agreement with the experimental data of Wilmarth ${ }^{36,37}$ who had shown that the apparent solubility product criteria, $[\mathrm{Al}] *[\mathrm{Si}]$ in $\mathrm{M}^{2} \sim 10^{-4}$ was temperature independent.

The correlation shown in Figure 49 relies only on the parameters in Equation 31. The correlation of the calculated $\mathrm{Q} / \mathrm{K}$ to Equation [31] gives a slope of 0.7379 and an intercept of 16.79 (see Figure 49). Note that all of the conversions from molar to molal concentrations and the activity coefficient estimations are summed up in the intercept term.

The 32 data points that were used to derive Figure 49 insufficiently cover the range of $\log \mathrm{Q}\left(\mathrm{NAS}_{\mathrm{gel}}\right)_{25^{\circ} \mathrm{C} \cdot}$. The majority of the data clusters in the center of Figure 49 and there are two high leverage points on the plot. In order to base the process control model on the 101 data points available, the relationship between $\log (\mathrm{Q} / \mathrm{K})_{120^{\circ} \mathrm{C} / 40 \% \text { evap }}$ was tested with and without the $\log [\mathrm{Na}(\mathrm{M})]$ term. To demonstrate that the $\log [\mathrm{Na}(\mathrm{M})]$ term has a minimum impact on the process control model even though the stepwise regression indicates that all the terms are significant, a standard regression analysis of $\log [\mathrm{Al}(\mathrm{M})], \log [\mathrm{Si}(\mathrm{M})]$, and $\log [\mathrm{OH}(\mathrm{M})]$ with and without $\log [\mathrm{Na}(\mathrm{M})]$ against $\log (\mathrm{Q} / \mathrm{K})_{120^{\circ} \mathrm{C} / 40 \% \mathrm{evap}}$ was performed. The equations with and without $\log [\mathrm{Na}(\mathrm{M})]$ are shown as Equations [32] and [33] below:

$$
\begin{aligned}
& \log (Q / K)_{120^{\circ} \mathrm{C} / 40 \% \text { evap }}=44.38+15.31 \log [\mathrm{Al}(\mathrm{M})]+13.99 \log [\mathrm{Si}(\mathrm{M})]+ \\
& 8.32 \log [\mathrm{Na}(M)]-24.06 \log [\mathrm{OH}(M)] \\
& \log (Q / K)_{120^{\circ} \mathrm{C} / 40 \% \text { evap }}=43.00+14.99 \log [\mathrm{Al}(\mathrm{M})]+13.34 \log [\operatorname{Si}(M)]- \\
& 14.01 \log [\mathrm{OH}(M)]
\end{aligned}
$$

Equation 32 is based on the same 29 data points as the correlation in Figure 49. The $\log [\mathrm{Na}(\mathrm{M})]$ and $\log [\mathrm{OH}(\mathrm{M})]$ are co-linear and related by the equation $\log [\mathrm{Na}(\mathrm{M})]=0.51$ $+0.615 \log [\mathrm{OH}(\mathrm{M})]$ with an $\mathrm{R}^{2}$ of 0.72 . Therefore, removal of the $\log [\mathrm{Na}(\mathrm{M})]$ from Equation [32] is balanced by a decrease in the coefficient of the $\log [\mathrm{OH}(\mathrm{M})]$ in Equation 


\section{WSRC-TR-2000-00293, Rev. 1}

[33]. The coefficients of the remaining terms (intercept, $\log [\mathrm{Al}(\mathrm{M})]$, and $\log [\operatorname{Si}(\mathrm{M})]$ ) in Equations [32] and [33] are similar. This test of the effect of removing the $\log [\mathrm{Na}(\mathrm{M})]$ term demonstrates that the $\log [\mathrm{Na}(\mathrm{M})]$ is adequately represented because of the colinearity of this term with the $\log [\mathrm{OH}(\mathrm{M})]$. A modified form of Equation [31], omitting $\log [\mathrm{Na}(\mathrm{M})]$, can then be used as the process control algorithm without loss of accuracy. The modified form of Equation [31] is

$$
-\log \mathrm{Q}\left(\mathrm{NAS}_{\mathrm{gel}}\right)_{25^{\circ} \mathrm{C}}=12 \log [\mathrm{Al}(\mathrm{M})]+14 \log [\mathrm{Si}(\mathrm{M})]-6 \log [\mathrm{OH}(\mathrm{M})]
$$

and is equivalent to writing Equation [27] without the $\mathrm{NaOH}$ term:

$$
\begin{aligned}
& 6 \mathrm{AlOOH}+6 \mathrm{Al}(\mathrm{OH})_{4}^{-}+14 \mathrm{Si}(\mathrm{OH})_{4}(\mathrm{aq}) \Leftrightarrow \mathrm{Al}_{12} \mathrm{Si}_{14} \mathrm{O}_{46} \bullet 31 \mathrm{H}_{2} \mathrm{O}+9 \mathrm{H}_{2} \mathrm{O} \\
& +6 \mathrm{OH}^{-}
\end{aligned}
$$

Equation [35] represents the formation of the aluminosilicate "cage" structure of the gel and/or mixed zeolite, sodalite, cancrinite. Basing the process control model on Equation [34] which is derived from Equation [35] allows one to use all 101 data points so that there is better spatial coverage of the data between the two high leverage points (Figure 50). The simplified model is based only on three chemical parameters that are routinely measured, e.g. $\log [\mathrm{Al}(\mathrm{M})], \log [\mathrm{Si}(\mathrm{M})])$, and $\log [\mathrm{OH}(\mathrm{M})]$. Equation [36] gives the simplified process control model based on Equation 34 .

$$
\begin{aligned}
& \log (Q / K)_{N A S 120^{\circ} C / 40 \% \text { evap }}=36.4450+0.9696(12 \log [A l(M)]+14 \log [\operatorname{Si}(M)] \\
& -6 \log [O H(M)]
\end{aligned}
$$

The $\mathrm{R}^{2}$ of the model using Equation [36] is 0.90 compared to 0.80 when using the measured $\mathrm{Na}$ values (see Figure 49). However, data from both F-area laboratory and SRTC are included in Figure 50. The SRTC measurements are shown in pink and the FArea laboratory data in gray.

The process models in Figure 49 and Figure 50 can be compared to the solubility product criteria, [Al]*[Si] in $\mathrm{M}^{2} \sim 10^{-4}$, recently used by Wilmarth ${ }^{36,37}$ to determine the acceptability of feed tank supernates for processing in the SRS 3H-Evaporator. The Wilmarth solubility product is shown in both figures compared to recent operational data for Tank 46F. Recent Tank 46F samples have been measured by SRTC and so the apparent operational limit shown in Figure 49 and Figure 50 is based on this qualified Si data (sample FTF-046). As qualified Si data is accumulated this apparent operational limit can be moved. There is evidence on Figure 49 from the one 1992 historic data point (Tank $38 \mathrm{H})$ that the operational limit may be more positive than -3.96 since silicate solutions can be $>200 \%$ supersaturated at temperature and not precipitate until cooled. ${ }^{75}$ 
WSRC-TR-2000-00293, Rev. 1

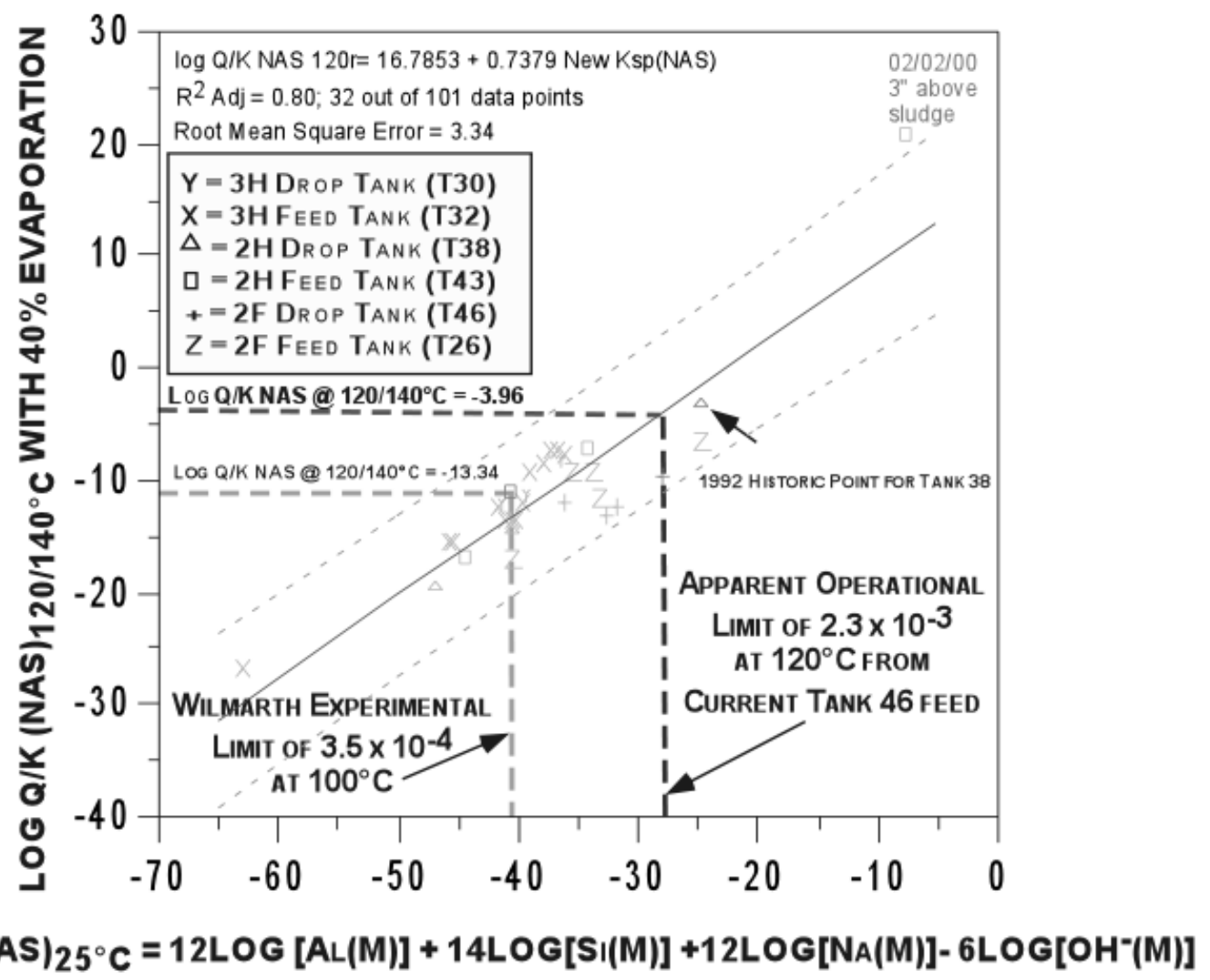

Figure 49. Potential process control model for the SRS evaporators. This model is based on the equilibrium between diaspore and $\mathrm{NAS}_{\text {gel }}$ represented on the activity diagrams in this report and Equations [27] to [31]. It allows parameters measured in the feed tanks to be directly compared to their potential to precipitate $\mathrm{NAS}_{\mathrm{gel}}$ after a $40 \%$ evaporation. The intercept includes the evaporation terms, the numeric conversions from molar to molal concentrations, corrections for the activity coefficients, and temperature corrections for the solubility of diaspore and $\mathrm{NAS}_{\text {gel. }}$ 


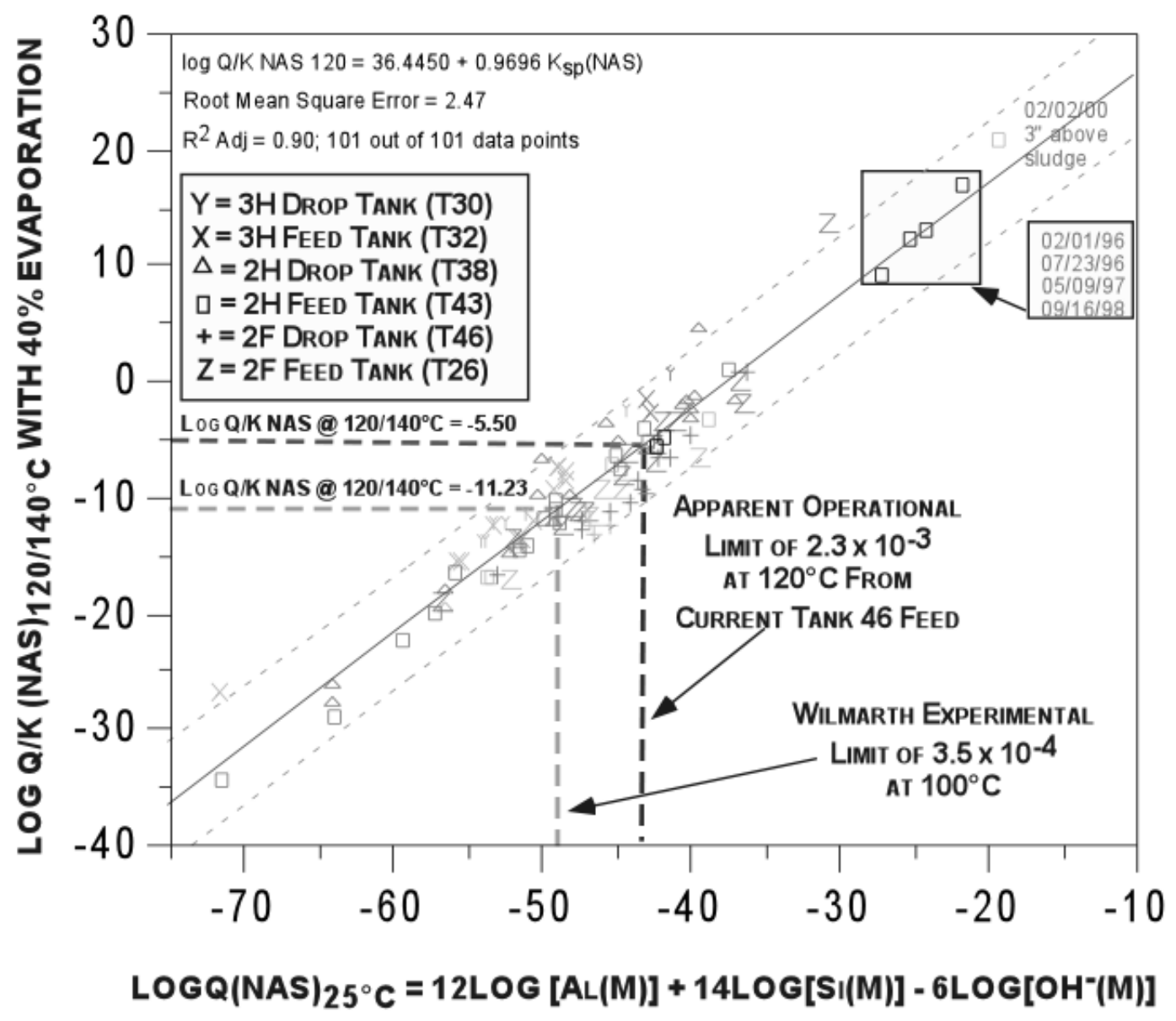

Figure 50. Simplified process control model for the SRS evaporators. This model is based on the equilibrium between diaspore and the $\mathrm{NAS}_{\text {gel }}$ without the $\log [\mathrm{Na}(\mathrm{M})]$ term. Mechanistically this is equivalent to writing an equilibrium equation for the formation of the $\mathrm{NAS}_{\text {gel }}$ cage as shown in Equation [35]. The simplified process control model allows parameters measured in the feed tanks to be directly compared to their potential to precipitate $\mathrm{NAS}_{\mathrm{gel}}$ after a $40 \%$ evaporation and does not require the measurement of $\mathrm{Na}(\mathrm{M})$ which is a measurement not routinely performed on evaporator feeds. The intercept includes the evaporation terms, the numeric conversions from molar to molal concentrations, corrections for the activity coefficients, and temperature corrections for the solubility of diaspore and $\mathrm{NAS}_{\text {gel }}$. Data points in black have estimated $\mathrm{Si}$ values and were not used in development of the model but are shown graphically to indicate the time regimes when the $2 \mathrm{H}$ Evaporator was supersaturated with respect to $\mathrm{NAS}_{\mathrm{gel}}$. 
There is also additional F-area data shown on Figure $50\left(\log (\mathrm{Q} / \mathrm{K})_{120^{\circ} \mathrm{C} / 40 \% \text { evap }}\right.$ values more positive than -3.96) of which many are known to be biased high. However, based on the one data point in Figure 49 and the remaining F-area data points shown in Figure 50 , it is likely that the operational limit is probably closer to a $\log (\mathrm{Q} / \mathrm{K})_{120^{\circ} \mathrm{C} / 40 \% \text { evap }}$ of $\sim 0$.

There is a strong correlation of the solubility product criteria, $\log \left([\mathrm{Al}]^{*}[\mathrm{Si}]\right)$ in $\mathrm{M}^{2} \sim 10^{-4}$, recently used by Wilmarth ${ }^{37,38}$ to $\log (\mathrm{Q} / \mathrm{K})_{120^{\circ} \mathrm{C} / 40 \% \text { evap }}$ because the $\log [\mathrm{Al}(\mathrm{M})]$ and the $\log [\mathrm{Si}(\mathrm{M})]$ are of approximately equivalent importance in Equation [34], e.g. they have coefficients of 12 and 14 respectively. However, the correlation of $\log \left([\mathrm{Al}]^{*}[\mathrm{Si}]\right)$ with $\log (\mathrm{Q} / \mathrm{K})_{120^{\circ} \mathrm{C} / 40 \% \text { evap }}$ gives an $\mathrm{R}^{2}=0.81$ and does not account for variation of $\mathrm{OH}^{-}$ concentration in the evaporators. Both of these provide less accuracy than the process model based on Equation [34].

It should be noted that the $2 / 2 / 2000$ sample taken 3 " from the sludge in Tank $43 \mathrm{H}$ (indicated in Figures 49 and 50) is supersaturated with respect to the $\mathrm{NAS}_{\mathrm{gel}}$. Likewise, the Tank 43H samples shown in Figure 50 and labeled with four dates spanning 1996 to 1998 are the estimated Si values corresponding to fouling of the SRS 2H-Evaporator. While these points were not included in the modeling because they were estimated Si values, these points in conjunction with the 2/2/2000 Tank $43 \mathrm{H}$ data point, do indicate the $\mathrm{NAS}_{\text {gel }}$ supersaturation region corresponding to feeds that are not processable.

This same approach can be used to develop a process control algorithm based on mixed zeolite instead of the NAS ${ }_{\text {gel }}$. However, it must be stressed that a mixed zeolite "model" would be inherently less accurate since (1) the composition of the mixed zeolite is assumed to be that of Zeolite- $\mathrm{A}\left(\mathrm{Na}_{12} \mathrm{Al}_{12} \mathrm{Si}_{12} \mathrm{O}_{48} \cdot 27 \mathrm{H}_{2} \mathrm{O}\right)$ since no analyses of this phase exist and (2) there is only one reported value of the solubility for this mixed phase at $95^{\circ} \mathrm{C}$ from Gasteiger. ${ }^{17}$ Hence, the slope of the solubility curve used, e.g. the activation energy of the dissolution, was assumed to be the same as that of NAS $_{\text {gel }}$.

The equation for the activity diagram boundary between diaspore and mixed zeolite (MZ) is given by Equation $17 \mathrm{~b}$ at $120^{\circ} \mathrm{C}$ as presented in Section 7.1 (Figure 32 and Figure 33).

$$
6 \text { Diaspore }+15 \mathrm{H}_{2} \mathrm{O}+6 \frac{\mathrm{Al}(\mathrm{OH})_{4}^{-}}{\mathrm{H}^{+}}+12 \mathrm{SiO}_{2}(\mathrm{aq})+12 \mathrm{Na}^{+} \Leftrightarrow \mathrm{MZ}
$$

This equation can be rewritten in a similar fashion to Equation [27] as:

$$
\begin{aligned}
& 6 \mathrm{AlOOH}+6 \mathrm{Al}(\mathrm{OH})_{4}^{-}+12 \mathrm{Si}(\mathrm{OH})_{4}(\mathrm{aq})+12 \mathrm{NaOH} \\
& \Leftrightarrow \mathrm{Na}_{12} \mathrm{Al}_{12} \mathrm{Si}_{12} \mathrm{O}_{48} \bullet 27 \mathrm{H}_{2} \mathrm{O}+15 \mathrm{H}_{2} \mathrm{O}+6 \mathrm{OH}^{-}
\end{aligned}
$$

Which becomes the following when the Na contribution is omitted

$$
\begin{aligned}
& 6 \mathrm{AlOOH}+6 \mathrm{Al}(\mathrm{OH})_{4}^{-}+12 \mathrm{Si}(\mathrm{OH})_{4}(a q) \\
& \Leftrightarrow A l_{12} \mathrm{Si}_{12} \mathrm{O}_{48} \bullet 27 \mathrm{H}_{2} \mathrm{O}+9 \mathrm{H}_{2} \mathrm{O}+6 \mathrm{OH}^{-}
\end{aligned}
$$


The $\mathrm{K}_{\mathrm{sp}}$ for this reaction is

$$
K_{s p}(M Z)=\frac{[\mathrm{MZ}]\left[\mathrm{OH}^{-}\right]^{6}\left[\mathrm{H}_{2} \mathrm{O}\right]^{9}}{[\mathrm{AlOOH}]^{6}\left[\mathrm{Al}(\mathrm{OH})_{4}{ }^{-}\right]^{6}\left[\mathrm{Si}(\mathrm{OH})_{4}\right]^{12}}
$$

Equation [37] can be further simplified since the $\mathrm{MZ}$ in the numerator and the water in the denominator are in their standard states and equal to 1 as shown in Equation [40]

$$
K_{s p}(M Z)=\frac{\left[\mathrm{OH}^{-}\right]^{6}}{[\mathrm{AlOOH}]^{6}\left[\mathrm{Al}(\mathrm{OH})_{4}^{-}\right]^{6}\left[\mathrm{Si}(\mathrm{OH})_{4}\right]^{12}}
$$

or in logarithmic form

$$
\begin{aligned}
& K_{s p}(\mathrm{MZ})=6 \log \left[\mathrm{OH}^{-}\right]-6 \log [\mathrm{AlOOH}]-6 \log \left[\mathrm{Al}(\mathrm{OH})_{4}{ }^{-}\right]- \\
& 12 \log \left[\mathrm{Si}(\mathrm{OH})_{4}\right]
\end{aligned}
$$

Rewriting Equation [41] in terms of the species measured in the SRS evaporator feed tanks, e.g. $\mathrm{Al}(\mathrm{M}), \mathrm{Si}(\mathrm{M}), \mathrm{OH}(\mathrm{M})$, multiplying both sides by -1 , and assuming that the $\mathrm{Al}$ from $\mathrm{AlOOH}$ exists in a aqueous form because diaspore is not kinetically favored to form in the short evaporator time frames gives the following equation:

$$
-K_{s p}(M Z)=12 \log [A l(M)]+12 \log [\operatorname{Si}(M)]-6 \log [O H(M)]
$$

which differs from Equation [35] by $2 \log [\operatorname{Si}(\mathrm{M})]$. Equation [42] would then form the basis for the relation of measured molar feed tank solutions at $25^{\circ} \mathrm{C}$ to the activity diagrams for mixed zeolite (MZ) and to the calculated $\mathrm{Q} / \mathrm{K}$ at $120^{\circ} \mathrm{C}$ with $40 \%$ evaporation. Regressing the tank data from Table IV, Table V, Table IX and Table X in this study and Tables III and IV in Part I against the Q/K values in Table XIII-Table XVI in this study and Table VII in Part I gives the following correlation for the 101 points:

$$
\begin{aligned}
& \log (Q / K)_{M Z 120^{\circ} \mathrm{C} / 40 \% \text { evap }}=39.62+1.04(12 \log [A l(M)]+12 \log [\operatorname{Si}(M)] \\
& -6 \log [O H(M)]
\end{aligned}
$$

with an $\mathrm{R}^{2}$ of 0.95 and a RMS error of 1.59 . Regression with the Na term present for the 32 data points, gave no correlation at all.

Therefore, either the simplified mechanistic model relating $\log \mathrm{Q} / \mathrm{K}_{(\mathrm{NAS})}$ at $120 / 140^{\circ} \mathrm{C}$ and $40 \%$ evaporation (Equation 36) or $\log \mathrm{Q} / \mathrm{K}_{(\mathrm{MZ})}$ at $120 / 140^{\circ} \mathrm{C}$ and $40 \%$ evaporation (Equation 43) could be related to operational history and be used as a process control model for the SRS evaporators. However, the solubility of the mixed zeolite phase was estimated from data at only one temperature, $95^{\circ} \mathrm{C}$, and the formation constant was approximated as a weighted average of the formation constants of $\mathrm{NAS}_{\text {gel }}$ and Zeolite-A (see Appendix B). Better solubility data was available for the $\operatorname{NAS}_{\mathrm{gel}}$ (Appendix B) and, therefore, Equation 36, which is based on this solubility, is recommended for implementation to control the SRS evaporators. In addition, the $\mathrm{NAS}_{\text {gel }}$ phase is the 


\section{WSRC-TR-2000-00293, Rev. 1}

incipient phase, which forms and needs to be controlled. The NAS $\mathrm{gel}_{\text {get }}$ activity diagrams are also in better agreement with all available operating history from the SRS $2 \mathrm{H}, 3 \mathrm{H}$, and 2F-Evaporator systems than the corresponding activity diagrams with mixed zeolite. Thus the simplified mechanistic model (Equation 36) accounts for all SRS evaporator operating history and is the easiest to implement in that an additional analysis for $\mathrm{Na}$ is not required. 


\section{WSRC-TR-2000-00293, Rev. 1}

\subsection{CONCLUSIONS}

- Thermodynamic modeling, in the form of steady state activity diagram representation, confirms tank chemistry conditions that produced aluminosilicate phases such as nitrated sodalite/nitrated cancrinite $\left(\mathrm{Na}_{8} \mathrm{Al}_{6} \mathrm{Si}_{6} \mathrm{O}_{24}\left(\mathrm{NO}_{3}\right)_{2} \bullet 4 \mathrm{H}_{2} \mathrm{O}\right)$ and sodium diuranate $\left(\mathrm{Na}_{2} \mathrm{U}_{2} \mathrm{O}_{7}\right)$ in the SRS 2H-Evaporator

- Modeling was performed with a commercially available software package, The Geochemist's Workbench (GWB)

- GWB uses the Lawrence Livermore National Laboratoty (LLNL) extensive thermodynamic database being used to model High Level Waste (HLW) form performance in a geologic repository

- The GWB database contains many radioactive and metastable phases and gels (hydrogels) which are pertinent to the relatively short kinetic regimes during which the evaporator deposits form

- The GWB database was augmented with solubility data for $\mathrm{NaAlO}_{4}$, $\mathrm{Al}(\mathrm{OH})_{3}$, AlOOH developed at Hanford; Zeolite-A and a sodium aluminosilicate gel $\left(N A S_{g e l}\right)$ known to form in evaporators used for processing aluminum ore via the Bayer process; "mixed zeolite" (a partially crystallized mixture of $N A S_{g e l}+$ Zeolite-A + cancrinite formed in evaporators used to process pulp and paper via the Kraft process; hydroxysodalite data generated in support of the Kraft pulp and paper process; and $\mathrm{NaNO}_{3}$.

-- the solubility data for these phases were a strong function of $\mathrm{NaOH}$ concentration

-- solubility as a function of temperature was entered into the database at a reference 8 molal $\mathrm{Na}$ concentration pertinent to the concentration of $\mathrm{Na}$ in evaporator feeds

- $\quad$ The GWB uses the Helgeson $B^{\cdot}(b$-dot) method to estimate activity coefficients for the conversion of molar feed tank compositions to molal concentrations used in the calculations

- Feed and drop tank data measured at $25^{\circ} \mathrm{C}$ were modeled at the elevated evaporator operating temperature of $120^{\circ} \mathrm{C}$

- Simulated $40 \%$ evaporations were performed by basing the calculations on 600 grams of water instead of the default of 1 kilogram of water

- Code validation in this complex $\mathrm{Na}-\mathrm{N}-\mathrm{Si}-\mathrm{Al}-\mathrm{U}-\mathrm{H}_{2} \mathrm{O}$ system was performed by modeling data from SRS M-Area waste tanks and from experiments performed in uranyl nitrate solutions titrated with strong caustic ( $\mathrm{NaOH})$ 


\section{WSRC-TR-2000-00293, Rev. 1}

- The quality of the available analytic data for the evaporator feed and drop tanks was found to be problematic during thermodynamic modeling

- Chemical data was often incomplete

- Data for Si was most often missing

- F-Area laboratory data for Si was always biased high by $2 X$ when the concentrations of Si in the undiluted sample are in the 30-55 ppm range or $>3 X$ when the concentrations are $<30 \mathrm{ppm}$

-- a routine dilution of $120 X$ for measurement of tank solutions puts the analytic solutions below the detection limit for $\mathrm{Si}$

- $\quad$ The Si analyses from SRTC are more accurate than the F-Area laboratory analyses

- One of the two methods currently being used for Si analyses at SRTC need to be implemented in F-Area laboratory

- A mass balance was performed on every feed tank composition before it was entered into GWB and missing data for elements other than Si and Al estimated by samples that bracketed the missing values

- Thermodynamic modeling focused on the formation of the sodium aluminosilicate hydrogel, hereafter referred to as $\mathrm{NAS}_{\mathrm{gel}}$, since this was the kinetically most rapid step in the formation of nitrated sodalite/cancrinite via sequential densification (aging) of $\mathrm{NAS}_{\mathrm{gel}} \rightarrow$ Zeolite-A(cubic) $\rightarrow$ sodalite(cubic) $\rightarrow$ cancrinite (hexagonal)

- The sequential transformations require the saturation of the evaporator and/or tank solutions with respect to the parent $N A S_{\text {gel }}$ phase.

- NAS hydrogels form from reactive oxides, soluble silicates, and soluble aluminates in a caustic solution when the solution stoichiometry of the constituent aluminate and silicate species is $\sim 1: 1$

- $\quad$ The hydrogel converts to Zeolite- $A\left(\mathrm{Na}_{12} \mathrm{Al}_{12} \mathrm{Si}_{12} \mathrm{O}_{48} \bullet 27 \mathrm{H}_{2} \mathrm{O}\right)$ under hydrothermal conditions at elevated temperature such as the conditions existing in the SRS evaporators

- Wilmarth demonstrated that the nitrated-cancrinite/sodalite forming in the SRS 2H-Evaporator forms from Zeolite-A

- Zeolite-A and hydroxysodalite $\left(\mathrm{Na}_{8}\left[\mathrm{Al}_{6} \mathrm{Si}_{6} \mathrm{O}_{24}\right](\mathrm{OH})_{2} \bullet 1.5 \mathrm{H}_{2} \mathrm{O}\right)$ formation from a gel phase has also been observed in evaporators used in the wood pulp industry

- Zeolite $-\mathrm{A} \rightarrow$ sodalite $\rightarrow$ cancrinite $\left(\left(\mathrm{Na}_{7.6} \mathrm{Al}_{6} \mathrm{Si}_{6} \mathrm{O}_{24}\left(\mathrm{CO}_{3}\right)_{1.6} \bullet 2.1 \mathrm{H}_{2} \mathrm{O}\right)\right.$ formation from a gel phase has also been observed in Bayer aluminum processing. 


\section{WSRC-TR-2000-00293, Rev. 1}

- Modeling the denser aged phases, which are less soluble than the NAS ${ }_{\text {gel }}$ could unnecessarily constrict the solution chemistry range of the SRS evaporators.

- Variable Depth Sample (VDS) analyses discussed in this report and in Part $\mathrm{II}^{3}$ have shown that the feed tanks for the SRS $2 \mathrm{H}$ and $3 \mathrm{H}$-Evaporators are stratified with respect to $\mathrm{Si}, \mathrm{Fe}$, and $\mathrm{U}$

- A layer enriched in $\mathrm{Si}, \mathrm{Fe}$, and $U$ exists above the sludge that is dense and turbid

- The dense layer is defined as the "Zone of Turbidity" or ZOT in this study

- $\quad$ The ZOT does not settle well

--stratification was present in VDS samples from the SRS 2H-Evaporator feed tank taken in January and February 2000 after six weeks of settling --stratification was present in the VDS samples for the SRS $2 \mathrm{H}$ -

Evaporator taken again in October 2000 after several months of settling

- $\quad$ The ZOT is likely enriched in silica colloids which are negatively charged and repel each other (hydrophobic) prohibiting the material from settling

- $\quad$ The VDS sample data in this report and the data for the SRS $3 H$ Evaporator in Part II indicate that the ZOT is 20-24" thick

- The depth of the ZOT was confirmed to be 22 " by turbidity measurements taken in March 2001

- The SRS 2H operational history can be explained in terms of four different time populations based on operational records of the amount of $\mathrm{Si}(\mathrm{kgs})$ and $\mathrm{Al}(\mathrm{kgs})$ sent to Tank $43 \mathrm{H}$ from DWPF and H-Canyon:

- High Si, low Al processing characterized by frequent large DWPF Slurry Mix Evaporator (SME) carryovers enriched in Si-containing frit (January 1996-June 1997)

- Moderate Si, low Al processing characterized by few SME carryovers, some without frit and little Al from H-Canyon (August 1997-March 1998)

- Moderate Al, moderate Si processing characterized by no SME carryovers and moderate Al from H-Canyon (April 1998-December 1998)

- High Al, moderate Si processing characterized by no SME carryovers, high Al from H-Canyon (December 1998-October 1999).

- The initial fouling of the SRS 2H-Evaporator with aluminosilicates was observed during the High $\mathrm{Si}$, low $\mathrm{Al}$ processing time regime 


\section{WSRC-TR-2000-00293, Rev. 1}

- Initial scaling was observed in April 1997 and the GDL plugged in August 1997

- The feed pump was in close proximity to the silica enriched ZOT at 64" until June 1997

- The DWPF recycle stream was overly enriched in silica due to uncontrolled SME carryovers

- $\quad$ The activity diagram modeling shows that the evaporator feeds were saturated with respect to the $\mathrm{NAS}_{\text {gel }}$ phase and $\mathrm{Na}_{2} \mathrm{U}_{2} \mathrm{O}_{7}$

- Zeolite seed material had been fed to the evaporator prior to the SME carryovers in the form of silica rich HEME/HEPA digest residues from a large scale dissolution demonstration performed at SRTC

- Acceptable operation of the SRS 2H-Evaporator occurred during the moderate $\mathrm{Si}$, low Al time regime

- A new feed pump had been installed at 100”, well above the silica enriched ZOT

- The DWPF recycle stream contained only a few SME carryovers and several of them did not contain glass forming frit

- $\quad$ The activity diagram modeling shows that the evaporator feeds were not saturated with resepct to the $N A S_{\text {gel }}$ phase but were saturated with respect to $\mathrm{Na}_{2} \mathrm{U}_{2} \mathrm{O}_{7}$

- The second period of fouling of the SRS 2H-Evaporator was initiated during the moderate $\mathrm{Si}$, moderate $\mathrm{Al}$ time regime

- The GDL plugged for the second time and deposits were noted on the coils and walls only 2 months after this time regime began

- The feed pump remained at 100”, well above the silica enriched ZOT

- $\quad$ The DWPF recycle stream contained no SME carryovers

- H-Canyon started to send wastes moderately high in Al

- $\quad$ The activity diagram modeling shows that the evaporator feeds were initially unsaturated with resepct to the $N A S_{\text {gel }}$ phase but became saturated with respect to this phase as the Al concentration in the feed increased; the evaporator solutions were saturated with respect to $\mathrm{Na}_{2} \mathrm{U}_{2} \mathrm{O}_{7}$ during the moderate Al time regime 


\section{WSRC-TR-2000-00293, Rev. 1}

- The second period of fouling of the SRS 2H-Evaporator progressively worsened during the moderate $\mathrm{Si}$, high $\mathrm{Al}$ time regime

- Significant deposits were observed on all internal surfaces of the evaporator during this time regime

- $\quad$ The feed pump remained at 100", well above the silica enriched ZOT

- $\quad$ The DWPF recycle stream contained no SME carryovers

- $\quad H$-Canyon started to send wastes extremely high in Al

- $\quad$ The activity diagram modeling shows that the evaporator feeds were saturated with respect to the $\mathrm{NAS}_{\text {gel }}$ phase and $\mathrm{Na}_{2} \mathrm{U}_{2} \mathrm{O}_{7}$

- Activity diagram modeling of the SRS 2F-Evaporator using SRTC Si analyses indicates that the SRS 2F-Evaporator system is not saturated with respect to aluminosilicate formation

- Comparison of historic chemical data from the SRS 3H Evaporator feed tanks from 1992 to recent (post 1997) indicates that more Si rich feeds may be being fed to these systems now; this is not supported by the data for the SRS $3 \mathrm{H}$ drop tank nor the other evaporator systems. Potential causes for these trends include the following:

- Bad analytic data for Si in 1992 for the SRS $3 H$ Evaporator feed tanks

- Waste is no longer stored for a year before being processed

-- if Si had been present it would have had a chance to settle

- Alternating drop tanks, one active and one passive, are no longer used

-- if Si had been present it would have had a chance to settle

- Inter-area transfers and more co-mingling of wastes of different chemistry

- $\quad$ Sludge washing (soluble Si from the sludge)

- The GWB model indicates that the $\mathrm{NAS}_{\text {gel }}$ may precipitates via a reaction with gibbsite, $\mathrm{Al}(\mathrm{OH})_{3}$, which may be present as a gel or poorly crystallized because the kinetics of gibbsite formation are slow compared to the kinetics of the $\mathrm{NAS}_{\text {gel. }}$

- The equilibrium boundary that separates tank solutions that precipitate aluminosilicates from those that do not is the boundary between crystalline $\mathrm{Al}(\mathrm{OH})_{3}$ and $\mathrm{NAS}$ gel at the tank temperatures and between diaspore, $\mathrm{AlOOH}$, and $\mathrm{NAS}_{\text {gel }}$ at the evaporator temperatures 


\section{WSRC-TR-2000-00293, Rev. 1}

- The presence of an amorphous aluminate phase, perhaps a $\mathrm{Al}(\mathrm{OH})_{3}$ gel, is substantiated by the mass balance calculations of the analysis performed on the SRS 2H-Evaporator wall and pot samples which contain excess Al over Si that is $x$-ray amorphous

- $\quad$ The mechanisms of formation of the $N A S_{\text {gel }}$ via an aluminate precursor which adheres to the tank walls is similar to the findings of crystalline gibbsite adhering to the walls of the M-area waste tanks.

- Thermodynamic modeling using GWB was used to calculate the supersaturation index, $\log \mathrm{Q} / \mathrm{K}$, for the $\mathrm{SRS} 2 \mathrm{H}$ and $2 \mathrm{~F}$-Evaporator systems (this study) as well as for the SRS 3H-Evaporator system (Part II ${ }^{3}$ ).

- $Q$ is the reaction quotient and $K$ is the solubility product

- $\quad$ The feed and drop tank $Q / K$ ratios for the SRS $2 H, 2 F$ and $3 H$-Evaporator systems were modeled at the respective evaporator operating temperatures of $120^{\circ} \mathrm{C}$ and $140^{\circ} \mathrm{C}$ with and without a simulated $40 \%$ evaporation

- $\quad$ Negative log $Q / K$ indicates undersaturation with respect to the $N A S_{\text {gel }}$ while positive values indicate supersaturation

- A mechanistic process control algorithm was developed based on the log $\mathrm{Q} / \mathrm{K}$ calculations to use as a tool to "qualify" feeds for the SRS evaporators and prevent aluminosilicate deposition

- The saturation index at the elevated evaporator temperature with a simulated $40 \%$ evaporation was regressed versus measured tank chemistries measured at $25^{\circ} \mathrm{C}$ such as $\log [\mathrm{Si}(\mathrm{M})], \log [\mathrm{Al}(\mathrm{M})], \log [\mathrm{OH}(\mathrm{M})], \log [\mathrm{Na}(\mathrm{M})]$

- $\quad$ The mechanism modeled is the equilibrium equation for the boundary on the activity diagrams between diaspore and $N A S_{\text {gel }}$, e.g.

$$
\begin{aligned}
& 6 \mathrm{AlOOH}+6 \mathrm{Al}(\mathrm{OH})_{4}^{-}+14 \mathrm{Si}(\mathrm{OH})_{4}(\mathrm{aq})+12 \mathrm{NaOH} \Leftrightarrow \\
& \mathrm{Na}_{12} \mathrm{Al}_{12} \mathrm{Si}_{14} \mathrm{O}_{52} \bullet 31 \mathrm{H}_{2} \mathrm{O}+15 \mathrm{H}_{2} \mathrm{O}+6 \mathrm{OH}^{-}
\end{aligned}
$$

- $\quad$ Since the Na is not routinely measured in the tank farm, more data was available to model a simplified model without $\mathrm{Na}$ as $\mathrm{NaOH}$, which represents the formation of the aluminosilicate "cage" structure of the $N A S_{g e l}$ and its subsequent crystallization products, e.g.

$$
\begin{aligned}
& 6 \mathrm{AlOOH}+6 \mathrm{Al}(\mathrm{OH})_{4}^{-}+14 \mathrm{Si}(\mathrm{OH})_{4}(\mathrm{aq}) \Leftrightarrow \\
& \mathrm{Al}_{12} \mathrm{Si}_{14} \mathrm{O}_{46} \bullet 31 \mathrm{H}_{2} \mathrm{O}+9 \mathrm{H}_{2} \mathrm{O}+6 \mathrm{OH}^{-}
\end{aligned}
$$

- The simplified mechanistic model with an $R^{2}$ of 0.90 takes the form: 
WSRC-TR-2000-00293, Rev. 1

$$
\begin{aligned}
& \log (\mathrm{Q} / \mathrm{K})_{120^{\circ} \mathrm{C} / 40 \% \text { evap }}=37.2404+0.9933(12 \log [\mathrm{Al}(\mathrm{M})]+14 \log [\mathrm{Si}(\mathrm{M})] \\
& -6 \log [\mathrm{OH}(\mathrm{M})]
\end{aligned}
$$

where the terms on the RHS are the measured molar tank concentrations at $25^{\circ} \mathrm{C}$.

- Use of the simplified mechanistic model has already shown that the solubility product criteria, [Al]*[Si] in $\mathrm{M}^{2}$ recently used to qualify feeds for the SRS $3 \mathrm{H}-$ Evaporator is overly conservative based on operational history of the SRS 2FEvaporator feeds

\subsection{RECOMMENDATIONS}

The following recommendations from this study should be evaluated for implementation as soon as feasible. The recommendations are grouped into the following subgroups: physical/mechanical, analytic, and evaporator model validation and implementation recommendations.

\section{Physical/Chemical Recommendations}

- Feed pumps for the SRS evaporators should be maintained at $>20$ " above the "Zone of Turbidity" which is 40" above the sludge layer based on the depth populations defined in this study, in Part $\mathrm{II}^{3}$, and the turbidity measurements made in March 2001

- Drop tank transfer jets should be maintained at positions above the salt layer to avoid recycling any precipitated $\mathrm{Fe}(\mathrm{OH})_{3}$ and/or silica sol deposits, and/or entrained sludge solids back to the feed tank

- As silica rich feeds can supersaturate >200\%, this will allow any supersaturation of the silica rich solids to precipitate in the cooler temperature environment of the drop tank thus taking advantage of the decreasing solubility of these phases with temperature

- If possible, the evaporator should not be fed within 5-6 hours of tank transfers and/or recent tank recycles

- A longer term strategy for the SRS 2H-Evaporator system would be recycle to a pre-feed tank to allow any silica-rich phases time to settle out or use a strategy like that used in the 2F-Evaporator where fresh feed is stored in a prefeed tank while recycle goes directly back to the feed tank

\section{Analytic Recommendations}


- Routine analytic samples, if used for modeling, should be taken at the height of the feed pump

- Analytic samples should not be taken within 5-6 hours of tank transfers and/or recent tank recycles

- A more accurate Si analysis method must be implemented in the F-Area laboratory immediately

- A minimum of three wet chemical analyses need to be made on any sample pulled from the evaporator feed tanks in order to achieve better statistical confidence.

- Basing a statistical analysis on one replicate of one sample taken every three months is inadequate for achieving high confidence levels in process control.

\section{Model Validation and Implementation Recommendations}

- The process model given in Equation [36] for operation of the SRS 2HEvaporator must be validated by SRTC using laboratory data being developed at the Pacific Northwest National Laboratory (PNNL) or at Oak Ridge National Laboratory (ORNL)

- Implementation of the process model for operation of the SRS 2H-Evaporator given in Equation [36] must include a sensitivity (range of applicability) analysis in order to assure that the evaporator will not process any feeds that are outside the range for which the model was developed. This will be evaluated in Part III. ${ }^{74}$

- Implementation of the process model for operation of the SRS 2H-Evaporator given in Equation [36] should include incorporation of the various sources of error (model error, analytic error, concentration error, tank transfer errors, etc.) so that the level of confidence desired can be guaranteed by the final operating envelope.

- The desired confidence level for the prevention of aluminosilicate deposition must be considered by the tank farm, e.g. $>95 \%, 95 \%, 90 \%$, in order to implement the process model.

\subsection{ACKNOWLEDGEMENTS}

Dr. W. J. Frederick of the Institute of Paper Science and Technology is gratefully acknowledged for the usage of his unpublished data on the solubility of hydroxysodalite and Zeolite-A. 


\section{WSRC-TR-2000-00293, Rev. 1}

Kent Gilbreath from the SRS H-Area Tank farm is thanked for providing the data about sludge levels, feed pump levels, and operating temperatures of the SRS $3 \mathrm{H}$ from the Tank Farm morning reports. Ken Jones of the F-Area laboratory is acknowledged for discussions about the F-Area $\mathrm{Si}$ analytic methodology and dilution factors.

Many helpful suggestions and discussions with Jeff Pike of SRS are acknowledged. Most notable of his many contributions was assistance in gathering the solubility data for $\mathrm{NaAlO}_{2}$ and $\mathrm{AlO}_{2}^{-2}$ so that these species could be adequately represented on the activity diagrams.

This work was performed under contract No. DE-AC09-96SR18500 with the Department of Energy and co-funded by the Tank Focus Area under Technical Task Plan \# SR-1-9WT-31. 


\subsection{REFERENCES}

1 W. R. Wilmarth, C. J. Coleman, A. R. Jurgensen, W. M. Smith, J. C. Hart, W. T. Boyce, D. Missimer, C. M. Conley, "Characterization and Dissolution Studies of Samples from the 242-16H Evaporator," WSRC-TR-2000-00038, Rev. 0 (January 31, 2000).

2 W. R. Wilmarth, C. J. Coleman, J. C. Hart, and W. T. Boyce, "Characterization of Samples from the 242-16H Evaporator Wall," WSRC-TR-2000-00089 (March 20, 2000).

3 C.M. Jantzen, J.E. Laurinat, and K.G. Brown "Thermodynamic Modeling of the SRS Evaporators: Part II. The 3H Systems (U),' WSRC-TR-2001-00155, Rev. 1 (April, 2002).

4 W. R. Wilmarth, S. D. Fink, D. T. Hobbs, M. S. Hay, "Characterization and Dissolution Studies of Samples from the 242-16H Evaporator Gravity Drain Line," WSRC-TR-97-00326, Rev.0 (October 16, 1997).

$5 \quad$ R.M. Garrels, “Geology,” Section 6 in Atllas of Electrocemical Equilibria in Aqueous Solutions, National Association of Corrosion Engineers, Houston, TX, (English Translation), 89-94 (1966).

6 T. S. Bowers, K. J. Jackson, and H. C. Helgeson, "Equilibrium Activity Diagrams for Coexisting Minerals and Aqueous Solutions at Pressures and Temperatures to $5 \mathbf{k b}$ and $\mathbf{6 0 0}^{\circ} \mathbf{C}$," Springer-Verlag, New York, 397pp. (1984).

$7 \quad$ R. M. Garrels and C. L. Christ, "Solutions, Minerals, and Equilibria," Harper \& Row, New York, 450pp. (1965).

8 K. V. Ragnarsdottir, "Dissolution Kinetics of Heulandite at pH 2-12 and $\mathbf{2 5}^{\circ}$ C," Geochimica et Cosmochimica Acta, 57, 2439-2449 (1993).

9 T. S. Bowers and R. G. Burns, "Activity Diagrams for Clinoptilolite: Susceptibility of this Zeolite toFurther Diagenetic Reactions," American Mineralogist, 75, 601-619 (1990).

10 C. M. Jantzen and J.B. Pickett, "Vitrification of M-Area Mixed (Hazardous and Radioactive) Wastes: I. Sludge and Supernate Characterization," WSRC-TR-94-0234 (September, 2001). Earlier report with fewer tank analyses published as DPST-89-351 (March 1, 1989).

11 R. Pierce, WSRC-NB-2000-00054 (June 14, 2000). 
12 E.S. Dana, “A Textbook of Mineralogy,” John Wiley \& Sons, Inc., New York, 851pp (1932).

13 W. A. Deer, R. A. Howie, and J. Zussman, "Rock-Forming Minerals, Vol IV," John Wiley \& Sons, Inc., New York, 435pp. (1963).

14 W. Sinkler, T.P. O’Holleran, S.M. Frank, M.K. Richmann, S.G. Johnson, "Characterization of A Glass-Bonded Ceramic Waste Form Loaded with U and Pu," Scientific Basis for Nuclear Waste Management, XXIII, R.W. Smith and D.W. Shoesmith (Eds.), Materials Research Society, Pittsburgh, PA, 423-429 (2000) and T. Moschetti, W. Sinkler, T. Disanto, M.H. Hois, A.R. Warren, D. Cummings, S.G. Johnson, K.M. Goff, K.J. Bateman, S.M. Frank,

"Characterization of a Ceramic Waste Form Encapsulating Radioactive Electrorefiner Salt," Scientific Basis for Nuclear Waste Management, XXIII, R.W. Smith and D.W. Shoesmith (Eds.), Materials Research Society, Pittsburgh, PA, 577-582 (2000).

15 Wilmarth, personnel communication

16 W.J. Frederick, personal communication

17 H. A. Gasteiger, W. J. Frederick, and R. C. Streisel, "Solubility of Aluminosilicates in Alkaline Solutions and a Thermodynamic Equilibrium Model," Ind. Eng. Chem. Res., 31, 1183-1190 (1992).

18 Kirk-Othmer Encyclopedia of Chemistry, Vol. 16 (1995).

19 R. M. Barrer, J. W. Baynham, F. W. Bultitude, and W. M. Meier, "Hydrothermal Chemistry of the Silicates. Part V23I, Low-Temperature Crystal Growth of Aluminosilicates, and of Some Gallium and Germanium Analogues," 195-208 (1959).

20 R. M. Milton, U.S. Patents \#2,882,243 and \#2,882,244 (1959)

21 R.M. Barrer, "Hydrothermal Chemistry of Zeolites," Academic Press,London (1982).

22 T. Ejaz A.G. Jones and P. Graham, "Solubility of Zeolite-A and Its Amorphous Precursor Under Synthesis Conditions,” J. Chem. Eng. Data, 44, 574-576 (1999).

23 The American Heritage Dictionary, Second College Edition, Houghton Mifflin Co., Boston, MA, (1982). 
24 G.M. Barrow, "Physical Chemistry," 2nd edition, McGraw-Hill Book Company, New York, 843pp., (1966).

25 M.C. Barnes, J.A. Mensah, and A.R. Gerson, "The Mechanism of the Sodaliteto-Cancrinite Phase Transformation in Synthetic Spent Bayer Liquor," Microporous and Mesoporous Materials, 31, 287-302 (1999).

26 A.R. Gerson and K. Zheng, "Bayer Process Plant Scale: Transformation of Sodalite to Cancrinite," J. of Crystal Growth, 171, 209-218 (1997).

27 J.C. Buh. And J. Lons, "Synthesis and Crystal Structure of Nitrate Enclathrated Sodalite, $\mathrm{Na}_{8}\left[\mathrm{AlSiO}_{4}\right]_{6}\left(\mathrm{NO}_{3}\right)_{2}$," Journal of Alloys and Compounds, v.235, 41-47 (1996).

28 W. R. Wilmarth, D. D. Walker, S. D. Fink, "Sodium Aluminosilicate Formation in Tank 43H Simulants,” WSRC-TR-97-00389, Rev. 0 (November 15, 1997).

29 B. Subotic, D. Skrtic, I. Smit, L. Sekovanic, "Transformation of Zeolite-A into Hydroxysodalite," J. Crystal Growth, 50, 498-508 (1980).

30 S. Bosnar and B. Subotic, "Mechanism and Kinetics of the Growth of Zeolite Microcrystals; Part I. Influence of the Alkalinity of the System on the Growth of Zeolite-A Microcrystals," Microporous and Misoporous Materials, 28, 483-493 (1999).

31 D. W. Breck, W. G. Eversole, R. M. Milton, T. B. Reed, and T. L. Thomas, “Crystalline Zeolitesl I. The Properties of a New Synthetic Zeolite, Type A," J. Am. Chem. Soc., 78 [23], 5963-5971 (1956).

32 J. Maly and V. Vesely, “A Contribution to Sodium Polyuranate Chemistry,” J. Inorg. Nucl. Chem., 7, 119-128 (1958).

33 J. E. Ricci and F. J. Loprest, "Phase Relations in the System Sodium OxideUranium Trioxide-Water at 50 and $7^{\circ}{ }^{\circ}$ C," J. Am. Chem. Soc., 77, 2119-2129 (1955).

34 C. A. Wamser, J. Belle, E. Bernsohn and B. Williamson, "The Constitution of the Uranates of Sodium,” J. Am. Chem. Soc, 74, 1020-1022 (1952).

35 D. T. Hobbs and D. G. Karraker, "Recent Results on the Solubility of Uranium and Plutonium in Savannah River Site Waste Supernate," Nuclear Technology, 114, 318-324 (1996).

36 W.R. Wilmarth and R.A. Peterson, "Analyses of Surface and Variable Depth Samples from Tanks 30H and 32H,” WSRC-TR-2000-00112 (April 2000). 
37 W.R. Wilmarth, J.T. Mills, V.H. Dukes, C.J. Coleman, J.C. Hart, W.T. Boyce, and R.L. Cadle, "Characterization of Samples from the 3H-Evaporator System Including Effects of Recycle,” WSRC-TR-2000-00399 (October, 2000).

38 W.R. Wilmarth, “Tank 30H Sample Analysis Results," SRT-LWP-2000-00191 (January 10, 2001).

39 C. M. Jantzen, Standard Practice/Guide for Characterization of Radioactive and/or Hazardous Wastes for Thermal Treatment (ASTM Standard ballotted 2001).

40 R. G. Breuer, L. R. Barsotti, and A. C. Kelly, "Extractive Metallurgy of Aluminum. I. Alumina,” Wiley Interscience, New York, 163pp. (1963).

41 G. A. Parks, “Aqueous Surface Chemistry of Oxides and Complex Oxide Minerals," in Equilibrium Concepts in Natural Water Systems, Adv. In Chemistry Series 67, R. F. Gould (Ed.), Am. Chem. Soc. Publ., Washington, DC, 121-160 (1967).

42 D. Langmuir, “Aqueous Environmental Geochemistry,” Prentice Hall, Upper Saddle River, New Jersey, 600pp. (1997).

43 B. C. Bunker and G. W. Arnold, "The Effect of Solution pH and Ion Concentrations on Leaching of Silicate Glass," Sci. Basis for Nuclear Waste Management, Vol. VI, (D. G. Brookins, Ed.), 151-158 (1983)

44 L. Maya, "Sorbed Uranium (VI) Species on Hydrous Titania, Zirconia, and Silica Gel,” Radiochimica Acta, v.51, 147-151 (1982).

45 J.A. Davis, "Surface Complexation Modeling of Uranium (VI) Adsorption on Natural Mineral Assemblages," U.S. Nuclear Regulatory Commission, NUREG/CR-6708 (March, 2001).

46 J. B. Pickett and C. M. Jantzen, “Tank Inspections and Chemical Analyses to Support a Case-By-Case “Contained-In" Determination for the M-Area VTF Tanks,” U.S. DOE Report F18-ENG-99-0012 (March 3, 1999).

47 J. I. Drever, “The Geochemistry of Natural Waters," Prentice Hall Publishers, Upper Saddle River, NJ, $3^{\text {rd }}$ Edition, 436 pp. (1997).

48 C.E. Harvie, N. Møller and J.H. Weare, "The prediction of mineral solubilities in Natural Waters: The Na-K-Mg-Ca-H-SO $-\mathrm{OH}-\mathrm{HCO}_{3}-\mathrm{CO}_{3}-\mathrm{CO}_{2}-\mathrm{H}_{2} \mathrm{O}$ System to High Ionic Strengths at $25^{\circ}$ C,' Geochimica et Cosmochimica Acta, 48, 723-751 (1984). 
49 H. C. Helgeson, "Thermodynamics of Hydrothermal Systems at Elevated Temperatures and Pressures,” Am. J. Sci., 267, 729-804 (1969).

$50 \quad$ K. S. Pitzer and L. Brewer, "Thermodynamics, $2^{\text {nd }}$ Edition of Revision of Thermodynamics" in G. N. Lewis and M. Randall, McGraw-Hill, New York, 723pp. (1961).

51 W. R. Wilmarth, D. D. Walker, S. D. Fink, "Sodium Aluminosilicate Formation in Tank 43H Simulants," WSRC-TR-97-00389, Rev. 0 (November 15, 1997).

52 A.J. Mattus, C.H. Mattus, and R.D. Hunt, "Kinetic Testing of Nitrate-Based Sodalite Formation Over the Temperature Range of 40 to $100^{\circ}$ C," U.S. DOE Report ORNL/TM-2001, Oak Ridge National Laboratory, UT-Battelle, LLC, Oak Ridge, TN (April 13, 2001).

53 C. A. Wamser, J. Belle, E. Bernsohn and B. Williamson, "The Constitution of the Uranates of Sodium,” J. Am. Chem. Soc, 74, 1020-1022 (1952).

54 A.A. Frost and R.G. Pearson, "Kinetics and Mechanism," $2^{\text {nd }}$ Edition, John Wiley \& Sons, New York, 405pp. (1953).

55 H. Bui, "Characterization of H-Canyon HLW Sludge Generated During the Post-Reactor Period,” WSRC-TR-99-00298, Rev. 1 (March 26, 2001).

56 Jantzen, C.M., "Summary and Status of HEME/HEPA Filter Dissolution for DWPF (Technology Issue 10.1),” U.S. DOE Report WSRC-RP-89-533 (1989); U.S. Patent \#5,686,365 Method for Dissolution and Stabilization of Silica-Rich Fibers (November 1997).

57 W.R. Wilmarth and R.A. Peterson, “Analyses of Surface and Variable Depth Samples from Tank 43H,” WSRC-TR-2000-00208 (May 31, 2000).

58 D.D. Walker and C.J. Coleman, "Densities and Weight\% Solids of Simulated Salt Solutions," WSRC-TR-91-176 (April 1991).

59 W.R.Wilmarth, “Analyses of Surface and Variable Depth Samples from Tank 43H,” WSRC-TR-2001-00073 (March 29, 2001).

60 C. Coleman, personal communication

61 R.K. Iler, “The Colloid Chemistry of Silica and Silicates," Cornell University Press, Ithaca, NY, 324pp. (1955).

62 A.K. Varshneya, "Fundamentals of Inorganic Glasses," Academic Press, Inc., New York, 570pp. (1994). 
63 C.F. Baes, Jr. and R.E. Mesmer, "The Hydrolysis of Cations," John Wiley \& Sons, New York, 489pp. (1976).

64 S. Sjoberg, L.Ohman, N. Ingri, "Equilibrium and Structural Studies of Silicon(IV) and Aluminum(III) in Aqueous Solution. 11. Polysilicate Formation in Alkaline Aqueous Solution. A Combined Potentiometric and 29Si NMR Study," Acta Chemica Scandinavica, A39, 93-107 (1985).

65 I. Grenthe, et. al., "Chemical Thermodynamics of Uranium," North Holland, New York (1992).

66 R.H. Busey, R.E. Mesmer, "Inoization Equilibria of Silicic Acid and Polysilicate Formation in Aqueous Sodium Chloride Solutions to $300^{\circ}$ C," Inorg. Chem., 16, 2444-2450 (1977).

67 A.S. Russell, J.D. Edwards, and C.S. Taylor, "Solubility and Density of Hydrated Aluminas in NaOH Solutions," J. of Metals, p.1123-1128 (October, 1955).

68 D.A. Reynolds and D.L. Herting, "Solubilities of Sodium Nitrate, Sodium Nitrite, and Sodium Aluminate in Simulated Nuclear Waste," U.S. DOE Report, RHO-RE-SST-14P, Rockwell Hanford Operations, Richland, WA (1984).

69 H. Park and P. Englezos, "Thermodynamic Modeling of Sodium Aluminosilicate Formation in Aqueous Alkaline Solutions," Ind. Eng. Chem. Res., 38, 4959-4965 (1999).

70 M. C. Thompson, Savannah River Technology Center, personnel communication.

71 R.F. Swingle, II, "Report on Corrosion Chemistry Analyses for Tanks 26F, 46F, 33F and 29H - December, 1998," WSRC-TR-00049, Rev. 1 (April 23, 1999).

72 S.M. Budd, "The Mechanisms of Chemical Reaction Between Silicate Glass and Attacking Agents,” Phys. Chem. Glasses, 2[4], 111-114 (1961).

73 S.V. Mattigod and B.P. McGrail, "Estimating the Standard Free Energy of Formation of Zeolites Using the Polymer Model," Microporous and Mesoporous Materials, 27, 41-47 (1999).

74 C.M. Jantzen, J.E. Laurinat, T.B. Edwards, and K.G. Brown, “Thermodynamic Modeling of the SRS Evaporators: Part III. Process Control Strategy, Higher Temperature Operation, and Recent Tank Analyses," WSRC-TR2002-00150, Rev. 0 (April, 2002). 
WSRC-TR-2000-00293, Rev. 1

75 D.E. White, W.W. Brannock, and K.J. Murata, "Silica in Hot-Spring Waters," Geochim. Cosmochim. Acta, 10, 27-59 (1956). 


\section{Appendix A}

\section{Estimation of Activity Coefficients}

The abcissa and the ordinate of the activity diagrams used to model the SRS Evaporators are expressed in terms of the activities of the dissolved species $\left(\mathrm{a}_{\mathrm{i}}\right)$ and not the molar concentrations $\left(\mathrm{m}_{\mathrm{i}}\right)$. In order to relate the activities $\left(\mathrm{a}_{\mathrm{i}}\right)$ to the concentrations $\left(\mathrm{m}_{\mathrm{i}}\right)$ of one must be able to calculate the activity coefficient $\left(\gamma_{i}\right)$ through the relationship shown in Equation A-1.

$$
\mathrm{a}_{\mathrm{i}}=\gamma_{\mathrm{i}} \mathrm{m}_{\mathrm{i}}
$$

The activity coefficients are a strong function of the ionic strength (I) of a solution: the activity coefficients are known to increase with increasing ionic strength and there are various methods described in the literature to estimate this effect. All of the methodologies relate the logarithm of $\gamma_{i}$ to a function of $I^{1 / 2}$ with or without additional terms. The activity coefficient estimation used in GWB for extrapolation to high ionic strength is known as the B• (B-dot) method of Helgeson. ${ }^{1}$ Various known approaches, all aimed at modeling the increase of activity coefficients at high ionic strength, were examined (Table A.1).

Table A.1. Effects Modeled in the Various Approaches to Activity Coefficient Estimation in High Ionic Strength Solutions

\begin{tabular}{|l|l|}
\hline Estimation Method for $\gamma_{i}$ & Effects Modeled \\
\hline Debye Huckel & Ion charge and size \\
\hline Davies & $\begin{array}{l}\text { Ion charge and average size, constant } \\
\text { binary interaction term }\end{array}$ \\
\hline Mean Salt & $\begin{array}{l}\text { Ion charge and size, ion specific binary } \\
\text { interactions, ions of opposite sign }\end{array}$ \\
\hline Truesdell-Jones (TJ) & $\begin{array}{l}\text { Ion charge and size, ion specific binary } \\
\text { interactions, ions of opposite sign }\end{array}$ \\
\hline $\begin{array}{l}\text { Specific Ion Interaction } \\
\text { Theory (SIT) }\end{array}$ & $\begin{array}{l}\text { Ion charge and average size, ion specific } \\
\text { binary interactions, ions of opposite sign }\end{array}$ \\
\hline Bromley & $\begin{array}{l}\text { Ion charge, average size, binary and ternary } \\
\text { interactions, ions of opposite sign }\end{array}$ \\
\hline Pitzer & $\begin{array}{l}\text { Ion charge, average size, binary and ternary } \\
\text { interactions, ions of opposite and the same } \\
\text { sign }\end{array}$ \\
\hline Helgeson,s B• (B-dot) & $\begin{array}{l}\text { Ion charge, average size, ion specific } \\
\text { binary interactions, ions of opposite and the } \\
\text { same sign, temperature primarily for brines }\end{array}$ \\
\hline
\end{tabular}




\section{WSRC-TR-2000-00293, Rev. 1}

In order to minimize the dependence of the modeling on the activity coefficient estimation used in GWB, the solubility and/or extrapolated solubility of the NAS $\mathrm{Nel}_{\text {gel }}$, the mixed zeolite, Zeolite-A, hydroxysodalite, gibbsite, diaspore, and $\mathrm{NaAlO}_{2}$ at 8.5 molal $\mathrm{Na}$ were used as input. The nature of the extrapolation from lower Na molality to 8.5 molality is discussed in Appendix B and the effect of using the solubility in GWB for diaspore in dilute solutions vs. using the solubility at 8.5 molal is shown in Figure 10 of the text. While the effect for diaspore is large, the effect for gibbsite (see Figure 10) is relatively small. Once the solubility at 8.5 molal was used in the activity diagrams calculated in this study, specifying a molality of $\mathrm{I}=1$ or $\mathrm{I}=3$ (the default value in the Helgeson approximation in GWB) made little difference. However, the default value of $\mathrm{I}=3$ was used and the basis for that estimation is discussed below.

All estimations of the ionic strength effects on the activity coefficients are basically improvements to the Debye-Huckel equation which is used to estimate activity coefficients $\left(\gamma_{i}\right)$ in dilute solutions., 3 The Debye-Huckel equation assumes that ion interactions are purely Coulombic, ion size does not vary with ionic strength, and ions of the same sign do not interact. ${ }^{3}$ The Debye-Huckel equation has been found to give reasonable activity coefficients for monovalent ions up to an ionic strength (I) of $\sim 0.1$ $\mathrm{mol} / \mathrm{kg}$, for divalent ions to $\sim 0.01 \mathrm{~mol} / \mathrm{kg}$, and for trivalent ions up to $\sim 0.001 \mathrm{~mol} / \mathrm{kg}^{3}$ The Debye-Huckel equation takes on the form

$$
\log \gamma=\frac{-\mathrm{Az}_{\mathrm{i}}^{2} \sqrt{\mathrm{I}}}{1+\mathrm{Ba}_{\mathrm{i}} \sqrt{\mathrm{I}}}
$$

where $A=1.824928 \times 10^{6} \rho_{0}^{1 / 2}(\varepsilon T)^{-3 / 2}, B=50.3 \varepsilon T^{1 / 2}$, with $\rho_{0}$ being the density of water, $\varepsilon$ the dielectric constant of water, and $\mathrm{T}$ the temperture in kelvin. The dielectric constant of water can be obtained from the equation $\varepsilon=2727.586+0.6224107 \mathrm{~T}-466 / 9151 \ln \mathrm{T}$ $52000.87 / \mathrm{T}$.

The Debye-Huckel equation predicts activity coefficients which decline continuously with ionic strength while ion activity coefficients are known to increase at high ionic strengths. Because of this the Debye-Huckel equation underestimates the activity coefficients (Figure A1).

For intermediate ionic strengths between $0.1 \mathrm{~mol} / \mathrm{kg}$ and $3.5 \mathrm{~mol} / \mathrm{kg}$, the Davies method, the mean salt method, the TJ method, and the SIT methods are often employed to add positive terms to extend the Debye-Huckel expression for $\log \gamma .^{3}$ The Davies method adds an empirically determined constant to the Debye-Huckel equation (see Equation A3 ) which accounts for lowering of the dielectric constant of water and increased ion pairing in high ionic strength solutions.

$$
\log \gamma=-\mathrm{Az}^{2}\left(\frac{\sqrt{\mathrm{I}}}{1+\sqrt{\mathrm{I}}}-0.3 \mathrm{I}\right)
$$




\section{WSRC-TR-2000-00293, Rev. 1}

The Davies equation has been found to be accurate for monovalent salts up to ionic strengths of $0.1-0.7 \mathrm{~mol} / \mathrm{kg}$ and inaccurate at low ionic strengths (see Figure A1). ${ }^{3}$

The mean salt method is based on measured activity coefficients of electrolyte salts such as $\mathrm{KCl}, \mathrm{Na}_{2} \mathrm{SO}_{4}, \mathrm{~K}_{2} \mathrm{SO}_{4}$, etc. For $\mathrm{KCl}$ the activity coefficient of $\mathrm{K}^{+}$equals that of $\mathrm{Cl}^{-}$. If the mean activity coefficient of another pair of ions, e.g., $\mathrm{K}^{+}$and $\mathrm{SO}_{4}{ }^{2-}$, has been measured, then the activity coefficient of $\mathrm{SO}_{4}{ }^{2-}$ can be calculated by difference. ${ }^{2}$ Thus, a table of values for other ions can be built up from the appropriate mean ion activity coefficients. The errors involved become greater as the linkage of one mean activity pair to another cation or anion becomes mathematically more distant. For the example given in Figure A1 the mean salt method is considered accurate and shows how the other activity coefficient models either overestimate or underestimate the activity coefficients as a function of ionic strength. Measured mean activity coefficients for uranium and silicate salts needed to apply this method to evaporator solutions do not exist.

The TJ equation and the mean salt method give approximately the same activity coefficients (Figure A1). In the TJ method an add-on term to the Debye-Huckel equation, $b \bullet I$, is employed. ${ }^{3}$ Each $b \bullet I$ term is ion-specific, and the $b$ term is determined empirically by fitting the TJ equation to individual ion activity coefficients obtained from the mean salt method. The ion size and $b$ values for $\mathrm{U}^{6+}$ and $\mathrm{Si}^{4+}$ needed for the current study are not known. ${ }^{3}$ The TJ equation is given as:

$$
\log \gamma=\frac{-\mathrm{Az}_{\mathrm{i}}^{2} \sqrt{\mathrm{I}}}{1+\mathrm{Ba}_{\mathrm{i}} \sqrt{\mathrm{I}}}+\mathrm{bI}
$$

Which is the same as the Debye-Huckel equation given in Equation A-2 with an additional bI term added.

The specific ion interaction theory (SIT) calculates an add-on term to the Debye-Huckel equation based on ion- and electrolyte-specific approach. ${ }^{3}$ The SIT methodology is considered more accurate than the Davies equation. The generalized SIT equation for a single ion, $\mathrm{i}$, is given as

$$
\log \gamma_{i}=-z^{2} D+\sum_{k} \varepsilon(i, j, I) m(j)
$$

where $\mathrm{D}$ is the Debye Huckel term, $\mathrm{D}=\left(\frac{0.5901 \sqrt{\mathrm{I}}}{1+1.5 \sqrt{\mathrm{I}}}\right)$ at room temperature, $\mathrm{z}$ is the charge of the ion $\mathrm{i}, \mathrm{m}(\mathrm{j})$ is the molality of the major electrolyte ion $\mathrm{j}$ which is of opposte charge to the ion $\mathrm{i}$, and $\varepsilon(\mathrm{I}, \mathrm{j}, \mathrm{I})$ is the interaction parameter between ion $\mathrm{i}$ and major electrolyte ion $\mathrm{j}$. The SIT estimations are accurate in $\sim 3.5$ molal solutions. ${ }^{3}$ An interaction term exists for aqueous $\mathrm{UO}_{2}^{2+}$ but not for any silicate species. 


\section{WSRC-TR-2000-00293, Rev. 1}

For high ionic strength solutions ( $\mathrm{I}=2$ to $6 \mathrm{~mol} / \mathrm{kg}$ ) the high density of ions in solution can lead to binary interactions between species of like charge and ternary interactions between three or more ions, some of which will be of like sign. In such systems some ions must be touching, and dilute solution concepts do not apply. The most accurate model for high ionic strength solutions up to 6 molal solutions is the Pitzer model. The Pitzer model takes into account the short-range electrostatic interactions in concentrated solutions $^{3}$ and a term for triple ion interactions (virial coefficients). The generalized equation for the Pitzer model approach for an individual ion is

$$
\log \gamma_{i}=z^{2} f^{y}+\sum_{i} D_{i j}(I) m(j)+\sum_{i j k} E_{i j k} m_{j} m_{k}+\ldots
$$

where the first term on the right is a modified Debye Huckel and $\mathrm{f}^{\mathrm{y}}$ is dependent on the ionic strength, the second term on the right is the sum of interactions that involve two solution species of opposite or the same sign. Those describing the interaction of species of opposite sign (B terms) are functions of ionic strength while the interaction of like sign species ( $\theta$ terms are assumed independent of ionic strength. The Pitzer model equations are linear algebraic functions of $\ln \gamma_{i}$ while are often extremely long and involve numerous individual parameters and substitutions. Currently the necessary U and Si terms necessary for modeling evaporator solutions have not been calculated.

The Bromley model, ${ }^{4}$ a simplification of the Pitzer model, can also be used up to ionic strengths of $6 \mathrm{~mol} / \mathrm{kg}$. The interactions among ions of the same sign are neglected, so the uncertainty increases at high ionic strength. ${ }^{5}$ For both of these models, the necessary $\mathrm{U}$ and Si terms necessary for modeling evaporator solutions have not been calculated..

The B-dot (B॰) method of Helgeson, ${ }^{6}$ embedded in The Geochemist's Workbench (GWB) software, was able to calculate activity coefficients and activities in a consistent manner for all species including $\mathrm{U}^{6+}$ and $\mathrm{Si}^{4+}$. The symbol $\mathrm{B}^{\bullet}$ is a deviation function used to describe the departure of the log of the mean ionic activity coefficient from that predicted by the Debye-Huckel expression. Pitzer and Brewer ${ }^{7}$ designated this deviation function as $\mathrm{B}^{\circ}$. The function, as modified by Helgeson, ${ }^{6}$ includes a parameter for the distance of closest approach of the ions in solution as defined by Pitzer and Brewer. ${ }^{7}$ In this method the activity coefficients are calculated by using the solution's ionic strength, and the water activity is calculated from the stoichiometric ionic strength. It is a modified form of Equation A-3 and expresses the activity coefficient of the $i^{\text {th }}$ ion as a function of ionic strength and temperature as

$$
\log \gamma_{i}^{*}(T, \bar{I})=\frac{-A(T) z_{i}^{2} \sqrt{\bar{I}}}{1+B(T) a_{i}(T) \sqrt{\bar{I}}}+B^{\bullet}(T) \bar{I}
$$

where $\overline{\mathrm{I}}$ is the ionic strength, and the ionic sizes and constants are all functions of temperature. The $\mathrm{B}^{\bullet}$ term is the deviation function equal to 


$$
-\frac{h(T)}{v}-\log a_{w}(T \bar{I})-\log [1-0.018 m(v-h(t))]
$$

where $\mathrm{a}_{\mathrm{w}}$ is the activity of water, $\mathrm{m}$ is the molality of the completely dissociated solute, $\mathrm{v}$ is the number of ions per mole of solute, and $\mathrm{h}$ is the average number of water molecules coordinated to $\mathrm{v}$ ions in solution. This is based on the Stokes-Robinson equation which describes the concentration dependence of the mean ionic activity coefficient of a large number of strong electrolytes to high concentrations at $25^{\circ} \mathrm{C}$. As applied in $\mathrm{GWB}$, the $\mathrm{B}^{\circ}$ coefficients have been correlated to ionic strengths of 3 molal and temperatures of $\sim 300^{\circ}$ assuming $\mathrm{NaCl}$ as the major electrolyte in geochemical brines.

Since evaporator solutions are not primarily $\mathrm{NaCl}$ brines, the solubility and/or extrapolated solubility of silicate and aluminate phases at 8.5 molal $\mathrm{Na}$ were used rather than relying on activity coefficient extrapolations. The nature of the extrapolation from lower Na molality to 8.5 molality is discussed in Appendix B and the effect of using the solubility in GWB for diaspore in dilute solutions vs. using the solubility at 8.5 molal is shown in Figure 10 of the text and discussed in Appendix B.

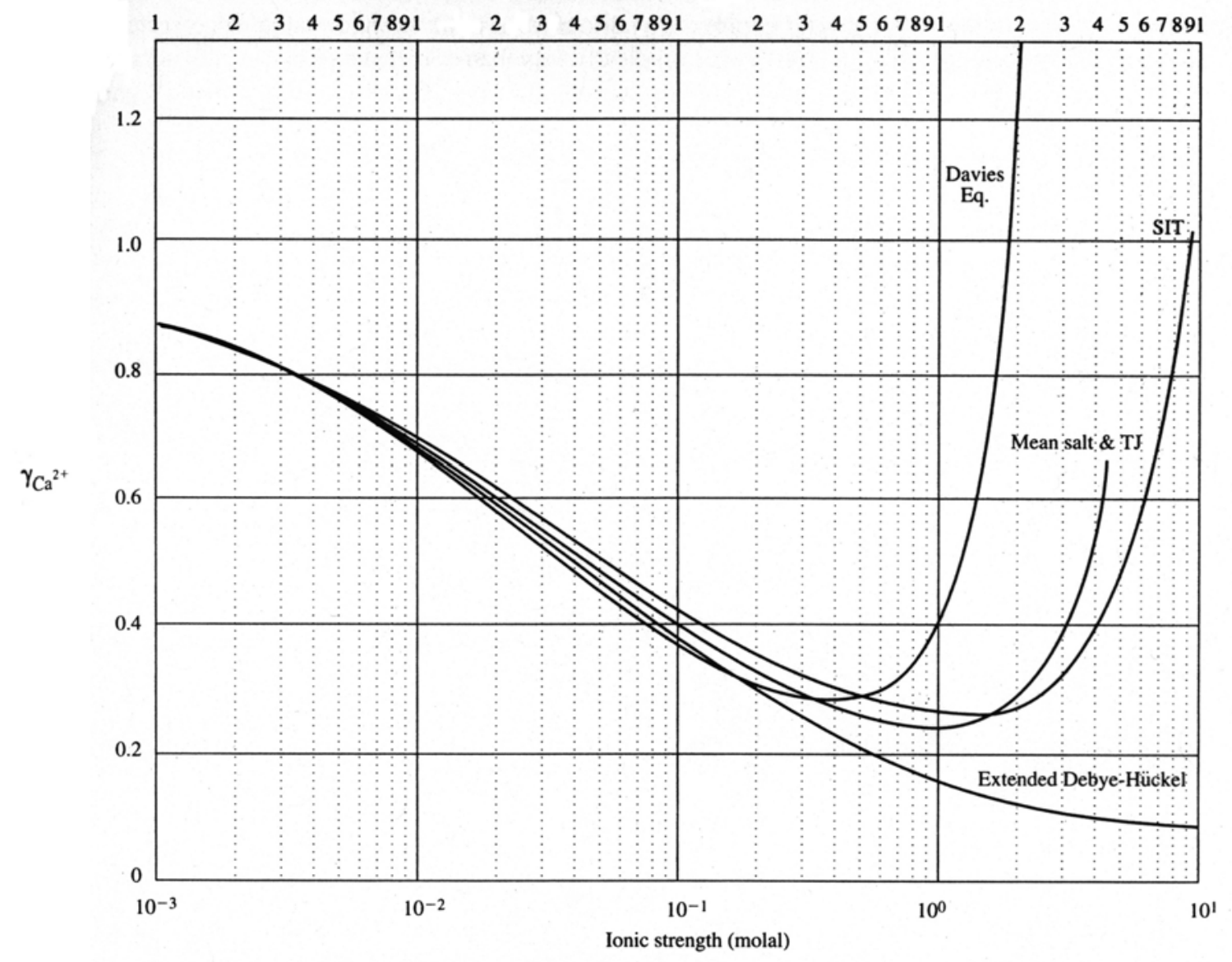

Figure A1. Comparison of the ion activity coefficient of $\mathrm{Ca}^{2+}$ as computed using different methods as discussed in the text (from Langmuir ${ }^{3}$ ) 


\section{APPENDIX A REFERENCES}

H. C. Helgeson, "Thermodynamics of Hydrothermal Systems at Elevated Temperatures and Pressures," Am. J. Sci., 267, 729-804 (1969).

$2 \quad$ R. M. Garrels and C. L. Christ, "Solutions, Minerals, and Equilibria," Harper \& Row, New York, 450pp. (1965).

3 D. Langmuir, “Aqueous Environmental Geochemistry,” Prentice Hall, Upper Saddle River, New Jersey, 600pp. (1997)

4 L. A. Bromley, "Thermodynamic Properties of Strong Electrolytes in Aqueous Solutions," Am. Inst. Chem. Eng. Journal, 19 [2], 313-320 (1973).

5 A. L. Horvath, "Handbook of Aqueous Electrolyte Solutions," John Wiley \& Sons, New York, 631pp. (1985).

6 H. C. Helgeson, "Thermodynamics of Hydrothermal Systems at Elevated Temperatures and Pressures," Am. J. Sci., 267, 729-804 (1969).

7 K. S. Pitzer and L. Brewer, "Thermodynamics, $2^{\text {nd }}$ Edition of Revision of Thermodynamics" in G. N. Lewis and M. Randall, McGraw-Hill, New York, 723pp. (1961). 
WSRC-TR-2000-00293, Rev. 1

\section{Appendix B \\ Augmentation and Validation of Solubility Data in Geochemist's Workbench}

This appendix describes the addition to or modification of formation constants in Geochemist's Workbench (GWB) to enable this software to model aluminosilicate solubilities. The calculations in this study use the THERMO database, which contains the greatest number of species of any of the GWB databases. THERMO lacks several species needed to model aluminosilicate solubilities, however. These species include undissociated $\mathrm{NaNO}_{3}(\mathrm{aq})$, sodium aluminate $\left(\mathrm{NaAlO}_{2}\right)$, amorphous sodium aluminosilicate (NAS) $\left(\mathrm{Na}_{12} \mathrm{Al}_{12} \mathrm{Si}_{14} \mathrm{O}_{52} \bullet 31 \mathrm{H}_{2} \mathrm{O}\right)$, Zeolite-A $\left(\mathrm{Na}_{12} \mathrm{Al}_{12} \mathrm{Si}_{12} \mathrm{O}_{48} \bullet 27 \mathrm{H}_{2} \mathrm{O}\right)$, a so-called mixed zeolite with the same formula as Zeolite-A, and hydroxysodalite $\left(\mathrm{Na}_{8} \mathrm{Al}_{6} \mathrm{Si}_{6} \mathrm{O}_{24} \bullet 2 \mathrm{H}_{2} \mathrm{O}\right)$. This appendix details the calculation of formation constants for each of these species. In addition, this appendix benchmarks the formation constants for silicate and aluminate minerals in THERMO with measured solubilities. The comparisons for aluminates showed the need for modified formation constants for gibbsite and diaspore.

\section{Modeling of Aqueous Species}

The first step in developing a thermodynamic equilibrium model such as that used by GWB is to ensure that the model includes all applicable aqueous species. To model aluminosilicate solubilities, the list of applicable species must include, at a minimum, all species that participate in the precipitation reactions plus major solution constituents. For the evaporator solutions, the applicable species are the silicate and aluminate ions that are prevalent in basic solution, $\mathrm{Na}^{+}, \mathrm{NO}_{3}{ }^{-}, \mathrm{NO}_{2}{ }^{-}, \mathrm{OH}^{-}, \mathrm{NaNO}_{3}(\mathrm{aq}), \mathrm{NaNO}_{2}(\mathrm{aq})$, and $\mathrm{NaOH}(\mathrm{aq})$.

As explained in Section 5.0, the default GWB database models the silicate species $\mathrm{SiO}_{2}$ (aq), $\mathrm{H}_{3} \mathrm{SiO}_{4}{ }^{-}$, and $\mathrm{H}_{2} \mathrm{SiO}_{4}{ }^{2-}$, as well as some polyatomic ions. Babushkin ${ }^{1}$ also reports equilibrium activities for trivalent and quatravalent silicate species in very basic solutions. The existence of these species has not been confirmed elsewhere, ${ }_{-2}{ }^{3}$ so these species are not modeled. The only aluminate species that is present at a significant concentration in basic solutions is $\mathrm{Al}(\mathrm{OH})_{4}{ }^{-}$, which also is in the default $\mathrm{GWB}$ database.

To simplify the modeling of the evaporator solutions, this study combines measured nitrite and nitrate concentrations and treats solutions as if they are comprised entirely of nitrates. This simplification presumes that nitrates and nitrites behave similarly in basic solutions and that nitrated and nitrited aluminosilicates have equivalent solubilities. It avoids the need to develop separate equilibrium models for nitrated and nitrited sodalites and cancrinites and separate activity relationships for nitrates and nitrites. The GWB database has activity models for $\mathrm{Na}^{+}, \mathrm{NO}_{3}{ }^{-}, \mathrm{OH}^{-}$, and $\mathrm{NaOH}(\mathrm{aq})$. The only major constituent species that is missing is undissociated sodium nitrate. 


\section{WSRC-TR-2000-00293, Rev. 1}

The estimation of the formation constant for undissociated sodium nitrate is based on an analogy with sodium chloride. The convention in GWB is to make the formation constants proportional to the tendency to dissolve or dissociate, so that higher formation constants give greater fractional dissociations. Following this convention in terms of logarithms, the analogy takes the form

$$
\log \left(\mathrm{K}_{\mathrm{f}, \mathrm{NaNO}_{3}}\right)=\log \left(\mathrm{K}_{\mathrm{f}, \mathrm{NaCl}}\right)+\log \left(\frac{\mathrm{K}_{\mathrm{d}, \mathrm{NaCl}}}{\mathrm{K}_{\mathrm{d}, \mathrm{NaNO}_{3}}}\right)
$$

where the dissociation constants are evaluated at single temperatures ${ }^{4}$

$$
\mathrm{K}_{\mathrm{d}, \mathrm{NaCl}}=10^{-0.78} \frac{\mathrm{mol}}{\mathrm{L}} \text { at } 25^{\circ} \mathrm{C}
$$

and

$$
\mathrm{K}_{\mathrm{d}, \mathrm{NaNO}_{3}}=10^{-0.59} \frac{\mathrm{mol}}{\mathrm{L}} \text { at } 18^{\circ} \mathrm{C}
$$

\section{Modeling of Mineral Species}

Most of the changes to the THERMO database consist of modifications and additions of solubilities for aluminum and aluminosilicate minerals. The general approach used to model these solubilities treats the activity coefficient models within THERMO as a "black box". In this approach, the logs of the minerals' formation constants are set to match the calculated solubilities to average measured solubilities. To compute the desired log formation constant, this constant is arbitrarily set to zero, and the REACT program is run with the measured solution composition. The computed value for supersaturation (" $\mathrm{Q} / \mathrm{K}$ ") equals the $\log$ of the formation constant for the mineral solubility.

Because the B-dot activity coefficient model used in THERMO is not accurate beyond GWB's default ionic strength of 3 molal, accurate solubility calculations require an adjustment for more concentrated solutions. Accordingly, all solubility calculations use the average ionic strength for the evaporator solutions, which is approximated by setting the soluble sodium concentration equal to 8.5 molal. The following sections describe adjustments to measured solubilities for individual minerals.

\section{Benchmarking of Silicate Solubilities}

The benchmark calculations for silicates compare THERMO model solubilities with measured solubilities for amorphous silica. Alexander, Heston, and Iler ${ }^{5,6}$ measured 


\section{WSRC-TR-2000-00293, Rev. 1}

solubilities for pure amorphous silica in aqueous $\mathrm{HCl}$ and $\mathrm{NaOH}$ solutions. The benchmarking of these measurements consists of an activity diagram, generated by the ACT2 program, that compares measured and calculated silicate solubilities as a function of silicate activity versus $\mathrm{pH}$. The first step in the benchmarking is to calculate a silicate activity from measured solution compositions, using the REACT program. The activity in ACT2 solubility diagrams incorporates all ionic species of a given mineral. For instance, for amorphous silicate, the activity is defined in terms of $\mathrm{SiO}_{2}(\mathrm{aq})$ but includes the monovalent and divalent species, $\mathrm{H}_{3} \mathrm{SiO}_{4}{ }^{-}$and $\mathrm{H}_{2} \mathrm{SiO}_{4}{ }^{2-}$, as well as the polyatomic species $\mathrm{H}_{4}\left(\mathrm{SiO}_{4}\right)_{4}{ }^{4-}$ and $\mathrm{H}_{6}\left(\mathrm{SiO}_{4}\right)_{4}{ }^{2-}$. Consequently, the desired activity is the total solubility for all silicate species, multiplied by the activity coefficient for $\mathrm{SiO}_{2}(\mathrm{aq})$. Table B-1 summarizes the results of the REACT activity calculations. As this table indicates, the activities for acid solutions involved a charge balance with $\mathrm{Cl}^{-}$, which REACT performs automatically. The automatic charge balance does not work for $\mathrm{Na}^{+}$, so the activity calculations for basic solutions required a trial and error solution using a specified $\left[\mathrm{Na}^{+}\right]$. The log activity listed in the table is the total for all ionic species.

Table B-1. Measured Silicon Solubilities and Calculated Silicon Activities at $25^{\circ} \mathrm{C}$.

\begin{tabular}{|c|c|c|c|}
\hline pH & {$[\mathrm{Si}]\left(\mathrm{mg} / \mathrm{kg} \mathrm{H} \mathrm{H}_{2} \mathrm{O}\right)$} & {$\left[\mathrm{Na}^{+}\right]\left(\mathrm{mg} / \mathrm{kg} \mathrm{H} \mathrm{H}_{2} \mathrm{O}\right)$} & $\log \operatorname{activity}(\mathbf{S i})$ \\
\hline 1 & 140 & * & -2.6192 \\
\hline 2 & 150 & $*$ & -2.6014 \\
\hline 3 & 150 & $*$ & -2.6026 \\
\hline 4.2 & 130 & $*$ & -2.6648 \\
\hline 5.7 & 110 & $*$ & -2.7374 \\
\hline 7.7 & 100 & 0.308 & -2.7787 \\
\hline 10.26 & 490 & 145.1 & -2.1238 \\
\hline 10.60 & 1120 & 372.0 & -1.7833 \\
\hline 10.85 & 2100 & 758.2 & -1.5326 \\
\hline 11.04 & 3600 & 1376.0 & -1.3206 \\
\hline
\end{tabular}

* The REACT input specifies the $\mathrm{pH}$ and balances the charge with $\mathrm{Cl}^{-}$.

Figure B-1 compares measured and predicted silicate activities. As this figure shows, the silicate solubility is nearly constant for acid and neutral solutions, but rises sharply above a $\mathrm{pH}$ of about 9.8. When the $\mathrm{pH}$ is between 9.8 and 11, the dominant ionic species is $\mathrm{H}_{3} \mathrm{SiO}_{4}{ }^{-}$, and the $\mathrm{pH}$ rises sharply. The default THERMO model accurately predicts solubilities in both of these $\mathrm{pH}$ ranges. Above a $\mathrm{pH}$ of 11, polyatomic species prevail, and the solubility increases even faster with increasing $\mathrm{pH}$. The fact that the solubility measurements stopped at $\mathrm{pH} 11$ suggests that solubility measurements are difficult in basic solutions - the reason may be that amorphous silica and polyatomic silicate ions don't form distinct phases. Despite the lack of silica solubility data at high $\mathrm{pH}$, the THERMO model predicts measured solubilities in acid, neutral, and moderately basic solutions sufficiently well to demonstrate its validity. Therefore, this study uses the default silicate formation constants in the THERMO database. 
WSRC-TR-2000-00293, Rev. 1

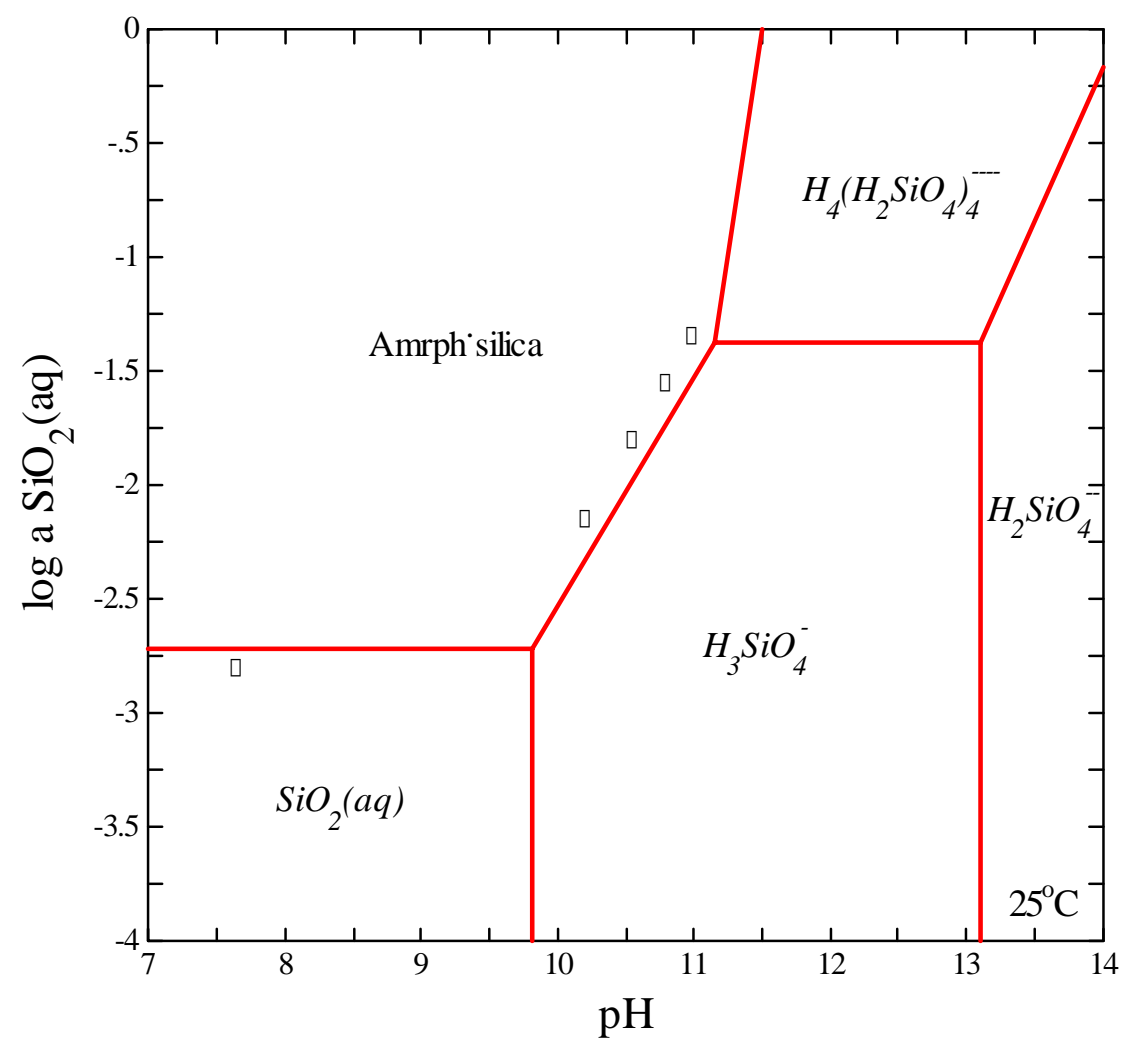

Figure B-1. Comparison of Iler et al. Silica Solubilities with THERMO Predictions

\section{Modeling of Sodium Aluminate Solubilities}

Sodium aluminate can precipitate from basic solutions that contain sodium and high concentrations of aluminum, so an analysis of aluminosilicate solubilities should incorporate a model of sodium aluminate solubility. Reynolds and Herting ${ }^{7}$ provide a statistically derived correlation for sodium aluminate solubilities. Their correlation represents a best fit to measured solubilities in simulated Hanford waste tank solutions containing $\mathrm{NaOH}, \mathrm{NaNO}_{3}, \mathrm{NaNO}_{2}$, and $\mathrm{NaAlO}_{2}$. They conducted tests in which these salts precipitated from supersaturated solutions over a four-week period.

With the nitrate and nitrite terms dropped, the Reynolds and Herting correlation takes the form

$$
\left[\mathrm{NaAlO}_{2}\right]=9.359-0.0899 \mathrm{~T}-0.567\left[\mathrm{OH}^{-}\right]+0.000629 \mathrm{~T}^{2}+0.00304 \mathrm{~T}\left[\mathrm{OH}^{-}\right]
$$

where the temperature is in ${ }^{\circ} \mathrm{C}$ and the concentrations are in molal units. This correlation covers the ranges $5.0 \leq\left[\mathrm{OH}^{-}\right] \leq 11.5$ and $60 \leq \mathrm{T} \leq 100$. The concentration range is equivalent to that of the SRS evaporator tank solutions. SRS Evaporator, feed tank, and drop tank can be either higher or lower than the specified temperature range, so modeling of the SRS evaporator solutions requires a temperature extrapolation. Figure B-2, copied from Reynolds and Herting, illustrates the variation of sodium aluminate solubilities over 
the specified concentration and temperature ranges. Note that for $[\mathrm{NaOH}] \geq 8$ the solubility increases at an apparent exponential rate with temperature. This suggests that solubilities can be extrapolated to higher and lower temperatures using a linear function of the log of the solubility product.

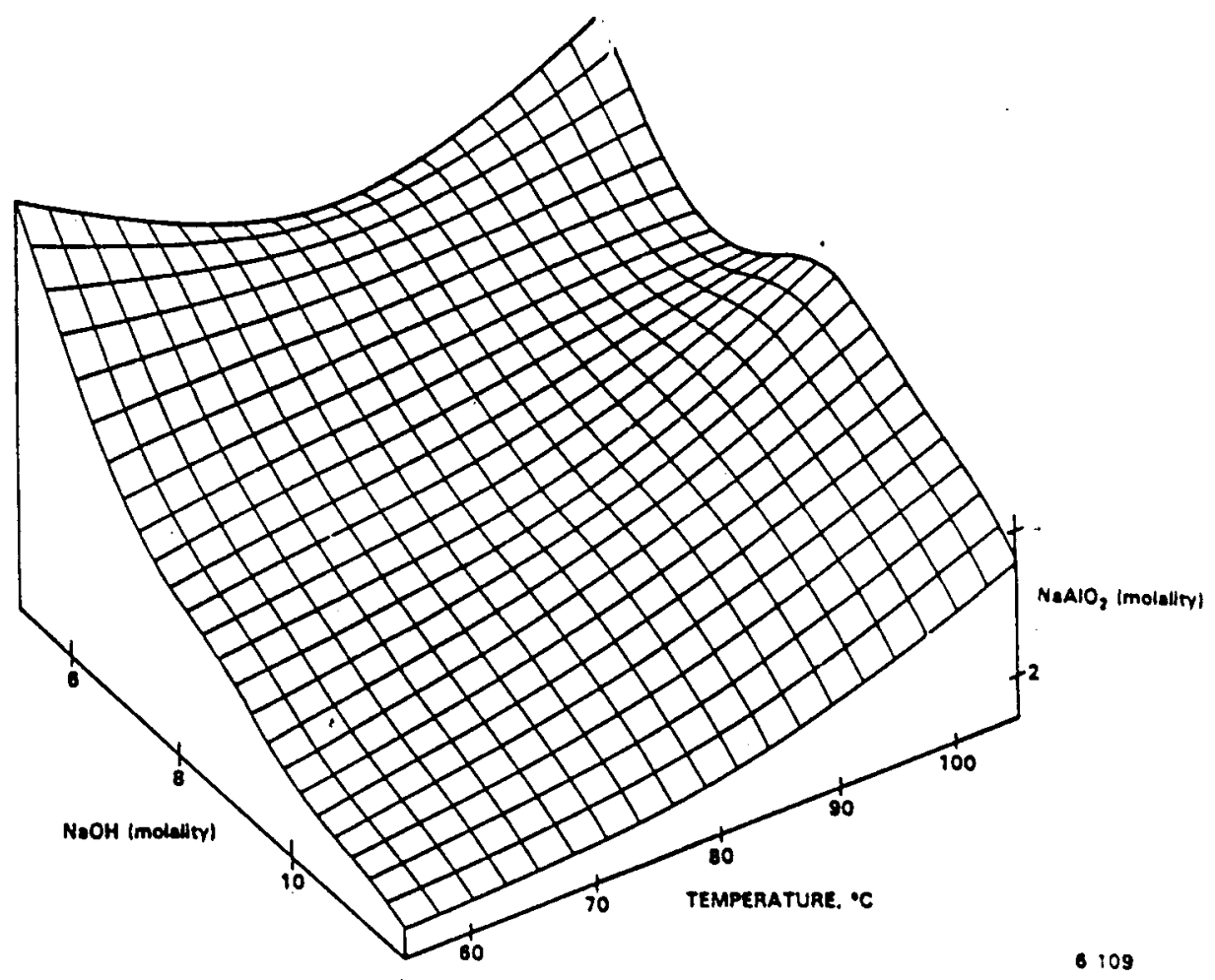

Figure B-2. Reynolds and Herting ${ }^{7}$ Sodium Aluminate Solubilities as a Function of Temperature and [NaOH].

The calculation procedure for extrapolating the solubility product outside the temperature range for the Reynolds and Herting correlation assumes that the only ionic species in solution are $\mathrm{Na}^{+}, \mathrm{OH}^{-}$, and $\mathrm{AlO}_{2}^{-}$. The procedure begins with the calculation of $\left[\mathrm{OH}^{-}\right]$ and $\left[\mathrm{AlO}_{2}^{-}\right]$given $\left[\mathrm{Na}^{+}\right]=8.5$. Application of a charge balance and a rearrangement of Equation B-4 give $\left[\mathrm{OH}^{-}\right]$.

$$
\left[\mathrm{OH}^{-}\right]=\frac{\left[\mathrm{Na}^{+}\right]-9.359+0.0899 \mathrm{~T}-0.000629 \mathrm{~T}^{2}}{1-0.567+0.00304 \mathrm{~T}}
$$

A repeated application of the charge balance gives $\left[\mathrm{AlO}_{2}^{-}\right]$as the difference between $\left[\mathrm{Na}^{+}\right]$and $\left[\mathrm{OH}^{-}\right]$.

$$
\left[\mathrm{AlO}_{2}^{-}\right]=\left[\mathrm{Na}^{+}\right]-\left[\mathrm{OH}^{-}\right]
$$




\section{WSRC-TR-2000-00293, Rev. 1}

Next, multiplication of $\left[\mathrm{Na}^{+}\right]$by $\left[\mathrm{AlO}_{2}^{-}\right]$yields the solubility product, $\mathrm{K}_{\mathrm{sp}}$.

$$
\mathrm{K}_{\mathrm{sp}}=\left[\mathrm{Na}^{+}\right]\left[\mathrm{AlO}_{2}^{-}\right]
$$

In the remaining steps, a linear extrapolation of $\log \left(\mathrm{K}_{\mathrm{sp}}\right)$, calculated at $60^{\circ} \mathrm{C}$ and $100^{\circ} \mathrm{C}$, gives $\log \left(\mathrm{K}_{\mathrm{sp}}\right)$ for the temperatures used by the THERMO database. Exponentiation of the logarithms and division by $\left[\mathrm{Na}^{+}\right]$yield $\left[\mathrm{AlO}_{2}{ }^{-}\right]$, which is equivalent to $\left[\mathrm{Al}(\mathrm{OH})_{4}{ }^{-}\right]$in the THERMO database. The last step entails the calculation of the log of the formation constant for sodium aluminate, using the REACT program. Input items for this calculation are the temperature, $\left[\mathrm{Na}^{+}\right]$, and $\left[\mathrm{Al}(\mathrm{OH})_{4}{ }^{-}\right]$. Table B-2 summarizes the results of these calculations.

Table B-2. Summary of Formation Constant Calculations for the Solubility of Sodium Aluminate.

\begin{tabular}{|c|c|c|c|c|c|c|c|c|}
\hline $\begin{array}{l}\mathbf{T} \\
\left({ }^{\circ} \mathbf{C}\right)\end{array}$ & $\begin{array}{l}{\left[\mathrm{Na}^{+}\right]} \\
(\text {molal })\end{array}$ & $\begin{array}{l}{\left[\mathrm{OH}^{-}\right]} \\
\text {(molal) }\end{array}$ & $\begin{array}{l}{\left[\mathrm{NaAlO}_{2}\right]} \\
\text { (molal) }\end{array}$ & $\begin{array}{l}\mathbf{K}_{\mathrm{sp}} \\
\left(\text { molal }^{2}\right)\end{array}$ & $\log \left(K_{\mathrm{sp}}\right)$ & $\begin{array}{l}\mathbf{K}_{\mathrm{sp}} \\
\left(\text { molal }^{2}\right)\end{array}$ & $\begin{array}{l}{\left[\mathrm{Al}(\mathrm{OH})_{4}{ }^{-}\right]} \\
(\text {molal })\end{array}$ & $\log \left(K_{f}\right)$ \\
\hline 0 & 8.5 & & & & 1.3274 & 21.2516 & 2.5002 & 26.1655 \\
\hline 25 & 8.5 & & & & 1.3909 & 24.5983 & 2.8939 & 23.0333 \\
\hline 60 & 8.5 & 4.9486 & 3.5514 & 30.1872 & 1.4798 & 30.1872 & 3.5514 & 20.0355 \\
\hline 100 & 8.5 & 4.0123 & 4.4877 & 38.1455 & 1.5814 & 38.1455 & 4.4877 & 18.3949 \\
\hline 150 & 8.5 & & & & 1.7085 & 51.1057 & 6.0124 & 16.8429 \\
\hline 200 & 8.5 & & & & 1.8355 & 68.4693 & 8.0552 & 15.0884 \\
\hline 250 & 8.5 & & & & 1.9625 & 91.7322 & 10.7920 & 13.1319 \\
\hline 300 & 8.5 & & & & 2.0895 & 122.8990 & 14.4587 & 11.0095 \\
\hline
\end{tabular}

\section{Modeling of Gibbsite and Diaspore Solubilities}

Benchmarking calculations for aluminates compared data from Russell et al. ${ }^{8}$ with the default THERMO database. In a more recent study, Wesolowski ${ }^{9}$ found that the Russell et al. data were consistent with his gibbsite solubility measurements and other gibbsite solubility data. This study uses the Russell et al. data in preference to these other data sets because Russell et al. measured solubilities over a wide range of temperatures and performed separate measurements for the low-temperature gibbsite $\left(\mathrm{Al}(\mathrm{OH})_{3}\right)$ and hightemperature diaspore $(\alpha-\mathrm{AlOOH})$ forms of aluminum hydroxides. Russel et al. Measured the solubilities of these phases in Bayer liquors since these were the phases determined to form in Bayer evaporators. There was no solubility data at 8.5 molal $\mathrm{Na}^{+}$for boehmite $(\delta-\mathrm{AlOOH})$ nor was boehmite a phase found to form in Bayer evaporators. To ensure that they obtained true solubilities for the correct mineral phase, Russell et al. conducted dissolution experiments starting with either pure gibbsite or pure diaspore. This study benchmarks their data for temperatures ranging from $40^{\circ} \mathrm{C}$ to $100^{\circ} \mathrm{C}$ for gibbsite and from $80^{\circ} \mathrm{C}$ to $170^{\circ} \mathrm{C}$ for diaspore. Below $40^{\circ} \mathrm{C}$, dissolutions were too slow to ensure that the test solutions became saturated. The maximum temperature corresponds to the maximum temperature expected for evaporator operation. The relative thermodynamic stabilities of the two mineral phase limit the maximum temperature for gibbsite solubility measurements and the minimum temperature for diaspore solubility measurements. 
The procedure used to benchmark the Russell et al. data involves a separate estimation of the $\log$ of the REACT formation constant for $\left[\mathrm{Na}^{+}\right]=8.5$ molal at each measurement temperature. To begin the process, REACT calculates the log of the formation constant for each measurement using the procedure described previously in this appendix. A linear regresssion of the measurements at each temperature, performed by Microsoft Excel, then gives either an interpolated or extrapolated value for the formation constant at a sodium molality of 8.5. Figures B-3 and B-4 depict typical regressions for gibbsite and diaspore solubilities. The results in these figures show that the log formation constant varies linearly with sodium concentration, justifying the use of linear regressions. Tables B-3 and B-4 list the results of the REACT formation constant calculations and the EXCEL regressions for all gibbsite and diaspore measurements.
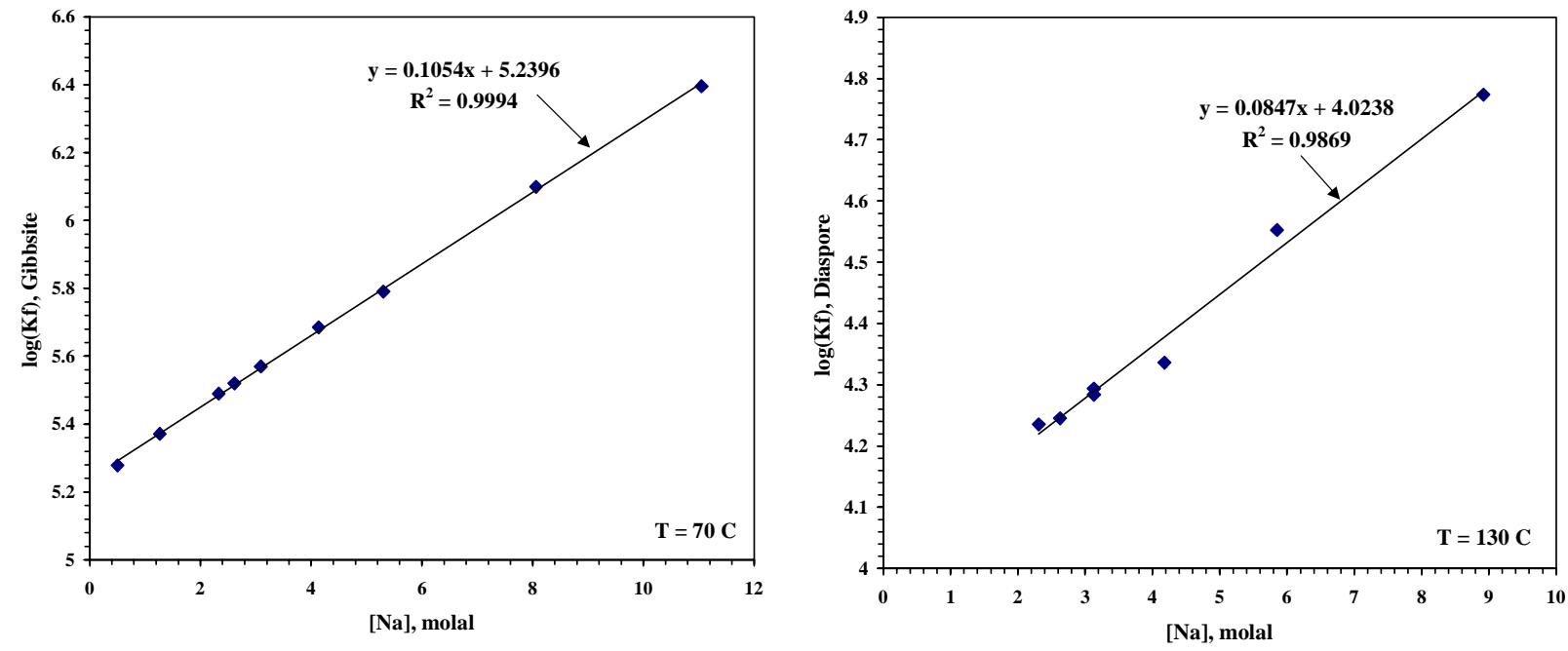

Figure B-3. Variation of the Log Formation Constant Figure B-4. Variation of the Log Formation Constant for Gibbsite with [Na], at $70^{\circ} \mathrm{C}$. for Diaspore with [Na], at $130^{\circ} \mathrm{C}$.

Table B-3. Results of Geochemist's Workbench Calculations of $\mathbf{K}_{\mathbf{f}}$ for Gibbsite

\begin{tabular}{|c|c|c|c|}
\hline $\begin{array}{l}\mathbf{T} \\
\left({ }^{\circ} \mathbf{C}\right)\end{array}$ & $\begin{array}{l}{\left[\mathrm{Na}^{+}\right]} \\
(\text {molal })\end{array}$ & $\begin{array}{l}{\left[\mathrm{Al}(\mathrm{OH})_{4}{ }_{4}\right]} \\
(\text { molal })\end{array}$ & $\log \left(K_{f}\right)$ \\
\hline 40 & 0.4993 & 0.04813 & 6.2084 \\
\hline 40 & 1.245 & 0.1187 & 6.2581 \\
\hline 40 & 2.291 & 0.2794 & 6.4391 \\
\hline 40 & 2.566 & 0.3240 & 6.4707 \\
\hline 40 & 3.061 & 0.3975 & 6.5090 \\
\hline 40 & 4.089 & 0.5767 & 6.5973 \\
\hline 40 & 5.067 & 0.7864 & 6.6869 \\
\hline 40 & 7.883 & 1.791 & 6.9763 \\
\hline 40 & 10.69 & 3.454 & 7.2690 \\
\hline \multicolumn{3}{|c|}{ interpolated at 8.5 molal $\left[\mathrm{Na}^{+}\right]$} & 7.0485 \\
\hline 50 & 0.498 & 0.0663 & 5.8314 \\
\hline 50 & 1.2619 & 0.1624 & 5.8708 \\
\hline
\end{tabular}


WSRC-TR-2000-00293, Rev. 1

Table B-3. Results of Geochemist's Workbench Calculations of $\mathbf{K}_{\mathbf{f}}$ for Gibbsite (continued)

\begin{tabular}{|c|c|c|c|}
\hline $\begin{array}{l}\mathbf{T} \\
\left({ }^{\circ} \mathbf{C}\right)\end{array}$ & $\begin{array}{l}{\left[\mathrm{Na}^{+}\right]} \\
\text {(molal) }\end{array}$ & $\begin{array}{l}{\left[\mathrm{Al}(\mathrm{OH})_{4}{ }^{-}\right]} \\
(\mathrm{molal})\end{array}$ & $\log \left(K_{f}\right)$ \\
\hline 60 & 0.5085 & 0.08558 & 5.3983 \\
\hline 60 & 1.244 & 0.2133 & 5.4612 \\
\hline 60 & 2.313 & 0.4761 & 5.6223 \\
\hline 60 & 2.577 & 0.5487 & 5.6553 \\
\hline 60 & 3.083 & 0.6731 & 5.6953 \\
\hline 60 & 4.083 & 0.9739 & 5.7948 \\
\hline \multicolumn{3}{|c|}{ extrapolated to 8.5 molal $\left[\mathrm{Na}^{+}\right]$} & 6.3199 \\
\hline 70 & 0.5023 & 0.1097 & 5.2788 \\
\hline 70 & 1.267 & 0.2954 & 5.3715 \\
\hline 70 & 2.329 & 0.5961 & 5.4898 \\
\hline 70 & 2.614 & 0.6853 & 5.5200 \\
\hline 70 & 3.092 & 0.8432 & 5.5698 \\
\hline 70 & 4.137 & 1.243 & 5.6851 \\
\hline 70 & 5.305 & 1.746 & 5.7905 \\
\hline 70 & 8.064 & 3.565 & 6.0987 \\
\hline 70 & 11.05 & 6.126 & 6.3955 \\
\hline \multicolumn{3}{|c|}{ interpolated at 8.5 molal $\left[\mathrm{Na}^{+}\right]$} & 6.1355 \\
\hline 80 & 0.5024 & 0.1392 & 5.1073 \\
\hline 80 & 1.268 & 0.3805 & 5.2119 \\
\hline 80 & 2.344 & 0.7648 & 5.3315 \\
\hline 80 & 2.631 & 0.9757 & \\
\hline 80 & 3.143 & 1.090 & 5.4178 \\
\hline 80 & 4.11 & 1.562 & 5.5362 \\
\hline \multicolumn{3}{|c|}{ extrapolated to 8.5 molal $\left[\mathrm{Na}^{+}\right]$} & 6.0488 \\
\hline 90 & 0.5187 & 0.1749 & 4.9694 \\
\hline 90 & 1.254 & 0.4458 & 5.0576 \\
\hline 90 & 2.341 & 0.8995 & 5.1791 \\
\hline 90 & 2.634 & 1.054 & 5.2262 \\
\hline 90 & 3.106 & 1.281 & 5.2764 \\
\hline 90 & 4.159 & 1.859 & 5.3980 \\
\hline \multicolumn{3}{|c|}{ extrapolated to 8.5 molal $\left[\mathrm{Na}^{+}\right]$} & 5.9118 \\
\hline 100 & 0.553 & 0.2289 & 4.9729 \\
\hline 100 & 1.277 & 0.5469 & 5.0505 \\
\hline 100 & 2.417 & 1.108 & 5.1756 \\
\hline 100 & 2.712 & 1.266 & 5.2017 \\
\hline 100 & 3.173 & 1.532 & 5.2647 \\
\hline 100 & 4.197 & 2.182 & 5.3864 \\
\hline 100 & 5.31 & 2.898 & 5.4771 \\
\hline 100 & 8.248 & 5.241 & 5.7482 \\
\hline 100 & 11.26 & 8.073 & 6.0096 \\
\hline \multicolumn{3}{|c|}{ interpolated at 8.5 molal $\left[\mathrm{Na}^{+}\right]$} & 5.7674 \\
\hline
\end{tabular}


WSRC-TR-2000-00293, Rev. 1

Table B-4. Results of Geochemist's Workbench Calculations of $\mathbf{K}_{\mathrm{f}}$ for Diaspore

\begin{tabular}{|c|c|c|c|}
\hline $\begin{array}{l}\mathbf{T} \\
\left({ }^{\circ} \mathbf{C}\right)\end{array}$ & $\begin{array}{l}{\left[\mathrm{Na}^{+}\right]} \\
(\text {molal })\end{array}$ & $\begin{array}{l}{\left[\mathrm{Al}(\mathrm{OH})_{4}{ }^{-}\right]} \\
(\text {molal })\end{array}$ & $\log \left(\mathbf{K}_{\mathbf{f}}\right.$ \\
\hline 80 & 2.2987 & 0.3912 & 4.9481 \\
\hline 80 & 2.6441 & 0.4520 & 4.9683 \\
\hline 80 & 3.0925 & 0.5356 & 4.9975 \\
\hline 80 & 4.1945 & 0.7526 & 5.0672 \\
\hline \multicolumn{3}{|c|}{ extrapolated to 8.5 molal $\left[\mathrm{Na}^{+}\right]$} & 5.4510 \\
\hline 100 & 2.3185 & 0.5577 & 4.7323 \\
\hline 100 & 2.6317 & 0.6399 & 4.7550 \\
\hline 100 & 3.0844 & 0.7561 & 4.7825 \\
\hline 100 & 4.1893 & 1.0750 & 4.8623 \\
\hline \multicolumn{3}{|c|}{ extrapolated to 8.5 molal $\left[\mathrm{Na}^{+}\right]$} & 5.2344 \\
\hline 120 & 2.3413 & 0.6628 & 4.3407 \\
\hline 120 & 2.6191 & 0.7511 & 4.3630 \\
\hline 120 & 3.1282 & 0.9218 & 4.4057 \\
\hline 120 & 4.2094 & 1.3026 & 4.4891 \\
\hline \multicolumn{3}{|c|}{ extrapolated to 8.5 molal $\left[\mathrm{Na}^{+}\right]$} & 4.8425 \\
\hline 130 & 2.3109 & 0.7512 & 4.2355 \\
\hline 130 & 2.6270 & 0.8455 & 4.2454 \\
\hline 130 & 3.1309 & 1.0281 & 4.2841 \\
\hline 130 & 3.1311 & 1.0427 & 4.2936 \\
\hline 130 & 4.1784 & 1.3770 & 4.3362 \\
\hline 130 & 5.8516 & 2.4143 & 4.5527 \\
\hline 130 & 8.9193 & 4.3325 & 4.7737 \\
\hline 130 & 12.6965 & 7.3263 & 5.0355 \\
\hline 130 & 17.6275 & 11.2823 & 5.2581 \\
\hline \multicolumn{3}{|c|}{ interpolated at 8.5 molal $\left[\mathrm{Na}^{+}\right]$} & 4.7233 \\
\hline 140 & 2.3501 & 0.8204 & 4.0897 \\
\hline 140 & 2.5960 & 0.9038 & 4.1006 \\
\hline 140 & 3.1364 & 1.1066 & 4.1371 \\
\hline 140 & 4.1733 & 1.5094 & 4.2028 \\
\hline \multicolumn{3}{|c|}{ extrapolated to 8.5 molal $\left[\mathrm{Na}^{+}\right]$} & 4.5880 \\
\hline 150 & 2.3627 & 0.9069 & 3.9925 \\
\hline 150 & 2.6450 & 1.0204 & 4.0108 \\
\hline 150 & 3.1676 & 1.2453 & 4.0512 \\
\hline 150 & 3.1260 & 1.2445 & 4.0585 \\
\hline 150 & 4.2415 & 1.7575 & 4.1396 \\
\hline 150 & 5.9201 & 2.7974 & 4.3012 \\
\hline 150 & 9.3356 & 5.0769 & 4.5256 \\
\hline 150 & 13.1634 & 8.3725 & 4.7937 \\
\hline 150 & 17.8905 & 12.5864 & 5.0307 \\
\hline 150 & 25.9954 & 19.8731 & 5.3052 \\
\hline \multicolumn{3}{|c|}{ interpolated at 8.5 molal $\left[\mathrm{Na}^{+}\right]$} & 4.4948 \\
\hline
\end{tabular}


WSRC-TR-2000-00293, Rev. 1

Table B-4. Results of Geochemist's Workbench Calculations of $\mathbf{K}_{\mathbf{f}}$ for Diaspore (continued)

$\begin{array}{lccc}\begin{array}{l}\mathbf{T} \\ \left({ }^{\circ} \mathbf{C}\right)\end{array} & \begin{array}{l}{\left[\mathbf{N a}^{+}\right]} \\ (\mathbf{m o l a l})\end{array} & \begin{array}{l}{\left[\mathbf{A l}(\mathbf{O H})_{\mathbf{4}}\right]} \\ (\mathbf{m o l a l})\end{array} & \log \left(\mathbf{K}_{\mathbf{f}}\right) \\ 160 & 2.3716 & 0.9988 & \\ 160 & 2.6217 & 1.1073 & 3.7980 \\ 160 & 3.1688 & 1.3190 & 3.8131 \\ 160 & 4.2495 & 1.8556 & 3.8297 \\ \text { extrapolated to } 8.5 \text { molal }\left[\mathrm{Na}^{+}\right] & & 3.9149 \\ & & & 4.2969 \\ 170 & 2.3846 & 1.0747 & 3.6096 \\ 170 & 2.6683 & 1.2103 & 3.6293 \\ 170 & 3.1565 & 1.4507 & 3.6649 \\ 170 & 3.1604 & 1.4820 & 3.6820 \\ 170 & 4.1320 & 2.0288 & 3.7648 \\ 170 & 5.8377 & 3.3167 & 3.9622 \\ 170 & 9.4458 & 5.8808 & 4.1650 \\ 170 & 13.4814 & 9.3198 & 4.3990 \\ 170 & 18.9928 & 14.2258 & 4.6365 \\ 170 & 26.8298 & 21.3446 & 4.8772 \\ \text { interpolated at } 8.5 \text { molal }\left[\mathrm{Na}^{+}\right] & & 4.1158\end{array}$

The next step in the procedure is to correlate the 8.5-molal log formation constants as functions of temperature, again with the use of Microsoft Excel. Linear regressions with temperature gave satisfactory results for the variation of the log formation constants for diaspore and for gibbsite above $100^{\circ} \mathrm{C}$. A quadratic regression gave better results for gibbsite below $60 \mathrm{C}$, and a cubic regression was best for gibbsite between $60^{\circ} \mathrm{C}$ and $100^{\circ} \mathrm{C}$. The regression equations are, for gibbsite below $60^{\circ} \mathrm{C}$,

$$
\log \left(\mathrm{K}_{\mathrm{f}}\right)=23.987\left(\frac{\mathrm{T}}{200}\right)^{2}-19.279\left(\frac{\mathrm{T}}{200}\right)+9.9449
$$

for gibbsite between $60^{\circ} \mathrm{C}$ and $100^{\circ} \mathrm{C}$,

$$
\log \left(\mathrm{K}_{\mathrm{f}}\right)=-71.403\left(\frac{\mathrm{T}}{200}\right)^{3}+86.553\left(\frac{\mathrm{T}}{200}\right)^{2}-37.018\left(\frac{\mathrm{T}}{200}\right)+11.561
$$

for gibbsite above $100^{\circ} \mathrm{C}$,

$$
\log \left(\mathrm{K}_{\mathrm{f}}\right)=-2.814\left(\frac{\mathrm{T}}{200}\right)+7.1756
$$

and, for diaspore,

$$
\log \left(\mathrm{K}_{\mathrm{f}}\right)=-2.9557\left(\frac{\mathrm{T}}{200}\right)+6.658
$$


Figures B-5 and B-6 illustrate the regression of the log formation constants with temperature.

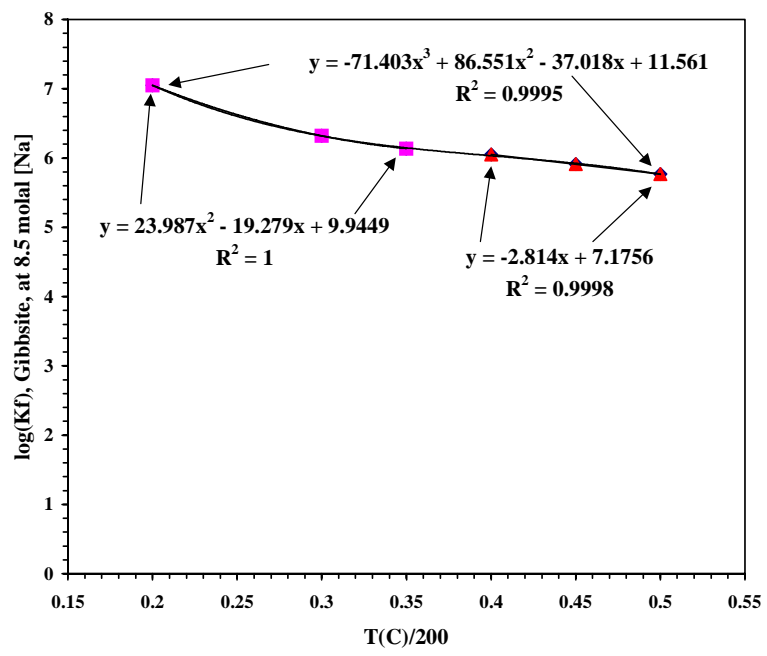

Figure B-5. Correlation of $\log \left(\mathbf{K}_{\mathrm{f}}\right)$ for Gibbsite as a Function of Temperature.

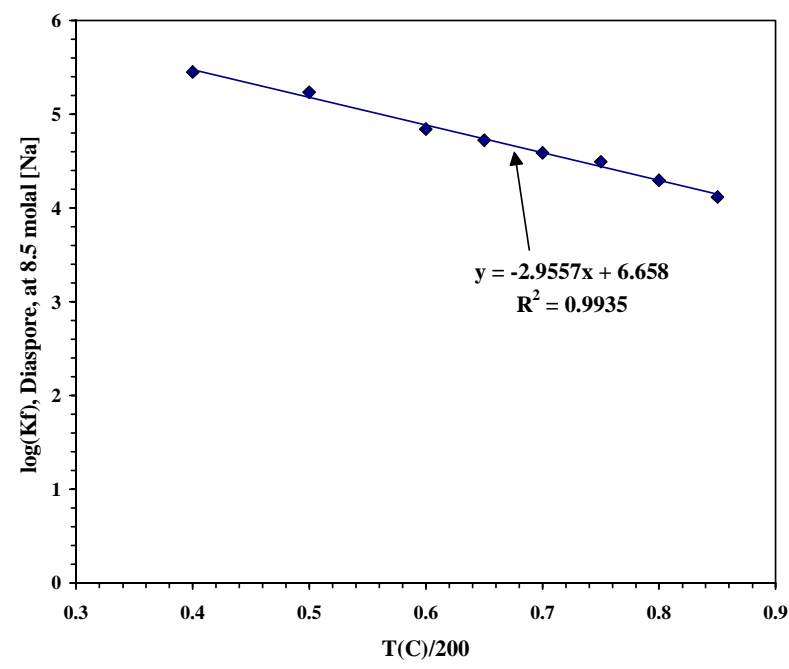

Figure B-6. Correlation of $\log \left(K_{f}\right)$ for Diaspore as a Function of Temperature.

The final step in the benchmarking procedure is to calculate the log formation constants at the temperatures specified by the THERMO database using Equations B-8 through B-11. Tables B-5 and B-6 compare the results of these calculations with the log formation constants in the THERMO database. As Table B-5 indicates, for gibbsite, the $\log$ formation constants based on the Russell et al. ${ }^{8}$ data are about equal to those in the THERMO database at $25^{\circ} \mathrm{C}$ and $60^{\circ} \mathrm{C}$, but considerably exceed the THERMO values for higher temperatures. Since larger formation constants mean higher solubilities, this implies that THERMO would underestimate gibbsite solubilities measured by Russell et al. at temperatures above $60^{\circ} \mathrm{C}$. Table B- 6 shows a similar trend for diaspore solubilities. For diaspore, THERMO underestimates the solubility slightly at $100^{\circ} \mathrm{C}$ and by a larger margin at higher temperatures. One may observe that in the THERMO database the log formation constant for gibbsite is significantly lower than that for diaspore below $100^{\circ} \mathrm{C}$ but that the two formation constants are nearly equal at $100^{\circ} \mathrm{C}$ and $150^{\circ} \mathrm{C}$. This suggests that the THERMO formation constant for gibbsite at higher temperatures might in fact be based on diaspore rather than gibbsite solubilities. 
WSRC-TR-2000-00293, Rev. 1

Table B-5. Comparison of Gibbsite Formation Constants Calculated in This Work with Those from the THERMO Database.

$\begin{array}{rcc}\mathbf{T}\left({ }^{\circ} \mathbf{C}\right) & \log \left(\mathbf{K}_{\mathbf{f}}\right) \text { this work } & \log \left(\mathbf{K}_{\mathbf{f}}\right) \text { THERMO } \\ 0 & 9.9449 & 9.5218 \\ 25 & 7.9098 & 7.9603 \\ 60 & 6.3173 & 6.2491 \\ 100 & 5.7644 & 4.7839 \\ 150 & 5.0651 & 3.4330 \\ 200 & 4.3616 & 2.3913 \\ 250 & 3.6581 & 1.4573 \\ 300 & 2.9546 & 0.3384\end{array}$

Table B-6. Comparison of Diaspore Formation Constants Calculated in This Work with Those from the THERMO Database.

$\begin{array}{rrr}\mathbf{T}\left({ }^{\circ} \mathbf{C}\right) & \log \left(\mathbf{K}_{\mathbf{f}}\right) \text { this work } & \log \left(\mathbf{K}_{\mathbf{f}}\right) \text { THERMO } \\ 0 & 500.0000 & 10.5434 \\ 25 & 500.0000 & 8.7517 \\ 60 & 500.0000 & 6.7505 \\ 100 & 5.1802 & 4.9942 \\ 150 & 4.4412 & 3.3310 \\ 200 & 3.7023 & 2.0249 \\ 250 & 2.9634 & 0.8659 \\ 300 & 2.2245 & -0.4450\end{array}$

Because the log formation constants benchmarked with the Russell et al. data differ significantly from those in the THERMO database, this study uses the benchmark values in place of the default values in the database. A straightforward substitution of log formation constants for both gibbsite and diaspore would result in a diaspore solubility that is less than the gibbsite solubility at all temperatures. If this were true, then the equilibrium model would predict that diaspore would precipitate instead of gibbsite, even at low temperatures. However, the rate of precipitation of diaspore at temperatures below $100^{\circ} \mathrm{C}$ is much slower than the precipitation rate for gibbsite, so gibbsite forms in preference to diaspore at these temperatures. To reflect the unfavorable kinetics for diaspore formation at low temperatures, the modified log formation constants for diaspore are not defined below $100^{\circ} \mathrm{C}$. (A value of 500 in the THERMO input file signifies an undefined formation constant.)

Figures B-7 and B-8 compare equilibrium constants for the Russell et al. data, adjusted to a sodium molality of 8.5 , with the equilibrium constants given by the default THERMO database. The equilibrium constants are defined in terms of the formation constants for gibbsite, diaspore, and their reaction constituents. The expressions for the $\log$ equilibrium constants are, for gibbsite,

$$
\log \left(\mathrm{K}_{\text {eq, gibbsite }}\right)=\log \left(\frac{\mathrm{K}_{\mathrm{f}, \text { gibbsite }} \mathrm{K}_{\mathrm{f}, \mathrm{OH}^{-}}}{\mathrm{K}_{\mathrm{f}, \mathrm{Al}(\mathrm{OH})_{4}^{-}}}\right)
$$


and, for diaspore,

$$
\log \left(\mathrm{K}_{\text {eq, diaspore }}\right)=\log \left(\frac{\mathrm{K}_{\mathrm{f}, \text { diaspore }} \mathrm{K}_{\mathrm{f}, \mathrm{H}_{2} \mathrm{O}} \mathrm{K}_{\mathrm{f}, \mathrm{OH}^{-}}}{\mathrm{K}_{\mathrm{f}, \mathrm{Al}(\mathrm{OH})_{4}^{-}}}\right)
$$

where the subscript eq refers to the equilibrium constant and the subscript $f$ denotes the formation constants. The sign of the equilibrium constants is set so that higher values of these constants denote greater solubility.

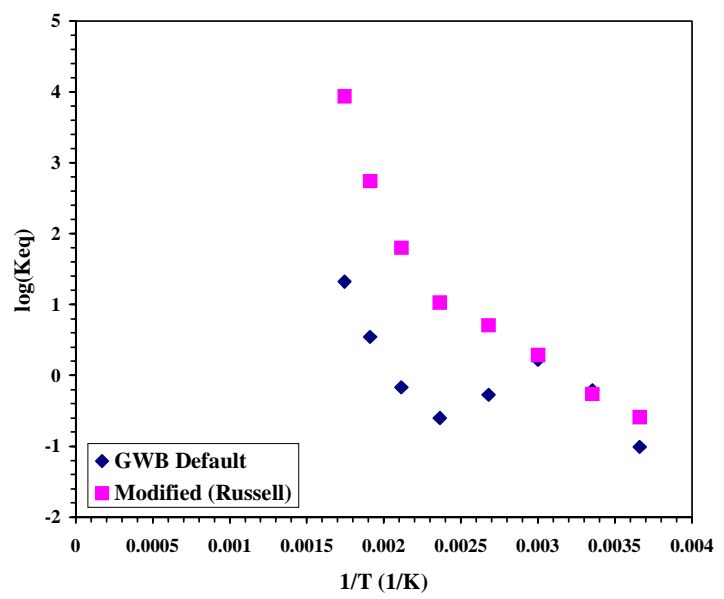

Figure B-7. Comparison of the Default THERMO and Russell et. al Solubility Constants for Gibbsite.

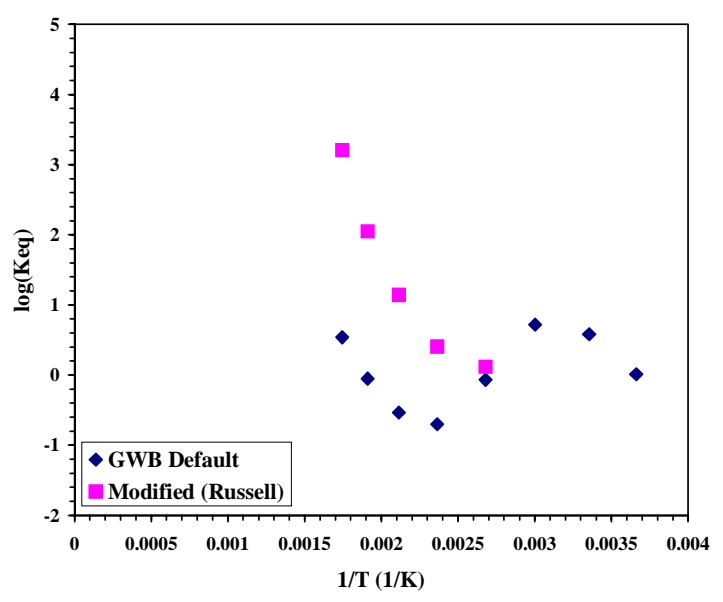

Figure B-8. Comparison of the Default THERMO and Russell et. al Solubility Constants for Diaspore.

As Figure B-7 shows, the default and modified THERMO databases predict nearly identical gibbsite solubilities at $60^{\circ} \mathrm{C}$ and below. Above this temperature, the solubility given by the modified database exceeds that predicted by the default database. The diaspore solubilities for the two databases, depicted by Figure B-8, are similar at $100^{\circ} \mathrm{C}$, but the As Figure B-8 indicates, the modified database yields about the same diaspore solubility as the default database at $100^{\circ} \mathrm{C}$, but significantly diaspore greater solubilities at higher temperatures. The temperature variations of both the gibbsite and the diaspore solubilities for the default database have "kinks" at about $100^{\circ} \mathrm{C}$. These kinks suggest that there are phase transformation embedded in the original THERMO database. The solubility changes in the modified database remove these apparent phase transformations.

\section{Modeling of Sodium Aluminosilicate Gel $\left(\mathrm{NAS}_{\mathrm{gel}}\right)$ and Zeolite-A Solubilities}

The THERMO database lacks formation constants for sodalites, cancrinites, and the zeolites and zeolite precursors that form these minerals. As Section 2.3 explains, the first steps in the paragenesis of sodalites and cancrinites are the formation of an amorphous aluminosilicate, followed by the formation of Zeolite-A. Ejaz and Jones ${ }^{10}$ measured solubilities of an aluminosilicate gel $\left(\mathrm{NAS}_{\mathrm{gel}}\right)$ and Zeolite- $\mathrm{A}$ in 3.02, 3.32, 3.89, and 4.39 
molar sodium hydroxide solutions. To ensure that they measured the correct equilibrium, they seeded the solutions with either a washed precipitate of the gel or with Zeolite-A purchased from a catalyst manufacturer. They checked the composition of the seeded materials with XRD.

Ejaz and Jones ${ }^{10}$ measured solubilities at $30^{\circ} \mathrm{C}, 50^{\circ} \mathrm{C}, 65^{\circ} \mathrm{C}$, and $80^{\circ} \mathrm{C}$. Tables $\mathrm{B}-7$ and B-8 list their solubility data for $\mathrm{NAS}_{\mathrm{gel}}$ and Zeolite-A, respectively. These data have been converted from molar to molal units, based on a reference temperature of $25^{\circ} \mathrm{C}$. The last column in these tables indicates whether or not the data are used in the solubility modeling. A discussion of the selection of these data follows.

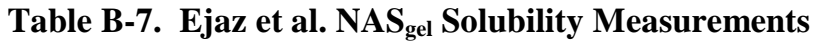

$\begin{array}{lllll}\begin{array}{l}\mathbf{T} \\ \left({ }^{\circ} \mathbf{C}\right)\end{array} & \begin{array}{l}{\left[\mathbf{N a}^{+}\right]} \\ (\mathbf{m o l a l})\end{array} & \begin{array}{l}{\left[\mathbf{A l}(\mathbf{O H})_{\mathbf{4}}{ }^{-}\right]} \\ (\mathbf{m o l a l})\end{array} & \begin{array}{l}{[\mathbf{S i}]} \\ (\mathbf{m o l a l})\end{array} & \text { Used in Analysis } \\ 80 & 3.0368 & 0.02911 & 0.03881 & \text { No } \\ 80 & 3.3425 & 0.03355 & 0.04549 & \text { No } \\ 80 & 3.9299 & 0.04156 & 0.05773 & \text { No } \\ 80 & 4.4491 & 0.02233 & 0.02996 & \text { No } \\ 65 & 3.0368 & 0.04166 & 0.05698 & \text { No } \\ 65 & 3.3425 & 0.03531 & 0.04669 & \text { No } \\ 65 & 3.9299 & 0.04754 & 0.06822 & \text { No } \\ 65 & 4.4491 & 0.03331 & 0.04589 & \text { No } \\ 50 & 3.0368 & 0.03891 & 0.05282 & \text { Yes } \\ 50 & 3.3425 & 0.04288 & 0.06013 & \text { No } \\ 50 & 3.9299 & 0.05130 & 0.07157 & \text { No } \\ 50 & 4.4491 & 0.04388 & 0.06089 & \text { Yes } \\ 30 & 3.0368 & 0.03469 & 0.04679 & \text { Yes } \\ 30 & 3.3425 & 0.04174 & 0.05683 & \text { No } \\ 30 & 3.9299 & 0.05033 & 0.06794 & \end{array}$


WSRC-TR-2000-00293, Rev. 1

Table B-8. Ejaz et al. Zeolite-A Solubility Measurements

$\begin{array}{lllll}\begin{array}{l}\mathbf{T} \\ \left({ }^{\circ} \mathbf{C}\right)\end{array} & \begin{array}{l}{\left[\mathbf{N a}^{+}\right]} \\ (\mathbf{m o l a l})\end{array} & \begin{array}{l}{\left[\mathbf{A l}(\mathbf{O H})_{\mathbf{4}}{ }^{-}\right]} \\ (\mathbf{m o l a l})\end{array} & \begin{array}{l}{[\mathbf{S i}]} \\ (\mathbf{m o l a l})\end{array} & \text { Used in Analysis } \\ 80 & 3.0368 & 0.01293 & 0.01412 & \\ 80 & 3.3425 & 0.01372 & 0.01528 & \text { No } \\ 80 & 3.9299 & 0.01735 & 0.01943 & \text { Yes } \\ 80 & 4.4491 & 0.01937 & 0.02152 & \text { Yes } \\ 65 & 3.0368 & 0.00891 & 0.00890 & \text { No } \\ 65 & 3.3425 & 0.01247 & 0.01336 & \text { No } \\ 65 & 3.9299 & 0.01361 & 0.01478 & \text { No } \\ 65 & 4.4491 & 0.01516 & 0.01634 & \text { No } \\ 50 & 3.0368 & 0.00924 & 0.00950 & \text { No } \\ 50 & 3.3425 & 0.01059 & 0.01125 & \text { Yes } \\ 50 & 3.9299 & 0.01335 & 0.01436 & \text { Yes } \\ 50 & 4.4491 & 0.01526 & 0.01673 & \text { No } \\ 30 & 3.0368 & 0.00431 & 0.00327 & \text { No } \\ 30 & 3.3425 & 0.00518 & 0.00531 & \text { No } \\ 30 & 3.9299 & 0.0085 & 0.00899 & \text { No } \\ 30 & 4.4491 & 0.00823 & 0.00842 & \end{array}$

Figures B-9 and B-10 are reproductions of contour plots from the Ejaz and Jones paper that show the variations of silicate and aluminate solubilities with temperature and $[\mathrm{NaOH}]$. As these plots demonstrate, the solubility of $\mathrm{NAS}_{\mathrm{gel}}$ considerably exceeds the Zeolite-A solubility. The solubility of Zeolite-A increases with both increasing temperature and increasing $[\mathrm{NaOH}]$. At $30^{\circ} \mathrm{C}$ and $50^{\circ} \mathrm{C}$, the solubility of $\mathrm{NAS}_{\text {gel }}$ also rises as the temperature and $[\mathrm{NaOH}]$ rise. However, at higher temperatures, the $\mathrm{NAS}_{\text {gel }}$ solubility drops as both the temperature and $[\mathrm{NaOH}]$ increase. Ejaz and Jones attribute this decrease in the $\mathrm{NAS}_{\text {gel }}$ solubility to crystallization of Zeolite-A. They explained that the rate of Zeolite-A formation becomes significant in the time scale in which the measurements were made at the $65^{\circ} \mathrm{C}$ and $80^{\circ} \mathrm{C}$ temperatures. The crystallization of Zeolite-A would reduce the solubility of aluminates and silicates toward the equilibrium value for the precipitation of Zeolite-A.

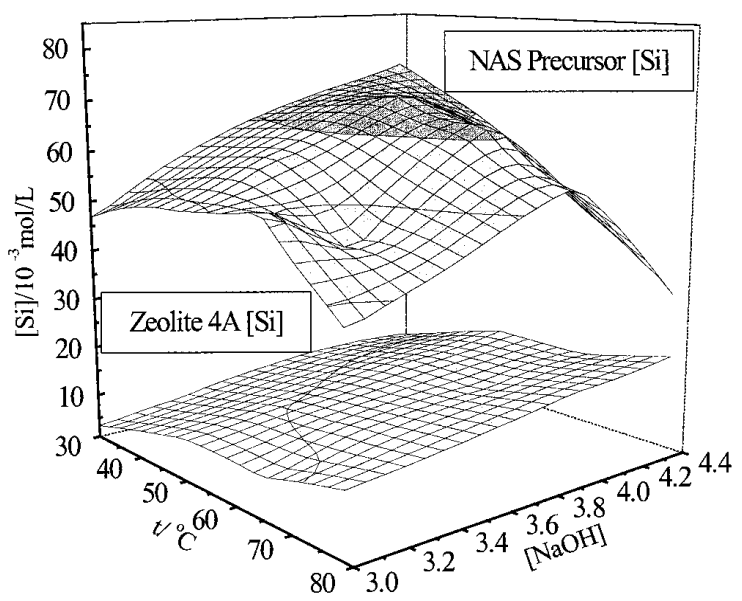

Figure B-9. Ejaz and Jones Silicate Solubilities as a Function of Temperature and [ $\mathrm{NaOH}]$.

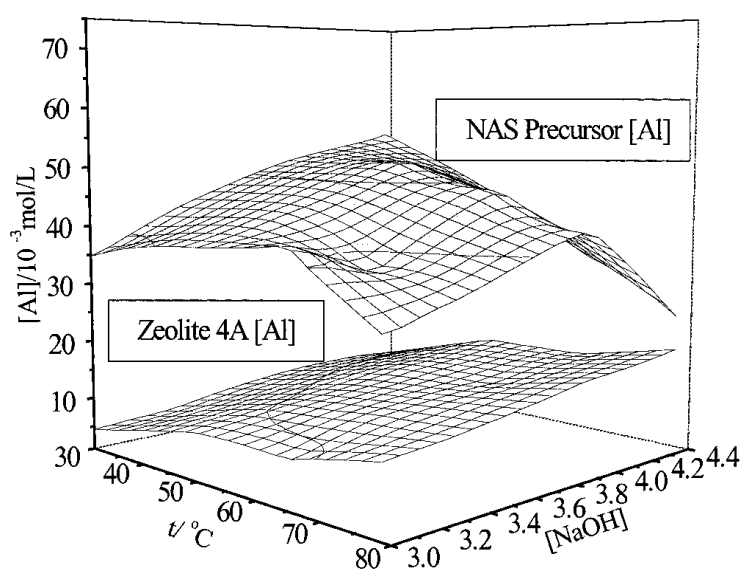

Figure B-10. Ejaz and Jones Aluminate Solubilities as a Function of Temperature and [ $\mathrm{NaOH}]$. 
The apparent crystallization of Zeolite-A from the $\mathrm{NAS}_{\text {gel }}$ solutions limits the selection of data that can be used to extrapolate the solubility model to higher sodium concentrations and higher temperatures. The contour plots for $\mathrm{NAS}_{\mathrm{gel}}$ show that the only region where the solubility increases with increasing temperature and $[\mathrm{NaOH}]$, as should be expected, is for temperatures of $50^{\circ} \mathrm{C}$ and lower and concentrations of 3.89 molar and below. From this subset, the data selected for modeling was at temperatures of $30^{\circ} \mathrm{C}$ and $50^{\circ} \mathrm{C}$ and concentrations of 3.32 molar and 3.89 molar. The data selected for modeling the Zeolite-A solubility was at temperatures of $50^{\circ} \mathrm{C}$ and $80^{\circ} \mathrm{C}$ and concentrations of 3.89 and 4.39 molar. This subset appeared to capture the general trends of the Zeolite-A solubility with temperature and concentrations variations the best. The data at $65^{\circ} \mathrm{C}$ were skipped because the measured concentrations at this temperature were lower than would be predicted by the $50^{\circ} \mathrm{C}$ and $80^{\circ} \mathrm{C}$ data.

An inspection of the variation of solubilities with $[\mathrm{Na}]$ revealed that the apparent aluminosilicate solubility product, $[\mathrm{Al}][\mathrm{Si}]$, is proportional to $[\mathrm{Na}]^{2}$. This observation seems to confirm the reaction stoichiometry for natural (chloride) sodalite and hydroxysodalite proposed by Gasteiger and Frederick. ${ }^{11}$ They determined that the equilibrium constant for the formation of sodalites is inversely proportional to $\left[\mathrm{OH}^{-}\right]^{3}$. The formation constants for both $\mathrm{NAS}_{\mathrm{gel}}$ and Zeolite-A should follow the same proportionality with respect to $\left[\mathrm{OH}^{-}\right]$, since both precipitates are sodalite precursors. In addition, the $\mathrm{NAS}_{\mathrm{gel}}$ and Zeolite-A formation constants should be proportional to [ $\left.\mathrm{Na}^{+}\right]$, due to the approximate $1: 1$ stoichiometric ratio of sodium with respect to aluminum and silicon in these substances. Because $\left[\mathrm{OH}^{-}\right]$is proportional to $\left[\mathrm{Na}^{+}\right]$in strongly basic solutions, the formation constants for $\mathrm{NAS}_{\text {gel }}$ and Zeolite-A should be inversely proportional to $\left[\mathrm{Na}^{+}\right]^{2}$. It follows that the solubility product should be directly proportional to $\left[\mathrm{Na}^{+}\right]^{2}$.

This proportionality holds for both $\mathrm{NAS}_{\text {gel }}$ and Zeolite-A, as Figures B-11 and B-12 illustrate. These figures present Microsoft Excel regression equations for the solubility product as a function of $[\mathrm{Na}]$.

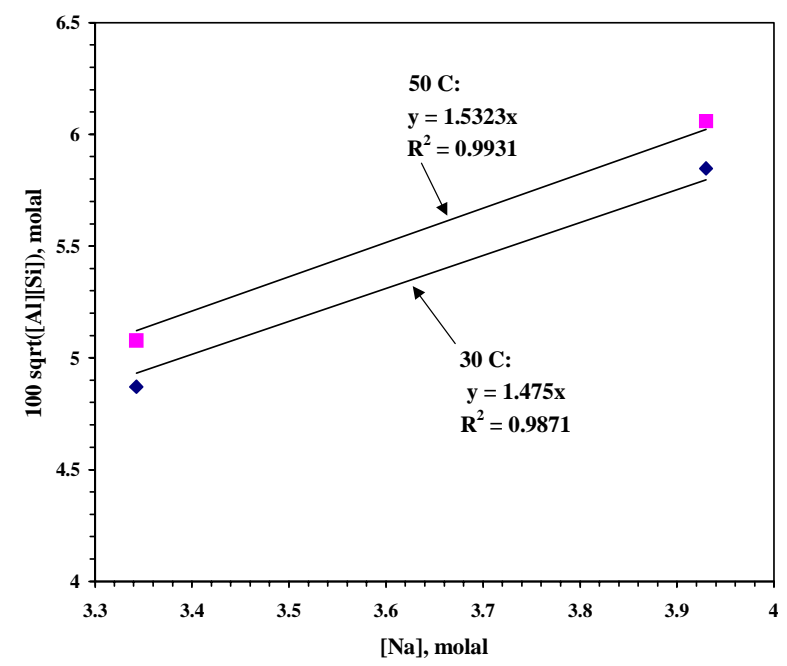

Figure B-11. Variation of NAS $_{\text {gel }}$ Solubility Product with Sodium Concentration.

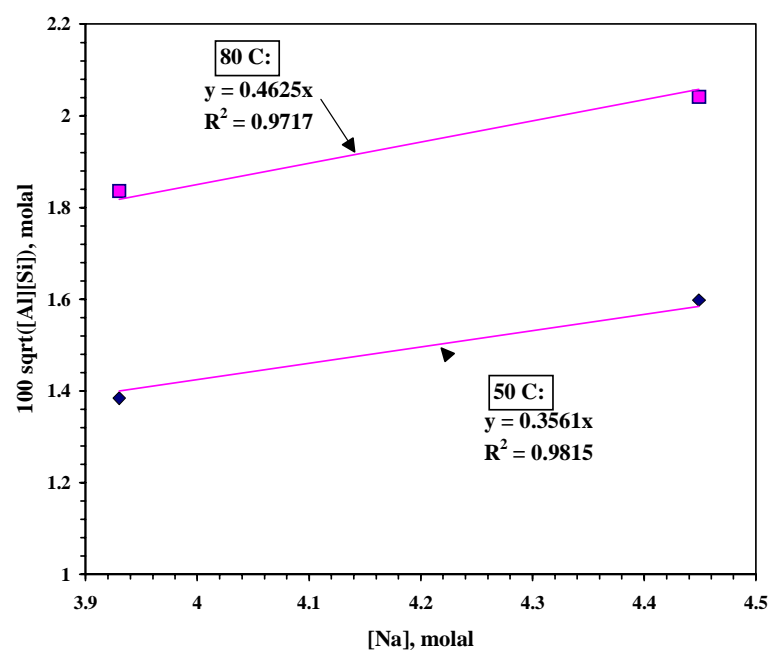

Figure B-12. Variation of Zeolite-A Solubility Product with Sodium Concentration. 


\section{WSRC-TR-2000-00293, Rev. 1}

The regression equations shown in these figures are:

$$
\begin{aligned}
& \text { for } \mathrm{NAS}_{\mathrm{gel}} \text { at } 30^{\circ} \mathrm{C}, 100 \sqrt{[\mathrm{Al}][\mathrm{Si}]}=1.475[\mathrm{Na}] \\
& \text { for } \mathrm{NAS}_{\mathrm{gel}} \text { at } 50^{\circ} \mathrm{C}, 100 \sqrt{[\mathrm{Al}][\mathrm{Si}]}=1.5323[\mathrm{Na}] \text {, } \\
& \text { for Zeolite-A at } 50^{\circ} \mathrm{C}, 100 \sqrt{[\mathrm{Al}][\mathrm{Si}]}=0.3561[\mathrm{Na}] \text {, } \\
& \text { and for Zeolite-A at } 80^{\circ} \mathrm{C}, 100 \sqrt{[\mathrm{Al}][\mathrm{Si}]}=0.4625[\mathrm{Na}]
\end{aligned}
$$

where all concentrations are in molal units.

The modeling of the temperature variability of the solubility product requires an additional Microsoft Excel regression, this time as a function of the inverse temperature. The temperature regression follows the calculation of extrapolated aluminate and silicate solubilities at $[\mathrm{Na}]=8.5$ molal, using Equations B-14 through B-17. Figures B-13 and B-14 are Arrhenius plots that portray the variation of the $\mathrm{NAS}_{\text {gel }}$ and Zeolite-A solubility products with temperature. (Figure B-13 is based on extrapolated solubilities at $30^{\circ} \mathrm{C}$ $(303 \mathrm{~K})$ and $50^{\circ} \mathrm{C}(323 \mathrm{~K})$, while Figure B-14 is based on extrapolated solubilities at $50^{\circ} \mathrm{C}(323 \mathrm{~K})$ and $80^{\circ} \mathrm{C}(353 \mathrm{~K})$. Both solubility products increase as the temperature increases; the solubility product for Zeolite-A increases by a proportionally greater amount.

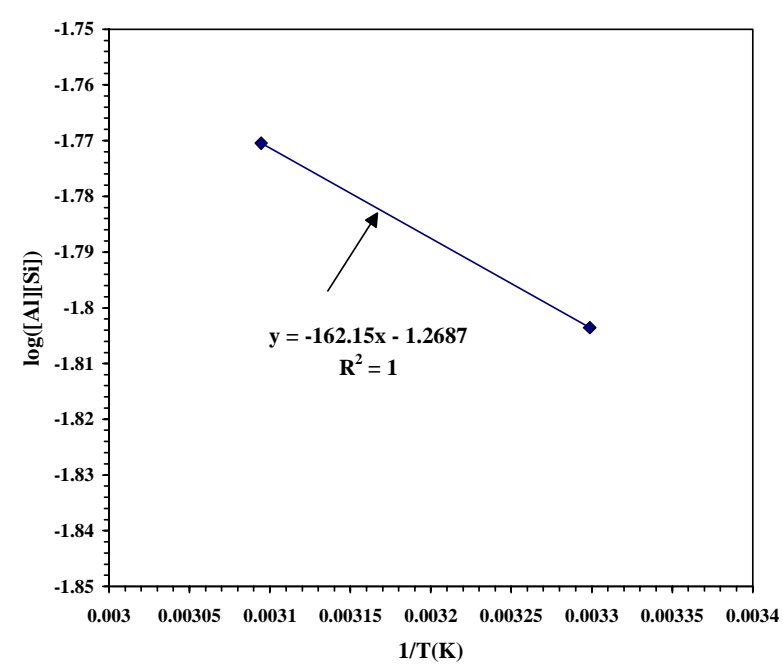

Figure B-13. Variation of NAS gel $_{\text {Solubility Product }}$ with Temperature when $[\mathrm{Na}+]=8.5$ molal.

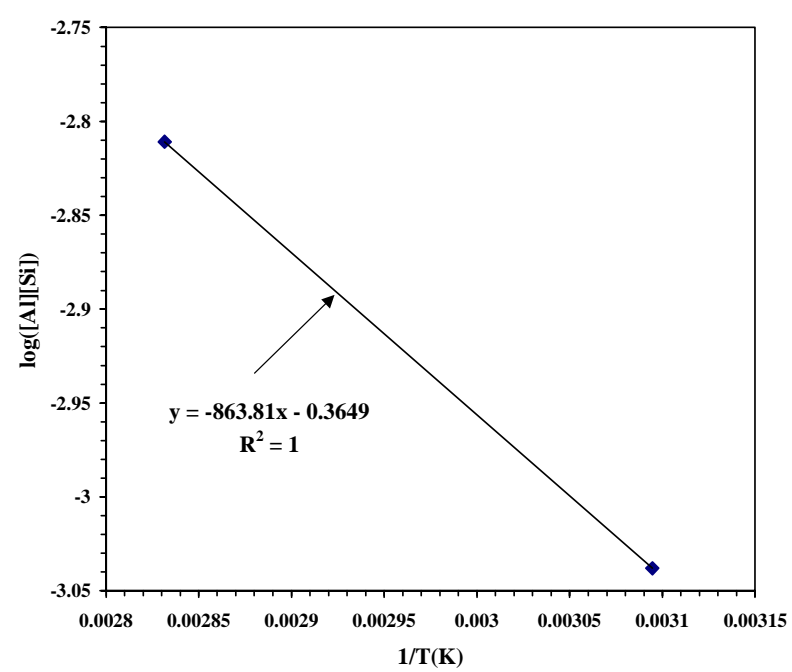

Figure B-14. Variation of Zeolite-A Solubility Product with Temperature when $[\mathrm{Na}+]=8.5$ molal. 


\section{WSRC-TR-2000-00293, Rev. 1}

The Arrhenius equations given by these figures, in terms of concentrations and temperatures, are:

$$
\text { for } \mathrm{NAS}_{\mathrm{gel}}, \log ([\mathrm{Al}][\mathrm{Si}])=\frac{-162.15}{\mathrm{~T}}-1.2687
$$

$$
\text { and for Zeolite-A, } \log ([\mathrm{Al}][\mathrm{Si}])=\frac{-863.81}{\mathrm{~T}}-0.3649
$$

where $\mathrm{T}$ is in $\mathrm{K}$ and [Al] and [Si] are in molal units.

The final step in modeling the NASgel and Zeolite-A solubilities is to calculate log formation constants for GWB, using the REACT program. The input for these calculations consists of the assumed sodium concentration of 8.5 molal, plus silicate and aluminate concentrations based on the solubility products calculated from Equations B-14 through B-19. In the calculation of individual silicate and aluminate concentrations from the solubility products, the molar Si:Al ratio was kept constant at the average stoichiometry measured by Ejaz and Jones. ${ }^{10}$ Tables B-9 and B-10 list the REACT input and output for the calculation of the formation constants. As described in the sections on sodium aluminate, gibbsite, and diaspore, the modified THERMO database contains the $\log$ formation constants listed in these tables

Table B-9. Extrapolated Solubilities and Formation Constants for NAS at $\left[\mathrm{Na}^{+}\right]=8.5$ molal.

$\begin{array}{rlllll}\begin{array}{l}\mathbf{T} \\ \left({ }^{\circ} \mathbf{C}\right)\end{array} & \begin{array}{l}\mathbf{K}_{\text {sp }} \\ (\mathbf{m o l a l})\end{array} & \begin{array}{l}{\left[\mathbf{S i O}_{2}(\mathbf{a q})\right]} \\ (\mathbf{m o l a l})\end{array} & \begin{array}{l}{\left[\mathbf{A l}(\mathbf{O H}){ }_{4}{ }^{-}\right]} \\ (\mathbf{m o l a l})\end{array} & {\left[\mathrm{Na}^{+}\right]} & \log \left(\mathbf{K}_{\mathbf{f}}\right) \\ & & & & & \\ 0 & 0.01373 & 0.13751 & 0.09985 & 8.5 & 177.6823 \\ 25 & 0.01540 & 0.14562 & 0.10574 & 8.5 & 165.0373 \\ 60 & 0.01756 & 0.15552 & 0.11293 & 8.5 & 122.3779 \\ 100 & 0.01980 & 0.16515 & 0.11992 & 8.5 & 109.7334 \\ 150 & 0.02229 & 0.17521 & 0.12722 & 8.5 & 97.1001 \\ 200 & 0.02447 & 0.18357 & 0.13329 & 8.5 & 79.3499 \\ 250 & 0.02639 & 0.19062 & 0.13841 & 8.5 & 54.2551 \\ 300 & 0.02808 & 0.19665 & 0.14279 & 8.5 & 24.3518\end{array}$

Table B-10. Extrapolated Solubilities and Formation Constants for Zeolite A at $\left[\mathrm{Na}^{+}\right]=8.5$ molal.

$\begin{array}{rllllr}\begin{array}{l}\text { T } \\ \left({ }^{\circ} \mathbf{C}\right)\end{array} & \begin{array}{l}\mathbf{K}_{\text {sp }} \\ \left(\mathbf{m o l a l}^{2}\right)\end{array} & \begin{array}{l}{[\mathbf{S i O}} \\ (\mathbf{m o l a l})\end{array} & \left.\begin{array}{l}{[\mathbf{A l}(\mathbf{O H})} \\ (\mathbf{m o l a l})\end{array}{ }^{-}\right] & {\left[\mathbf{N a}^{+}\right]} & \log \left(\mathbf{K}_{\mathbf{f}}\right) \\ 0 & 0.000297 & 0.01808 & 0.01643 & 8.5 & 174.1143 \\ 25 & 0.000547 & 0.02453 & 0.02229 & 8.5 & 147.0798 \\ 60 & 0.001102 & 0.03483 & 0.03164 & 8.5 & 121.4874 \\ 100 & 0.002090 & 0.04797 & 0.04358 & 8.5 & 110.3860 \\ 150 & 0.003924 & 0.06572 & 0.05971 & 8.5 & 99.3594 \\ 200 & 0.006448 & 0.08425 & 0.07654 & 8.5 & 83.0548 \\ 250 & 0.009637 & 0.10299 & 0.09357 & 8.5 & 60.4177 \\ 300 & 0.013427 & 0.12157 & 0.11045 & 8.5 & 32.6036\end{array}$




\section{WSRC-TR-2000-00293, Rev. 1}

\section{Modeling of Sodalite Solubilities}

In addition to $\mathrm{NAS}_{\text {gel }}$ and Zeolite-A, the modified database includes solubilities for a generalized sodalite/cancrinite, called "mixed zeolite" and assigned the chemical formula for Zeolite-A, and hydroxysodalite. These solubilities are based on measurements of simulants of pulping solutions used in the Kraft paper process, performed by Gasteiger and Frederick ${ }^{11}$ and Park and Englezos. ${ }^{12}$ The mixed zeolite solubility model pertains to "green liquor" measurements performed by Gasteiger and Frederick, and the hydroxysodalite solubility model is based on the measurements of Park and Englezos. Both sets of experiments measured precipitations from supersaturated solutions. XRD analyses identified the precipitates as either zeolites, sodalites, or cancrinites.

The procedure for evaluating the log formation constant for these tests is similar to that previously described for $\mathrm{NAS}_{\text {gel }}$ and Zeolite-A. The primary difference is that both sets of measurements were restricted to a single temperature, $95^{\circ} \mathrm{C}$, so a direct extrapolation of the variation of solubility with temperature is not possible. Instead, the temperature variation of the solubility is based on the Arrhenius coefficients for the solubilities of $\mathrm{NAS}_{\text {gel }}$ and Zeolite-A. To account for the difference between measured sodium concentrations and the evaporator concentration of 8.5 molal, the analysis uses a multiplicative factor for every component of the measurement solutions. This factor is simply the ratio between 8.5 molal and the measured sodium concentration. Use of this factor is equivalent to the approximation that the aluminate-silicate solubility product is proportional to $[\mathrm{Na}]^{2}$.

The remainder of this section describes the analysis of the Gasteiger and Frederick data and then the analysis of the Park and Englezos data. XRD analyses of the precipitates from several of the Gasteiger and Frederick experiments showed the presence of a mixture of Zeolite-A and a cancrinite, as summarized in Table B-11. As this table indicates, only four of these tests generated a precipitate that had an aluminosilicate as a major component; the model for mixed zeolite is based on those tests.

Table B-11. Experiment Numbers and X-Ray Diffraction Identifications for Gasteiger and Frederick Solubility Data

$\begin{array}{cclll}\text { Run ID No. } & \text { ICDD-JCPDS No. } & \text { Identification } & \text { Chemical Formula } & \text { Used in Analysis } \\ 335 & 42-0216 & \text { Zeolite-A } & \mathrm{Na}_{6}\left[\mathrm{AlSiO}_{4}\right]_{6} \bullet 4 \mathrm{H}_{2} \mathrm{O} & \mathrm{No} \\ 209 & 38-0021 & \text { Cancrinite } & \mathrm{Na}_{8} \mathrm{Al}_{6} \mathrm{Si}_{6} \mathrm{O}_{24}\left(\mathrm{NO}_{2}\right)_{2} \bullet 3 \mathrm{H}_{2} 0 & \mathrm{Yes} \\ 213 & 38-0021 & \text { Cancrinite } & \mathrm{Na}_{8} \mathrm{Al}_{6} \mathrm{Si}_{6} \mathrm{O}_{24}\left(\mathrm{NO}_{2}\right)_{2} \bullet 3 \mathrm{H}_{2} \mathrm{O} & \mathrm{Yes} \\ 455 & 38-0021 & \text { Cancrinite } & \mathrm{Na}_{8} \mathrm{Al}_{6} \mathrm{Si}_{6} \mathrm{O}_{24}\left(\mathrm{NO}_{2}\right)_{2} \bullet 3 \mathrm{H}_{2} \mathrm{O} & \text { No }\end{array}$

Table B-12 summarizes the results of the Gasteiger and Frederick solubility experiments, as well as the REACT calculations of the log formation constants. This table presents both measured results at a sodium molality of 4.6 and extrapolated calculations at the estimated evaporator sodium molality of 8.5. As the results in Table B-12 indicate, the formation constants for these tests exhibit a considerably variation. Because of this variability, the modeling is restricted to the two tests giving intermediate values for this constant. The other two tests also were inconsistent in other ways. One test, No. 335, 
generated a precipitate that contained primarily Zeolite-A, whereas the precipitates from the other tests were mostly cancrinite. The other test, No. 455, began with an excess of silicate instead of an excess of aluminate. This composition makes it a poor simulant for the evaporator solutions, which have relative high aluminate and low silicate concentrations.

Table B-12. Gasteiger and Frederick Solubility Data

\begin{tabular}{|c|c|c|c|c|c|c|c|c|}
\hline ID No. & $\begin{array}{l}\mathbf{T} \\
\left({ }^{\circ} \mathbf{C}\right)\end{array}$ & $\begin{array}{l}{\left[\mathrm{Na}^{+}\right]} \\
\text {(molal) }\end{array}$ & $\begin{array}{l}{\left[\mathrm{CO3}^{2-}\right]} \\
\text { (molal) }\end{array}$ & $\begin{array}{l}{\left[\mathrm{HS}^{-}\right]} \\
\text {(molal)_ }\end{array}$ & $\begin{array}{l}{\left[\mathrm{SO}^{2-}\right]} \\
\text { (molal) }\end{array}$ & $\begin{array}{l}{[\mathrm{Si}]} \\
\text { (molal) }\end{array}$ & $\begin{array}{l}{\left[\mathrm{Al}(\mathrm{OH})_{4}{ }^{-}\right]} \\
\text {(molal) }\end{array}$ & $\log \left(K_{f}\right)$ \\
\hline \multicolumn{9}{|c|}{ Measured } \\
\hline 335 & 95 & 4.6039 & 1.5698 & 0.4636 & 0.02107 & 0.00145 & 0.01278 & 106.9409 \\
\hline 209 & 95 & 4.6039 & 1.5698 & 0.4636 & 0.02107 & 0.00610 & 0.01077 & 113.5797 \\
\hline 213 & 95 & 4.6039 & 1.5698 & 0.4636 & 0.02107 & 0.00193 & 0.02114 & 111.1471 \\
\hline 455 & 95 & 4.6039 & 1.5698 & 0.4636 & 0.02107 & 0.13829 & 0.00070 & 116.9995 \\
\hline \multicolumn{9}{|c|}{ Extrapolated to $\left[\mathrm{Na}^{+}\right]=8.5$ molal } \\
\hline 335 & 95 & 8.5 & 2.8982 & 0.8558 & 0.03890 & 0.00267 & 0.02359 & 112.5206 \\
\hline 209 & 95 & 8.5 & 2.8982 & 0.8558 & 0.03890 & 0.01126 & 0.01989 & 119.1557 \\
\hline 213 & 95 & 8.5 & 2.8982 & 0.8558 & 0.03890 & 0.00357 & 0.03904 & 116.7271 \\
\hline 455 & 95 & 8.5 & 2.8982 & 0.8558 & 0.03890 & 0.25532 & 0.00129 & 122.5247 \\
\hline
\end{tabular}

The calculation of the log formation constant for the modified database is based on the average value for the two analyzed tests at $95^{\circ} \mathrm{C}$. Because the mixed zeolite solubility at this temperature lies between the solubilities of $\mathrm{NAS}_{\mathrm{gel}}$ and Zeolite-A, the analysis uses a weighted average Arrhenius factor. The appropriate weighting factor is assumed to be the difference between the $\log$ formation constants for mixed zeolite and NAS $\mathrm{Sel}_{\text {gel }}$, divided by the difference between the log formation constants for Zeolite-A and NAS gel. $_{\text {. Table }}$ B-13 summarizes this calculation. As this table shows, when the model calculated that the solution is saturated with mixed zeolite, the log formation constant for Zeolite-A is positive, indicating that the solution is supersaturated with Zeolite-A, and the log formation constant for $\mathrm{NAS}_{\mathrm{gel}}$ is negative, indicating undersaturation. The results show that log formation constant for mixed zeolite is about halfway between the values for $\mathrm{NAS}_{\text {gel }}$ and Zeolite-A, so the Arrhenius factor approximately equals the average of the factors for $\mathrm{NAS}_{\mathrm{gel}}$ and Zeolite-A.

Table B-13. Evaluation of Arrhenius Factor for Temperature Depedence of Mixed Zeolite Solubility

\begin{tabular}{|c|c|c|c|c|}
\hline Run ID No. & $\begin{array}{l}\log (\mathrm{Kf}) \\
\text { Mixed Zeolite }\end{array}$ & $\begin{array}{l}\log (K f) \\
\text { NAS }_{\text {gel }}\end{array}$ & $\begin{array}{l}\log (\mathbf{K f}) \\
\text { Zeolite-A }\end{array}$ & $\begin{array}{l}\text { Weighting factor } \\
\text { for Zeolite-A }\end{array}$ \\
\hline 209 & 0.0 & -5.9175 & 8.2352 & 0.4181 \\
\hline 213 & 0.0 & -9.3377 & 5.8066 & 0.6166 \\
\hline Average & & & & 0.5173 \\
\hline \multirow{3}{*}{\multicolumn{3}{|c|}{$\begin{array}{l}\text { Arrhenius factor, } \text { NAS }_{\text {gel }} \\
\text { Arrhenius factor, Zeolite-A } \\
\text { Arrhenius factor, Mixed Zeo }\end{array}$}} & -863.61 & \\
\hline & & & -162.15 & \\
\hline & & & -525.05 & \\
\hline
\end{tabular}

With this approximated Arrhenius factor, the calculation of log formation constants at the temperatures specified for the THERMO database can proceed. The calculation procedure is identical to that used for the Ejaz and Jones data. This procedure calls for 
the calculation of the solubility product, followed by the calculation of silicate and aluminate concentrations at saturation. The calculation uses the average ratio of silicate to aluminate concentrations for the two analyzed tests. Table B-14 presents the results of these analyses and the subsequent REACT calculations of the log formation constants.

Table B-14. Extrapolated Solubilities and Formation Constants for Mixed Zeolite at $\left[\mathrm{Na}^{+}\right]=8.5$ molal.

\begin{tabular}{|c|c|c|c|c|c|c|c|c|}
\hline $\begin{array}{l}\mathbf{T} \\
\left({ }^{\circ} \mathbf{C}\right)\end{array}$ & $\begin{array}{l}{\left[\mathrm{Na}^{+}\right]} \\
(\mathrm{molal})\end{array}$ & $\begin{array}{l}{\left[\mathrm{CO}_{3}{ }^{2-}\right]} \\
(\mathrm{molal})\end{array}$ & $\begin{array}{l}{\left[\mathrm{HS}^{-}\right]} \\
\text {(molal) }\end{array}$ & $\begin{array}{l}{\left[\mathrm{SO}_{4}{ }^{2-}\right]} \\
(\mathrm{molal})\end{array}$ & $\begin{array}{l}\mathbf{K}_{\mathrm{sp}} \\
\left(\mathrm{molal}^{2}\right)\end{array}$ & $\begin{array}{l}{[\mathrm{Si}]} \\
(\text { molal })\end{array}$ & $\begin{array}{l}{\left[\mathrm{Al}(\mathrm{OH})_{4}{ }^{-}\right]} \\
(\text {molal })\end{array}$ & $\log \left(\mathbf{K}_{\mathrm{f}}\right)$ \\
\hline 0 & 8.5 & 2.8982 & 0.8558 & 0.03890 & $5.638 \mathrm{E}-05$ & 0.004306 & 0.013095 & 184.3498 \\
\hline 25 & 8.5 & 2.8982 & 0.8558 & 0.03890 & $8.172 \mathrm{E}-05$ & 0.005184 & 0.015765 & 155.5662 \\
\hline 60 & 8.5 & 2.8982 & 0.8558 & 0.03890 & $1.2513 \mathrm{E}-04$ & 0.006414 & 0.019507 & 128.8747 \\
\hline 100 & 8.5 & 2.8982 & 0.8558 & 0.03890 & $1.8463 \mathrm{E}-04$ & 0.007792 & 0.023695 & 117.6991 \\
\hline 150 & 8.5 & 2.8982 & 0.8558 & 0.03890 & $2.7074 \mathrm{E}-04$ & 0.009435 & 0.028694 & 106.9683 \\
\hline 200 & 8.5 & 2.8982 & 0.8558 & 0.03890 & $3.6616 \mathrm{E}-04$ & 0.010973 & 0.033370 & 90.1806 \\
\hline 250 & 8.5 & 2.8982 & 0.8558 & 0.03890 & $4.6745 \mathrm{E}-04$ & 0.012398 & 0.037704 & 64.0169 \\
\hline 300 & 8.5 & 2.8982 & 0.8558 & 0.03890 & $5.7186 \mathrm{E}-04$ & 0.013713 & 0.041702 & 35.1834 \\
\hline
\end{tabular}

As described previously in this section, the Park and Englezos measurements were similar to those of Gasteiger and Frederick. The major differences between the two sets of experiments are the absence of sulfides and the presence of chlorides in the Park and Engelos tests. The addition of chlorides caused the precipitation of a mixture of hydroxysodalite and natural (chloride) sodalite. Because sodium concentrations were significantly higher than chloride concentrations, about 3.5 molal for $\left[\mathrm{Na}^{+}\right]$versus approximately 0.3 molal for $\left[\mathrm{Cl}^{-}\right]$, most of the sodalite precipitates probably were hydroxysodalite. For this reason, this study treats the Park and Englezos tests as measurements of hydroxysodalite solubility.

Unfortunately, Park and Englezos did not publish tabulated data. This study uses data obtained from two graphs, Figures 2 and 5 in their paper. Figures B-15 and B-16 are reproductions of Figures 2 and 5, respectively. The measurements represented by these figures differ chiefly in the carbonate concentration. Figure B-15 shows measurements for high $\left[\mathrm{Na}_{2} \mathrm{CO}_{3}\right]$ and low $[\mathrm{NaOH}]$, while Figure B-16 depicts results for low $\left[\mathrm{Na}_{2} \mathrm{CO}_{3}\right]$ and high $[\mathrm{NaOH}]$. This study includes an analysis of formation constants for both sets of tests. However, the input to the modified database is restricted to the second set of tests run in more basic solutions. 


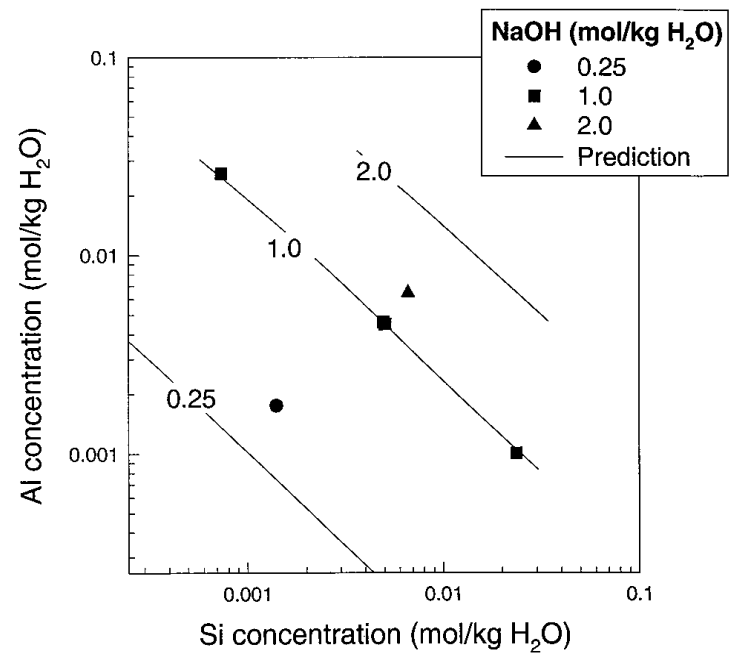

Figure B-15. Park and Englezos Solubility Measurements for 1.0 Molal Carbonate Solutions.

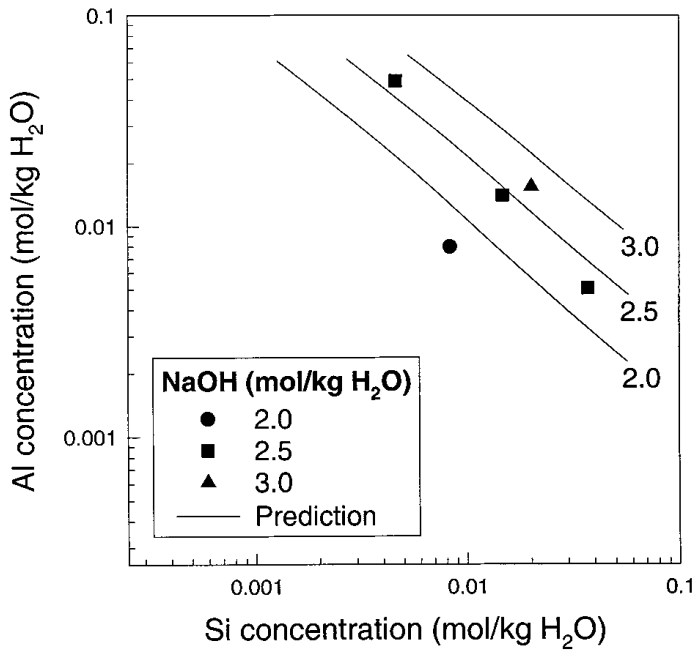

Figure B-16. Park and Englezos Solubility Measurements for 0.3 Molal Carbonate Solutions.

Table B-15 summarizes the calculations of the log formation constants for the measured concentrations and the extrapolation of the second set of tests to the typical evaporator sodium molality of 8.5 . One may note that there is much less variation in the calculated log formation constants than occurred for the Gasteiger and Frederick data. Due to the apparent consistency of these data, the analysis of the log formation constants for input to the modified database includes all five measurements at the low carbonate concentration.

Table B-15. Park and Engelos Solubility Data

\begin{tabular}{|c|c|c|c|c|c|c|c|}
\hline $\begin{array}{l}\mathbf{T} \\
\left({ }^{\circ} \mathbf{C}\right)\end{array}$ & $\begin{array}{l}{[\mathrm{Si}]} \\
\text { (molal) }\end{array}$ & $\begin{array}{l}{\left[\mathrm{Al}(\mathrm{OH})_{4}{ }^{\top}\right]} \\
\text { (molal) }\end{array}$ & $\begin{array}{l}{\left[\mathrm{Na}^{+}\right]} \\
\text {(molal) }\end{array}$ & $\begin{array}{l}{\left[\mathrm{Cl}^{-}\right]} \\
\text {(molal) }\end{array}$ & $\begin{array}{l}{\left[\mathrm{CO3}^{2-}\right]} \\
\text { (molal) }\end{array}$ & $\begin{array}{l}{\left[\mathrm{SO4}^{2-}\right]} \\
\text { (molal) }\end{array}$ & $\log \left(K_{f}\right)$ \\
\hline 95 & 0.00076 & 0.02589 & 3.453 & 0.37 & 1.0 & 0.1 & 76.0698 \\
\hline 95 & 0.00512 & 0.00443 & 3.473 & 0.325 & 1.0 & 0.1 & 76.1436 \\
\hline 95 & 0.02391 & 0.00099 & 3.504 & 0.28 & 1.0 & 0.1 & 76.0969 \\
\hline 95 & 0.00142 & 0.00174 & 2.718 & 0.325 & 1.0 & 0.1 & 73.8487 \\
\hline 95 & 0.00677 & 0.00638 & 4.475 & 0.325 & 1.0 & 0.1 & 76.1178 \\
\hline 95 & 0.00465 & 0.04845 & 3.403 & 0.34 & 0.3 & 0.1 & 78.6156 \\
\hline 95 & 0.01494 & 0.01383 & 3.452 & 0.25 & 0.3 & 0.1 & 78.1184 \\
\hline 95 & 0.03721 & 0.00503 & 3.484 & 0.16 & 0.3 & 0.1 & 77.7106 \\
\hline 95 & 0.00836 & 0.00800 & 2.944 & 0.25 & 0.3 & 0.1 & 75.5208 \\
\hline 95 & 0.02037 & 0.01518 & 3.955 & 0.25 & 0.3 & 0.1 & 78.9202 \\
\hline
\end{tabular}

Extrapolated to $\left[\mathrm{Na}^{+}\right]=8.5$ molal and Used in Solubility Model.

\begin{tabular}{|c|c|c|c|c|c|c|c|}
\hline $\begin{array}{l}\mathbf{T} \\
\left({ }^{\circ} \mathbf{C}\right)\end{array}$ & $\begin{array}{l}{[\mathrm{Si}]} \\
\text { (molal) }\end{array}$ & $\begin{array}{l}{\left[\mathrm{Al}(\mathrm{OH})_{4}{ }^{-}\right]} \\
(\text {molal })\end{array}$ & $\begin{array}{l}{\left[\mathrm{Na}^{+}\right]} \\
\text {(molal) }\end{array}$ & $\begin{array}{l}{\left[\mathrm{Cl}^{-}\right]} \\
\text {(molal) }\end{array}$ & $\begin{array}{l}{\left[\mathrm{CO3}^{2-}\right]} \\
\text { (molal) }\end{array}$ & $\begin{array}{l}{\left[\mathrm{SO4}^{2-}\right]} \\
\text { (molal) }\end{array}$ & $\begin{array}{l}\mathbf{K}_{\text {sp }} \\
\left(\text { molal }^{2}\right)\end{array}$ \\
\hline 95 & 0.01163 & 0.12102 & 8.5 & 0.8492 & 0.7493 & 0.2498 & 0.001407 \\
\hline 95 & 0.03679 & 0.03405 & 8.5 & 0.6156 & 0.7387 & 0.2462 & 0.001253 \\
\hline 95 & 0.09078 & 0.01228 & 8.5 & 0.3903 & 0.7318 & 0.2439 & 0.001114 \\
\hline 95 & 0.02415 & 0.02311 & 8.5 & 0.7218 & 0.8661 & 0.2887 & 0.000558 \\
\hline 95 & 0.04377 & 0.03263 & 8.5 & 0.5373 & 0.6447 & 0.2149 & 0.001428 \\
\hline
\end{tabular}


The calculated hydroxysodalite solubility at $95^{\circ} \mathrm{C}$ was much closer to the Zeolite-A solubility than to the $\mathrm{NAS}_{\text {gel }}$ solubility. Therefore, the extrapolation of the solubility product with respect to temperature uses the Arrhenius factor for Zeolite-A. The relatively close agreement between the solubilities of hydroxysodalite and Zeolite-A suggest, that the Zeolite-A Arrhenius factor can be used for hydroxysodalite to extrapolate hydroxysodalite solubilities from $95^{\circ} \mathrm{C}$ to other temperatures. This was done.

The extrapolation procedure is the same one used for the Gasteiger and Frederick data. As before, the extrapolation is based on the average sodium, chloride, carbonate, and sulfate concentrations for the five tests included in the analysis. The averaging procedure for silicate and aluminate concentrations uses the average of the log of the solubility product, with the Si:Al ratio equal to the average ratio for the five tests. Table B-16 lists the results of the calculation of the log formation constants for the modified database.

Table B-16. Extrapolated Solubilities and Formation Constants for Hydroxysodalite at $\left[\mathrm{Na}^{+}\right]=8.5$ molal.

\begin{tabular}{|c|c|c|c|c|c|c|c|c|}
\hline $\begin{array}{l}\mathbf{T} \\
\left({ }^{\circ} \mathbf{C}\right)\end{array}$ & $\begin{array}{l}K_{s p} \\
\left(\text { molal }^{2}\right)\end{array}$ & $\begin{array}{l}{[\mathrm{Si}]} \\
\text { (molal) }\end{array}$ & $\begin{array}{l}{\left[\mathrm{Al}(\mathrm{OH})_{4}{ }^{\top}\right]} \\
(\text { molal })\end{array}$ & $\begin{array}{l}{\left[\mathrm{Na}^{+}\right]} \\
(\text {molal })\end{array}$ & $\begin{array}{l}{\left[\mathrm{Cl}^{-}\right]} \\
\text {(molal) }\end{array}$ & $\begin{array}{l}{\left[\mathrm{CO3}^{2-}\right]} \\
\text { (molal) }\end{array}$ & $\begin{array}{l}{\left[\mathrm{SO4}^{2-}\right]} \\
\text { (molal) }\end{array}$ & $\log \left(K_{f}\right)$ \\
\hline 0 & 0.000176 & 0.012781 & 0.013767 & 8.5 & 0.622813 & 0.746121 & 0.248707 & 119.1794 \\
\hline 25 & 0.000324 & 0.017344 & 0.018682 & 8.5 & 0.622813 & 0.746121 & 0.248707 & 103.9755 \\
\hline 60 & 0.000653 & 0.024622 & 0.026522 & 8.5 & 0.622813 & 0.746121 & 0.248707 & 89.3155 \\
\hline 100 & 0.001238 & 0.033908 & 0.036524 & 8.5 & 0.622813 & 0.746121 & 0.248707 & 82.2676 \\
\hline 150 & 0.002325 & 0.046459 & 0.050043 & 8.5 & 0.622813 & 0.746121 & 0.248707 & 75.4103 \\
\hline 200 & 0.003821 & 0.059557 & 0.064151 & 8.5 & 0.622813 & 0.746121 & 0.248707 & 66.3211 \\
\hline 250 & 0.005710 & 0.072807 & 0.078424 & 8.5 & 0.622813 & 0.746121 & 0.248707 & 54.7385 \\
\hline 300 & 0.007955 & 0.085940 & 0.092570 & 8.5 & 0.622813 & 0.746121 & 0.248707 & 40.3259 \\
\hline
\end{tabular}


WSRC-TR-2000-00293, Rev. 1

\section{REFERENCES FOR APPENDIX B}

1 V. I. Babushkin, G. M. Matveyev, and O. P. Mchedlov-Petrossyan, Thermodynamics of Silicates,.Springer-Verlag, Berlin (1985), pp. 276-281, 432.

2 C. F. Baes, Jr., and R. E. Mesmer, The Hydrolysis of Cations, John Wiley and Sons, New York (1976), pp. 337-342.

3 J. Sefcik and A.V. McCormick, "Thermochemistry of Aqueous Silicate Solution Precursors to Ceramics," Ceramics processing, 43, No.11A, 2773-2784 (1997).

4 J. Bjerrum, G. Schwarzenbach, and L.G. Sillen, "Stability Constants of Metal-ion Complexes with Solubility Products of Inorganic Substances," The Chemical Society, London (1958).

5 G. B. Alexander, W. M. Heston, and R. K. Iler, "The Solubility of Amorphous Silica in Water,’ J. Phys. Chem., 58, June, 1954, 453-455.

6 R. K. Iler, The Colloid Chemistry of Silica and Silicates, Cornell University Press, Ithaca, NY (1955), p. 12.

7 D. A. Reynolds and D. L. Herting, "Solubilities of Sodium Nitrate, Sodium Nitrite, and Sodium Aluminate in Simulated Nuclear Waste," Rockwell Hanford Report RHO-RE-ST-14P, September, 1984.

8 A.S. Russell, J.D. Edwards, and C.S. Taylor, "Solubility and Density of Hydrated Aluminas in NaOH Solutions," J. of Metals, p.1123-1128 (October, 1955).

9 D.J. Wesolowski, “Aluminum Speciation and Equilibria in Aqueous Solution, I. The Solubility of Gibbsite in the System Na-K-Cl-OH-Al(OH)4 from 0 to 100 'C,' Geochemica Cosmochemica Acta, 56, 1065-1091 (1992).

10 T. Ejaz A.G. Jones and P. Graham, "Solubility of Zeolite-A and Its Amorphous Precursor Under Synthesis Conditions,” J. Chem. Eng. Data, 44, 574-576 (1999).

11 Personal communication

12 H. Park and P. Englezos, "Thermodynamic Modeling of Sodium Aluminosilicate Formation in Aqueous Alkaline Solutions," Ind. Eng. Chem. Res., 1999, 38, 49594965. 


\section{Appendix C}

\section{Validation of Activity Diagram Calculations in the Complex Na-N-Si-Al-U- $\mathrm{H}_{2} \mathrm{O}$ System}

Two data sets were available for validation of the GWB code in the complex Na-N-Si-Al$\mathrm{U}-\mathrm{H}_{2} \mathrm{O}$ system. The first of these was the analysis of the SRS M-Area wastes from 1987 when the M-Area tanks were well agitated. The second was data from a neutralization study performed by Robert Pierce of SRTC where caustic additions were sequentially made to a highly acidic concentrated uranyl nitrate solution in preparation for neutralization of the uranyl nitrate solutions being used to clean the SRS 2H Evaporator. The M-Area data were generated for solutions at $25^{\circ} \mathrm{C}$, while the Pierce data were generated at an elevated temperature but were analyzed at $25^{\circ} \mathrm{C}$. Both sets of data are modeled at $25^{\circ} \mathrm{C}$. In addition, to gauge the effect of temperature on phase transitions, the Pierce data is modeled at $70^{\circ} \mathrm{C}$. The following tables summarize the measured concentrations for the M-Area tanks and for Pierce's neutralization test in molar (gmoles/L) and molal (gmoles/ $\mathrm{kg} \mathrm{H}_{2} \mathrm{O}$ ) units.

\section{Table C.1. Analytic Molar Concentrations for M-Area Tanks ${ }^{1}$ and Pierce Neutralization Experiment ${ }^{2}$}

\begin{tabular}{|c|c|c|c|c|c|c|c|c|}
\hline $\begin{array}{c}\text { Tank } \\
\text { No. }\end{array}$ & $\mathbf{O H}^{-}(\mathbf{M})^{*}$ & $\begin{array}{c}\mathbf{S i} \\
(\mathbf{M})\end{array}$ & $\begin{array}{c}\mathbf{A l} \\
(\mathbf{M})\end{array}$ & $\begin{array}{c}\mathbf{N O}_{3}^{-} \\
(\mathbf{M})\end{array}$ & $\begin{array}{c}\mathbf{C O}_{3}^{2-} \\
(\mathbf{M})^{*}\end{array}$ & $\begin{array}{c}\mathbf{S O}_{4}^{2-} \\
(\mathbf{M})\end{array}$ & $\begin{array}{c}\mathbf{N a} \\
(\mathbf{M})\end{array}$ & $\begin{array}{c}\mathbf{U} \\
(\mathbf{M})\end{array}$ \\
\hline & & & & & & & & \\
\hline Tank 6 & 0.1820 & 0.0102 & 0.1323 & 0.9536 & 0.0895 & 0 & 1.4698 & $2.50 \times 10^{-3}$ \\
\hline Tank 8 & 0.1273 & 0.0002 & 0.1021 & 1.2280 & 0.0550 & 0 & 1.5681 & $3.36 \times 10^{-4}$ \\
\hline Pierce & $0.94 \times 10^{-11}$ & 0 & 0 & 3.2 & $0.98 \times 10^{-5}$ & 0 & 1 & 1.2 \\
\hline
\end{tabular}

*Tank 6 and Tank $8 \mathrm{OH}^{-}$concentrations are estimated from charge balances. The $\mathrm{OH}^{-}$ and $\mathrm{CO}_{3}{ }^{2-}$ concentrations for the Pierce experiment are calculated using REACT, based on a charge balance and saturation with $\mathrm{CO}_{2}$, respectively.

\section{Table C.2. Molal Concentrations for M-Area Tanks and Pierce Neutralization Experiment}

\begin{tabular}{|c|c|c|c|c|c|c|c|c|c|}
\hline $\begin{array}{c}\text { Tank } \\
\text { No. }\end{array}$ & $\begin{array}{c}\text { Temp. } \\
\left({ }^{\circ} \mathbf{C}\right)\end{array}$ & $\begin{array}{c}\mathbf{O H}^{-} \\
(\mathbf{m})^{*}\end{array}$ & $\begin{array}{c}\mathbf{S i} \\
(\mathbf{m})\end{array}$ & $\begin{array}{c}\mathbf{A l} \\
(\mathbf{m})\end{array}$ & $\begin{array}{c}\mathbf{N O}_{\mathbf{3}}^{-} \\
(\mathbf{m})\end{array}$ & $\begin{array}{c}\mathbf{C O}_{3}^{2-} \\
(\mathbf{m})^{*}\end{array}$ & $\begin{array}{c}\mathbf{S O}_{\mathbf{4}}^{2-} \\
(\mathbf{m})\end{array}$ & $\begin{array}{c}\mathbf{N a} \\
(\mathbf{m})\end{array}$ & $\begin{array}{c}\mathbf{U} \\
(\mathbf{m})\end{array}$ \\
\hline & & & & & & & & & \\
\hline Tank 6 & 25 & 0.1887 & 0.0106 & 0.1372 & 0.9889 & 0.0928 & 0 & 1.5242 & $2.60 \times 10^{-3}$ \\
\hline Tank 8 & 25 & 0.1302 & 0.0002 & 0.1045 & 1.2562 & 0.0563 & 0 & 1.6041 & $3.44 \times 10^{-4}$ \\
\hline Pierce & $25 / 70$ & $1.07 \times 10^{-11}$ & 0 & 0 & 3.6471 & $1.12 \times 10^{-5}$ & 0 & 1.1397 & 1.3677 \\
\hline
\end{tabular}

*Tank 6 and Tank $8 \mathrm{OH}^{-}$concentrations are estimated from charge balances. The $\mathrm{OH}^{-}$ and $\mathrm{CO}_{3}{ }^{2-}$ concentrations for the Pierce experiment are calculated using REACT, based on a charge balance and saturation with $\mathrm{CO}_{2}$, respectively.

The REACT code was run using the M-Area supernate analyses from M-Area Tanks 6 and 8. All mineral formation was suppressed as it was done for the SRS Evaporator 
modeling. The ionic strength of these samples was $\sim 1.3$ at $\mathrm{pH}$ values of 11.90 for Tank 8 and 12.25 for Tank 6 . The REACT code predicted that the solutions were supersaturated with respect to Zeolite- $\mathrm{A}, \mathrm{Na}_{2} \mathrm{U}_{2} \mathrm{O}_{7}$ (sodium diuranate), and $\mathrm{Al}(\mathrm{OH})_{3}$ (gibbsite). The phases identified to have formed in the sludge (after the supernate was allowed to settle) were Zeolite-A, $\mathrm{Na}_{2} \mathrm{U}_{2} \mathrm{O}_{7}$, and $\mathrm{Al}(\mathrm{OH})_{3}$. These phases were identified by $\mathrm{x}$-ray diffraction. ${ }^{1}$ Figures $\mathrm{C}-1$ and $\mathrm{C}-2$ demonstrate that the $\mathrm{M}$-area supernates were in the stability field of gibbsite, $\mathrm{Al}(\mathrm{OH})_{3}$, when they were agitated. After agitation ceased, e.g. at long residence times, the tanks became saturated with respect to Zeolite-A as shown by Figures C-3 and C-4. Figures C-5 and C-6 demonstrate that the M-Area tanks were simultaneously in the stability field of $\mathrm{Na}_{2} \mathrm{U}_{2} \mathrm{O}_{7}$ formation, which was confirmed by $\mathrm{x}$-ray diffraction analysis of this phase in the precipitated sludge. ${ }^{1}$

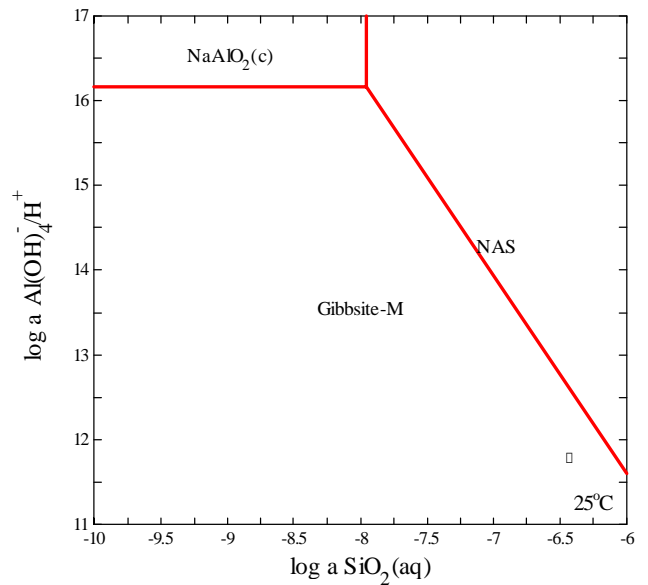

Figure C-1. Activity diagram for MArea Tank 6 showing that the supernate was in the stability field of gibbsite when the tanks were well mixed/agitated.

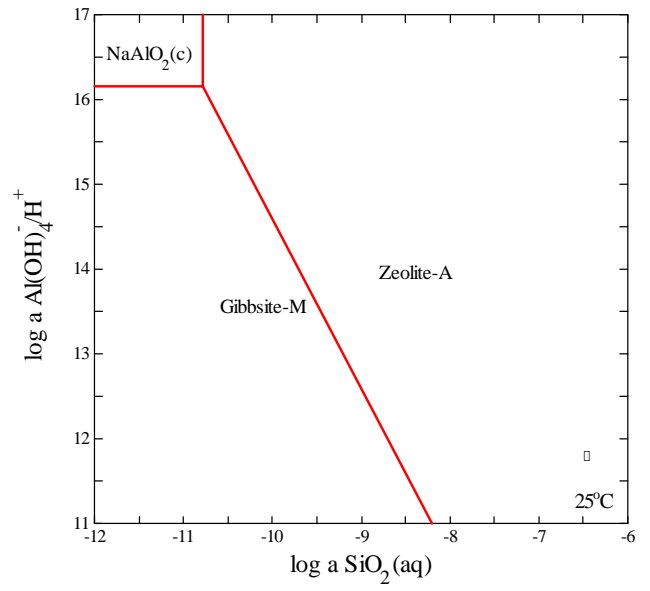

Figure C-3. Activity diagram for M-Area Tank 6 showing that the sludge was in the stability field of Zeolite-A after agitation was stopped and the solids were allowed to settle.

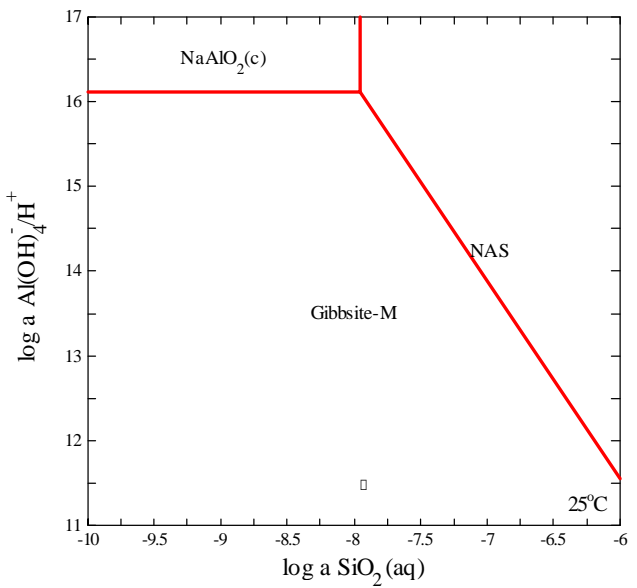

Figure C-2 Activity diagram for M-Area Tank 8 showing that the supernate was in the stability field of gibbsite when the tanks were well mixed/agitated.

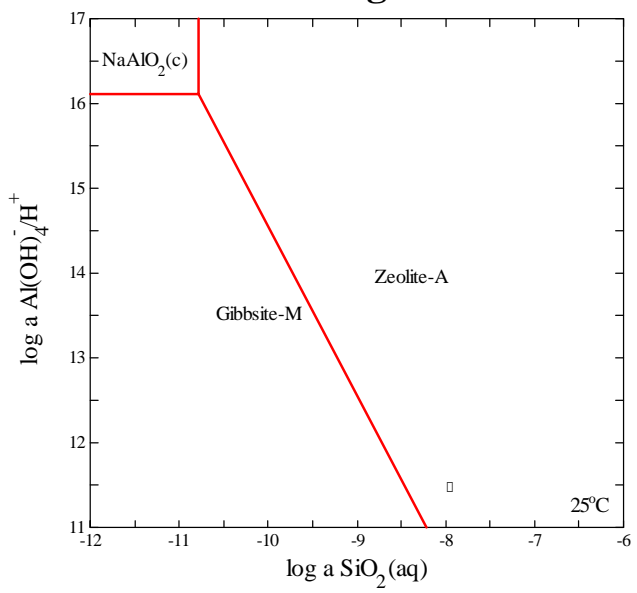

Figure C-4. Activity diagram for M-Area Tank 6 showing that the sludge was in the stability field of Zeolite-A after agitation was stopped and the solids were allowed to settle. 


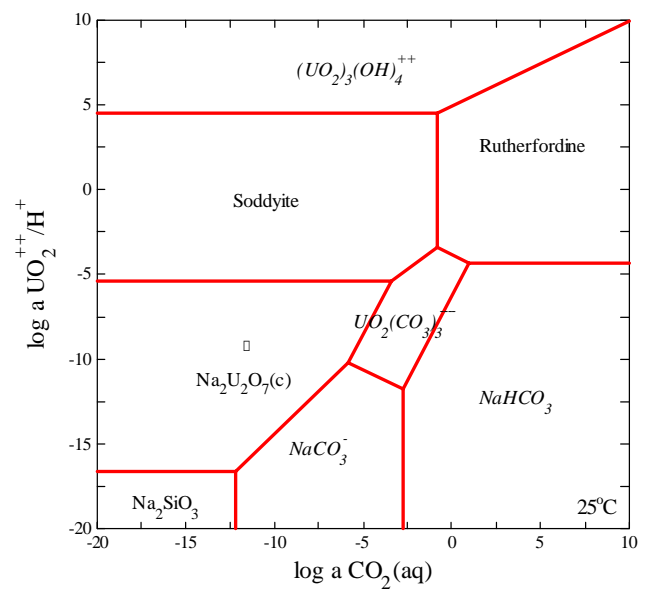

Figure C-5. Activity diagram for M-Area Tank 6 showing that the supernates were in equilibrium with respect to $\mathrm{Na}_{2} \mathrm{U}_{2} \mathrm{O}_{7}$ when they were well mixed/agitated. This is the phase that precipitated in the sludge when the supernates were no longer agitated.

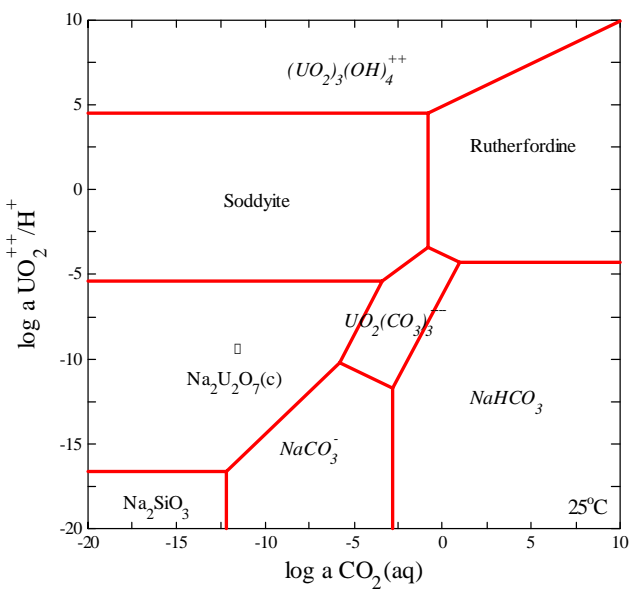

Figure C-6. Activity diagram for MArea Tank 6 showing that the supernates were in equilibrium with respect to $\mathrm{Na}_{2} \mathrm{U}_{2} \mathrm{O}_{7}$ when they were well mixed/agitated. This is the phase that precipitated in the sludge when the supernates were no longer agitated.

The second set of validation data was from a study of caustic neutralization of a highly acidic concentrated uranyl nitrate solution by R. A. Pierce. ${ }^{2}$ For modeling, a nitrogen fugacity of 0.8 and a $\mathrm{CO}_{2}$ fugacity of $10^{-3.5}$ (saturated with $\mathrm{CO}_{2}$ ) were assumed. Pierce's solution remained acidic after he started the neutralization, but a precipitate formed that was analyzed by $\mathrm{x}$-ray diffraction to be becquerelite (JCPDS pattern \#29-0389).

Becquerelite is a structural isomer of schoepite $\left(\mathrm{UO}_{2} \cdot 2 \mathrm{H}_{2} \mathrm{O}\right)^{3}$ and would appear as this phase during $\mathrm{X}$-ray diffraction analysis (see Figure $\mathrm{C}-7$ ). It is, therefore, confirmatory that Pierce's data falls in the stability field of schoepite at both $25^{\circ} \mathrm{C}$ and $70^{\circ} \mathrm{C}$ (Figures C-8 and C-9). Both of these independent studies validate that GWB is calculating the activity diagrams and the reactions in this complex system correctly. 
WSRC-TR-2000-00293, Rev. 1

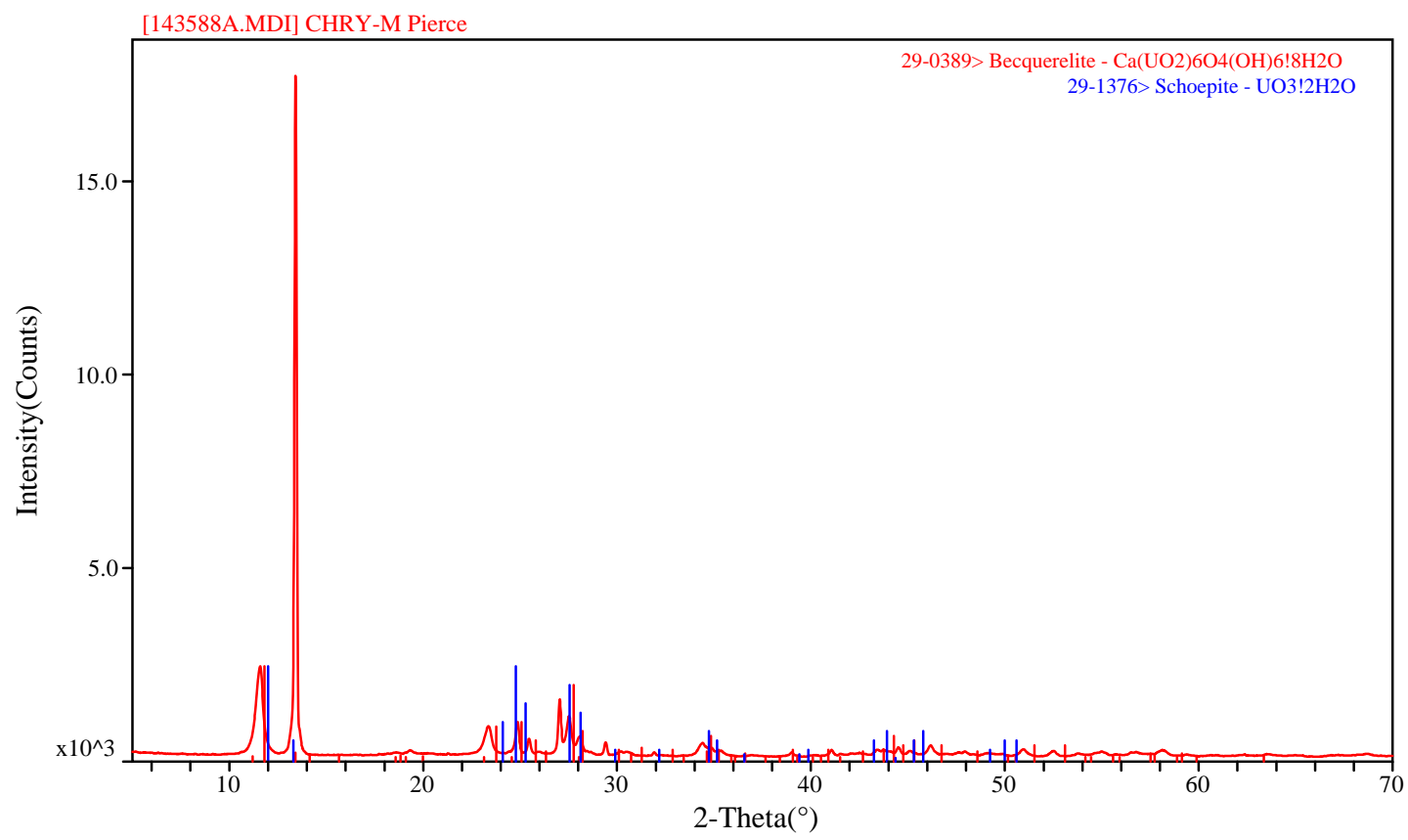

Figure C-7. X-ray diffraction pattern of precipitate from Pierce's neutralization experiment showing the identification of becquelerite/schoepite.

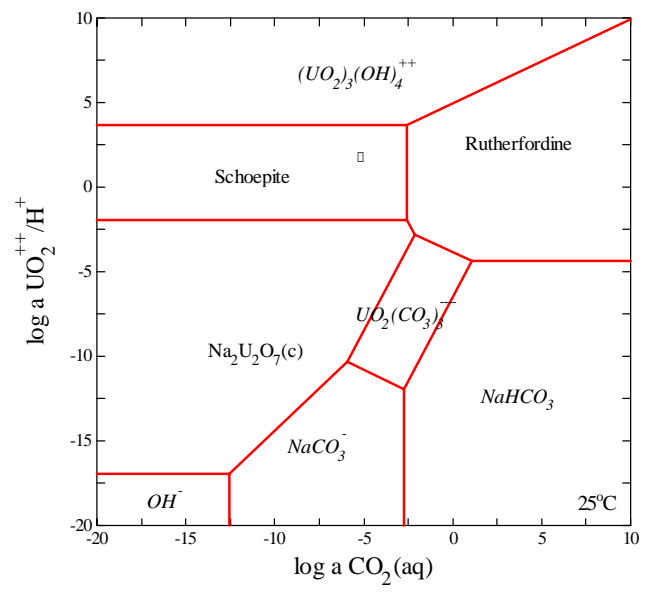

Figure C-8. Activity diagram for Pierce neutralization experiment at $25^{\circ} \mathrm{C}$ demonstrating that the solutions were in the stability field of schoepite.

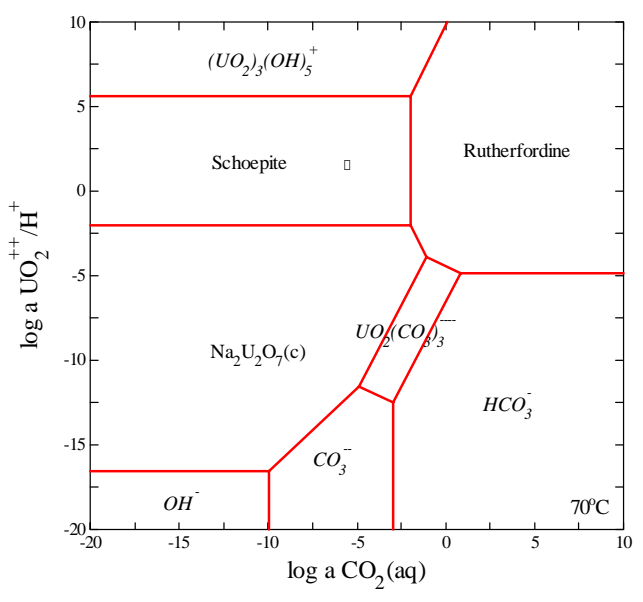

Figure C-9. Activity diagram for Pierce neutralization experiment at $70^{\circ} \mathrm{C}$ demonstrating that the solutions were in the stability field of schoepite. 


\section{REFERENCES FOR APPENDIX C}

1 C. M. Jantzen, "Vitrification of M-Area Mixed (Hazardous and Radioactive) Wastes: I. Sludge and Supernate Characterization,” WSRC-TR-94-0234 (in press). Earlier report with fewer tank analyses published as DPST-89-351 (March 1, 1989).

2 R.A. Pierce, WSRC-NB-2000-00054 (June 14, 2000).

3 E.S. Dana, “A Textbook of Mineralogy,” John Wiley \& Sons, Inc., New York, 851pp. (1932) 
WSRC-TR-2000-00293, Rev. 1

\section{Appendix D}

\section{Mass Balance of Evaporator Wall Vs. Evaporator Pot Deposits}

The evaporator wall and evaporator pot deposits had been analyzed by Wilmarth. ${ }^{1,2}$ For each sample, the amount of elemental $U$ in wt $\%$ was divided by the atomic weight of $U$ and divided by 2 (the number of $U$ atoms in sodium diuranate) in order to calculate how many moles $\mathrm{Na}_{2} \mathrm{U}_{2} \mathrm{O}_{7}$ could be formed with this amount of uranium. The number of moles of $\mathrm{Na}_{2} \mathrm{U}_{2} \mathrm{O}_{7}$ that could form was then multiplied by the molecular wt of $\mathrm{Na}_{2} \mathrm{U}_{2} \mathrm{O}_{7}$ in order to determine the wt\%. A corresponding amount of $\mathrm{Na}$ in $\mathrm{wt} \%$ was removed from the total $\mathrm{Na}$ available.

The nitrated sodalite was calculated by assuming that all of the silica formed this phase. Ideally a nitrate analysis would have been used to calculate the wt $\%$ nitrated sodalite but no nitrate analytes were available. The wt $\% \mathrm{Si}$ was divided by the atomic wt of $\mathrm{Si}$ and divided by 6 (the number of Si atoms in the nitrated sodalite) in order to calculate how many moles sodalite could be formed with this amount of silica. The moles of Si were then multiplied by the molecular wt of sodalite in order to calcualte the wt $\%$ sodalite that was in the deposits. This should have consumed all of the Si but as a calculation check, the excess or deficit $\mathrm{SiO}_{2}$ was always calculated. It was always a very small number due to rounding errors.

The $\mathrm{Al}(\mathrm{OH})_{3}$ was calculated by depleting the total inventory of elemental $\mathrm{Al}$ by the amount assigned to the nitrated sodalite. The moles of unassigned $\mathrm{Al}$ were calculated and the number of moles multiplied by the atomic weight of $\mathrm{Al}(\mathrm{OH})_{3}$.

Lastly, the excess $\mathrm{Na}$ over that used to speciate $\mathrm{Na}_{2} \mathrm{U}_{2} \mathrm{O}_{7}$ and nitrated sodalite was calculated. The moles of unassigned $\mathrm{Na}$ were calculated and the number of moles multiplied by the atomic weight of $\mathrm{NaOH}$. 
WSRC-TR-2000-00293, Rev. 1

\begin{tabular}{|c|c|c|}
\hline $\begin{array}{l}\text { Line } \\
\#\end{array}$ & $\begin{array}{l}\text { COLUMN A } \\
\text { (ELEMENT) }\end{array}$ & COLUMN B (ELEMENT WT\%) \\
\hline 1 & $\mathrm{Al}$ & 6.04 \\
\hline 2 & $\mathrm{Fe}$ & 0.48 \\
\hline 3 & $\mathrm{Na}$ & 14.37 \\
\hline 4 & $\mathrm{Si}$ & 6.04 \\
\hline 5 & $\mathrm{U}$ & 6.81 \\
\hline 6 & \multicolumn{2}{|l|}{ MASS BALANCE (wt\%) } \\
\hline 7 & & \\
\hline 8 & $\mathrm{Al}(\mathrm{OH})_{3}$ & $=(((((\mathrm{B} 1 / 26.98)-((\mathrm{B} 12 / 6) / 1280.25 / 26.98))) * 78))$ \\
\hline 9 & $\mathrm{NaOH}$ & $\begin{array}{l}=((\mathrm{B} 3 / 23)-((\mathrm{B} 12 / 8) / 1280.25) / 23)- \\
((\mathrm{B} 11 / 2) / 634.06 / 23) * 40\end{array}$ \\
\hline 10 & $\mathrm{SiO}_{2}$ (excess or deficit) & $\begin{array}{l}=((((\mathrm{B} 4 / 28.09)- \\
(\mathrm{B} 12 / 6)) /(1280.25) / 28.09) *(60.0848))\end{array}$ \\
\hline 11 & $\mathrm{Na}_{2} \mathrm{U}_{2} \mathrm{O}_{7}$ & $=((\mathrm{B} 5 / 238.029) / 2)^{*} 634.06$ \\
\hline 12 & $\mathrm{Na}_{8} \mathrm{Al}_{6} \mathrm{Si}_{6} \mathrm{O}_{24}\left(\mathrm{NO}_{3}\right)_{2} \bullet 4 \mathrm{H}_{2} \mathrm{O}$ & $=(((\mathrm{B} 4 / 28.08)) / 6) *(1280.25)$ \\
\hline 13 & & \\
\hline 14 & SUM & $=\mathrm{SUM}(\mathrm{B} 8: \mathrm{B} 12)$ \\
\hline
\end{tabular}

\section{REFERENCES FOR APPENDIX D}

1 W. R. Wilmarth, C. J. Coleman, A. R. Jurgensen, W. M. Smith, J. C. Hart, W. T. Boyce, D. Missimer, C. M. Conley, "Characterization and Dissolution Studies of Samples from the 242-16H Evaporator," WSRC-TR-2000-00038, Rev. 0 (January 31, 2000).

2 W. R. Wilmarth, S. D. Fink, D. T. Hobbs, M. S. Hay, “Characterization and Dissolution Studies of Samples from the 242-16H Evaporator Gravity Drain Line," WSRC-TR-97-00326, Rev.0 (October 16, 1997). 